\title{
Analysis of PG\&E's \\ Residential End-Use Metered Data \\ to Improve Electricity \\ Demand Forecasts
}

Joseph H. Eto and Mithra M. Moezzi

Energy \& Environment Division

Lawrence Berkeley Laboratory

University of California

Berkeley, CA 94720

June 1992

The work described in this report was funded by the Assistant Secretary for Conservation and Renewable Energy, Office of Utility Technologies, Office of Energy Management Division of the U.S. Department of Energy under Contract No. DE-AC03-76SF00098. 


\begin{abstract}
It is generally acknowledged that improvements to end-use load shape and peak demand forecasts for electricity are limited primarily by the absence of reliable end-use data. In this report, we analyze recent end-use metered data collected by the Pacific Gas and Electric Company from more than 700 residential customers to develop new inputs for the load shape and peak demand electricity forecasting models used by the Pacific Gas and Electric Company and the California Energy Commission. Hourly load shapes are normalized to facilitate separate accounting (by the models) of annual energy use and the distribution of that energy use over the hours of the day. Cooling electricity consumption by central air-conditioning is represented analytically as a function of climate. Limited analysis of annual energy use, including unit energy consumption (UEC), and of the allocation of energy use to seasons and system peak days, is also presented.
\end{abstract}


Abstract $\ldots \ldots \ldots \ldots \ldots \ldots \ldots \ldots \ldots \ldots \ldots \ldots \ldots \ldots \ldots$

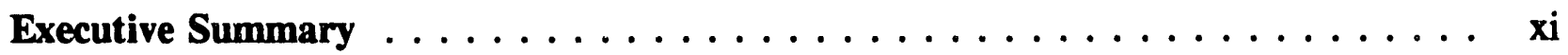

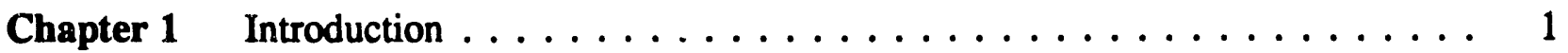

Chapter 2 PG\&E and CEC Load Shape and Peak Demand

Forecasting Models ...................... 3

Chapter 3 The PG\&E Appliance Metering Project $\ldots \ldots \ldots \ldots \ldots \ldots$

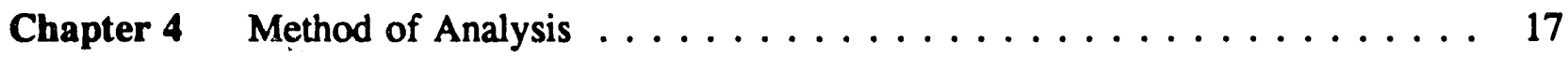

Chapter 5 Cooling Electricity Use Analysis

for CEC Peak Demand Model ... . . . . . . . . . . . . . 21

Chapter 6 Cooling Electricity Use Analysis for PG\&E

Load Shape Model ....................... 31

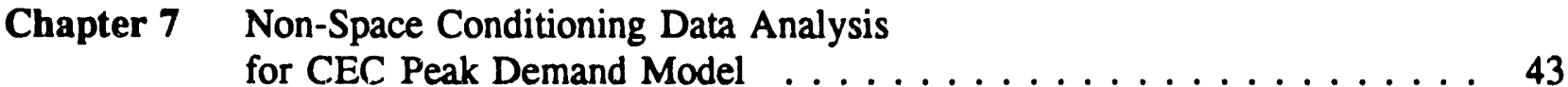

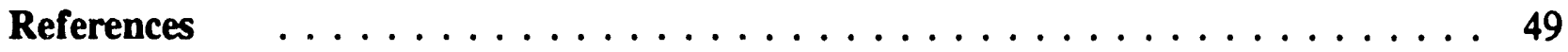

Appendix A Data Handling Conventions and Review $\ldots \ldots \ldots \ldots$

Appendix B Data Tables for Chapter $3 \ldots \ldots \ldots \ldots$

Appendix C Data Tables for Chapter $5 \ldots \ldots \ldots \ldots$

Appendix D Data Tables for Chapter $6 \ldots \ldots \ldots$. . . . . . . . . . . 105

Appendix E Data Tables for Chapter $7 \ldots \ldots \ldots \ldots \ldots$

Appendix $\mathbf{F}$ Exploratory Analysis for CEC Space

Conditioning THI-Matrix . . . . . . . . . . . . . . . . 139 
3-1 Number of Appliances Metered $\ldots \ldots \ldots \ldots \ldots \ldots$

3-2 Number of Central and Room Air Conditioners Metered by CEC Region and PG\&E Zone . . . . . . . . . . . . . . . 9

3-3 Annual UEC for Central Air Conditioning, CEC Regions . . . . . . . . 10

3-4 Annual UEC for Room Air Conditioning, CEC Regions . . . . . . . . . . 11

3-5 Annual UEC for Central Air Conditioning, PG\&E Zones . . . . . . . . 12

3-6 Annual UEC for Room Air Conditioning, PG\&E Zones . . . . . . . . . . 13

3-7 Annual UEC for Non-Conditioning Appliances . . . . . . . . . . . . . 14

3-8 Comparison of 1989 UECs Assumed in PG\&E and CEC Forecasts and UECs Calculated by LBL . . . . . . . . . . . . . . . 15

5-1 Summary of Measures from Comparison of Daily Backcast Load Shape to Sample CEC Region $2 \ldots \ldots$. . . . . . . . . . . . . . . . . . 27

5-2 Summary of Measures From Comparison of Daily Backcast Load Shape to Sample CEC Region $3 \ldots \ldots \ldots \ldots \ldots$

5-3 Summary of Measures From Comparison of Daily Backcast Load Shape to Sample CEC Region 4 . . . . . . . . . . . . . . . . . . . . . . . . . 29

6-1 LBL Coefficient Estimates for PG\&E Weather Response Functions . . . . . . . . . . . . . . . . . . . . . . 34

6-2 PG\&E Cooling Load Bins by Zone for Ranges of

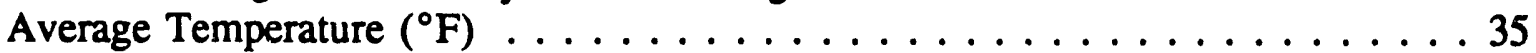

7-1 Seasonal Allocation Factors Non-Conditioning End Uses . . . . . . . . . 45

7-2 Energy Use Ratios Non-Conditioning End Uses . . . . . . . . . . . . 45 
4-1 Illustration of Measures Used for Load Shape Comparisons . . . . . . . . . . . . 19

5-1 Raw Time-Temperature Matrix for Central Conditioning Based on 1985-1989 AMP Data from all Regions . . . . . . . . . . . . . . 25

5-2 Smoothed Time-Temperature Matrix for Central Conditioning Based on 1985-1989 AMP Data from all Regions . . . . . . . . . . . . . . . . 26

6-1 Central AC Load Shapes for PG\&E Average Temperature Bins Zone R Weekdays . . . . . . . . . . . . . . . . . . . . . . . 36

6-2 Central AC Load Shapes for PG\&E Average Temperature Bins Zone R Weekends . . . . . . . . . . . . . . . . . . . . . . . . 37

6-3 Central AC Load Shapes for PG\&E Average Temperature Bins Zone S Weekday . . . . . . . . . . . . . . . . . . . . . . . 38

6-4 Central AC Load Shapes for PG\&E Average Temperature Bins Zone S Weekend . . . . . . . . . . . . . . . . . . . . . . . . 39

6-5 Central AC Load Shapes for PG\&E Average Temperature Bins Zone X Weekday . . . . . . . . . . . . . . . . . . . . . . . . . . . 40

6-6 Central AC Load Shapes for PG\&E Average Temperature Bins Zone X Weekend . . . . . . . . . . . . . . . . . . . . . . . 41

6-7 Cooling Load Shape for Zone R 87.5-100 ${ }^{\circ} \mathrm{F}$ Weekday Bin with $95 \%$ CI on Hourly Means . . . . . . . . . . . . . . . . . . . . . . 42

6-8 Cooling Load Shape for Zone R $87.5-100^{\circ} \mathrm{F}$ Weekend Bin with $95 \%$ CI on Hourly Means . . . . . . . . . . . . . . . . . . . . . . 42

7-1 Average Load Profiles by Season and Day Type for Clothes Dryer . . . . . . . . . . . . . . . . . . . . . . . . 46

7-2 Average Load Profiles by Season and Day Type

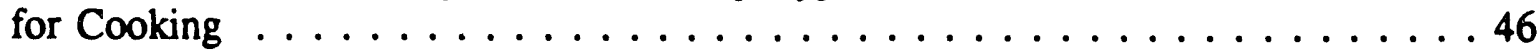

7-3 Average Load Profiles by Season and Day Type for Kitchen Circuit . . . . . . . . . . . . . . . . . . . . . 47

7-4 Average Load Profiles by Season and Day Type for Refrigerator . . . . . . . . . . . . . . . . . . . . . . . 47

7-5 Average Load Profiles by Season and Day Type for Water Heater . . . . . . . . . . . . . . . . . . . . . . . 48 


\section{Executive Summary}

Forecasting electricity demand in an era of integrated resource planning requires detailed information on the end-use energy services provided by electricity. End-use detail on the hourly pattern of electricity use is especially important because electricity cannot be readily stored. As a result, electricity resource planning decisions (on both sides of the customer's meter) are strongly influenced by the expected timing and magnitude of system peak demands.

For this reason, the Pacific Gas \& Electric Company (PG\&E) and the California Energy Commission (CEC) rely upon a host of sophisticated end-use forecasting tools. However, both will agree that it is often differences in data and assumptions, rather than models, that lead to differences in forecasts. It is generally acknowledged that the empirical basis for the models is the weakest link in their forecasting capabilities. With respect to the peak demand forecasting models, the load shape data inputs are, for the most part, unverified, consisting of either engineering load simulations, borrowed end-use metered data, or class load studies. Extensive calibration efforts are often required to backcast historic system loads accurately.

The importance of more accurate peak demand and load shape forecasts, as well as the need to betier assess demand-side resource opportunities, has led California utilities to initiate major enduse metering projects. These projects are extremely expensive and require years to complete. Data from the projects have only recently been incorporated into limited aspects of the peak demand and load shape forecasts by California utilities.

The current project represents a unique collaborative research effort by PG\&E and CEC to develop a common set of residential sector end-use load shape forecasting inputs from the enduse metered data collected by PG\&E from over 700 customers. While features of the forecasting models and approaches used by PG\&E and CEC precluded development of an identical set of inputs for each, the application of consistent analytical approaches to a common data set ensured consistency of the model-specific results.

The motivation for this collaboration is the recognition that, within the Common Forecasting Methodology process, explicit agreement on the factual basis for competing forecasts offers significant benefits. First, it focuses subsequent discussion on issues where there are genuine differences of opinion, rather than on issues where there are simply different data sources, both of which require substantial staff resources to understand. Second, it provides opportunities for technical discussions between utility and CEC staff outside the formal setting of the hearing process.

The project was organized in three phases: (1) data review; (2) model-specific data input development; and (3) exploratory analysis, focusing on the CEC model framework.

As part of our initial review of the data, we calculated annual electricity consumption (also called a unit energy consumption or UEC in forecasting) for each end use (and by region for space cooling). Where available, statistical weights provided by PG\&E's load research group 
were used in an effort to make the sample of end-use metered customers more representative of the population of PG\&E customers. We found that the use of statistical weights tended to yield lower space cooling UECs. More importantly, we found that the UECs developed from metered data differed, often substantially, from the UECs assumed by both PCi\&E and CEC in the forecasts. While there are many appropriate reasons for the differences, examining these differences was outside the scope of the current project. It is clear, however, that the metered Jata provide a rich empirical basis for systematically assessing the sources of differences in the future.

For the CEC model, we analyzed five years of residential air-conditioning data to develop timetemperature matrices. Time-temperature matrices express hourly air-conditioning energy use as a function of both time of day and a measure of climatic severity called the temperaturehumidity index (THI). A single matrix was developed from all five years of data. To ensure continuity between adjacent values and also to allow CEC to use the matrix to forecast conditions not observed in the original data, we developed an extrapolation and smoothing technique and applied it to the data.

We conducted limited evaluations of the accuracy of the time-temperature matrix in "predicting" the actual load observations that were used in its development. We found that the timetemperature matrix developed from all five years of central $A / C$ data performed accurately in "predicting" average summer loads. The hour of the peak demand was predicted in a relatively un-biased manner, except for one region. But we found that peak daily loads were overpredicted.

These findings underlie what we believe to be important, but not well appreciated, trade-offs in accuracy between the different forecasting applications of the CEC time-temperature matrix (and, we believe, the PG\&E model). That is, while forecasting system peak demands remains critically important for the planning process, other forecast quantities (such as hourly loads on non-system peak days and minimum load conditions) have increased in importance. Even for the system peak day, there are trade-offs in accuracy between forecasting the absolute $\mathrm{kW}$ value of the peak for the space cooling end use, the timing of that peak, and the load that is coincident with the time of the system peak. At the present time, the relative importance of these trade-offs has not been assessed.

For the PG\&E model, we analyzed five years of residential air-conditioning data to develop daily weather response functions and binned hourly load shapes according to definitions established by PG\&E in previous research. The weather response functions allocate forecasts of annual energy use (developed by a separate PG\&E forecasting model) to the days of the year based on a combination of average temperature on the current and previous two days. The binned hourly load shapes spread daily energy use over the hours of the day, also based on average daily temperature. Both were developed separately for three of the four regions used by PG\&E to forecast loads for its service territory. There were insufficient data to support analysis for PG\&E's fourth region (in part, because the need for and saturation of airconditioning is extremely low in this region). We also identified options for future 
enhancements to the specification of the functional form of the weather response function and its development from the metered data.

We also developed seasonal and daytype allocation factors, and load shapes for four non-space conditioning end uses (refrigeration, water heating, clothes drying, and cooking) for the CEC model. (PG\&E does not forecast individual, non-space conditioning end uses in its load shape forecasting model.) These results were based on three years of metered data collected by PG\&E. Our analysis of these data suggests that differences in energy use by daytype (e.g., weekend vs. weekday) are much more important to capture than differences by month (e.g., January vs. February).

We also initiated exploratory analysis to begin to address issues regarding the cost-effectiveness of end-use metering. Working within the framework of the CEC model, we considered (but by no means reached complete resolution of) two issues: how much geographic coverage was appropriate and how many years of data should be collected.

We found that the energy used by central air-conditioners in the different regions used by CEC for forecasting purposes exhibited variations that could not be accurately generalized using the CEC model framework. Backcasts of observed Fresno loads, using the time-temperature inatrix developed from only Fresno data, were slightly more accurate than loads backcast from the matrix developed from data from all regions. We also found that the number of year of data used to develop the time temperature matrix did influence the accuracy of the matrix in predicting loads observed in other years.

Our results suggest that, at this time, relying on multiple years of data, but possibly analyzing them separately by geographic region may be appropriate. However, the larger question raised by our preliminary findings is; on the one hand, whether more accurate representations of the data can be developed, and, on the other, whether these findings can inform efforts to supplement or to more tightly focus future metering activities.

End-use metering is expensive. Its cost must be justified by the value that the information collected brings to the planning process and other uses of the data. We believe that this value is enhanced by cooperative research sponsored by the ultimate users of the data. We also believe that we have only begun to tap the wealth of information contained in them.

Our work to date suggests several areas for future research:

(1) Prioritization of the outputs forecast by load shape models (such as system peak demand and timing, end-use peak demand, average daily load shapes, and minimum load conditions) so that these priorities can be explicitly reflecter in future analyses.

(2) Examination of alternative methods for representing load shape data in forecasting, starting with space cooling. These methods would examine 
alternative measures of climate severity and alternative schemes for "normalizing" weather response.

(3) Examination of supplementary data (such as mail surveys and billing records) to evaluate alternative statistical weights for aggregating data to represent the PG\&E population of customers within the disaggregate end-use framework used by CEC and PG\&E for forecasting. 


\section{Chapter 1 Introduction}

It is generally acknowledged that improvements to electricity load shape and peak demand forecasts are limited primarily by the absence of reliable end-use data. In the past, utility and state forecasters have relied on a combination of simulated, borrowed end-use, and class load research data. In part this situation results from the structure of existing load shape and peak demand forecasting methods, which take annual electricity use that has been calculated previously by a separate forecasting model and allocate this calculated use to the hours of the year. However, recent end-use metering by utilities promises to dramatically improve not only the data used by existing load shape forecasting models but also to provide the basis for the next generation of modeis to forecast end-use annual energy and hourly demand.

In this study, we report results from our analysis of end-use metered data collected by the Pacific Gas and Electric Company (PG\&E) from more than 700 residential customers between 1985 and 1989. The analysis centered on developing new inputs to the load shape and peak demand forecasting models currently used by PG\&E and the Califormia Energy Commission (CEC) in their biennial forecasts of electricity demand.

The goal of the analysis is to provide a common set of inputs that both models can use to represent the hourly pattern of electricity use. Although unique features of the PG\&E and CEC models make it impossible to develop a single set of inputs usable by both models, we applied consistent analysis procedures to the data up to the point at which model-specific data formatting was required to ensure that the resulting inputs are compatible with one another.

This report is organized in seven sections following this introduction. We begin by describing the PG\&E and CEC load shape and peak demand forecasting models (Chapter 2) and the PG\&E end-use metered data (Chapter 3). We provide an overview of data preparation and analysis procedures and discuss our evaluation criteria for the CEC model in Chapter 4. Because of the richness of the data set, the structure of the models, and especially because of the importance of residential cooling to forecasts of energy use, PG\&E and CEC are keenly interested in this end use. Our analyses leading to revised cooling load shape data for the models are presented separately for CEC and PG\&E in Chapters 5 and 6, respectively. The CEC model requires additional load shape data on individual non-space conditioning end uses; this analysis is presented in Chapter 7. Six appendices provide additional documentation for the analyses presented in the body of the report, including details of the data preparation procedures and tabular summaries of the load shape information presented in Chapters $3,5,6$, and 7 . We also present results from our exploratory analysis on subsets of the data based on the CEC model's representation of central air conditioning load shape. 


\section{Chapter 2 \\ PG\&E and CEC Load Shape and Peak Demand Forecasting Modiels}

Existing hourly electricity load shape and peak demand models are essentially post-processors for end-use forecasting models, which separately develop annual forecasts of energy use. Equipment purchase and energy use decisions, stock turnover, and other economic and demographic factors are treated as influences primarily on annual energy use. In this framework, the goal of the load shape and peak demand model is to allocate the estimated annual total load to the hours of the year.

PG\&E uses a load shape forecasting model called HELM, developed by ICF, Inc. for the Electric Power Research Institute (ICF 1991). The model is very flexible; it allows the user to define the number of end uses for which it will generate up to an 8,760-hour forecast of energy use. For a given end use and year, the user defines hourly load shapes for a limited number of day-types and assigns day-types to all the days in a calendar year. Then the model distributes annual energy use (a figure also supplied by the user) to the hours of the year, using allocation factors previously defined. For weather-sensitive end uses, such as cooling, the allocation procedure can also be based on measures of climatic variables, such as a three-day weighted average of mean daily temperature. In this case, the model also requires a daily weather file for the year. Daily energy use is allocated to the hours of the day using normalized load shapes. The choice of normalized load shape can be specified as a function of weather variables.

PG\&E defines seven separate end uses for the residential sector: three separate space cooling and three non space cooling end uses corresponding to three geographic zones within the company's service territory, and a single combined end use for a fourth geographic zone (PG\&E 1991).

CEC uses a peak demand model that was developed in-house in the late 1970's (Jaske and Paige 1979). The CEC model is more structured than HELM because it was designed in conjunction with end-use annual energy forecasting models that were also developed by CEC. For the residential sector, the CEC model requires annual energy forecasts for 14 non-space conditioning and five space conditioning end uses for each geographic region considered. In the past, the CEC model has been used mainly to produce system peak day load forecasts although the model is, in principle, capable of producing forecasts for non-peak days.

The CEC model allocates forecasts of annual energy use to the hours of the year in two steps. For non-space conditioning end uses. the allocation process closely resembles that of HELM. First, annual energy use is distributed by days according to factors that express daily average energy use (for a particular combination of season and day type) as a function of annual daily average energy use. Second, daily energy use is allocated to the hours of the day using average daily load shapes. For non-space-conditioning end uses, four seasonal allocation factors and a 
single day-type for each season are used. For space conditioning end uses, as with HELM, annual space conditioning energy use is first allocated to daily energy use using weather data: CEC uses a three-day weighted average of degree-days, rather than mean daily temperatures, as used by PG\&E. For cooling, degree-days are based on a combined dry- and wet-bulb temperature variable called a temperature-humidity index or THI. For heating, dry-bulb degreedays are used. Unlike HELM, the CEC model does not spread daily energy use to the hours of the day using a fixed load shape. Instead hourly energy use is expressed as a function of time of day and THI (for cooling) or dry-bulb temperature (for heating), in what CEC refers to as a time-temperature matrix.

To forecast system peak demands for the PG\&E planning area, the CEC model produces separate forecasts for five geographic regions in the PG\&E service territory (CEC 1991). Because the same non-space-conditioning seasonal allocation factors and daily load shapes are used for all five regions, the forecasts differ qualitatively only for space-conditioning energy use. More precisely, while non-space-conditioning energy use forecasts differ substantially because of region-specific differences in end-use saturations and energy use, the allocation factors and load shapes used are identical. 


\section{Chapter 3 The PG\&E Appliance Metering Project}

PG\&E's Appliance Metering Project (AMP) was the first large-scale end-use metering project in California (PG\&E 1987). Since 1983, more than 700 single-family, owner-cccupied residences have been continuously metered. In designing the project, PG\&E was particularly interested in improving its understanding of the contribution of space cooling energy use to system loads. As a result, the geographic distribution of metered households is concentrated in the hot central valley of California where the demand for cooling is greatest.

For each household, two appliances were metered in addition to total household load. In the entire sample, a total of sixten different appliance types were metered. Table 3-1 lists these appliances and the number metered. In this study, we analyze data for seven end uses: central air conditioning, room air conditioner, clothes dryer, a miscellaneous kitchen circuit, refrigerator, and water heater and another end use, made up of a combination of four metered appliances: range only, range with oven, oven only, and range with oven and microwave which we call "cooking". The miscellaneous kitchen circuit is a general kitchen end use that excludes cooking but may include refrigeration in addition to lights and miscellaneous appliances. We do not report results for heat pump compressor, nor are heat pump compressor data included in any of our cooling end uses. Table 3-2 shows the geographic distribution of cooling appliances by CEC Region and by PG\&E Zone. Several regions do not have significant numbers of metered data (e.g., in the case of central air conditioning, CEC Region 1 and 5, and PG\&E Zone T). As a result, we do not report separate analyses for these regions and zones.

PG\&E provided LBL with three years of data for space conditioning end uses (1987-1989) and one year of data for non-space-conditioning end uses (1989). In an earlier project (see Ruderman et al. 1989), PG\&E provided LBL with space-conditioning and non-space-conditioning AMP data for 1985 and 1986. Thus, in total, we examined five years of space-conditioning and three years of non-space-conditioning data from the AMP. PG\&E replaced all information that might identify individual customers with a seven digit code that identified the households across data sets.

PG\&E has developed weights to make the sample more representative of the entire residential class, and to account for the stratified nature of the AMP sample (Brodsky \& Associates 1991). These weights were not available from PG\&E in time for most of our analyses. Therefore, with the exception of the weighted mean UECs presented in this chapter, the results presented in this report were developed through unweighted analyses of the data. Our unweighted analyses are theoretically reflective only of loads for single-family owner-occupied residences; furthermore, for these loads, we cannot determine what biases may exist as a result of the process used to select participants for the project. 
Descriptive statistics on the data analyzed in this project are summarized in Tables 3-3 through 3-7. For each end use (sometimes a combination of several appliances, see Table 3-1), we report the mean and standard deviation of unweighted annual energy use (or UEC for "unit energy consumption"), and the average number of appliances crmtributing each month to the UEC for the year. We also report weighted mean UECs for each case in which analysis weights were provided. The statistics are reported for each year separately and for all years together. For the space-conditioning end uses, we report these data by CEC Region (Tables 3-3 and 3-4) and by PG\&E Zone (Tables 3-5 and 3-6), for each year separately and for all years together. For central air conditioners, weights were developed (by PG\&E) only for summer months (May through October). In order to compute annual weighted UECs, we applied the summer weights to the energy use in winter months as well. Other computational details are discussed in Appendix A.

Statistics for CEC Regions 1 and 5 and statistics for room air conditioners in PG\&E Zone R and CEC Region 2 are not tabulated separately because of the small number of appliances in each region; however, these data are included in the summaries for all regions. Below we compare UECs computed without analysis weights to those computed using the PG\&E-supplied analysis weights and also compare the UECs we computed to those used by PG\&E and CEC in thi ir forecasts. We also discuss the variability from year to year of the annual mean UECs we computed.

Annual mean central air conditioner weighted UECs are lower than the corresponding unweighted UECs, in all cases but one (1987 PG\&E Zone X, for which weighted UEC is 1.1 percent higher than the unweighted UEC). The effect is greatest for UECs for the hottest areas (Zone R and CEC Region 3, and to a lesser extent Zone S and CEC Region 2), with the level of effect in those regions fairly consistent over the three years considered.

For CEC Region 2, central air conditioner annual mean weighted UECs are 11.7, 12.4, and 10.5 percent lower than unweighted UECs for 1987, 1988, and 1989 respectively (see Table 3-3). Region 3 central air conditioner annual mean weighted UECs are 16.4, 14.4, and 10.3 percent lower, and Region 4 weighted UECs $1.5,9.0$, and 5.2 percent lower, than the corresponding unweighted UECs for 1987, 1988, and 1989 respectively. Patterns for PG\&E Zones are similar, with annual mean weighted UECs ranging from 17.4 percent lower (1987 Zone R) to 1.1 percent higher (1987 Zone X) than corresponding unweighted UECs.

Analysis weights for room air conditioner were available only for 1989 . For this year, weighted mean UECs for room air conditioner are again lower (from 3.0 to 12.1 percent) than the corresponding unweighted mean UECs (see Tables 3-4 and 3-6).

We also compared weighted to unweighted UECs for three non-conditioning end uses, clothes dryer, refrigerator, and water heater, for the year (1989) for which analysis weights for these end-uses were available. Weighted 1989 mean UECs are 11.5, 18.7, and 1.3 percent lower than unweighted 1989 mean UECs for clothes dryer, refrigerator, and water heater, respectively. (Analysis weights were not provided for range with oven and microwave, one of the components 
of the cooking end use, so that weighted UECs for cooking could not be computed, nor were analysis weights provided for the kitchen circuit end use.)

Table 3-8 shows 1989 UECs used by PG\&E and CEC in their forecasts along with the unweighted and weighted UECs we computed from the metered data. To facilitate comparisons, we compare UECs for the total residential sector over the entire PG\&E service area (although UECs are available by climate zone and, from CEC, also by housing type). The PG\&E UECs are as reported in the Revised ER 92 Forecast of the Demand for Electricity (PG\&E 1991). We computed UECs for the total residential sector, from UECs reported by CEC by housing type (single family, multi-family, and mobile home) and climate zone (CEC 1992). CEC's and PG\&E's central air conditioner end use includes heat pump compressor whereas LBL's central air conditioner end use does not. CEC also reports water heating separately for clothes washer, dishwasher, and other water heating; we report the sum of these three UECs as well as the UEC for water heating excluding clothes washer and dishwasher. LBL UECs are from the all regions summaries in Tables 3-3 through 3-7.

Annual regional mean UECs for central air conditioner vary considerably from year to year. The ratio of the highest to the lowest annual UEC observed in the five years of data are 1.42, 1.32, and 1.53 for CEC Regions 2, 3, and 4, respectively (see Table 3-3). Annual UEC for room air conditioners also varies considerably from year to year, but since relatively few room air conditioners were metered, reliable comparisons are difficult. We also computed the mean UEC on a monthly basis for central and room air conditioners. These monthly statistirs are reported, by CEC Region and by PG\&E Zone, in Appendix B.

Annual mean UEC for clothes dryer, water heater, kitchen circuit, and cooking consistently decrease during the three study years (decreasing between 1985 and 1986 and again between 1986 and 1989). The changes are small, though, with UECs that are 6.0, 8.2, 5.2, and 3.9 percent lower in 1989 than in 1985 for clothes dryer, appliances, kitchen circuit, and water heater, respectively, and of questionable statistical significance.

The purpose of the comparisons of un-weighted and weighted UECs, and of the UECs used by PG\&E and CEC in their forecasts is not to suggest that one of these UECs is the "best" UEC to use in forecasting. Rather, it is to point out that there are significant differences that need to be better understood by all parties. In particular, the conventions and definitions used to develop the UECs used in the forecasts and the sample weights for the AMP data, as well as biases that may exist within the AMP sample, should be subjected to comprehensive review. This review is outside the scope of the current project. 
Table 3-1

Number of Appliances Metered

andyzed in this study

Central Air Conditioner . . . . . . . . . . . . . . . . . . . . . . 415

Wall Air Conditioner . . . . . . . . . . . . . . . . . . . . . . 65

Clothes Dryer . . . . . . . . . . . . . . . . . . . . . . . . . 396

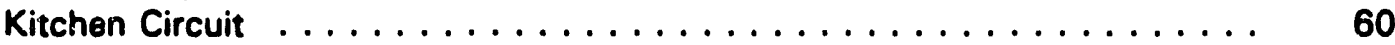

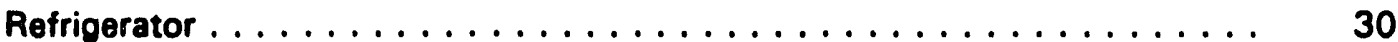

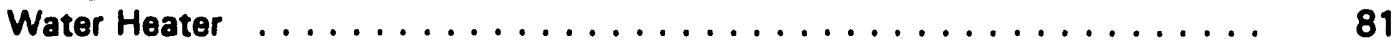

combined into singlo end use "Cooking"

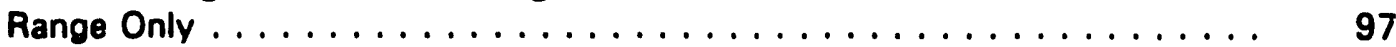

Range with Oven ............................... 208

Oven Only ................................... 32

Range with Oven and Microwave . . . . . . . . . . . . . . . . . . . . . . . . . . . . . . . . . . . . . .

Cooking (total) ............................. 351

not analyzed in this study

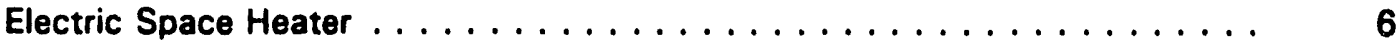

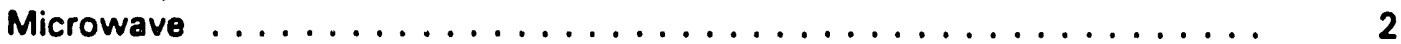

Clothes Washer ............................... 1

Heat Pump Compressor . . . . . . . . . . . . . . . . . . . . 67

Heat Pump Strip ............................ 16

Freezer ................................. 3

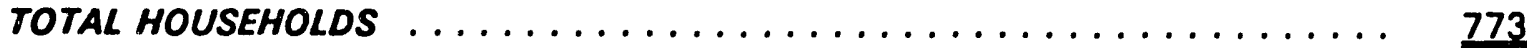


Table 3-2

Number of Central and Room Air Conditioners Metered by CEC Region and PG\&E Zone

End Uses Analyzed in this Study

Central Air Conditioner lall rogions) ................... 415

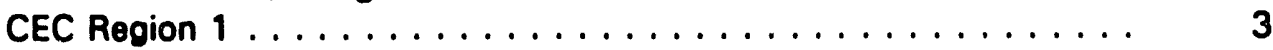

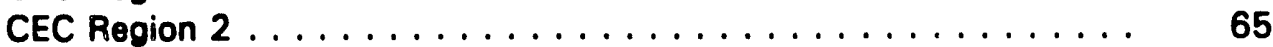

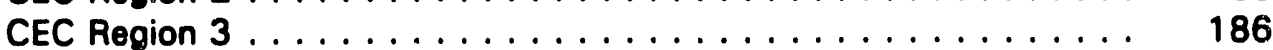

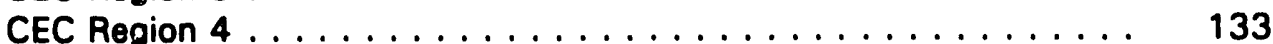

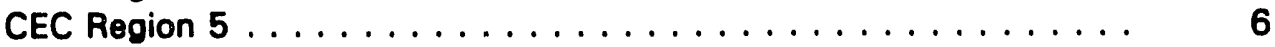

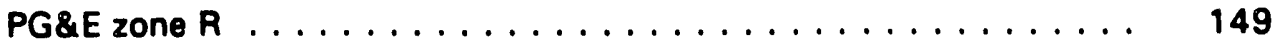

PG\&E zone $S \ldots \ldots \ldots \ldots \ldots \ldots \ldots \ldots \ldots \ldots \ldots \ldots \ldots \ldots$

PG\&E zone $T \cdot \ldots \ldots \ldots \ldots \ldots \ldots \ldots \ldots \ldots \ldots \ldots \ldots \ldots$

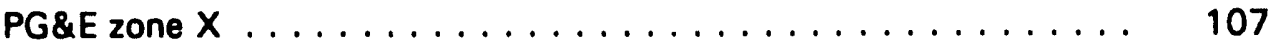

Room Air Conditioner lall rogions) $\ldots \ldots \ldots \ldots \ldots \ldots \ldots \ldots \ldots \ldots$

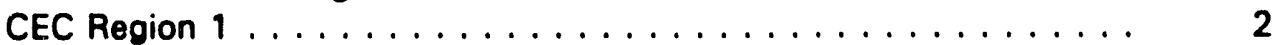

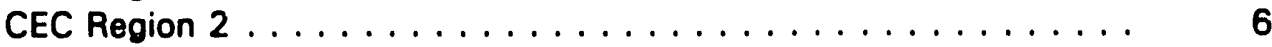

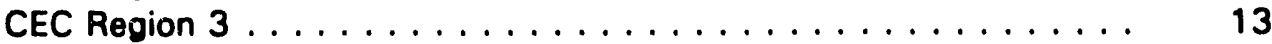

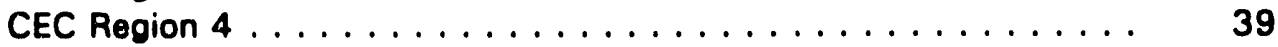

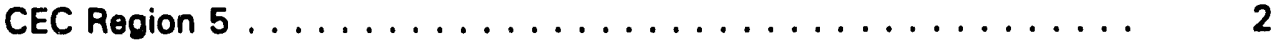

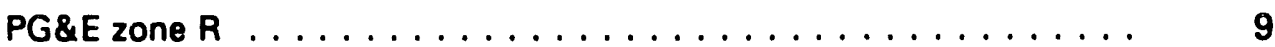

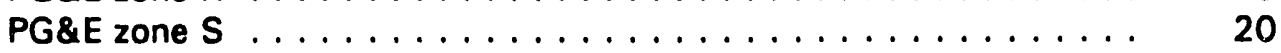

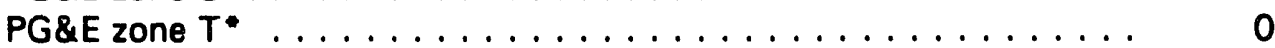

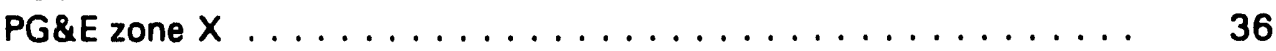

- PG\&E zone $T$ is not analyzed in this study

For a description of CEC regions 1-5 and PG\&E zones $R, S, T$ and $X$, please refer to Figures $A-1$, $A-2, A-3, A-4$ and $A-5$. 
Table 3-3

Annual UEC for Central Air Conditioning, CEC Regions

\begin{tabular}{|c|c|c|c|c|c|c|}
\hline APPLIANCE & 1985 & 1986 & 1987 & 1988 & 1989 & all yoars \\
\hline $\begin{array}{l}\text { all Regions } \\
\text { mean } \\
w \text { t.mean } \\
n\end{array}$ & $\begin{array}{r}1,254 \\
n / a \\
288\end{array}$ & $\begin{array}{r}1,112 \\
n / a \\
267\end{array}$ & $\begin{array}{r}1.424 \\
1.283 \\
337\end{array}$ & $\begin{array}{r}1,607 \\
1,429 \\
318\end{array}$ & $\begin{array}{r}1,094 \\
996 \\
332\end{array}$ & $\begin{array}{r}1,294 \\
n / a \\
308\end{array}$ \\
\hline $\begin{array}{l}\text { Region } 2 \\
\text { mean } \\
\text { wt.mean } \\
\text { std.dev. } \\
n\end{array}$ & $\begin{array}{r}1,149 \\
n / a \\
443 \\
48\end{array}$ & $\begin{array}{r}1,098 \\
n / a \\
373 \\
42\end{array}$ & $\begin{array}{r}1,250 \\
1,104 \\
486 \\
56\end{array}$ & $\begin{array}{r}1,400 \\
1,227 \\
449 \\
49\end{array}$ & $\begin{array}{r}989 \\
885 \\
362 \\
50\end{array}$ & $\begin{array}{r}1,174 \\
n / a \\
445 \\
49\end{array}$ \\
\hline $\begin{array}{l}\text { Region } 3 \\
\text { mean } \\
\text { wt.mean } \\
\text { std.dev. } \\
n\end{array}$ & $\begin{array}{r}1,606 \\
n / a \\
552 \\
118\end{array}$ & $\begin{array}{r}1,499 \\
n / a \\
526 \\
107\end{array}$ & $\begin{array}{r}1,816 \\
1,531 \\
676 \\
147\end{array}$ & $\begin{array}{r}1.982 \\
1.697 \\
646 \\
138\end{array}$ & $\begin{array}{r}1.378 \\
1.236 \\
527 \\
141\end{array}$ & $\begin{array}{r}1,651 \\
n / a \\
626 \\
130\end{array}$ \\
\hline $\begin{array}{l}\text { Region } 4 \\
\text { mean } \\
\text { wt.mean } \\
\text { std.dev. } \\
n\end{array}$ & $\begin{array}{r}946 \\
n / a \\
480 \\
103\end{array}$ & $\begin{array}{r}724 \\
n / a \\
425 \\
98\end{array}$ & $\begin{array}{l}936 \\
922 \\
779 \\
108\end{array}$ & $\begin{array}{r}1,051 \\
956 \\
586 \\
105\end{array}$ & $\begin{array}{l}688 \\
652 \\
435 \\
120\end{array}$ & $\begin{array}{r}849 \\
n / a \\
563 \\
107\end{array}$ \\
\hline
\end{tabular}


Table 3-4

Annual UEC for Room Air Conditioning. CEC Regions

\begin{tabular}{lrrrrrr}
\hline APPLIANCE & 1985 & 1986 & 1987 & 1988 & 1989 & all years \\
\hline all Regions & & & & & & \\
mean & 344 & 363 & 476 & 668 & 477 & 475 \\
wt.mean & $n / a$ & $n / a$ & $n / a$ & $n / a$ & 514 & $n / a$ \\
$n$ & 41 & 40 & 50 & 51 & 48 & 46 \\
Region 3 & & & & & & \\
mean & 371 & 595 & 578 & 754 & 343 & 521 \\
wt.mean & $n / a$ & $n / a$ & $n / a$ & $n / a$ & 325 & $n / a$ \\
std.dev. & 188 & 254 & 262 & 307 & 208 & 261 \\
$n$ & 10 & 9 & 8 & 10 & 10 & 9 \\
Region 4 & & & & & & \\
mean & 296 & 226 & 433 & 502 & 393 & 373 \\
wt.mean & $n / a$ & $n / a$ & $n / a$ & $n / a$ & 381 & $n / a$ \\
std.dev. & 134 & 120 & 474 & 181 & 151 & 275 \\
$n$ & 103 & 98 & 108 & 105 & 120 & 107 \\
& & & & & & \\
\hline
\end{tabular}


Table 3-5

Annual UEC for Central Air Conditioning, PG\&E Zones

\begin{tabular}{lrrrrrr}
\hline APPLIANCE & 1985 & 1986 & 1987 & 1988 & 1989 & all years \\
\hline all regions & & & & & & \\
mean & 1,254 & 1,112 & 1,424 & 1,607 & 1,094 & 1,294 \\
wt.mean & $n / a$ & $n / a$ & 1,283 & 1,429 & 996 & $n / a$ \\
$n$ & 288 & 267 & 337 & 318 & 332 & 308 \\
Zone R & & & & & & \\
mean & 1,802 & 1,700 & 2,002 & 2,294 & 1,684 & 1,905 \\
wt.mean & $n / a$ & $n / a$ & 1,653 & 1,911 & 1,519 & $n / a$ \\
st.dev. & 565 & 543 & 718 & 701 & 601 & 678 \\
$n$ & 86 & 82 & 117 & 113 & 111 & 102 \\
Zone S & & & & & & \\
mean & 1,277 & 1,188 & 1,367 & 1,538 & 1,018 & 1,265 \\
wt.mean & $n / a$ & $n / a$ & 1,270 & 1,380 & 895 & $n / a$ \\
st.dev. & 553 & 495 & 576 & 580 & 479 & 438 \\
$n$ & 116 & 102 & 132 & 118 & 123 & 118 \\
Zone X & & & & & & \\
mean & 682 & 497 & 709 & 790 & 521 & 629 \\
wt.mean & $n / a$ & $n / a$ & 717 & 753 & 500 & $n / a$ \\
st.dev. & 249 & 239 & 737 & 443 & 254 & - \\
$n$ & 80 & 80 & 86 & 86 & 97 & 86 \\
& & & & & & \\
\hline
\end{tabular}


Table 3-6

Annual UEC for Room Air Conditioning PG\&E Zones

\begin{tabular}{lrrrrrr}
\hline APPLIANCE & 1985 & 1986 & 1987 & 1988 & 1989 & all yosers \\
\hline all regions & & & & & & \\
mean & 344 & 363 & 476 & 668 & 477 & 475 \\
w. mean & $n / a$ & $n / a$ & $n / a$ & $n / a$ & 514 & $n / a$ \\
$n$ & 41 & 40 & 50 & 51 & 48 & 46 \\
Zone S & & & & & & \\
mean & 465 & 617 & 633 & 980 & 629 & 680 \\
wt. mean & $n / a$ & $n / a$ & $n / a$ & $n / a$ & 651 & $n / a$ \\
std. dev. & 201 & 253 & 250 & 325 & 249 & - \\
$n$ & 12 & 11 & 14 & 18 & 17 & 14 \\
Zone X & & & & & & \\
mean & 286 & 217 & 425 & 495 & 395 & 369 \\
wt. mean & $n / a$ & $n / a$ & $n / a$ & $n / a$ & 362 & $n / a$ \\
std. dev. & 130 & 120 & 487 & 186 & 149 & - \\
$n$ & 23 & 23 & 31 & 27 & 26 & 26 \\
& & & & & & \\
\hline
\end{tabular}


Table 3-7

Annual UEC for Non-Conditioning Appliances

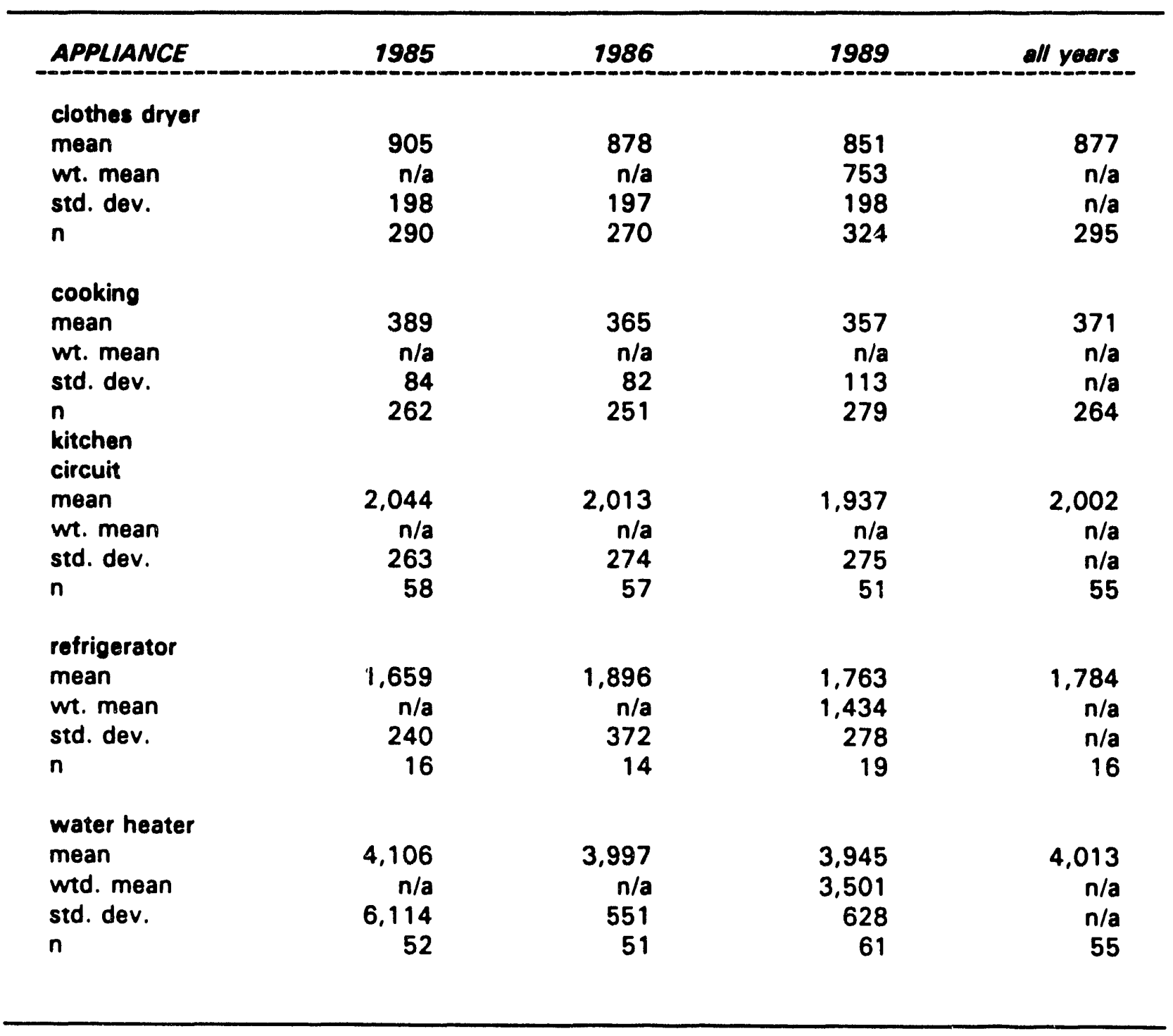


Table 3-8

Comparison of 1989 UECs assumed in PG\&E and CEC forecasts and UECs

Calculated by LBL

(UECs are in kWh/unit/year)

UEC Total Residential

Sector

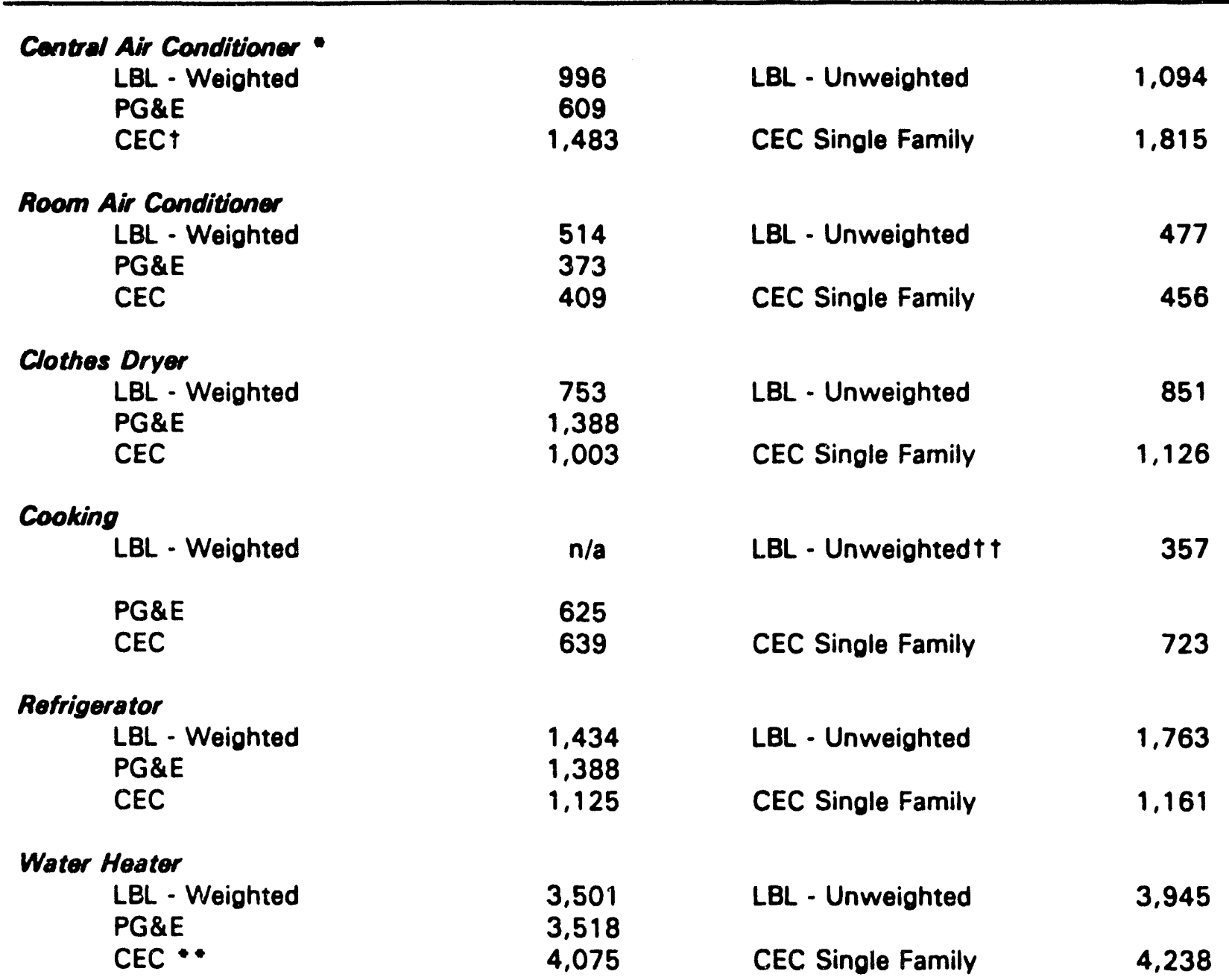

- includes heat pump compressor for PGsE and CEC

- sum of CEC's water heater, hot weter dishwasher, and hot water clothes washer UEC8 12,157, 913 and 1,005 kWh respectively for total residential sector).

$\uparrow \quad$ total residential sector UEC reportisd for CEC are weighted averages of single-family, multi-family and multiplehome UECs.

$\dagger+\quad$ LBL's cooking UEC is an average over combined appliance type, not a aum of UECs over individual appliance types. 


\section{Chapter 4 \\ Method of Analysis}

In this section, we summarize our preparation of the data for analysis, referring many of the technical details to Appendix A. We also provide an overview of the procedures common to all of our analyses, which are reported in detail in Chapters 5, 6, and 7. Finally, we define the procedures developed to assess our analysis, including backcasting and various measures of goodness of fit. At this time, these procedures apply only to our evaluation of the load shape representation used by the CEC model and presented in Chapter 5 and Appendix F.

The data provided by PG\&E were subjected to extensive review by the PG\&E load research group. In general, we relied on their efforts and used the data without extensive additional review, beyond treatment of missing data. To improve our familiarity with the data set and develop our missing data treatments, we subjected the 1989 space conditioning data to an additional internal review. We did range checks on hourly loads, compared air conditioner load to total household load, assessed data completeness, and visually examined a "threedimensional" graph for each metered air conditioner showing the 8,760 hours of air conditioner load for the year, by hour of day. Appendix A contains a detailed technical summary of these activities. We reviewed the results of these procedures with PG\&E's load research group. As a result, we recoded as missing 1989 cooling data for two residences, and removed duplicate data for a third residence.

A second part of our data validation was a review of CEC Region assignments. For each residence reporting metered air conditioner data, we evaluated the region assignment initially given (these were indirect assignments, as detailed in Appendix A) and proposed reassignments when indicated. We discussed these proposed reassignments with CEC staff, and, with their approval, recoded assignments to CEC Regions for residences in 41 zip code areas.

The basic procedure for all our analyses of the AMP data is aggregation. For non-spaceconditioning end uses, we aggregated the cooking appliances as indicated in Table 3-1. For all end uses, aggregations were made both across years and, to differing degrees, within years. For space-conditioning, separate aggregations were made for each geographic region. As we will describe in Chapters 5 and 6, PG\&E and CEC rely on different definitions for their geographic forecasting areas.

Following aggregation across appliances, years, and geographic regions, we then proceeded with analyses that were specific to the requirements of each model. These analyses are described separately in Chapters 5, 6, and 7.

As noted in Chapter 2, historically, the CEC model had been used to produce load forecasts for only system peak days. However, we have developed new time-temperature matrices is based on cooling loads for all days. We evaluate the performance of the matrix for predicting load 
shapes on summer days as well as for the hottest days. Our primary strategy for evaluating the CEC matrices involved using them to backcast the observed conditions upon which the analyses were originally based. Specifically, we used the matrices along with historic weather to predict daily load shapes. We then compare our prediction to the mean load shape of the AMP sample on the day from which the historic weather was taken. Thus, for each CEC Region we derive a pai' of load shapes for each day during the period from 1985 to 1989 . Each pair consists of a backcast load shape derived from applying the hourly THI values for the CEC Region's NOAA weather station to the time-temperature matrix, and a sample mean load shape derived from all metered central air conditioner data for that region and day. For the purposes of the comparisons described below, we expressed both the backcast and sample load shapes on an energy-normalized scale (so that a day's 24 hourly loads add up to 1). Because of the small number of air conditioners metered in CEC Regions 1 and 5, we compared load shape pairs for only Regions 2, 3, and 4.

In comparing load shapes, we relied on both visual inspection and more formal, quantitative measures of goodness of fit. For each day's pair of load shapes we computed measures describing four aspects of the daily load shape:

- timing of peak hour

- magnitude of peak

- magnitude of load at time of an exogenously specified system peak hour (4 p.m.)

- the square root of the daily sum of the square of deviations from the recorded value

We discuss these measures below. Figure 4-1 illustrates the measures for a sample comparison of load shapes. ${ }^{1}$

To compare Tining of Peak Hour, we computed the difference between the hour of day of the peak load for the sample mean load shape and the hour of day of the peak hour for the backcast load shape. For example, if the peak hour of the backcast load shape was 5 p.m., and the peak hour of the sample mean load shape was 4 p.m., we defined the backcast load shape peak as being one hour late. This is shown as the difference a in Figure 4-1. We report the percentage of days for which the backcast load shape peak is one hour late, one hourly early, etc.

To compare Magnitude of Peak, we computed the difference between the peak hourly load of the sample load shape and the peak hourly load of the backcast load shape. The hours compared are not necessarily the same hour of day, as indicated by the previous measure. We computed these peak load level differences on an energy normalized scale. This difference is illustrated as difference $b$ in Figure 4-1.

'Loads are expressed as $\%$ daily load in the figure, but as proportion of daily load $(\% / 100)$ for computations reported in Chapter 5 and Appendix F tables. 
In recent years, 4 p.m. has often been the peak system demand hour for PG\&E, so we also compared backcast and sample Magnitude of 4 p.m. Load by computing the difference between sample 4 p.m. load and backcast 4 p.m. load. This is the difference $c$ in Figure 4-1.

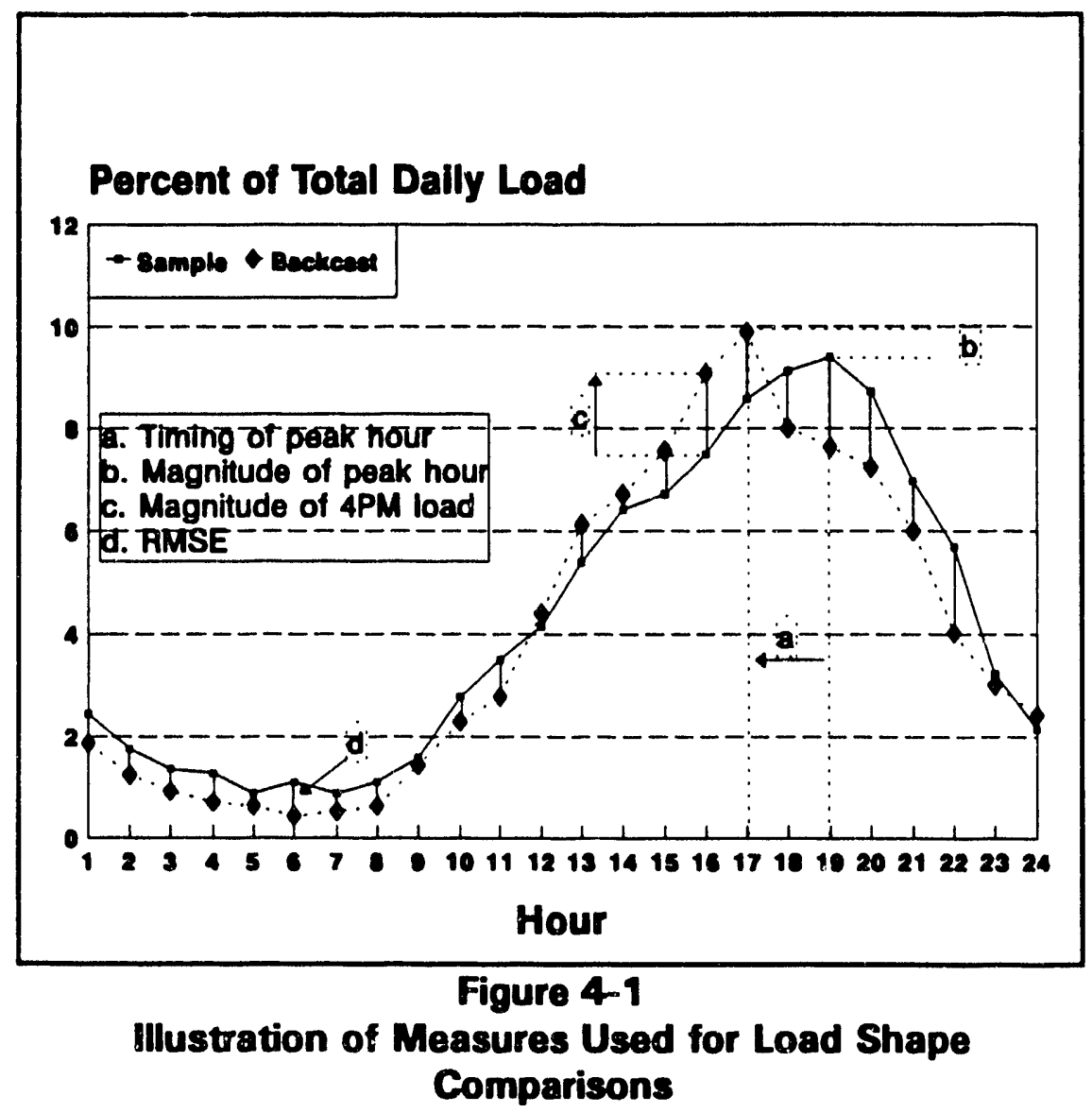

Finally, we computed a general measure of load shape similarity called root-mean-square-error or RMSE, which is the square root of the mean squared difference between backcast and sample load over the 24 hours of the day. Squaring the difference exaggerates large errors more than an absolute-difference measure would. RMSE is the sum of the sequence of the differences d in the figure. Formally, $R M S E=\left[\sum_{h=1}^{24}(\text { sample }[h]-\text { backcast }[h])^{2}\right]^{1 / 2}$ 


\section{Chapter 5 \\ Cooling Electricity Use Analysis for CEC Peak Demand Model}

Using all five years of AMP data, we developed central air conditioner time-temperature matrices, following the format used by the CEC Peak Demand Model. In this section, we summarize the construction of these matrices and discuss the match between backcasts based on the new all-region time-temperature matrix and the sample load shapes. As noted in Chapter 2, our results are based on unweighted analyses of the data.

The time-temperature matrix defines a correspondence between a cell, defined as a combination of: hour of day (1 through 24), value of a temperature-humidity index (or THI), and an average load in $\mathrm{kWh}$ for a particular end use. The matrix is used by the CEC space-conditioning demand model to generate a daily load shape, which is subsequently scaled by other factors, as described in Chapter 2 of this report. We developed a single time-temperature matrix based on data from all regions for all five years. ${ }^{2}$ We developed the matrix in two steps: first we prepared a "raw" time-temperature matrix, and second, we derived a "smoothed" timetemperature matrix based on the raw matrix.

To prepare the raw time-temperature matrix, we calculated a THI for each reported hour of the 1985-1989 data record at each of the following five NOAA weather stations: Blue Canyon, Fresno, Sacramento, San Francisco, and San Jose. Because NOAA data to the San Jose station were not available for 1985, we substituted data from nearby Sunnyvale for San Jose for 1985. These THI values, rounded to the nearest integer, ranged from 45 to 89 . Next we assigned each hour of central air conditioner load for each residence to a hour-THI cell, based on hour of day and value of THI for the NOAA station corresponding to the residence's CEC Region assignment. We then computed a cell mean for each observed hour-THI combination. This mean load is estimated across all hours, using the residences and dates assigned to the cell.

Figure 5-1 shows the resulting raw time-temperature matrix. Tabular summaries of these data are presented in Appendix $C$. The raw data do not fill every cell in the matrix. Moreover, the plot looks uneven, varying from the smooth surface we might expect because of the small number of data used to compute the values for some of the cells on the graph, particularly at time-temperature combinations expected to have high loads. Intuition suggests that the timetemperature matrices ought to behave smoothly across time-temperature load surface. Assuming that this intuition is correct, one could theoretically, obtain better estimates of mean load for a given cell of the time-temperature matrix by using information from neighboring cells. This approach is particularly appealing if a cell contains few observations. For example, only 39 hours of metered results of data contributed to the hour-19-THI-88 cell, while 1,945 hours of

\footnotetext{
2 Appendix F reports findings from exploratory analyses to develop matrices from subsets of the data.
} 
metered data contributed to the hour 19-THI-87-cell, and 165 hours contributed to the hour-18THI-88 cell, etc. (see Table C-3). Therefore, information from the cells neighboring the hour19-THI-88 cell might be used to obtain more reliable estimates of an average load for that cell.

Relying on the intuition that air conditioning energy use is "linked" to adjacent hours and climatic conditions, we used an algorithm based on a parametric model to smooth the surface of the raw time-temperature matrix. For this smoothing, we assumed that, for a given hour, average central air conditioner load increases monotonically with THI. Further, we assumed that there is a finite maximum energy demand. (This demand would normally occur at a level far higher than any observed in the data. The assumption does have some intuitive appeal, since demand is limited by population and appliance inventory.) This maximum demand is invariant across the day, but, for various periods of the day, different (possibly infinite) levels of THI are necessary to bring about that maximum demand. Under these assumptions, we modeled average central air conditioner demand for any given hour as being predicted by a maximum demand level that is weighted by a two-parameter Weibull probability distribution on THI (see Ruderman et al. 1989 for details). ${ }^{3}$

Figure 5-2 shows the smoothed version of the raw matrix depicted in Figure 5-1. Although the smoothing procedure extrapolates loads for time-temperature bins for which no data were observed, we only depict loads for hour-THI bins for which data were observed for purposes of comparison to Figure 5-1.

The smoothed time-temperature matrix can be used to generate a day's load shape based on 24 hourly values of THI, with each hourly value a predicted load in energy units. The resulting load shape can then be normalized (as it is for the purposes of the CEC space-conditioning demand model) by first summing the predicted hourly loads and then dividing each hourly load by that sum, so that the 24 rescaled hourly loads add up to one.

In Chapter 4 we discussed the use of backcasts to assess the time-temperature matrix. Tables 5-1, 5-2, and 5-3 summarize results for the measures of backcast fit for CEC Regions 2, 3, and 4 respectively. We report the mean, median, standard deviation and mean absolute value of each measure. We evaluated the performance of the matrix considering the hottest summer days as well as the entire summer seasonal. The hottest days were selected as the days in the highest $5 \%$ of degree-days of THI (THI-DD; see appendix A). We believe that the results of the hottest days are of most importance: summers typically include many relatively cool days on which little cooling energy use is expected. Summaries for the entire summer are included for completeness. 4 closer examination of our results for the entire summer indicated poor predictive capability for these cool days in general, in part because small absolute differences in recorded energy use on these days can result in large differences in the normalized load shapes used for comparison. Predictions for these cool days can have considerable influence on the Summer summaries.

\footnotetext{
${ }^{3}$ Other alternative include non-parametric smoothing algorithms. Also, the more sample data available to model the raw time-temperature matrix, the less justified smoothing may be.
} 
For CEC Region 2 (Sacramento weather station), the peak hour of the backcast load shape is the same as the peak hour of the sample load shape for $27 \%$ of the 920 summer days examined, and for $23 \%$ of the hottest five percentile summer days. For the hottest days the matrix tends to predict peak loads an hour too early (32\%). Peak load is predicted an average of $2.2 \%$ (of total daily load) too high for both the summer and hottest days. The average production error ("mean absolute" in the table) for peak load is $3.8 \%$ for summer days and $2.2 \%$ for the hottest days. The median difference between sample and backcast peaks is $1.7 \%$ for summer days and $2.0 \%$ for the hottest days. With regard to loads at the time of system peak (4 p.m.), the average Summer load is over-predicted by $2.6 \%$, while the load on the hottest days is over-predicted by $1.4 \%$. It is difficult to draw specific conclusions from RMSE. The normalized RMSE is on average, considerable lower for the hottest days than for the entire summer.

For CEC Region 3 (Fresno weather station), the peak hour of the backcast load shape is the same as the peak hour of the sample load shape for $31 \%$ of all summer days and $27 \%$ of the hottest days. Normalized peak loads are predicted quite accurately. They are on average high by $1 \%$ for the summer and high by less than $1 \%$ for the hottest days. Load predictions for 4 p.m. are similarly accurate. As was found for Region 2, RMSE is lower for the hottest days than it is for the entire Summer.

For CEC Region 4 (San Jose weather station) the timing of the peak hour of the backcast load shape matches the observed peak hour on about one-fourth of summer days (26\%). The time of peak tends to be predicted one hour early for both the entire summer and for the hottest days. The magnitude of the predicted peak is, on average, high by $1.6 \%$ both for the summer and the hottest days, with the median difference also too high, by $1.2 \%$ and $1.8 \%$ for the summer and hottest days respectively. The average prediction error is higher for summer days (3.3\%) than the average prediction error for the hottest days $(2.1 \%)$. The loads at 4 p.m. are high, an average of about $2 \%$ for both the summer and the hottest days. As with the other regions, RMSE is lower for the hottest days than is for the entire summer.

In summary, Tables 5-1 through 5-3 indicate regional differences in the performance of the grand matrix, with relatively good performance for Region 3, and poorer performance and substantial bias in peak prediction for Region 2 and Region 4. Appendix $F$ addresses regional differences in matrix performance. Overall, predictions for the hottest days are considerable better than predictions for other summer days.

The measures give an indication of how well the time-temperature model fits the sample load data but must be interpreted with caution. First, the same data used to construct the timetemperature matrix are used to evaluate fit. This may lead to somewhat exaggerated description of goodness of fit. The sub-sampling strategies examined in Appendix F begin to address this issue.

Second, the backcast load shape is based on long-term, system-wide averages because many dates from each of the five stations may have an hour assigned to a given THI-hour bin. That is, the single-date, single-region loads falling into a particular hour-THI bin are selected on the 
basis of the hour-THI only. For a given set of weather conditions, the sample data shows considerable variation. The backcast load shape, which is based on long-term region-wide averages, cannot capture this variation, nor should it necessarily, since our objective is to predict system, not sample, loads. In effect, we compare time-temperature cell loads, which are based on long-term system-wide averages, with single-date single-region averages (as moderated by loads for other hours of the day for the normalized load shape comparisons). Our sample-to-backcast comparisons have been evaluated in relationship to this inherent variance, by considering overall performance rather than the performance for any single day. To the extent that accurate forecasts for individual days (system peak days, for example) are of greater importance, different modeling procedures may be appropriate.

These findings underlie what we believe to be important, but not well appreciated, trade-offs in accuracy between the different forecasting applications of the CEC time-temperature matrix (and, we believe, the PG\&E model). That is, while forecasting system peak demands remains critically important for the planning process, other forecast quantities (such as hourly loads on non-system peak days and minimum load conditions) have increased in importance. Even for the system peak day, there are trade-offs in accuracy between forecasting the absolute $\mathrm{kW}$ value of the peak for the space cooling end use, the timing of that peak, and the load that is coincident with the time of the system peak. At the present time, the relative importance of these trade-offs has not been assessed. 


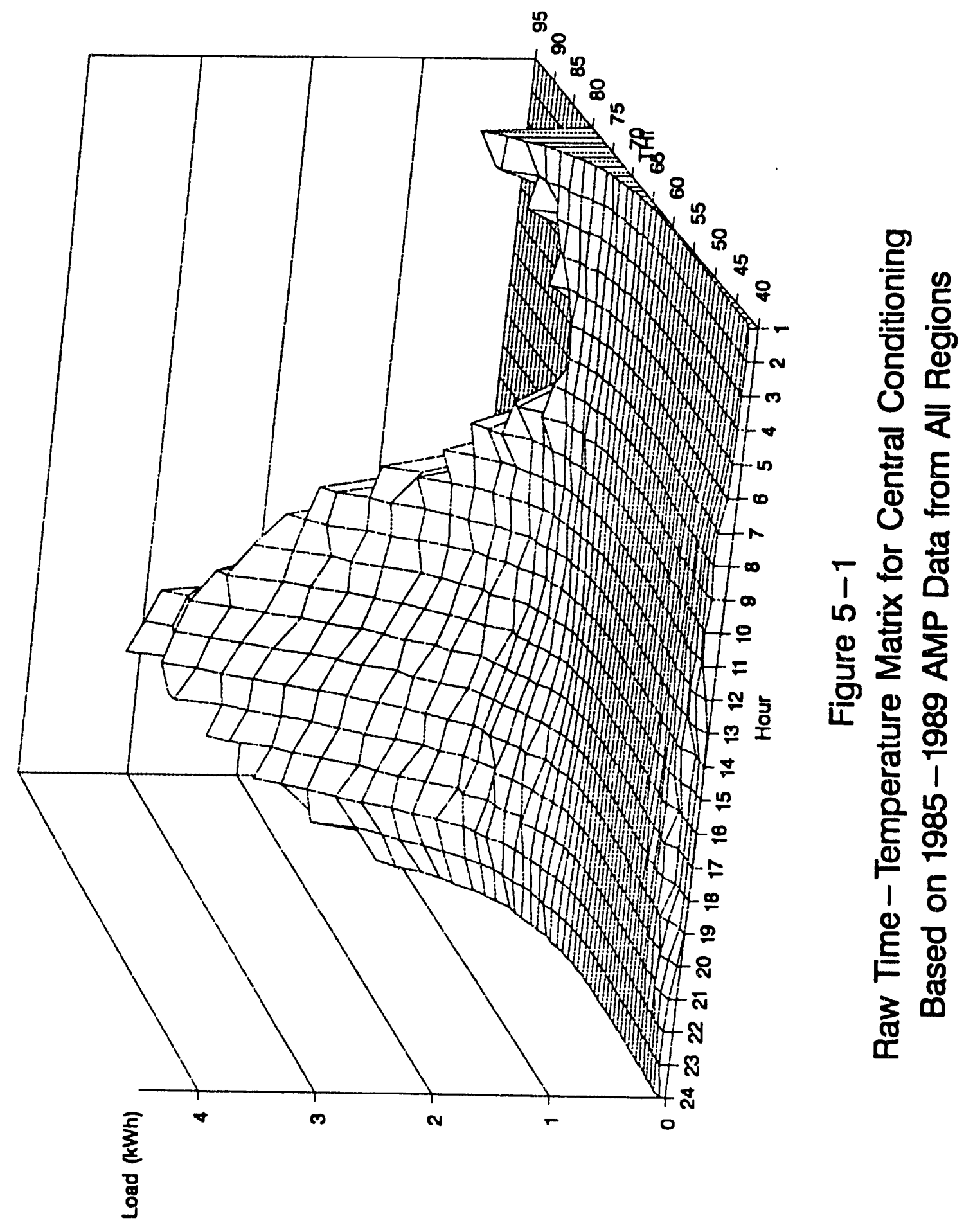




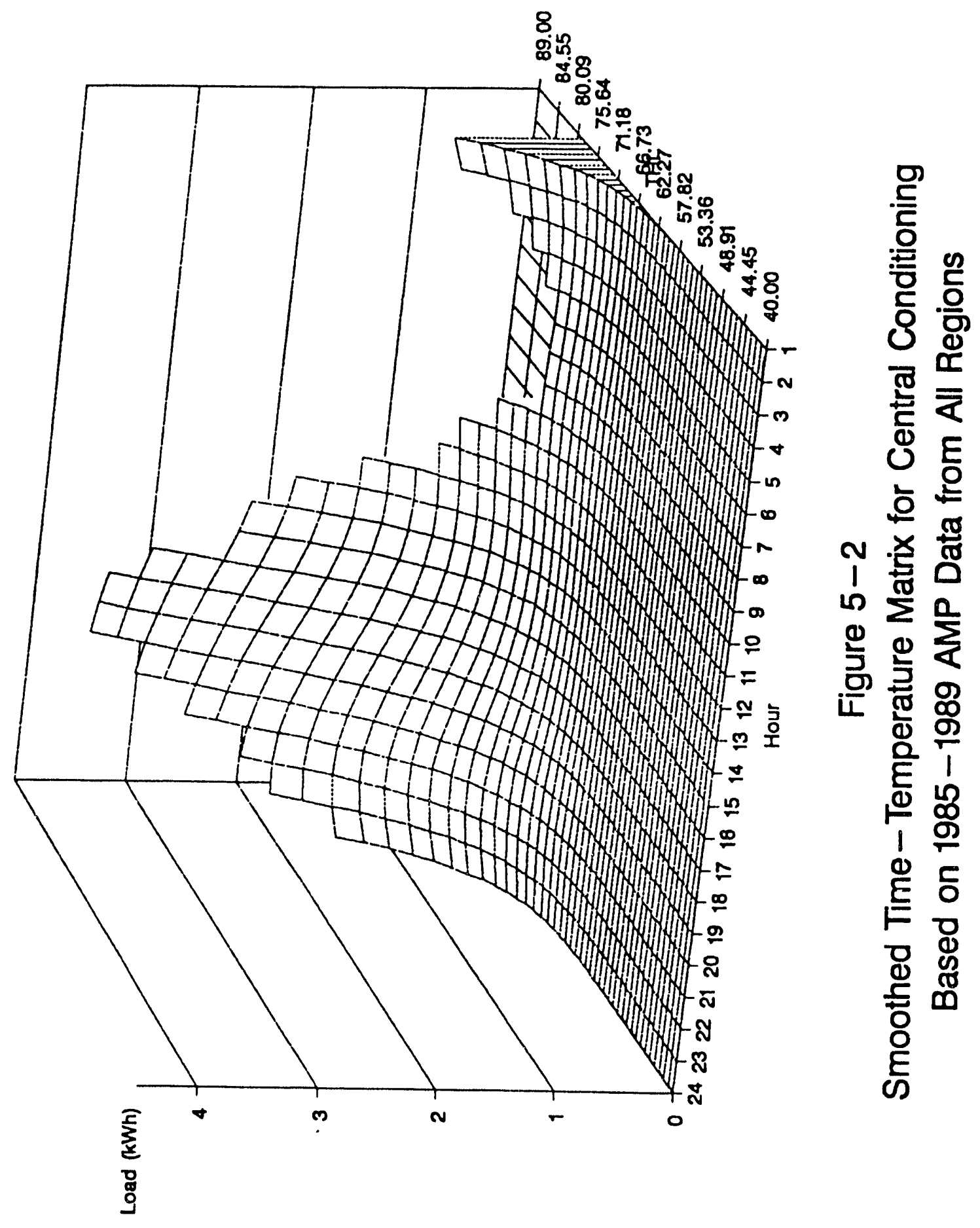


Table 5-1

Summary of Measures from Comparisons of Daily Backcast Load Shape to Sample CEC Region 2

Timing of Paak Hour"

\% same $\ldots \ldots \ldots \ldots \ldots \ldots \ldots \ldots \ldots$

\% 1 hour late .................

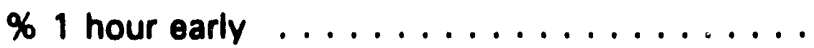

$\%>2$ hours off $\ldots \ldots \ldots \ldots \ldots \ldots \ldots$

Magnitude of Peak (samp/e-backcast)

$\operatorname{mean} \ldots \ldots \ldots \ldots \ldots \ldots \ldots \ldots$

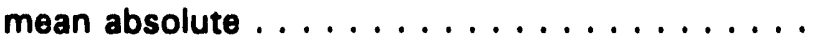

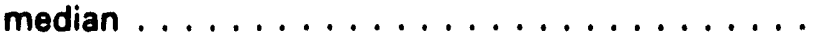

standard deviation

Magnitudo of 4 p.m. Losd (samplo-backcast)

$\operatorname{mean} \ldots \ldots \ldots \ldots \ldots \ldots \ldots \ldots \ldots$

mean absolute . . . . . . . . . . . .

median . . . . . . . . . . . . . . . .

standard deviation

$\begin{array}{cc}\text { Summor } & \text { Hottest } 5 \% \\ 27 & 23 \\ 18 & 28 \\ 21 & 32 \\ 20 & 4\end{array}$

$-0.022$

$-0.022$

0.038

0.022

0.017

0.047

$-0.020$

0.013

$-0.026$

$-0.014$

0.037

0.017

$-0.021$

$-0.014$

0.042

0.015

RMSE

$\operatorname{mean} \ldots \ldots \ldots \ldots \ldots \ldots \ldots \ldots$

$\operatorname{median} \ldots \ldots \ldots \ldots \ldots \ldots \ldots \ldots \ldots$

0.029

0.023

0.017

0.013

0.013

0.003

920

- backcast rolative to sample

- in terms of THI-DD (s00 toxt) 
Table 5-2

Summary of Measures From Comparison of Daily Backcast Load Shape to Sample CEC Region 3

Timing of Paak Hour *

\% same $\ldots \ldots \ldots \ldots \ldots \ldots \ldots \ldots \ldots \ldots$

\% 1 hour late $\ldots \ldots \ldots \ldots \ldots \ldots \ldots \ldots$

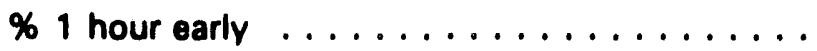

$\%>2$ hours off $\ldots \ldots \ldots \ldots \ldots \ldots \ldots$

Magnitude of Pask (sample-backcast)

$\operatorname{mean} \ldots \ldots \ldots \ldots \ldots \ldots \ldots \ldots \ldots$

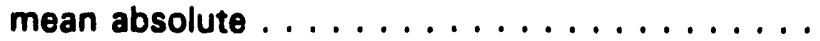

median ....................

standard deviation $\ldots \ldots \ldots \ldots \ldots \ldots \ldots$

Magnitude of 4 p.m. Load (samplo-backcast)

$\operatorname{mean} \ldots \ldots \ldots \ldots \ldots \ldots \ldots \ldots \ldots$

mean absolute $\ldots \ldots \ldots \ldots \ldots \ldots \ldots \ldots$

$\operatorname{median} \ldots \ldots \ldots \ldots \ldots \ldots \ldots \ldots \ldots$

standard deviation
Summer

31

22

16

19
Hottest 5\%"*

27

25

23

10

$\begin{array}{rr}-0.010 & -0.004 \\ 0.026 & 0.007 \\ -0.001 & -0.004 \\ 0.037 & 0.007\end{array}$

RMSE

mean $\ldots \ldots \ldots \ldots \ldots \ldots \ldots \ldots \ldots$

0.021

0.007

$\operatorname{median} \ldots \ldots \ldots \ldots \ldots \ldots \ldots \ldots$

0.014

0.017

0.007

standard deviation

$-0.011$

$-0.001$

0.021

0.007

$-0.006$

$-0.001$

0.027

0.008

Number of day pairs

920

48

- backcast relative to sample

- in terms of THI-DD (800 text) 
Table 5-3

Summary of Measures from Comparison of Daily Backcast Load Shape to Sample CEC Region 4

Timing of Pesk Hour *

\% same $\ldots \ldots \ldots \ldots \ldots \ldots \ldots \ldots \ldots$

\% 1 hour late $\ldots \ldots \ldots \ldots \ldots \ldots \ldots \ldots \ldots$

\% 1 hour early $\ldots \ldots \ldots \ldots \ldots \ldots \ldots$

$\%>2$ hours off

Magnitude of Peak (samplo-backcast)

$\operatorname{mean} \ldots \ldots \ldots \ldots \ldots \ldots \ldots \ldots \ldots$

mean absolute $\ldots \ldots \ldots \ldots \ldots \ldots \ldots \ldots$

$\operatorname{median} \ldots \ldots \ldots \ldots \ldots \ldots \ldots \ldots \ldots$

standard deviation
Summer

26

15

26

17
Hottest 5\%"*

30

10

40

3

Magnitude of 4 p.m. Load (samplo-backcast)

$\operatorname{mean} \ldots \ldots \ldots \ldots \ldots \ldots \ldots \ldots \ldots$

$-0.022$

$-0.016$

$-0.016$

0.033

0.021

$-0.012$

$-0.018$

0.042

0.021

mean absolute $\ldots \ldots \ldots \ldots \ldots \ldots \ldots \ldots$

0.033

$-0.020$

$-0.021$

0.022

0.033

$-0.018$

standard deviation

RMSE

$\operatorname{mean} \ldots \ldots \ldots \ldots \ldots \ldots \ldots \ldots$

median . . . . . . . . . . . . . .

standard deviation

0.025

0.014

0.021

0.014

0.014

0.004

Number of day pairs

735

- backcast rolative to samplo

$\cdots$ in terms of THI-DD (seo toxt) 


\section{Chapter 6 \\ Cooling Electricity Use Analysis for PG\&E Load Shape Model}

The basis of PG\&E's load shape forecasts for cooling end uses is a set of load curves corresponding to combinations of day type and average daily temperature and a set of weather response functions (WRFs) that are used to scale the load curves. These load curves and WRFs are used along with weather data as inputs to the load shape forecasting model, HELM. We developed a set of load curves and a set of WRFs using the 1985-1989 AMP data, based on the functional form of the WRFs and the load curve definitions developed previously by PG\&E. The methods and results of this development are discussed in this section.

PG\&E's model for air conditioning demand expresses daily load as a function of a weather index, which we call WAVGTEMP. Based on previous in-house analysis, PG\&E defined WAVGTEMP as a fixed function of daily average temperature on a given day and the two previous days:

$$
W A V G T E M P[i]=0.1 * A V G T E M P[i-2]+0.2 * A V G T E M P[i-1]+0.7 * A V G T E M P[i]
$$

where AVGTEMP[i] is the average of the 48 half-hourly temperatures reported for that day. Air conditioning demand is modeled using linear least squares regression as a function of WAVGTEMP in linear and quadratic terms:

$$
D E M A N D=\alpha_{0}+\alpha_{1} * \text { WAVGTEMP }+\alpha_{2} * \text { WAVGTEMP }{ }^{2}
$$

Regression coefficients are estimated separately for Zones R, S, and X. The regressions are based only on summer (June through September) days. We estimated coefficients for a weather response function of PG\&E's regression equation (shown above) for each Zone $R, S$, and $X$, using all five years of AMP data. We also computed coefficient WRF coefficients based on 1989 data only, for comparison to PG\&E's original WRF coefficients which were also computed only on data from 1989.

To compute the coefficients, we determined zone average daily central air conditioner load and zone average daily room air conditioner load from the AMP data for each summer day of 19851989. We computed the value of the average temperature function WAVGTEMP for PG\&E's Fresno, Sacramento, and San Ramon weather stations. We then regressed WAVGTEMP and the square of WAVGTEMP on daily demand using ordinary linear least squares regression. 
Table 6-1 shows the coefficient estimates for the weather response function for each zone along with standard errors for the estimates and the coefficient of determination $\left(r^{2}\right)$ for the model. The regressions explain 95 percent of the variance of summer daily energy use about the mean for Zone R, 84 percent for Zone S, and 85 percent for Zone X. We found that our estimated coefficients differed from PG\&E's by a nearly constant scaling factor across the three coefficients (the factor depending on the zone), implying that the PG\&E and LBL WRFs were based on different scaling factors for daily energy. Another possible source of difference between LBL and PG\&E regressions is that LBL daily energy estimates were formed as the sum of scaled central air conditioner and room air conditioner loads whereas PG\&E may have used a different procedure.

An issue of interest to both CEC and PG\&E is whether it is appropriate to use distinct weather response functions for peak load days rather than using the same weather response functions developed for the entire air conditioning season. Although the levels of percent variance explained $\left(r^{2}\right)$ are nominally impressive, good energy predictions for the relatively large number of low-load, mild-weather days contribute substantially to this measure of fit. In the future, it may be appropriate to further stratify regressions on weather severity, instead of using all summer days, to arrive at a single weather response function for each zone; that is, days could be stratified according to weather severity (weighted average daily temperature, for example), with separate regressions computed for each stratum. To the extent that high and peak load days are of interest, it seems reasonable to base evaluation of such models on their performance in predicting loads for the hottest days. One approach would omit the mild-weather days from the regression.

There are other possibilities for determining air conditioning demand response to weather while retaining the basic form of the WRFs currently in use. These are: computing regressions for weekends and weekdays separately, computing regressions for central air conditioner separately, estimating weights for terms of the weighted average daily temperature index (rather than using prespecified weights), and using some measure of daily temperature extreme in addition to (or instead of) daily temperature average. Other alternatives include using a different form for the regression, for example, using transformations for WAVGTEMP other than the quadratic transformation used in the current WRFs.

To allocate daily energy to the hours of the day, PG\&E specifies load curve bins by geographic area (PG\&E Zones $\mathrm{R}, \mathrm{S}$, and $\mathrm{X}$ ), daily average temperature, and day type. Table 6-2 shows the bin definitions used by PG\&E. For their load shape model, PG\&E identifies a single cooling end use that represents cooling for all residential buildings (single-family, multi-family, and mobile homes). We developed two sets of load curves, one for central air conditioning, and a separate set for a combined cooling end use (averaging central and room air conditioners).

Load data were first aggregated to PG\&E Zone according to zone assignments provided by PG\&E. Numbers of central and room air conditioners metered in each zone are given in Table 3-2. Based on day type (Weekday, or Weekend/Holiday) and weather data reported at the PG\&E weather station assigned to the zone (Fresno weather for Zone R, Sacramento weather 
for Zone S, and San Ramon weather for Zone X), each summer day (June through September) was assigned to a bin. An average load curve was computed by end use for each of these bins by averaging over days and residences to each hour. Because of their late arrival, PG\&Edeveloped sample weights were not used in our analysis. Load curves were energy-normalized so that each hourly value expresses that hour's contribution to total daily energy consumption.

Figures 6-1 to 6-6 show the normalized central air conditioner load curves for each bin for zones $\mathrm{R}, \mathrm{S}$, and $\mathrm{X}$, with weekday and weekend curves appearing on separate graphs. The data for these load curves are tabulated in Appendix D.

To get an indication of the statistical precision of these load shapes we computed 95 percent confidence limits for the hourly means comprising each binned load shape. Depending on the bin, this entails computing a standard deviation of hourly demand over days which can have somewhat different average temperature, (e.g. in the $70-100^{\circ} \mathrm{F}$ Zone X Weekend bin).

Figure 6-7 shows the weekday load shape corresponding to the hottest temperature bin (daily average temperature $87.5-100^{\circ} \mathrm{F}$ ) for Zone $R$ along with dashed lines connecting the bounds of the hourly confidence limits. The bounds are quite narrow, indicating that the relative precision of the hourly means is high. Figure 6-8 shows the hourly confidence bounds for the Weekend $87.5-100^{\circ} \mathrm{F}$ average daily temperature bin. These bounds are somewhat broader than those for weekday as would be expected because of the smaller number of days falling into this bin. 
Table 6-1

LBL Coefficient Estimates for PG\&E Weather Response Functions

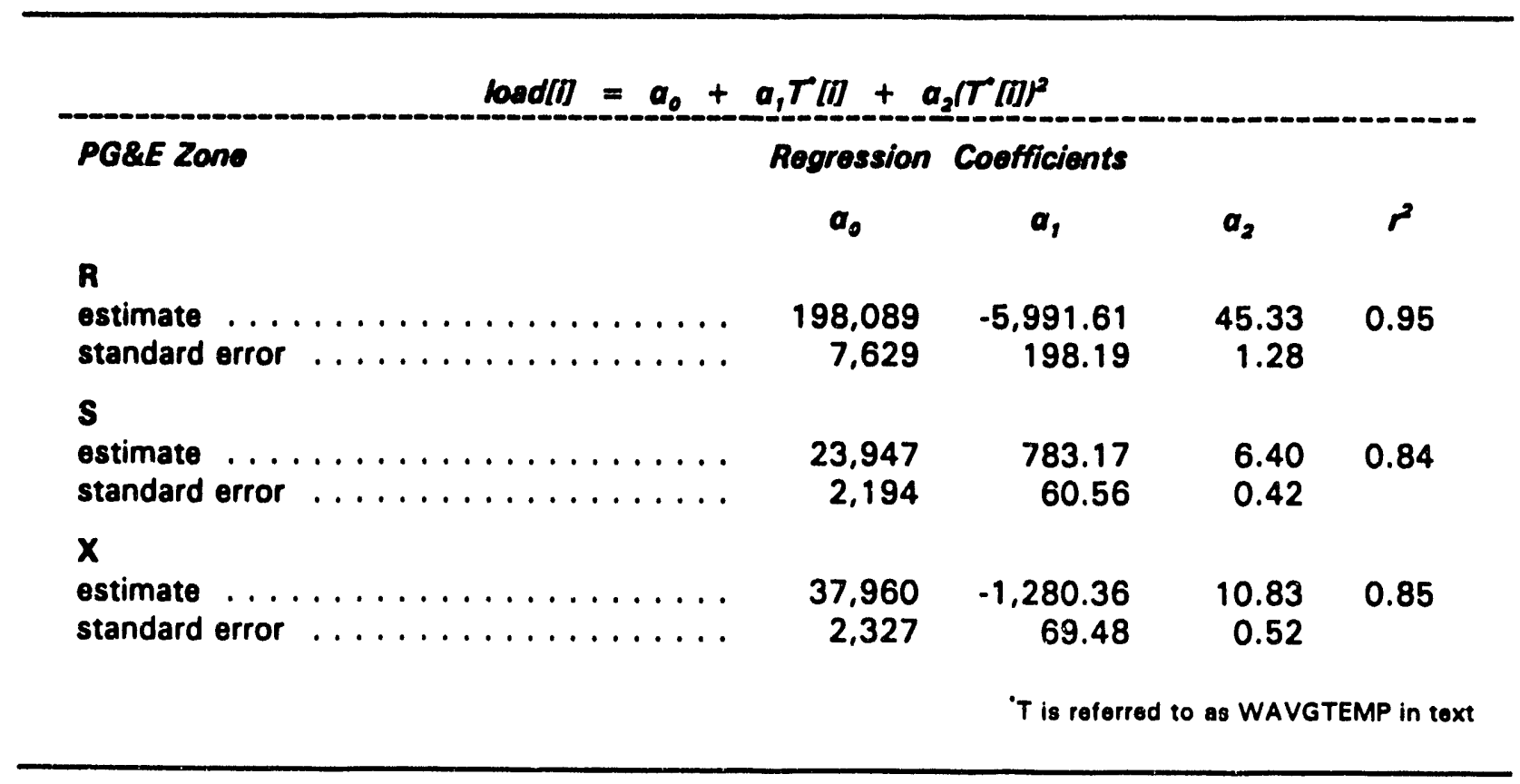


Table 6-2

PG\&E Cooling Load Bins by Zone for Ranges of Average Temperature ( ${ }^{\circ} \mathrm{F}$ )

\begin{tabular}{|c|c|c|}
\hline $\begin{array}{l}\text { ZONE } \\
\mathbf{R} \ldots \ldots \ldots \ldots \ldots \ldots\end{array}$ & $\begin{array}{l}\text { WEEKDAY } \\
0.0-66.2 \ldots \ldots \ldots \ldots \\
66.2-75.0 \\
75.0-80.0 \\
80.0-85.0 \\
85.0-87.5 \\
87.5-100.0\end{array}$ & $\begin{array}{l}\text { WEEKEND } \\
0.0-66.2 \\
66.2=75.0 \\
75.0-80.0 \\
80.0-85.0 \\
85.0=87.5 \\
87.5-100.0\end{array}$ \\
\hline $\mathbf{s} \ldots \ldots \ldots \ldots \ldots \ldots$ & $\begin{array}{l}0.0-62.1 \ldots \ldots \ldots \ldots \\
62.1-70.0 \\
70.0-75.0 \\
75.0-80.0 \\
80.0-85.0 \\
85.0 \cdot 100.0\end{array}$ & $\begin{array}{l}0.0-62.1 \\
62.1-70.0 \\
70.0-75.0 \\
75.0-100.0\end{array}$ \\
\hline$x \ldots \ldots \ldots \ldots$ & $\begin{array}{l}0.0-58.6 \ldots \ldots \ldots \ldots \\
58.6-67.5 \\
67.5-72.5 \\
72.5-77.5 \\
77.5-100.0\end{array}$ & $\begin{array}{l}0.0-58.6 \\
58.6-70.0 \\
70.0-100.0\end{array}$ \\
\hline
\end{tabular}




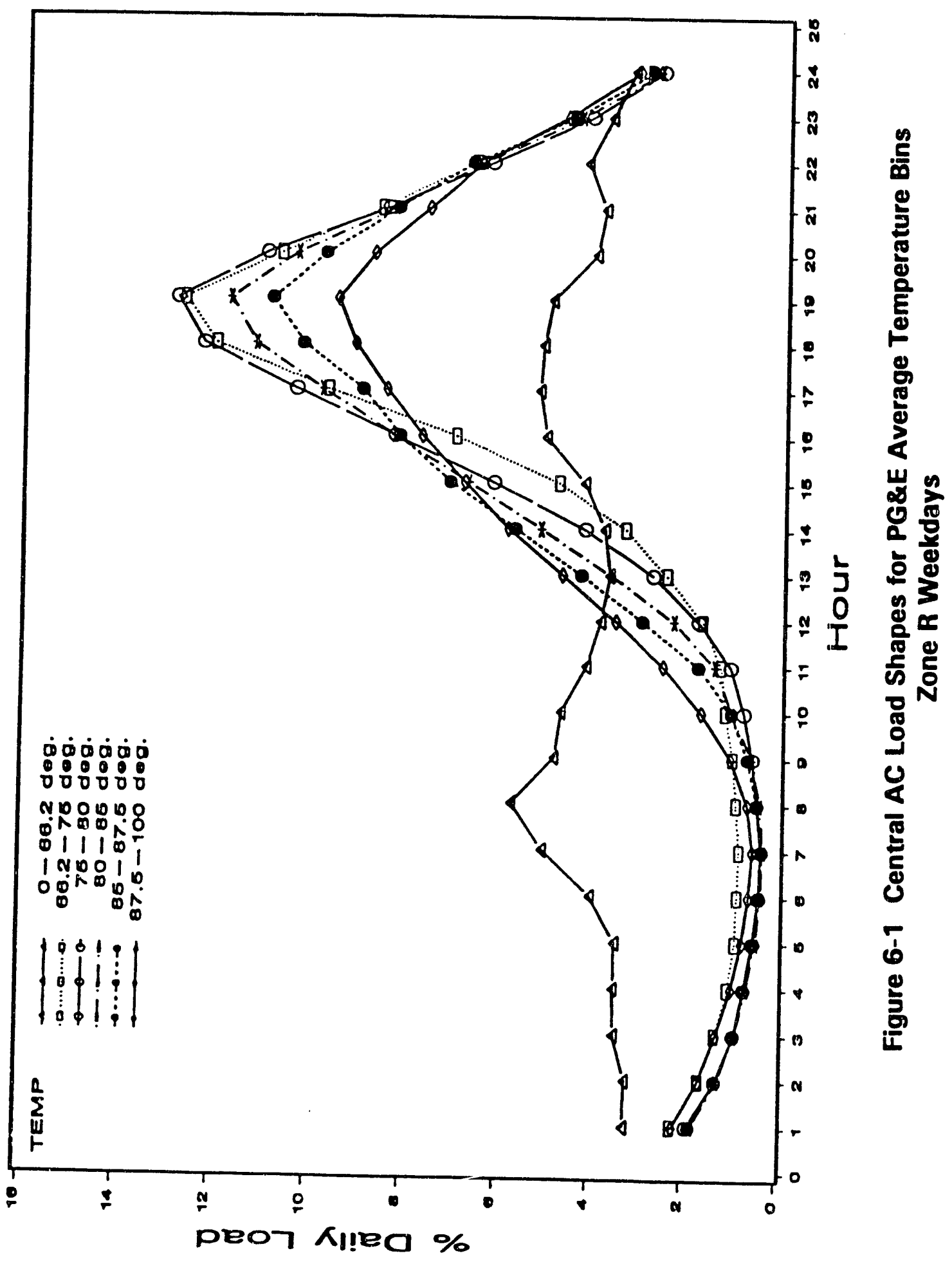




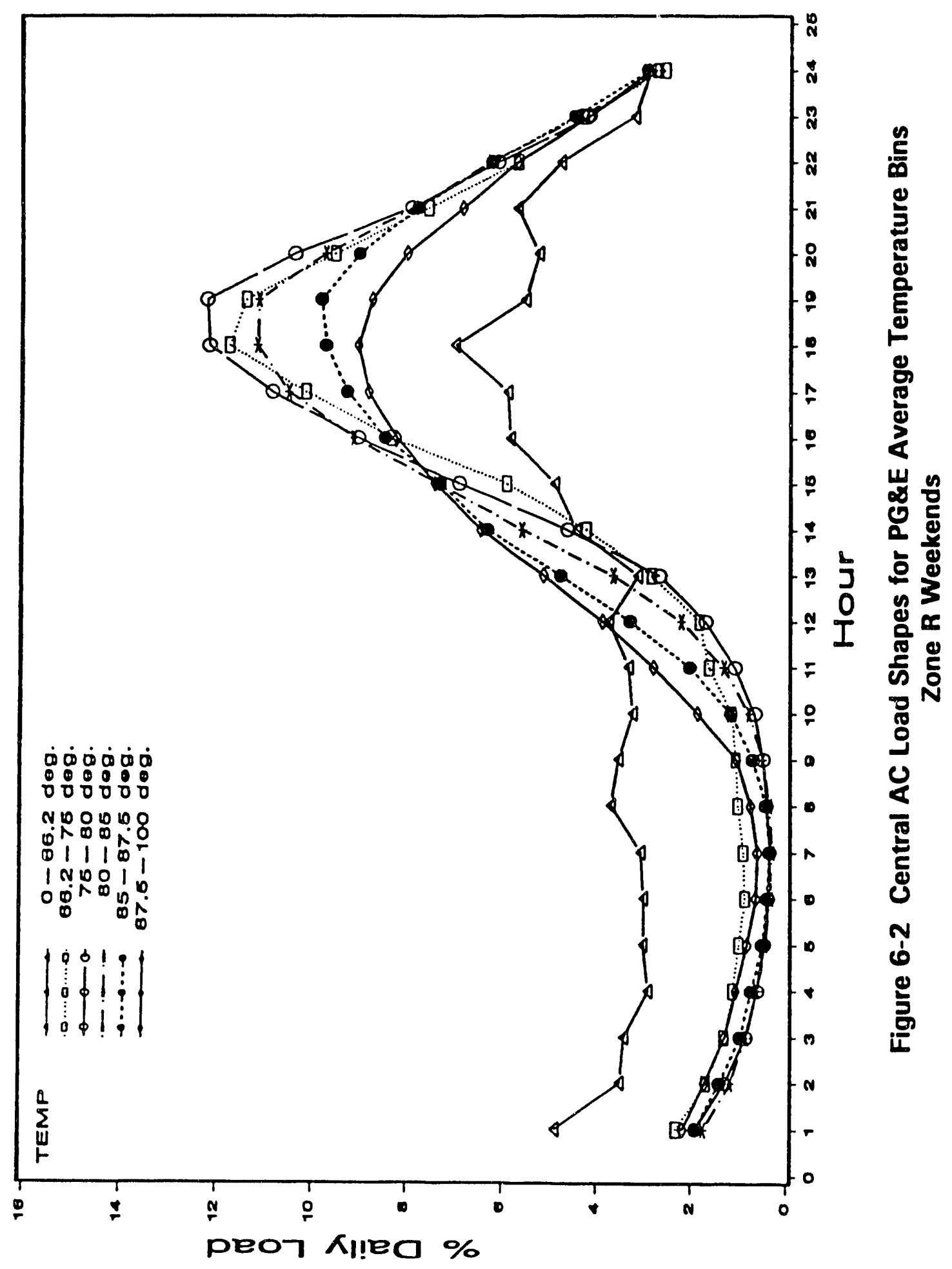




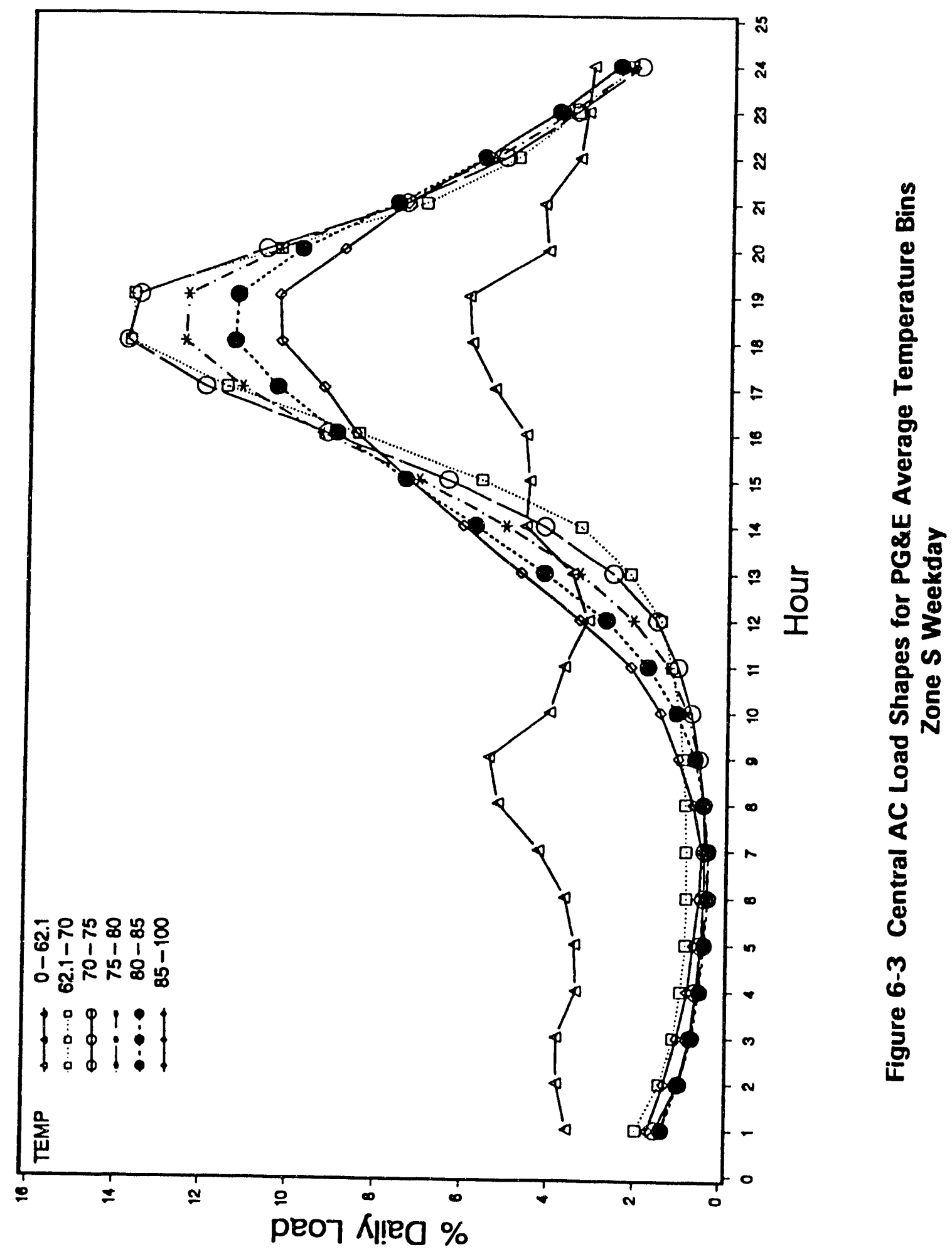




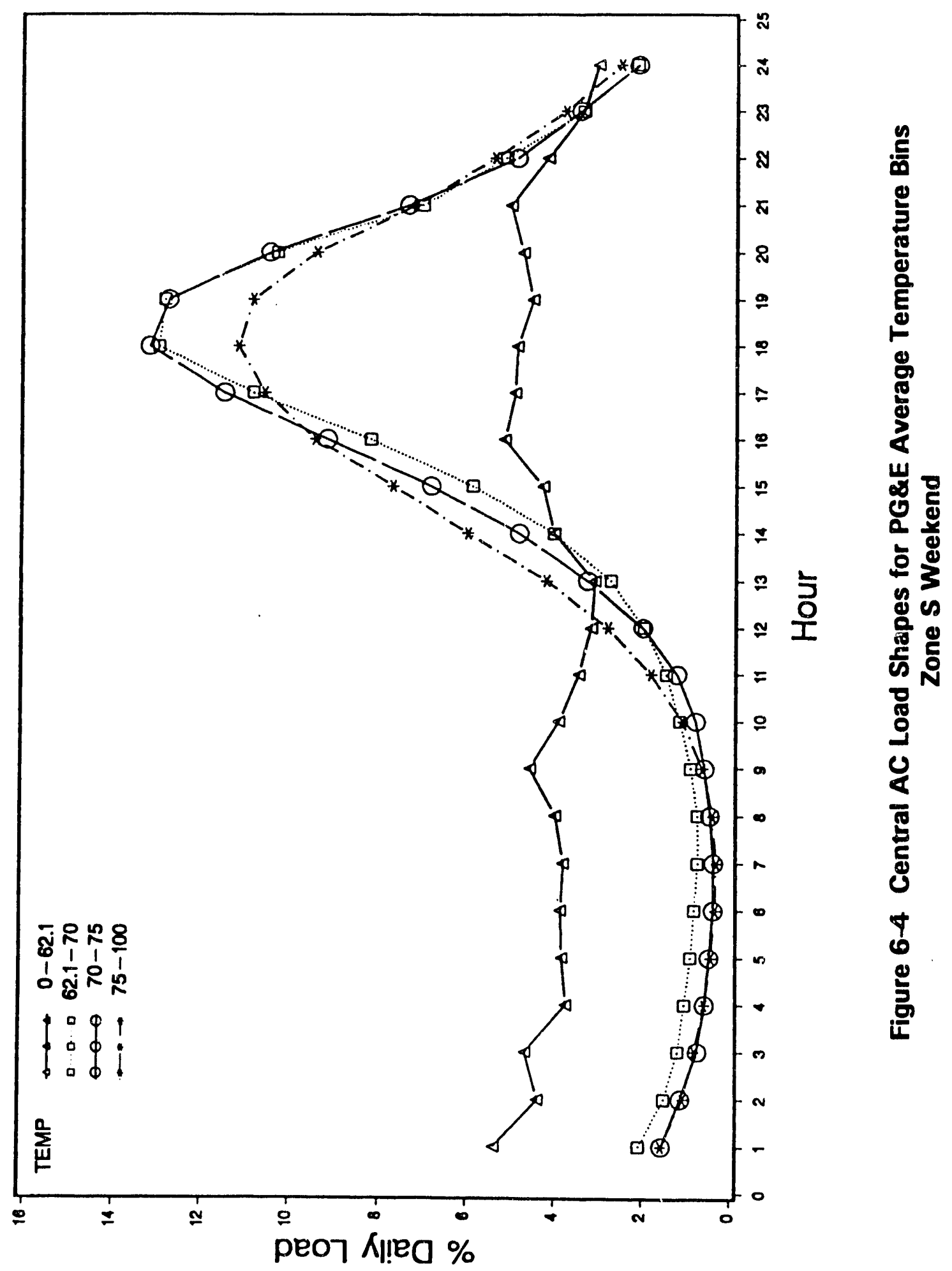




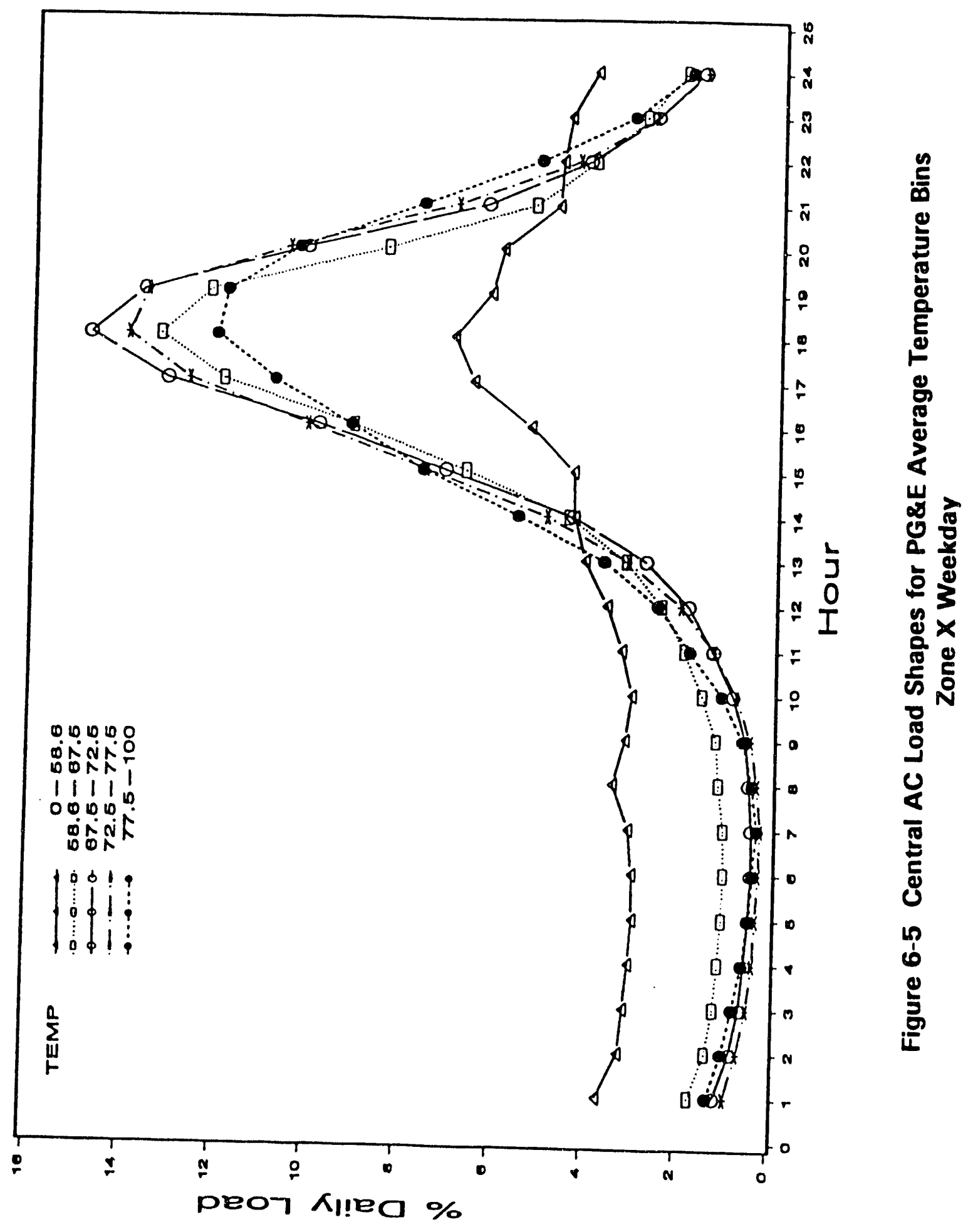




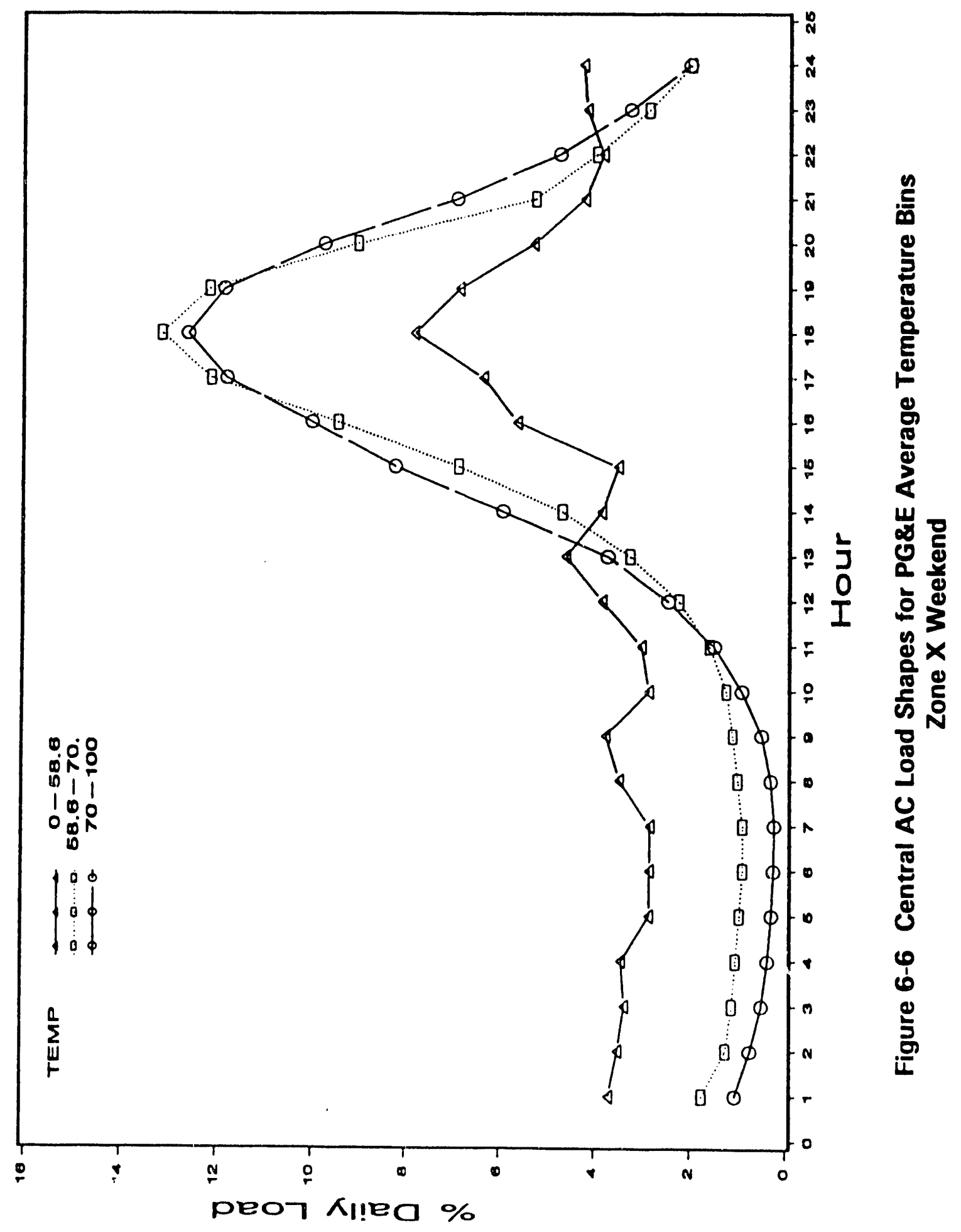




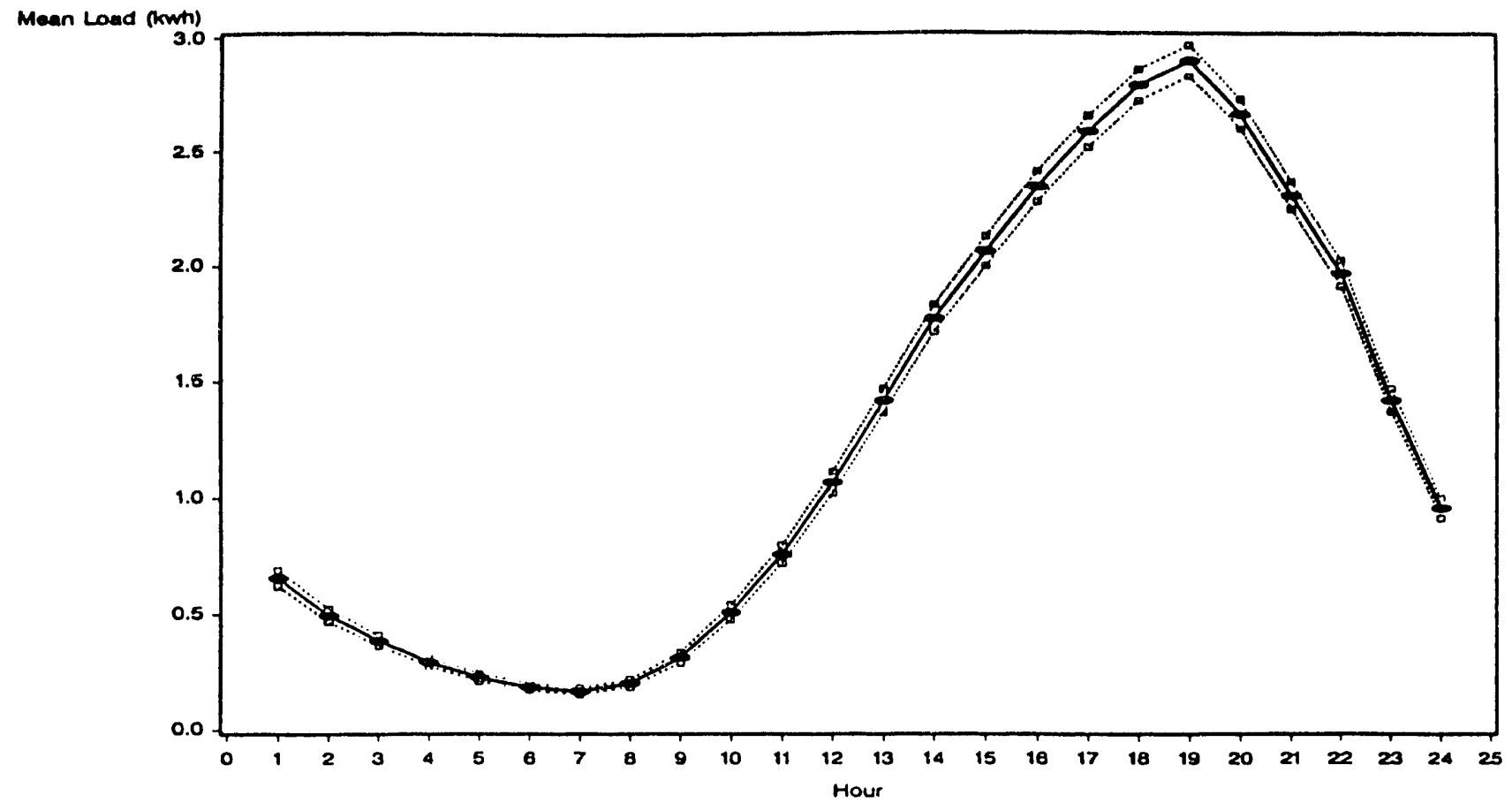

Figure 6-7. Cooling Load Shape for One R 87.5-100\% F Weekday Bin with 95\% CI on Hourly Means

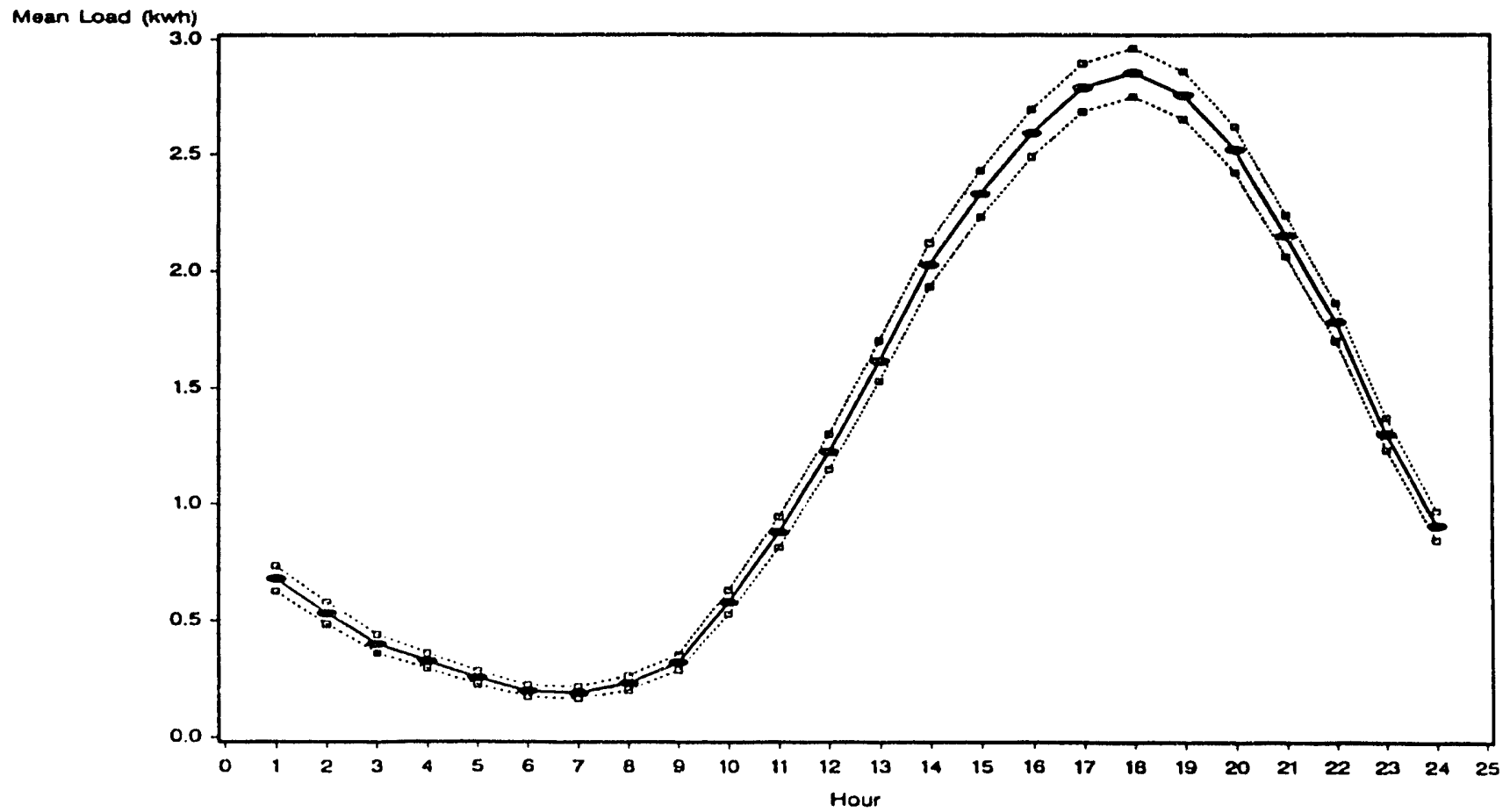

Figure 6-8. Cooling Load Shape for Zone R 87.5-100\% Feekend Bin with 95\% $\mathrm{Cl}$ on Hourly Means 


\section{Chapter 7 \\ Non-Space-Conditioning Data Analysis for CEC Peak Demand Model}

CEC's residential peak demand model uses fixed allocation factors defined by day type and season to allocate the annual total energy consumed by non-space conditioning end uses to each day of the year. Hourly energy use is determined by using normalized daily load shapes to allocate daily energy use to each hour. In this section we present allocation factors and average daily load shapes by season and day type, based on the three years of AMP non-conditioning data that we studied. We present the average daily load results graphically, with tabular summaries in Appendix E.

An end use's allocation factor (AF) for period $i$, day type $j$, is defined as,

$A F\left[i_{v}\right]=$ average daily load $\left[i_{j}\right]$ /average annual daily load.

We calculated seasonal allocation factors for three day types (Weekday, Weekend, and All Days) for each of the five non-conditioning end uses analyzed in this study. For these computations, we defined Winter as December through February, Spring as March through May, Summer as June through September, and Fall as October and November. The averages were taken over all three years of data (see Table 3-7).

Table 7-1 shows the seasonal allocation factors for each day type by end use. Seasonal ratios of average weekday energy use to average weekend daily energy use are also tabulated. Annual weekday-to-weekend energy use ratios are reported in Table 7-2.

Clothes dryer, water heater, and cooking loads are relatively high in winter and low in summer, while refrigerator load is relatively high in summer and low in winter. The kitchen circuit end use shows little seasonal variation, with loads slightly (about six percent) higher in summer than on average.

Mean weekday energy use is slightly below mean weekend energy use for refrigerator, water heater, and kitchen circuit, with little seasonal variation. Mean energy use for cooking is on average about 15 percent lower on weekdays than on weekends, with somewhat more seasonal variation than the aforementioned end uses. Weekday-to-weekend ratios for the cooking end use range from 0.785 for Fall to 0.894 for Winter. Mean energy use for clothes dryer is on average about 15 percent lower on weekday than on weekends, and the relative difference between weekday and weekend energy use is least pronounced in the summer (ratio 0.846) and most pronounced in the fall (ratio 0.775). 
We also computed allocation factors for the end uses on a monthly basis for each of three day types. These factors, and monthly weekday-to-weekend energy use ratios, are tabulated in Appendix F. Because months comprise fewer data than seasons, fewer observations contribute to each monthly mean than would contribute to a seasonal mean. As a result, differences among the monthly factors are less reliable indicators of actual (i.e., system-wide) differences in energy use than are the seasonal factors.

We derived average daily load shapes for non-conditioning end uses by day type for two seasons, Summer (June through October) and Winter (November through May). Figures 7-1 through 7-5 show these four average daily load shapes for each end use. The load shapes are represented on an energy-normalized scale, with hourly loads expressed as a percentage of daily energy use. Weekday load shapes differ noticeably from weekend load shapes for three of these end uses.

The sample average weekday load shapes for cluthes dryer are different than the weekend load shapes. The load shapes for both Summer and Winter weekends have highest loads at hours 11 and 12, with each of these two hours contributing about 8 percent to total daily use. The weekday load shapes peak higher and later, with highest daily loads at hours 12 and 13 each contributing about 9 percent to total daily energy use. For a given day type, the observed Summer and Winter load shapes have similar but not identical patterns.

Weekday cooking load shapes also differ from weekend cooking load shapes. Both Winter and Summer load shapes are highest at hours 18 and 19 (hour 18 in the Winter, hours 18 and 19 in the Summer), but the weekday loads are considerably more concentrated on these peak hours than are the weekend loads.

The four average daily load shapes for kitchen circuit are nearly identical, each gradually increasing between 9 a.m. and the peak load hour $7 \mathrm{p.m}$. The four load shapes for refrigerator are also nearly identical, each with highest loads at hours 19 and 20.

The water heater load shapes each have two peaks. For weekdays, the morning peak is at hour 8 , and the lower, evening peak is at hours 19 and 20 . On weekends, the morning peak occurs later than on weekdays, at hours 9 and 10, with the weekend load shape less concentrated at the morning peak than is the weekday load shape. 
Table 7-1

Seasonal Allocation Factors Non-Conditioning End Uses

\begin{tabular}{|c|c|c|c|c|}
\hline SEASON & WEEKDAY & WEEKEND & ALL DAYS & WEEKDA YIVEEEKEND \\
\hline $\begin{array}{l}\text { Clothes Dryer } \\
\text { Winter . . . } \\
\text { Spring . . . . } \\
\text { Summer . . } \\
\text { Fall . . . . . }\end{array}$ & $\begin{array}{l}1.081 \\
0.918 \\
0.817 \\
0.943\end{array}$ & $\begin{array}{l}1.362 \\
1.180 \\
0.965 \\
1.217\end{array}$ & $\begin{array}{l}1.169 \\
0.994 \\
0.863 \\
1.028\end{array}$ & $\begin{array}{l}0.794 \\
0.778 \\
0.846 \\
0.775\end{array}$ \\
\hline $\begin{array}{l}\text { Cooking } \\
\text { Winter . . . } \\
\text { Spring . . . . } \\
\text { Summer . . } \\
\text { Fall . . . . . }\end{array}$ & $\begin{array}{l}1.044 \\
0.937 \\
0.874 \\
0.955\end{array}$ & $\begin{array}{l}1.154 \\
1.273 \\
1.087 \\
0.978\end{array}$ & $\begin{array}{l}1.116 \\
0.981 \\
0.907 \\
1.036\end{array}$ & $\begin{array}{l}0.820 \\
0.863 \\
0.894 \\
0.785\end{array}$ \\
\hline $\begin{array}{l}\text { Kitchen Circuit } \\
\text { Winter . . . } \\
\text { Spring . . . . } \\
\text { Summer . . . } \\
\text { Fall . . . . . }\end{array}$ & $\begin{array}{l}0.954 \\
0.964 \\
1.060 \\
0.975\end{array}$ & $\begin{array}{l}0.973 \\
0.984 \\
1.069 \\
1.013\end{array}$ & $\begin{array}{l}0.960 \\
0.970 \\
1.063 \\
0.987\end{array}$ & $\begin{array}{l}0.980 \\
0.979 \\
0.991 \\
0.962\end{array}$ \\
\hline $\begin{array}{l}\text { Refrigerator } \\
\text { Winter . . . } \\
\text { Spring . . . . } \\
\text { Summer . . . } \\
\text { Fall . . . . . . }\end{array}$ & $\begin{array}{l}0.864 \\
0.947 \\
1.117 \\
0.992\end{array}$ & $\begin{array}{l}0.892 \\
0.978 \\
1.131 \\
1.030\end{array}$ & $\begin{array}{l}0.873 \\
0.956 \\
1.121 \\
1.004\end{array}$ & $\begin{array}{l}0.970 \\
0.968 \\
0.987 \\
0.963\end{array}$ \\
\hline $\begin{array}{l}\text { Water Heater } \\
\text { Winter . . . } \\
\text { Spring . . . . } \\
\text { Summer . . . } \\
\text { Fall . . . . . . }\end{array}$ & $\begin{array}{l}1.221 \\
1.017 \\
0.795 \\
0.996\end{array}$ & $\begin{array}{l}1.262 \\
1.065 \\
0.808 \\
1.035\end{array}$ & $\begin{array}{l}1.233 \\
1.031 \\
0.799 \\
1.008\end{array}$ & $\begin{array}{l}0.968 \\
0.955 \\
0.984 \\
0.963\end{array}$ \\
\hline
\end{tabular}

Table $7-2$

Energy Use Ratios Non-Conditioning End Uses

APPLIANCE

Clothes Dryer . . . . . . . . . . . . . .

Cooking $\ldots \ldots \ldots \ldots \ldots$

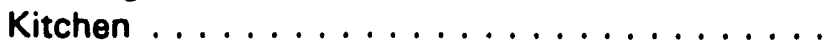

Refrigerator ..................

Water Heater
WEEKDAYIWEEKEND ENERGY USE

0.796

0.854

0.981

0.978

0.979 


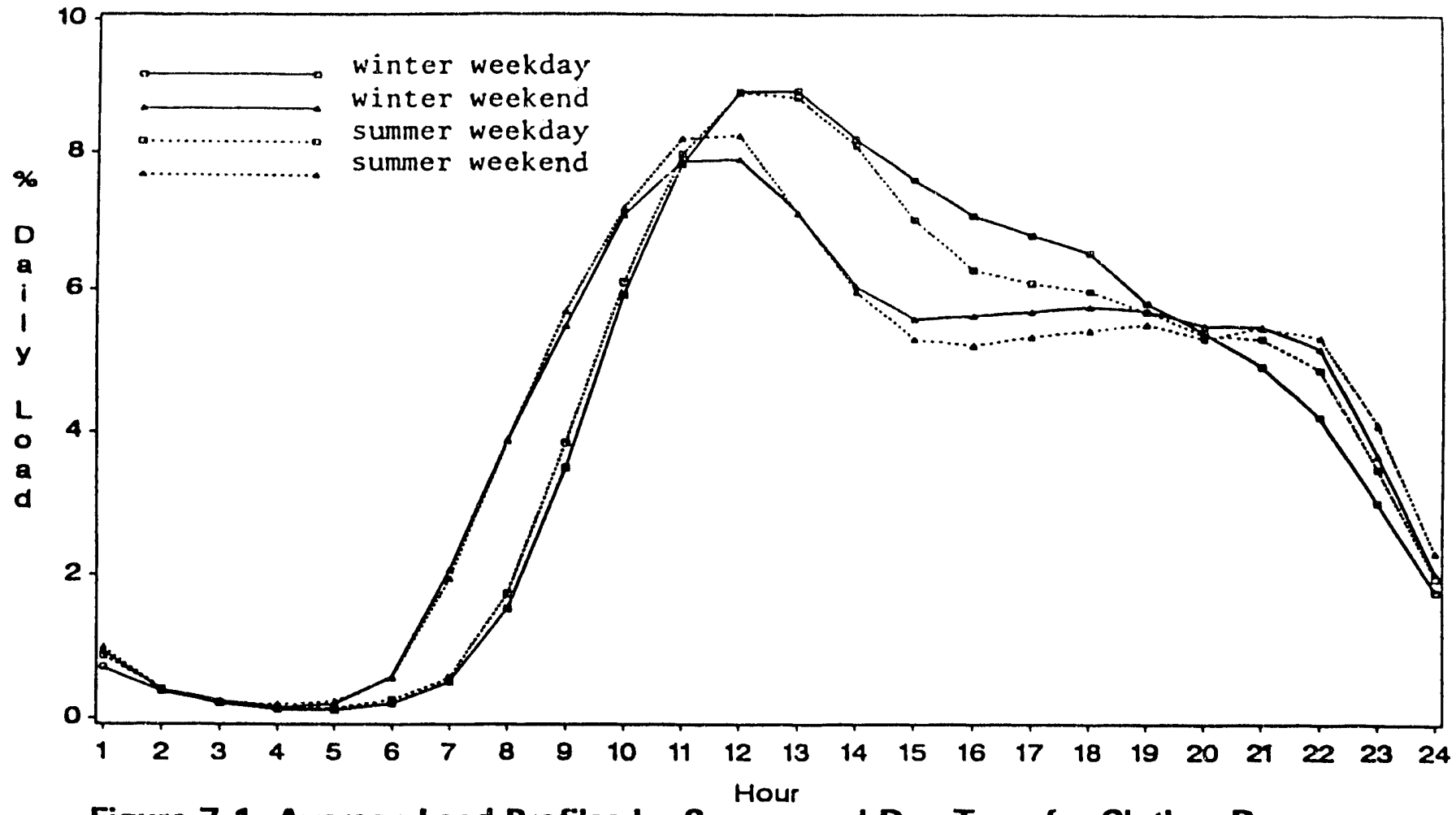

Figure 7-1 Average Load Profiles by Season and Day Type for Clothes Dryer

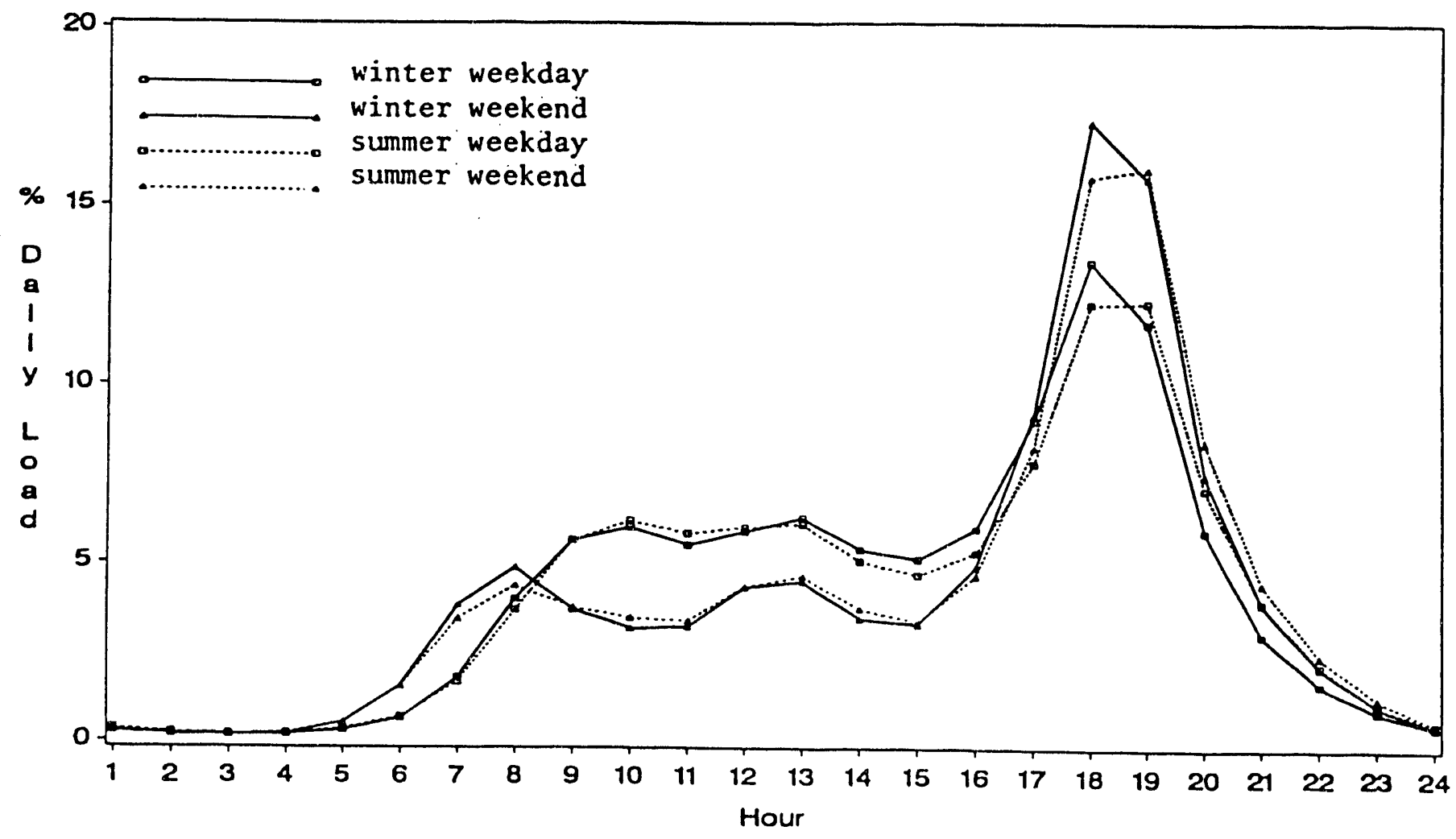

Figure 7-2 Average Load Profiles by Season and Day Type for Cooking 


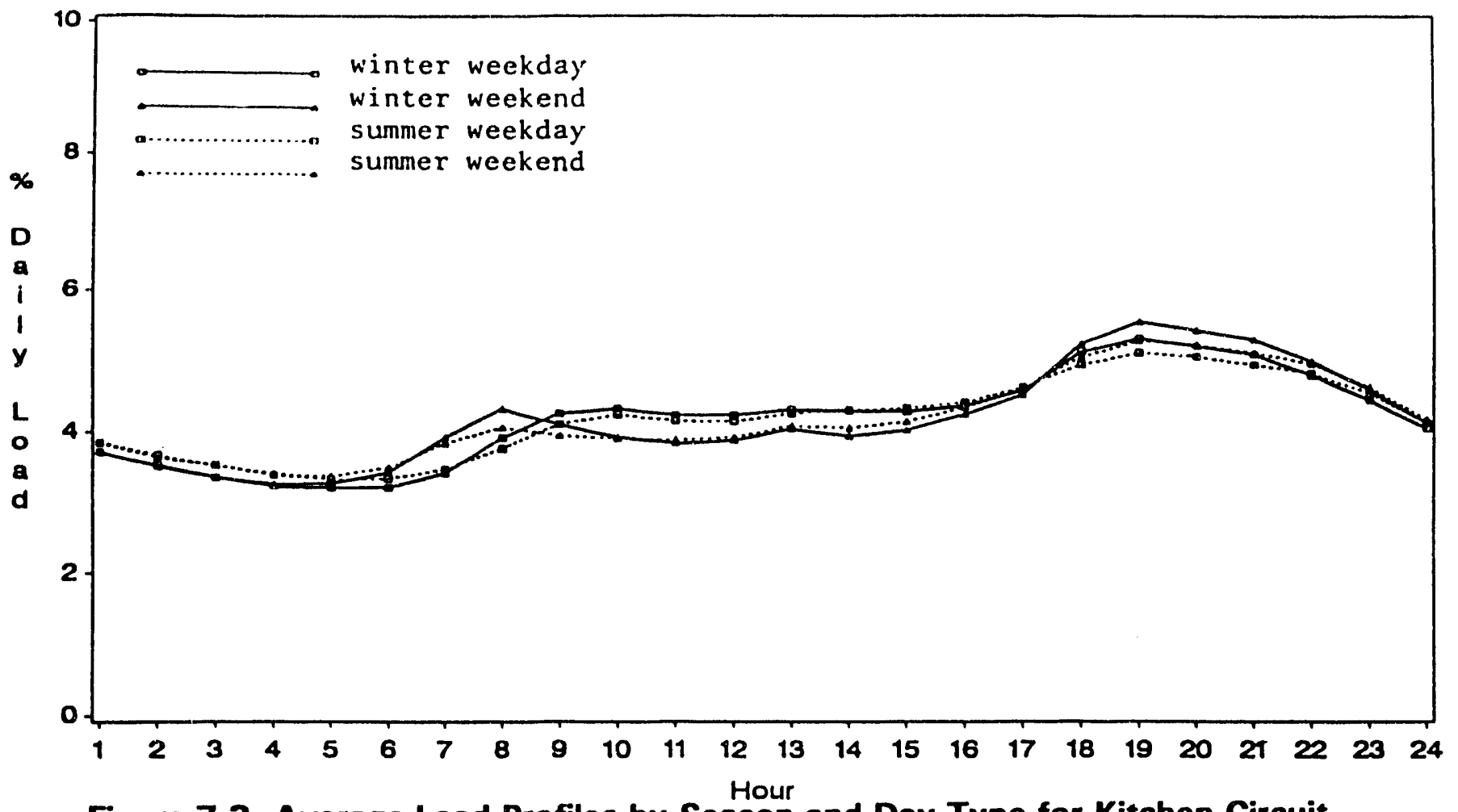

Figure 7-3 Average Load Profiles by Season and Day Type for Kitchen Circuit

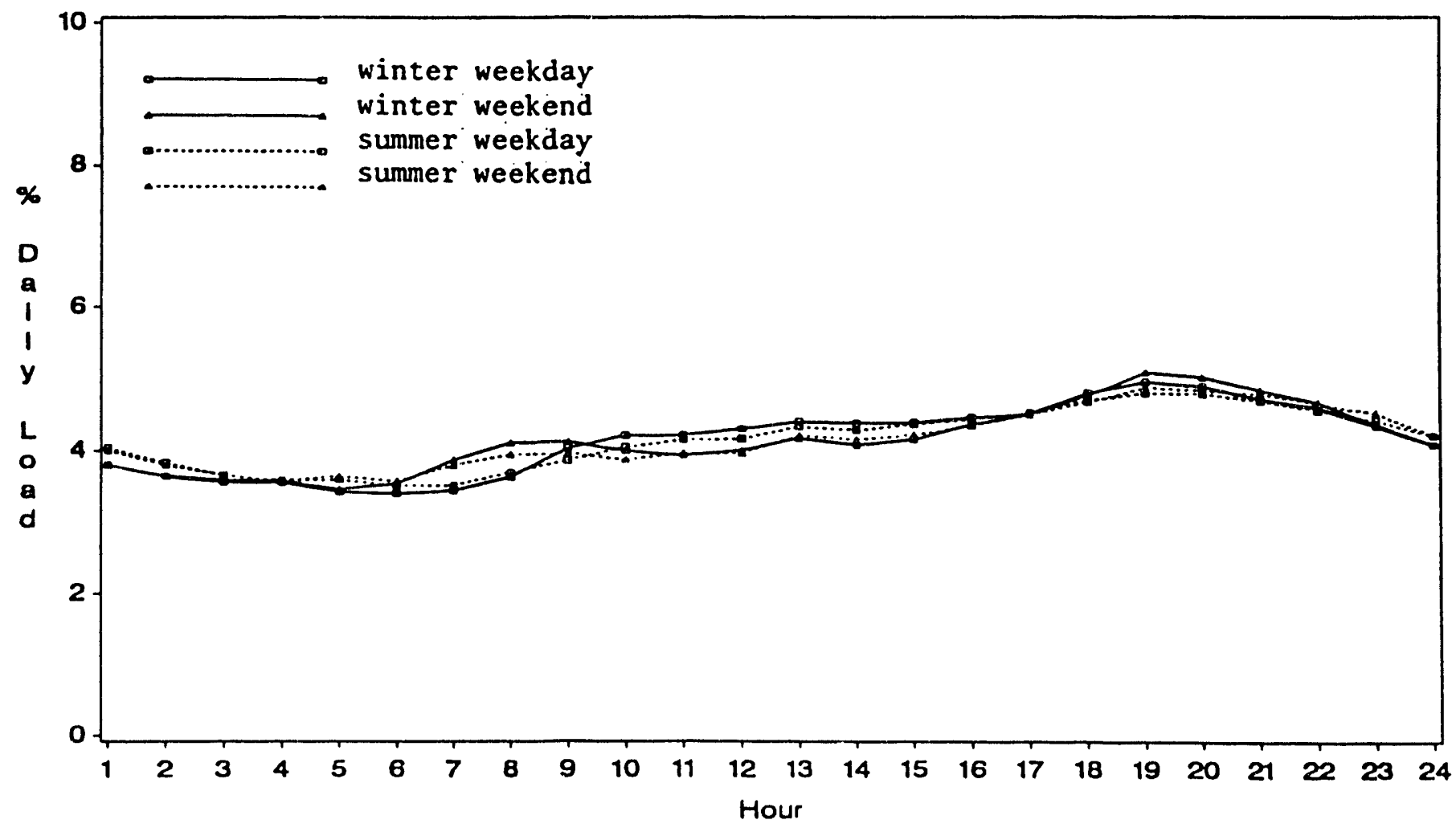

Figure 7-4 Average Load Profiles by Season and Day Type for Refrigerator 


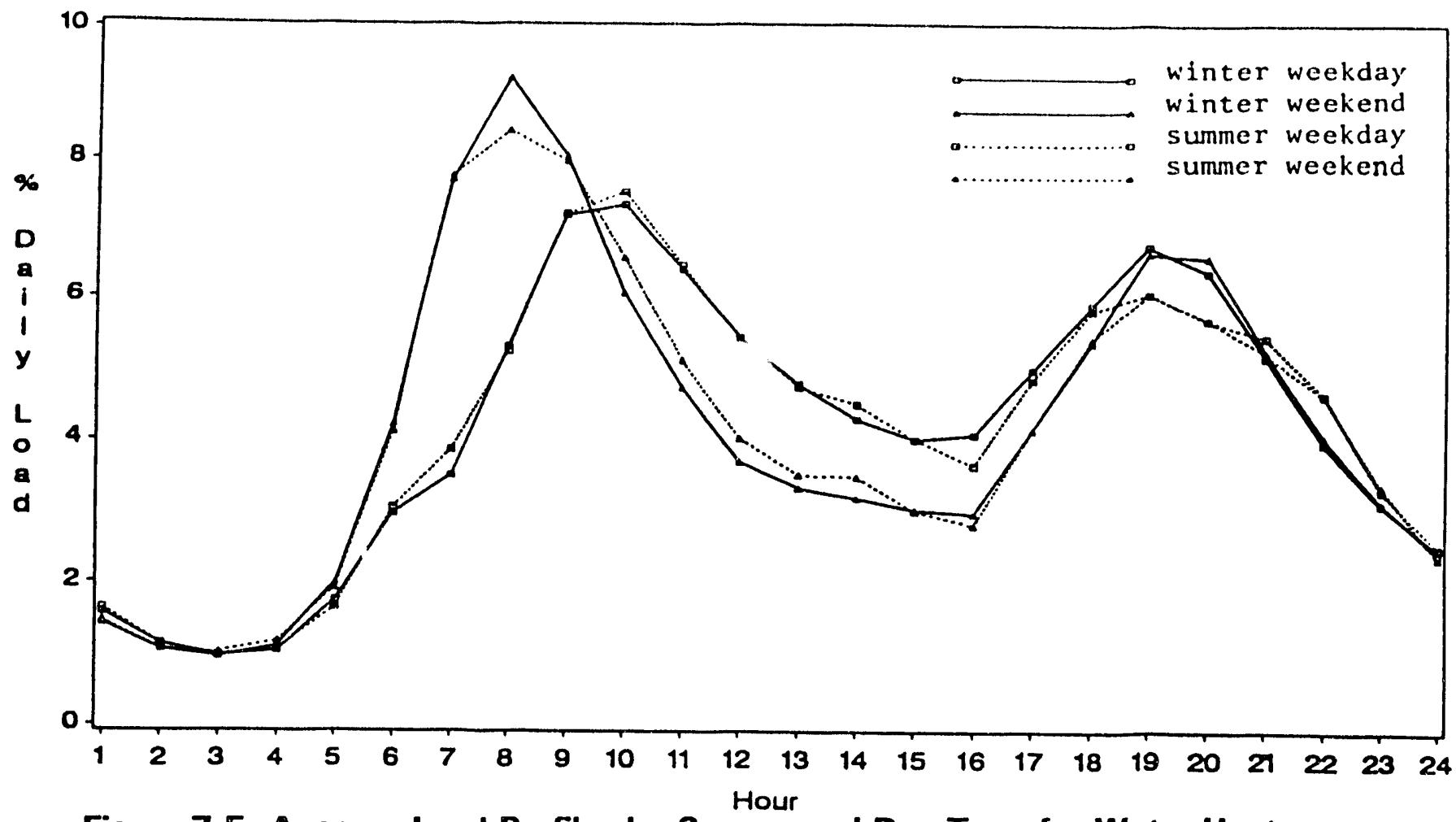

Figure 7-5 Average Load Profiles by Season and Day Type for Water Heater 


\section{References}

California Energy Commission (CEC) 1991, "California Energy Demand: 1991-2011, Volume II, Electricity Demand Forecasting Methods", CEC Publication P300-91-006, June.

Pacific Gas and Electric Company (PG\&E) 198\%, "Residential Appliance Load Study, 19851986", San Francisco CA, September.

ICF Resources Inc. 1991, "The Hourly Electric Load Model (HELM-PC), Personal Computer Version 1.0, User's Guide”, EPRI Research Project 2863-9, May.

Jaske, M.R. and S.W. Paige 1979, Technical Documentation of the Peak Load Forecasting Model, California Energy Commission, Sacramento CA.

McCullagh, P. and J.A. Nelder 1983, Generalized Linear Models, Chapman and Hall, New York, NY.

Ruderman, Henry, J. H. Eto, K. Heinemeier, A. Golan and D. J. Wood 1989, "Residential End-Use Load Shape Data Analysis”, LBL-27114, Universitywide Energy Research Group, April. 


\section{Appendix A Data Handling Conventions and Review}

Prior to our analysis, we developed a number of conventions for handling data. These included the assignment of individual households to the CEC and PG\&E geographic regions or zones used in our analysis, the aggregation of half-hourly loads to hours and the alignment of these loads with the weather data, and definition of day types and treatment of missing values when developing UECs. We describe development of these conventions in this appendix along with our exploratory review of the 1989 space conditioning data (mentioned in Chapter 4).

\section{Geographic Coding}

We used two distinct sets of geographic aggregations: a set of five climate regions used by CEC, and a set of four climate zones used by PG\&E. To avoid confusion we refer to these geographic aggregations as CEC Regions and PG\&E Zones, respectively. Figure A-1 is a map of CEC Regions. Figure A-2, A-3, A-4 and A-5 are maps of PG\&E Zones R, S, T and X respectively. Region and zone-specific analyses were conducted only for the two weather-sensitive end uses analyzed, central irir conditioning and room air conditioning. We used CEC Regions along with associated NOAA weather data to develop the time-temperature matrices for CEC's peak model, and PG\&E Zones with weather data from PG\&E weather stations to develop inputs for use in the PG\&E load shape model.

To make CEC Climate Region assignments for metered air conditioners, we used the zip code of the residence (which PG\&E provided to LBL in the file LBLID.DAT) and then selected a CEC Climate Region according to the zip code/climate region correspondence given to us by CEC in the file ZIPZONE.DAT. We reviewed these initial assignments by comparing the county of each zip code as given in ZIPZONE.DAT to the county as given by U.S. census and postal information to determine cases for which there was a discrepancy in county coding. Based on zip code location and our inspection of the CEC map of geographic climate zones, we proposed climate region reassignments for residences in 41 zip codes. We carried out these proposed reassignments for the analyses discussed in this report, with the concurrence of CEC. Details on these reassignments are discussed in our data review memorandum (June 1991).

Each rf:sidence was also assigned to one of four PG\&E climate Zones, R, S, T, or X with corresponding PG\&E weather stations Fresno, Sacramento, Salinas, and San Ramon. These assignments were made according to the LBLID-Zone assignments provided by PG\&E in the file CLIMZONE.LBL. Each of these four zones is associated with a PG\&E weather station: Fresno for Zone R, Sacramento for Zone S, San Ramon for Zone X, and Salinas for Zone T. Zone T is not used for cooling demand forecasts. Of the 775 LBLIDs, 183 were assigned to Zone $R$, 243 were assigned to Zone S, 267 were assigned to Zone $X$, and 82 were assigned to Zone T. 
The number of central and room air conditioners metered in each of these zones is given in Table 3-2.

\section{Weather Data}

We used two sets of weather data in this study, one set derived from NOAA weather data, and a second set of data from PG\&E weather stations. Each CEC Region is associated with a NOAA weather station. Each PG\&E Zone is associated with a PG\&E weather station. The weather stations were used to provide weather data for corresponding regions and zones for weather-sensitive analyses such as those for cooling. As described previously, PG\&E forecasts space conditioning loads separately for only three Zones (R,S, and X).

CEC provided LBL with a modified NOAA weather data set consisting of hourly wet- and drybulb temperature measurements for 1985-1989 at six weather stations: Blue Canyon, Fresno, San Jose, San Francisco, Sacramento, and Sunnyvale. Data missing from the original NOAA weather data sets had been filled in by CEC. According to NOAA documentation, hourly weather data are observed within ten minutes to the hour for which the data are reported. The Blue Canyon weather station is assigned to CEC Region 1, the Sacramento weather station is assigned to CEC Region, the Fresno weather station is assigned to CEC Region 3, the San Jose (1986-1989) and Sunnyvale (1985) weather stations are assigned to CEC Region 4, and the San Francisco Airport weather station is assigned to CEC Region 5.

No weather data were available for CEC Region 1 for 1985, so 1985 CEC Region 1 data were not used in constructing the time-temperature matrix.

Each of the PG\&E weather data sets contains half-hourly measurements of dry-bulb temperature and relative humidity for 25 weather stations for each of five years, 1985-1989. In this report we use data from only three of these stations, Fresno, Sacramento, and San Ramon. We considered daily average temperature missing if fewer than 24 of the 48 possible half-hourly temperatures were reported for that day.

For each station-hour of the NOAA data, we computed an index of climatic severity called the temperature-humidity index (THI). This index was used in developing the time-temperature matrices and in the allocation of annual to peak day energy use. The definition we used to compute THI is:

$$
T H I=0.4 *(\text { dry-bulb temperature }+ \text { wet-bulb temperature })+15,
$$

with dry-bulb and wet-bulb temperatures given in degrees Fahrenheit. The CEC model for air conditioning demand uses the THI degree-days, or THI-DD, to allocate annual demand to peak day demand. We computed THI-DD with a base temperature of 68 degrees: 


$$
\left.T H I-D D[\text { day } k]=\sum_{i=1}^{2 A} \max \{\text { THI [hour } i, \text { day } k]-68,0\right\}
$$

THI-DD serves as a measure of those hours that contribute to cooling loads (CEC defines these as hours with THI temperatures in excess of $68^{\circ}$ Fahrenheit).

\section{PG\&E End-Use Load Data}

Load data for 1985 and 1986 were obtained from PG\&E in 1989 as SAS data sets AMPLBL1 and AMPLBL2. These data sets contained half-hourly loads for both conditioning and nonconditioning appliances and for total household. Cooling load data for 1987, 1988, and 1989 were received from PG\&E in the SAS data sets CECRES87, CECRES88, and LBLRES89. Load data for heating and non-conditioning appliances for 1989 were received from PG\&E in the SAS data set LBLNONAC. Data for 1987, 1988, and 1989 were reported on an hourly basis. Each data set contained data for total household load in addition to loads for specific appliances.

PG\&E reports load data at the end of the measurement interval. For example, in the 1987, 1988 , and 1989 hourly data provided by PG\&E, the $1 \mathrm{a} . \mathrm{m}$. hourly load is the load between 12 midnight and 1 a.m.. We used this convention to compute hourly average loads from the 1985 and 1986 half-hourly load data. For consistency with PG\&E's reporting procedure, we defined the hourly load for a given hour as the average of the loads reported for the two preceding halfhours. For example, load demand for 1 a.m. was computed as the average of the 12:30 a.m. and $1 \mathrm{a} . \mathrm{m}$. loads. If data for only one of the two half-hours was available, we estimated the corresponding hourly demand using only the demand for the half-hour.

As noted in Chapter 3, we combined the data for four appliance codes, range top only, range and oven, oven only and range and oven and microwave, into a single end use which we refer to as cooking.

\section{Time Conventions}

The NOAA weather data are always reported in Local Standard Time whereas the PG\&E weather and load data are recorded using Daylight Savings Time. In creating the THI-hourly load matrix, we converted the NOAA data to Daylight Savings Time for consistency.

For this report Weekend is defined as Saturday, Sunday, or one of the eight holidays listed on the PG\&E rate schedule: New Year's Day, President's Day, Memorial Day, Independence Day, Labor Day, Veteran's Day, Thanksgiving Day, and Christmas Day. A Weekday is any other day. 


\section{Calculation of UECs}

To calculate the UECs reported in Chapter 3, we developed several conventions for treating incomplete records. The load data provided by PG\&E had few "missing" values (denoted in SAS by "."). Instead, it appears that PG\&E's policy was to delete entire daily records when missing or suspicious values were encountered in the raw metered data.

A residence's monthly UEC was considered missing if load data for more than seven days of that month were missing, excluded from the monthly mean. Otherwise, missing days were replaced with the mean daily energy use from the non-missing days of data.

Mean annual UEC is defined as the sum of monthly mean UECs. Standard deviation of the annual UEC is the square root of the sum of monthly variance of UEC over the 12 months of the year. (Variance is the square of standard deviation.) The basis of the computation is the mathematical fact that the variance of the sum of independent random variables is equal to the sum of the variance of the independent variables. Although the monthly UECs for a particular residence are probably not quite independent, we assume them to be independent for this computation. Direct computation of standard deviation of annual UEC is somewhat impractical due to incompleteness of the annual record for many residences.) Mean all-years UEC is the average of annual UEC taken without regard to year, and thus may differ slightly from an average of annuar mean UECs because of small variations in the number of households contributing to annual mean from year to year.

As noted in Chapter 3, late into the project we received PG\&E's recently developed household air conditioner weights in data sets DELNEW87, DELNEW88, and DELNEW89. These data sets contained summer (May - October) weights for central air conditioner, heat pump compressor, and total household load; and winter (November - April) weights for heat pump compressor and total household load. The 1989 analysis weight file also included weights for room air conditioner, clothes dryer, heat pump compressor, refrigerator, range and range with oven, oven, and water heater.

\section{Data Review}

The load data provided by PG\&E had already been subjected to extensive review by the PG\&E load research group. In general, we relied on their efforts and used the data without extensive additional review (beyond treatment of missing data).

As noted in Chapter 4, we subjected the 1989 space conditioning data to an extensive internal review in order to gain familiarity with the data set. The review included: completeness of records (number of missing days of load data); examination of outliers (we assumed outliers were data that did not fall within the following ranges: total household $0-20 \mathrm{~kW}$; central A/C $0-10 \mathrm{~kW}$; room A/C 0-5 kW); internal consistency of household and $A / C$ loads ( $A / C$ load must 
be less than or equal to total household load; examination of households reporting no load; and finally, visual review of 3-D graphs of the load data to identify unusual load patterns.

The findings from this review were summarized in a memo (dated June 18, 1991) and reviewed with PG\&E and CEC. The review provided additional insight into some of the metering issues underlying the load data (e.g., central AC often includes ventilation fans, whose loads can be detected in Winter) and an opportunity to determine how best to treat the data in our analyses. For example, based on the meeting, we decided not to include data from two households whose data were anomalous, and eliminated a duplicate, but apparently distinct, record from a single household. 


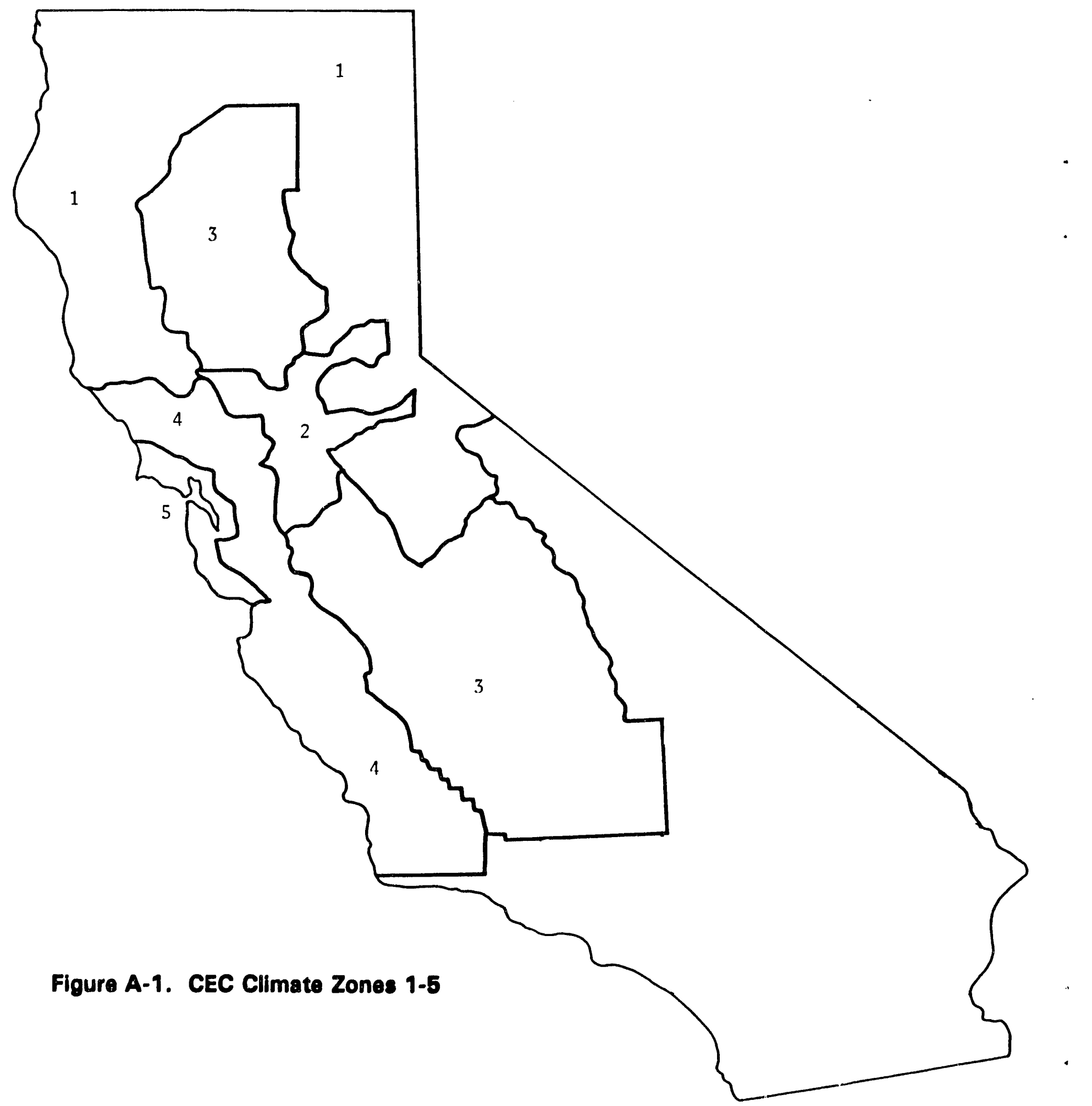

XBL 874-8839 


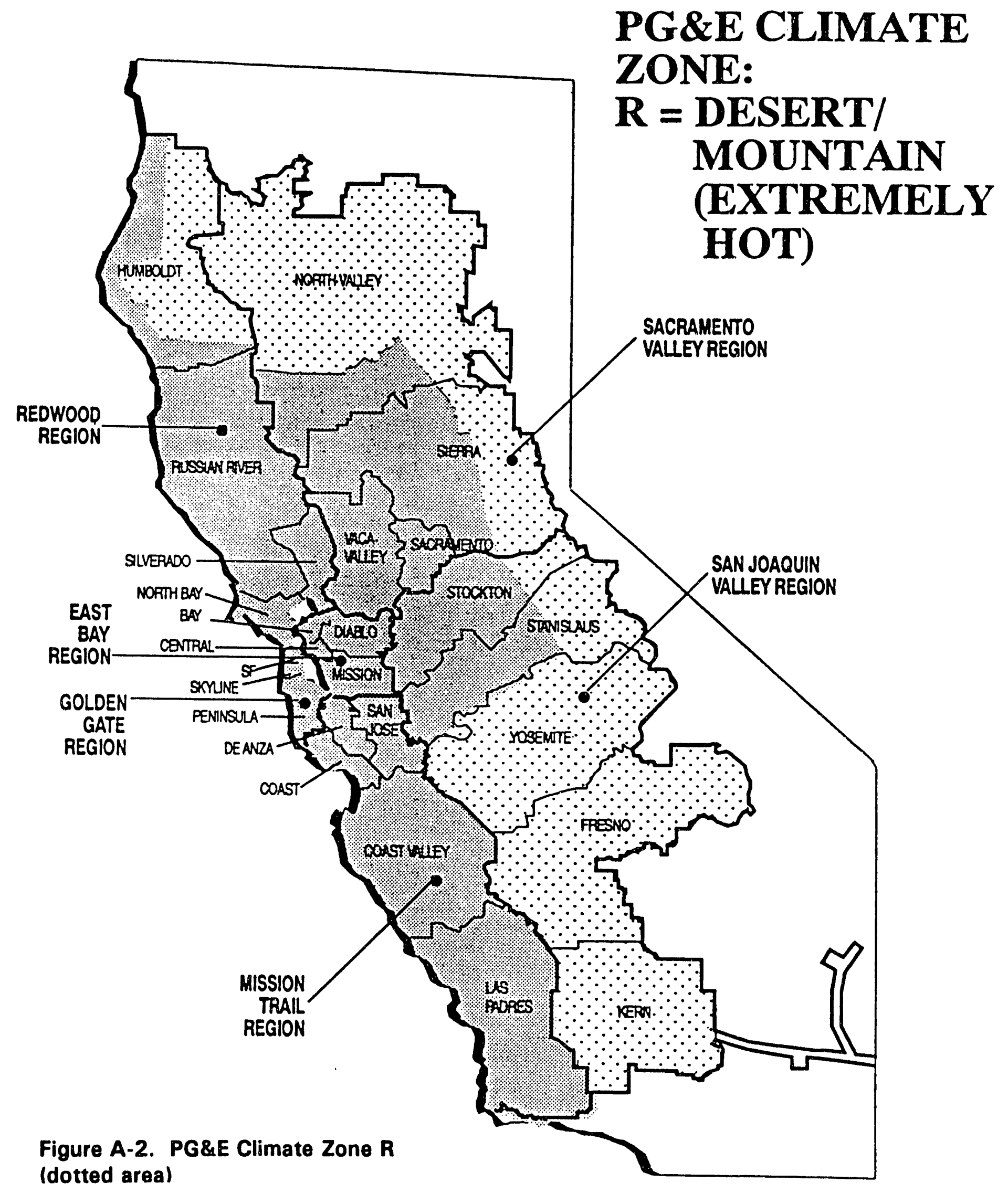




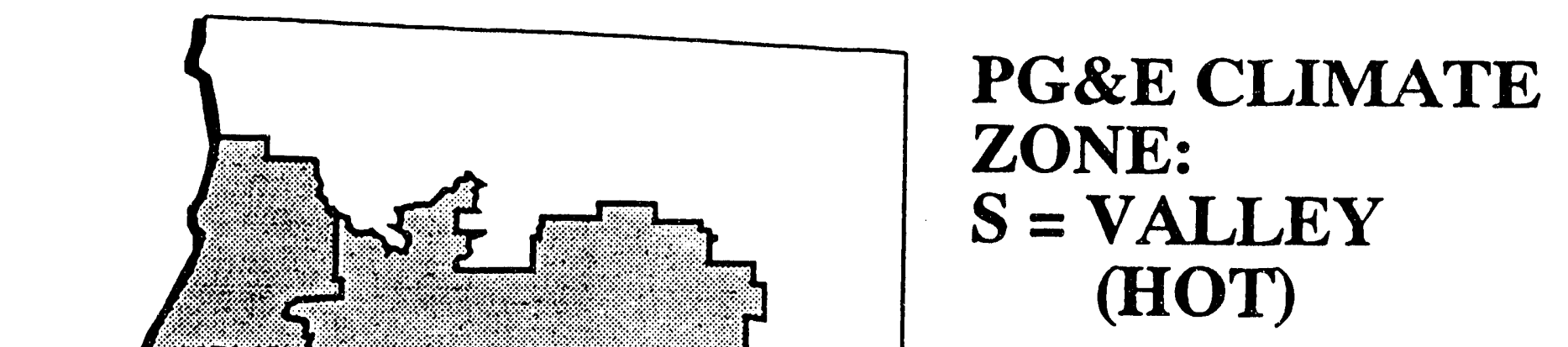

REDWOOD

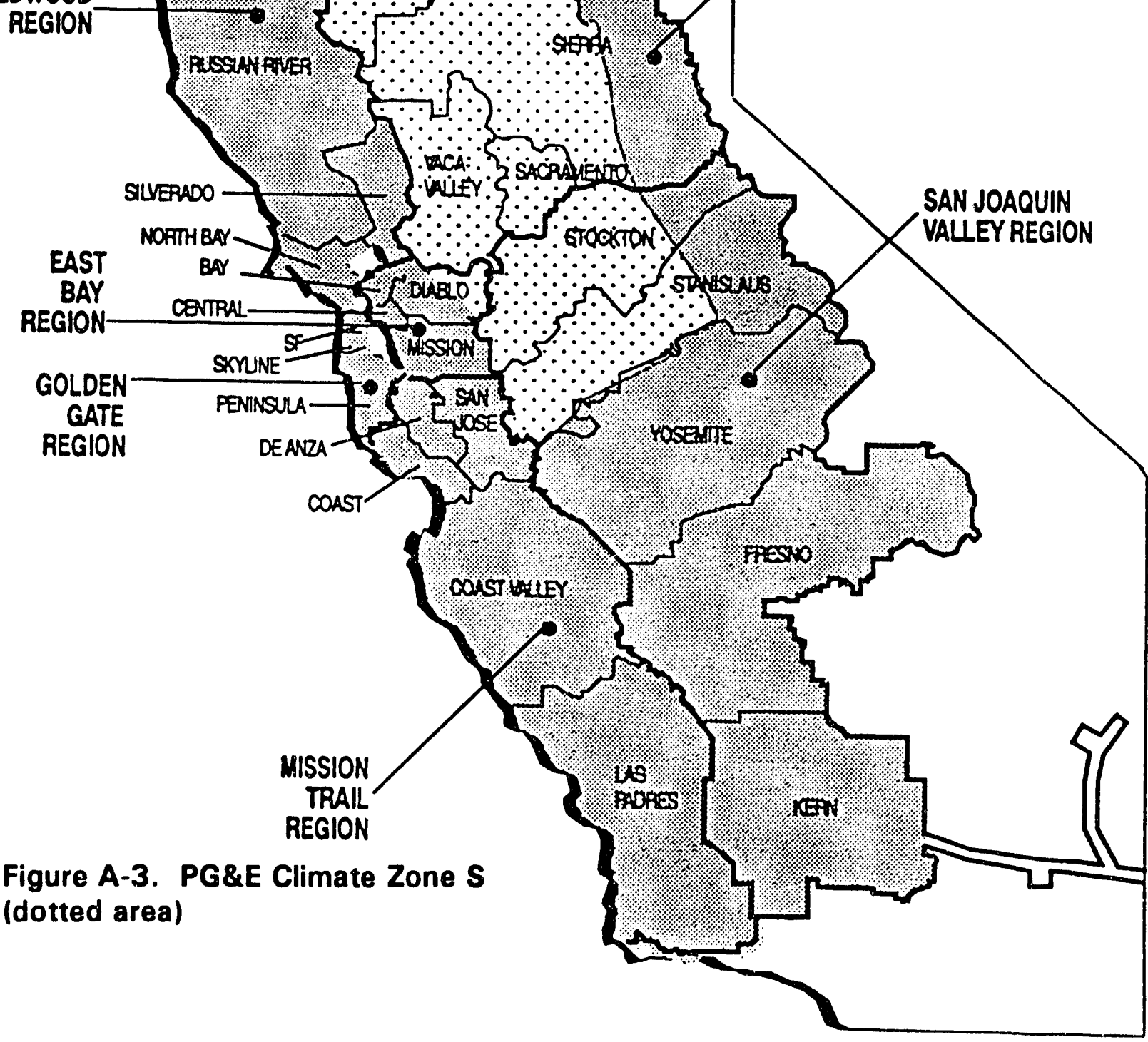




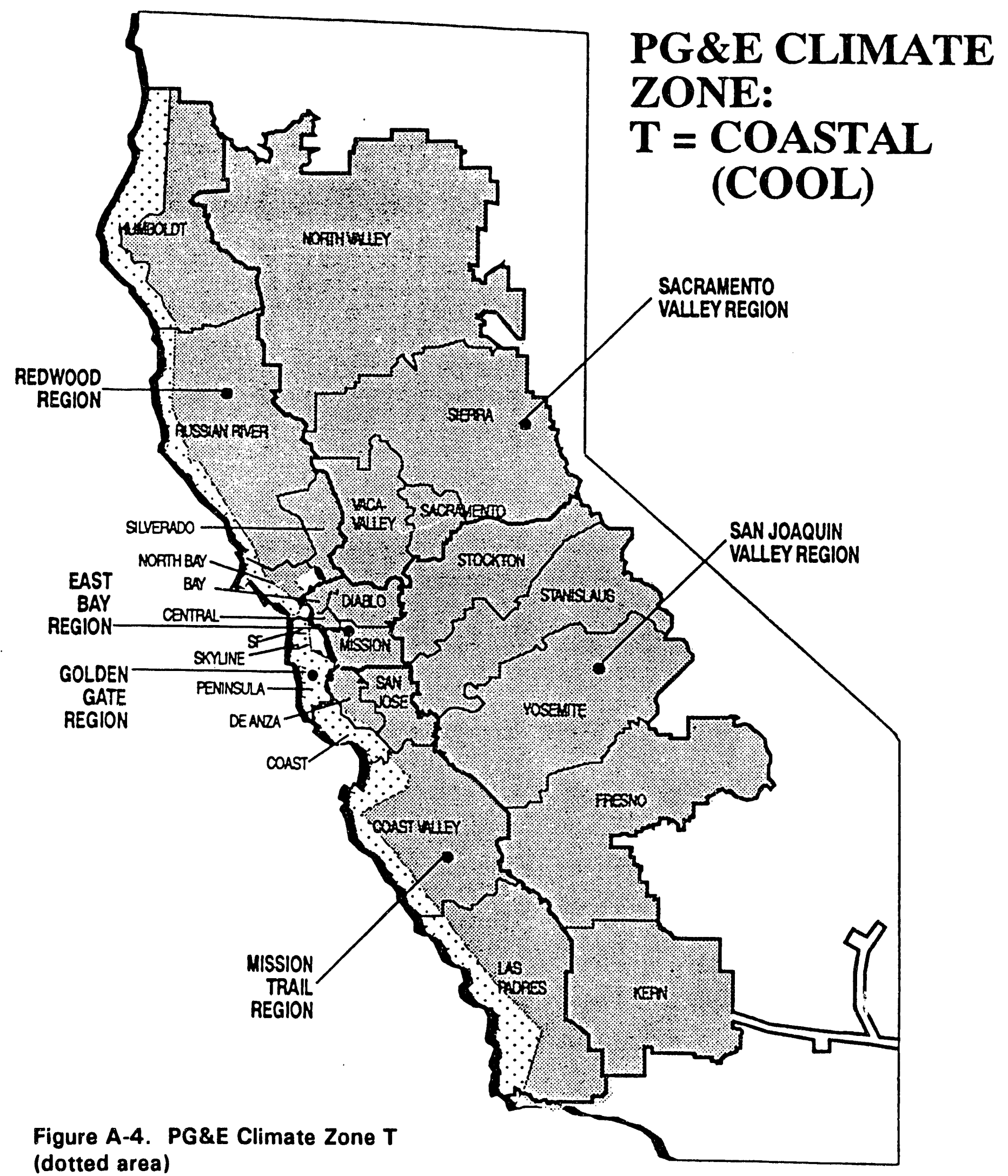




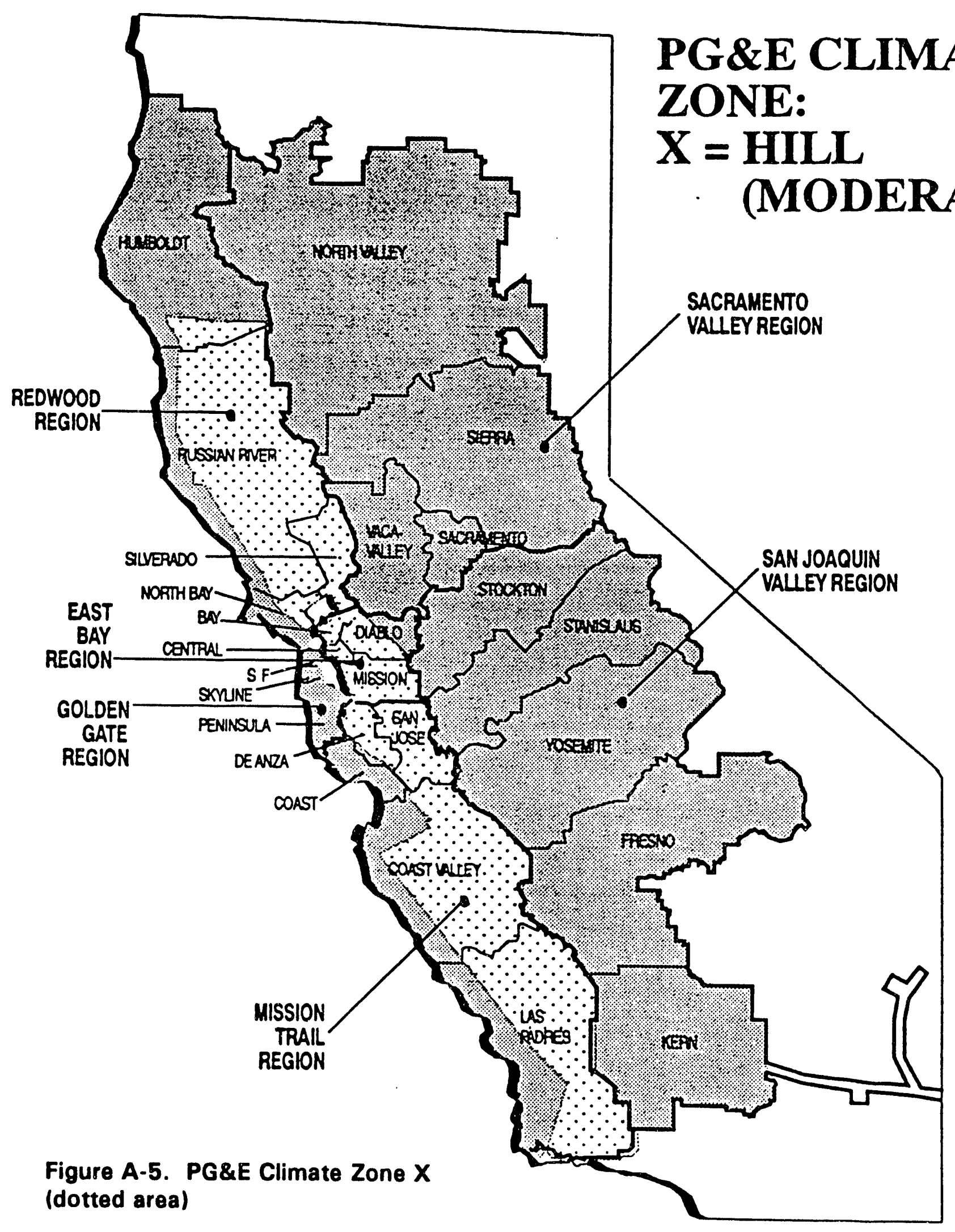




\section{Appendix B \\ Data Tables for Chapter 3}


Mean, Standard Deviation, and $\mathrm{N}$ for Monthly UEC

$$
\text { Central Air conditioner Region } 2
$$

$\begin{array}{lrrrrrr}\text { MONTH } & \text { UEC85 } & \text { UEC86 } & \text { UEC87 } & \text { UEC88 } & \text { UEC89 } & \text { UECALI } \\ \text { Jan } & 43 & 30 & 51 & 28 & 34 & 37 \\ \text { Feb } & 28 & 28 & 36 & 20 & 29 & 28 \\ \text { Mar } & 24 & 24 & 32 & 18 & 23 & 25 \\ \text { Apr } & 20 & 19 & 28 & 20 & 35 & 24 \\ \text { May } & 24 & 69 & 151 & 54 & 52 & 72 \\ \text { Jun } & 312 & 166 & 189 & 231 & 140 & 211 \\ \text { JuI } & 384 & 308 & 181 & 527 & -337 & 337 \\ \text { Aug } & 141 & 306 & 280 & 251 & 199 & 235 \\ \text { Sep } & 50 & 81 & 137 & 155 & 78 & 101 \\ \text { Oct } & 39 & 16 & 61 & 22 & 16 & 32 \\ \text { Nov } & 39 & 21 & 22 & 27 & 16 & 25 \\ \text { Dec } & 45 & 31 & 82 & 48 & 29 & 46\end{array}$

Central Air Conditioner Region 2

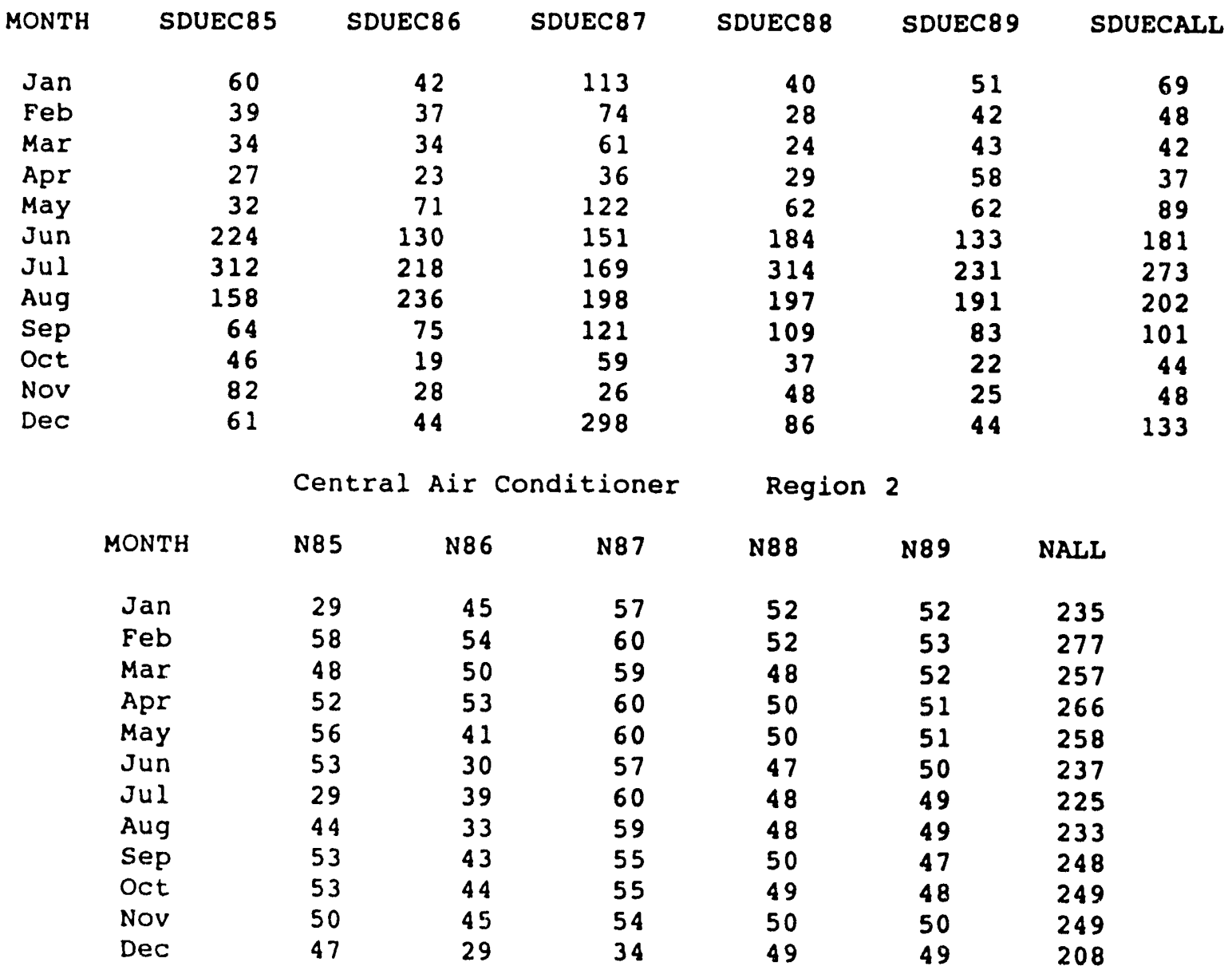




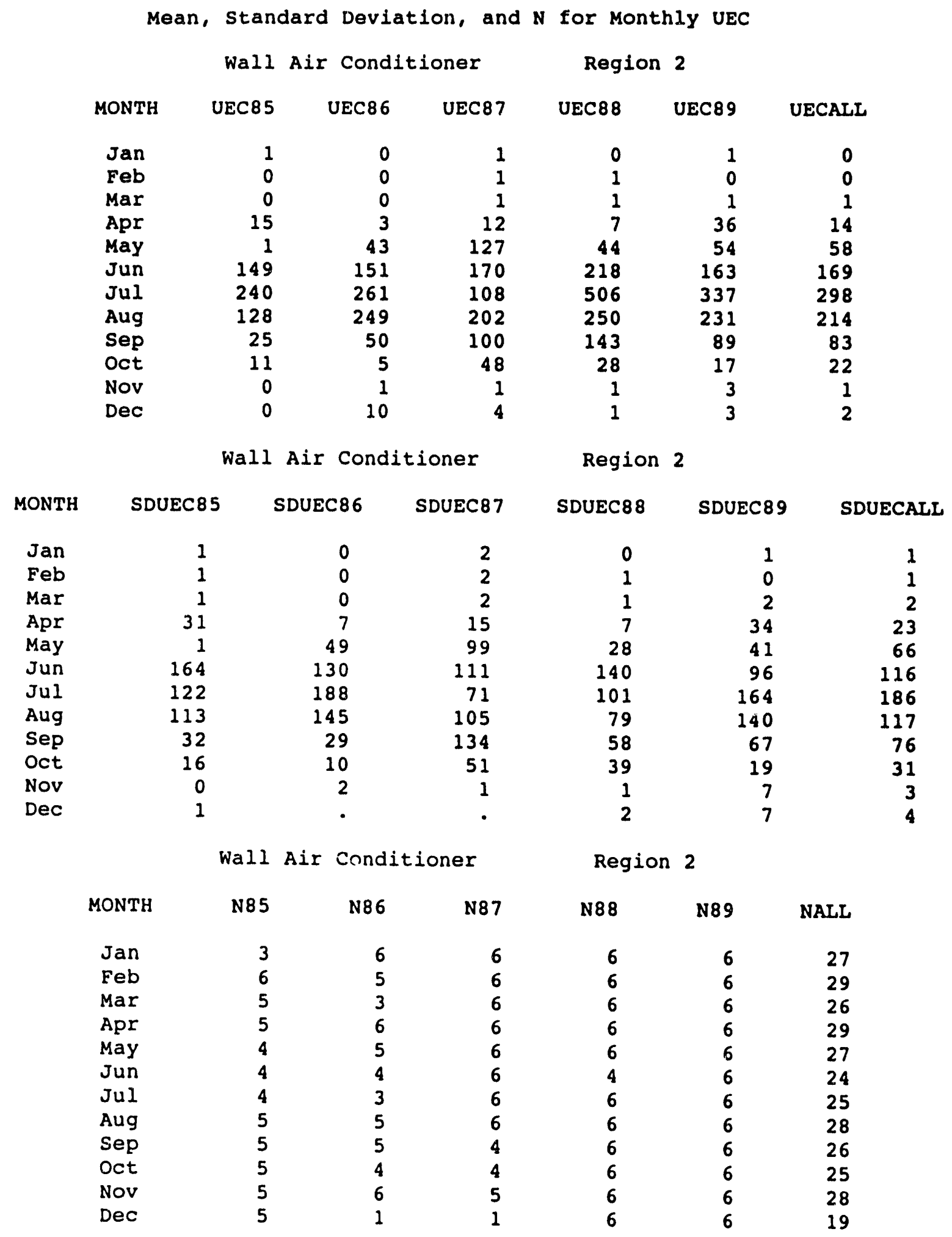


Mean, Standard Deviation, and $\mathbf{N}$ for Monthly UEC

Central Air conditioner Region 3

$\begin{array}{lrrrrrr}\text { MONTH } & \text { UEC85 } & \text { UEC86 } & \text { UEC87 } & \text { UEC88 } & \text { UEC89 } & \text { UECALL } \\ \text { Jan } & 46 & 31 & 79 & 43 & 48 & 51 \\ \text { Feb } & 30 & 24 & 58 & 29 & 35 & 36 \\ \text { Mar } & 26 & 21 & 53 & 21 & 21 & 29 \\ \text { Apr } & 20 & 17 & 33 & 17 & 29 & 24 \\ \text { May } & 33 & 87 & 168 & 57 & 52 & 82 \\ \text { Jun } & 440 & 250 & 323 & 267 & 205 & 299 \\ \text { Jul } & 612 & 396 & 274 & 777 & 475 & 492 \\ \text { Aug } & 244 & 468 & 433 & 414 & 316 & 378 \\ \text { Sep } & 49 & 128 & 158 & 245 & 117 & 142 \\ \text { Oct } & 29 & 18 & 71 & 34 & 14 & 34 \\ \text { Nov } & 27 & 19 & 47 & 28 & 23 & 30 \\ \text { Dec } & 49 & 40 & 119 & 50 & 42 & 54\end{array}$

Central Air Conditioner Region 3

$\begin{array}{lrrrrrr}\text { MONTH } & \text { SDUEC85 } & \text { SDUEC86 } & \text { SDUEC87 } & \text { SDUEC88 } & \text { SDUEC89 } & \text { SDUECALL } \\ \text { Jan } & 48 & 32 & 156 & 64 & 66 & 91 \\ \text { Feb } & 34 & 25 & 12 \% & 45 & 54 & 71 \\ \text { Mar } & 26 & 25 & 127 & 36 & 38 & 68 \\ \text { Apr } & 33 & 25 & 50 & 28 & 45 & 39 \\ \text { May } & 60 & 80 & 145 & 61 & 63 & 103 \\ \text { Jun } & 289 & 191 & 309 & 204 & 203 & 261 \\ \text { Jul } & 388 & 292 & 218 & -1 & 350 & 393 \\ \text { Aug } & 228 & 366 & 310 & -16 & 274 & 309 \\ \text { Sep } & 63 & 93 & 150 & 192 & 134 & 152 \\ \text { Oct } & 33 & 30 & 77 & 70 & 25 & 56 \\ \text { Nov } & 27 & 21 & 95 & 42 & 37 & 56 \\ \text { Dec } & 62 & 42 & 319 & 70 & 60 & 121\end{array}$

Central Air Conditioner Region 3

$\begin{array}{lrrrrrr}\text { MONTH } & \text { N85 } & \text { N86 } & \text { N87 } & \text { N88 } & \text { N89 } & \text { NALL } \\ \text { Jan } & 111 & 120 & 162 & 143 & 142 & 678 \\ \text { Feb } & 143 & 138 & 164 & 145 & 147 & 737 \\ \text { Mar } & 119 & 126 & 158 & 134 & 143 & 680 \\ \text { Apr } & 126 & 128 & 162 & 138 & 144 & 698 \\ \text { May } & 137 & 114 & 161 & 138 & 141 & 691 \\ \text { Jun } & 126 & 101 & 159 & 134 & 131 & 651 \\ \text { Jul } & 64 & 112 & 162 & 143 & 141 & 622 \\ \text { Aug } & 92 & 82 & 158 & 140 & 143 & 615 \\ \text { Sep } & 130 & 99 & 137 & 142 & 143 & 651 \\ \text { Oct } & 130 & 108 & 136 & 140 & 135 & 649 \\ \text { Nov } & 123 & 103 & 156 & 121 & 138 & 641 \\ \text { Dec } & 117 & 56 & 54 & 134 & 139 & 500\end{array}$




\begin{tabular}{|c|c|c|c|c|c|c|}
\hline \multirow[b]{2}{*}{ MONTH } & \multirow{2}{*}{$\begin{array}{r}\text { Wall } \\
\text { UEC8 } 5\end{array}$} & \multicolumn{2}{|c|}{ Air Conditioner } & \multicolumn{2}{|c|}{ Region 3} & \multirow[b]{2}{*}{ UECALI } \\
\hline & & UEC86 & UEC87 & UEC 88 & UEC8 9 & \\
\hline Jan & 15 & 2 & 5 & 16 & 0 & 8 \\
\hline Feb & 0 & 5 & 0 & 4 & 0 & 2 \\
\hline Mar & 2 & 0 & 2 & 1 & 0 & 1 \\
\hline Apr & 6 & 0 & 2 & $\mathbf{0}$ & 0 & 2 \\
\hline May & 5 & 36 & 53 & 12 & 6 & 23 \\
\hline Jun & 129 & 79 & 139 & 120 & 50 & 103 \\
\hline Jul & 129 & 180 & 100 & 348 & 178 & 186 \\
\hline Aug & 60 & 182 & 174 & 124 & 94 & 129 \\
\hline Sep & 7 & 67 & 66 & 126 & 14 & 50 \\
\hline Oct & 1 & 6 & 26 & 1 & 1 & 5 \\
\hline Nov & 2 & 6 & 12 & 1 & 0 & 4 \\
\hline Dec & 14 & 31 & 0 & 1 & 0 & 8 \\
\hline
\end{tabular}

Wall Air Conditioner

Region 3

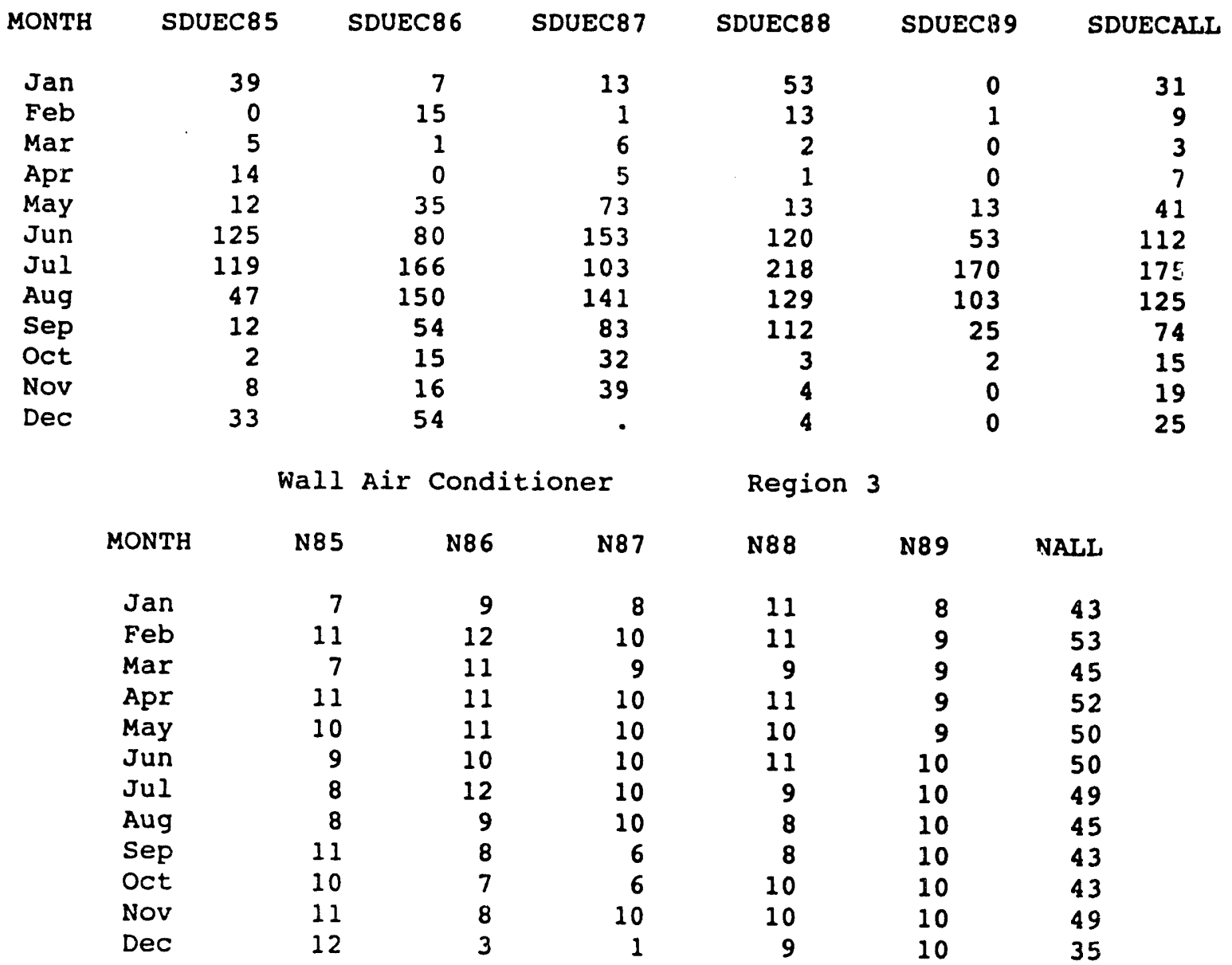


Mean, Standard Deviation, and $\mathrm{N}$ for Monthly UEC

Central Air Conditioner Region 4

$\begin{array}{lrrrrrr}\text { MONTH } & \text { UEC85 } & \text { UEC86 } & \text { UEC87 } & \text { UEC88 } & \text { UEC89 } & \text { UECALI } \\ \text { Jan } & 36 & 27 & 30 & 20 & 23 & 27 \\ \text { Feb } & 21 & 21 & 22 & 15 & 18 & 19 \\ \text { Mar } & 26 & 18 & 23 & 15 & 12 & 19 \\ \text { Apr } & 32 & 23 & 28 & 21 & 46 & 30 \\ \text { May } & 30 & 47 & 137 & 55 & 42 & 63 \\ \text { Jun } & 229 & 111 & 113 & 139 & 110 & 140 \\ \text { Jul } & 332 & 188 & 96 & 401 & 227 & 235 \\ \text { Aug } & 93 & 149 & 165 & 185 & 111 & 141 \\ \text { Sep } & 37 & 53 & 97 & 123 & 46 & 71 \\ \text { Oct } & 41 & 27 & 128 & 33 & 17 & 49 \\ \text { Nov } & 30 & 20 & 25 & 20 & 14 & 22 \\ \text { Dec } & 38 & 41 & 71 & 23 & 22 & 32\end{array}$

Central Air conditioner Region 4

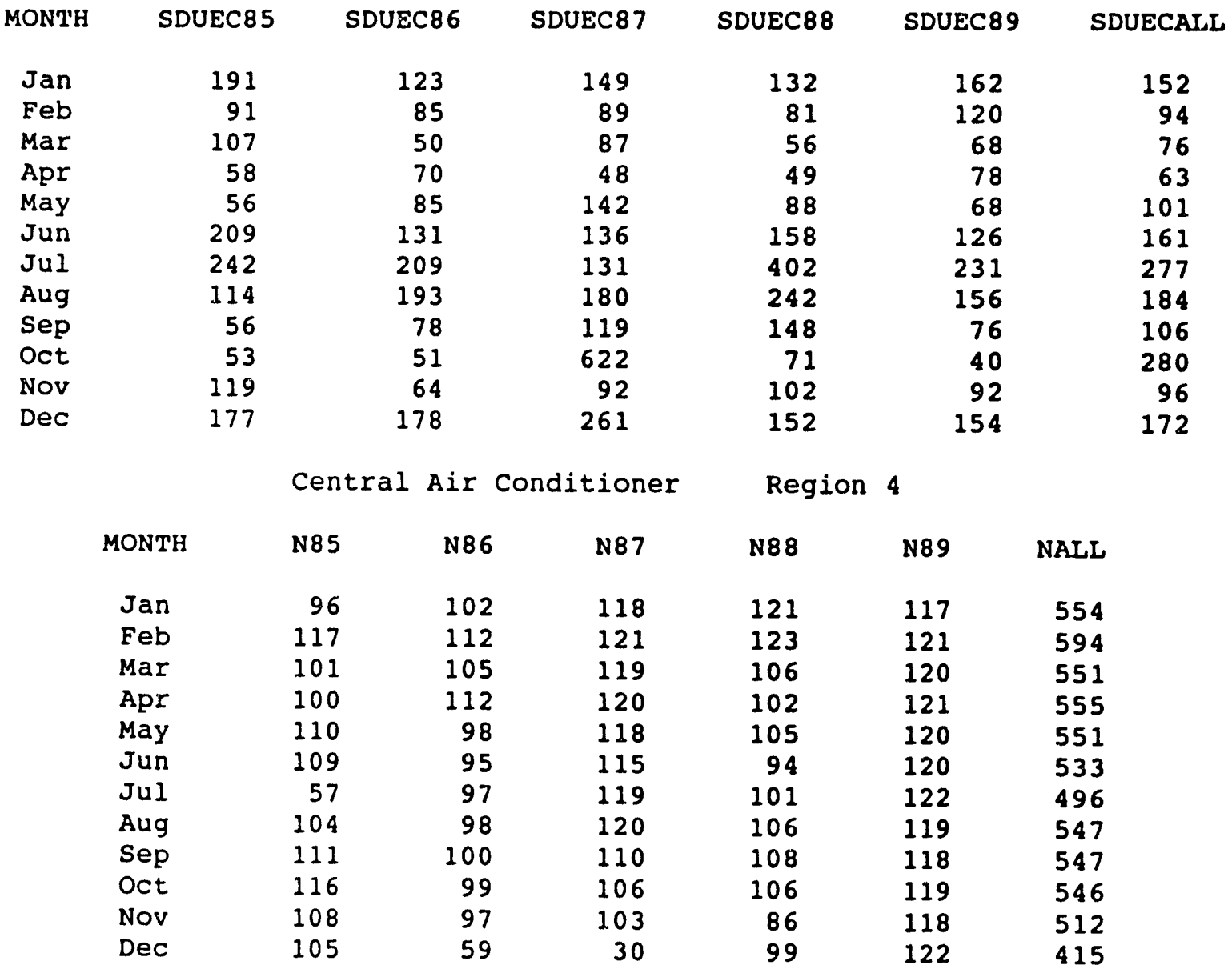


Mean, Standard Deviation, and $\mathrm{N}$ for Monthly UEC

Wall Air Conditioner Region 4

$\begin{array}{lrrrrrr}\text { MONTH } & \text { UEC85 } & \text { UEC86 } & \text { UEC87 } & \text { UEC88 } & \text { UEC89 } & \text { UECALL } \\ \text { ALL } & 296 & 226 & 433 & 502 & 393 & 376 \\ \text { Jan } & 7 & 6 & 8 & 10 & 11 & 8 \\ \text { Feb } & 4 & 2 & 5 & 11 & 11 & 7 \\ \text { Mar } & 4 & 2 & 7 & 9 & 13 & 7 \\ \text { Apr } & 13 & 2 & 12 & 14 & 32 & 14 \\ \text { May } & 7 & 11 & 137 & 29 & 24 & 47 \\ \text { Jun } & 87 & 54 & 59 & 66 & 59 & 65 \\ \text { Jul } & 103 & 71 & 38 & 168 & 109 & 93 \\ \text { Aug } & 33 & 45 & 77 & 91 & 65 & 64 \\ \text { Sep } & 15 & 16 & 41 & 58 & 36 & 34 \\ \text { Oct } & 12 & 8 & 25 & 15 & 12 & 15 \\ \text { Nov } & 5 & 4 & 8 & 14 & 9 & 8 \\ \text { Dec } & 4 & 5 & 15 & 18 & 12 & 11\end{array}$

Wall Air Conditioner Region 4

$\begin{array}{lrrrrrr}\text { MONTH } & \text { SDUEC85 } & \text { SDUEC86 } & \text { SDUEC87 } & \text { SDUEC88 } & \text { SDUEC89 } & \text { SDUECALI } \\ \text { Jan } & 19 & 16 & 18 & 25 & 28 & 21 \\ \text { Feb } & 10 & 5 & 13 & 33 & 27 & 21 \\ \text { Mar } & 14 & 6 & 18 & 22 & 33 & 21 \\ \text { Apr } & 21 & 6 & 21 & 24 & 34 & 25 \\ \text { May } & 12 & 18 & 452 & 32 & 30 & 228 \\ \text { Jun } & 71 & 62 & 80 & 46 & 46 & 64 \\ \text { Jul } & 92 & 78 & 47 & 124 & 92 & 98 \\ \text { Aug } & 48 & 50 & 72 & 76 & 65 & 67 \\ \text { Sep } & 23 & 25 & 50 & 49 & 39 & 42 \\ \text { Oct } & 16 & 13 & 31 & 23 & 24 & 23 \\ \text { Nov } & 15 & 15 & 21 & 33 & 21 & 21 \\ \text { Dec } & 10 & 18 & 34 & 42 & 28 & 29\end{array}$

Wall Air Conditioner Region 4

$\begin{array}{lrrrrrr}\text { MONTH } & \text { N85 } & \text { N86 } & \text { N87 } & \text { N88 } & \text { N89 } & \text { NALL } \\ \text { Jan } & 23 & 28 & 36 & 36 & 29 & 152 \\ \text { Feb } & 28 & 29 & 36 & 36 & 30 & 159 \\ \text { Mar } & 25 & 28 & 35 & 29 & 29 & 146 \\ \text { Apr } & 26 & 31 & 35 & 32 & 30 & 154 \\ \text { Mar } & 26 & 24 & 35 & 29 & 29 & 143 \\ \text { Jun } & 29 & 21 & 36 & 25 & 29 & 140 \\ \text { Jul } & 13 & 27 & 36 & 27 & 30 & 133 \\ \text { Aug } & 25 & 26 & 35 & 31 & 28 & 145 \\ \text { Sep } & 29 & 26 & 32 & 31 & 28 & 146 \\ \text { Oct } & 28 & 23 & 32 & 28 & 26 & 137 \\ \text { Nov } & 26 & 28 & 30 & 19 & 25 & 128 \\ \text { Dec } & 24 & 17 & 16 & 28 & 29 & 114\end{array}$


Mean, Standard Deviation, and $\mathrm{N}$ for Monthly UEC

Central Air Conditioner All Regions

$\begin{array}{lllllll}\text { MONTH UEC85 UEC86 UEC87 } & \text { UEC88 } & \text { UEC89 } & \text { UECALL }\end{array}$

$\begin{array}{lrrrrrr}\text { Jan } & 43 & 29 & 57 & 33 & 38 & 40 \\ \text { Feb } & 27 & 23 & 41 & 23 & 28 & 29 \\ \text { Mar } & 27 & 20 & 38 & 18 & 18 & 25 \\ \text { Apr } & 24 & 20 & 31 & 19 & 37 & 26 \\ \text { May } & 30 & 70 & 153 & 57 & 50 & 74 \\ \text { Jun } & 336 & 183 & 229 & 222 & 163 & 228 \\ \text { Jul } & 455 & 298 & 201 & 623 & 370 & 379 \\ \text { Aug } & 158 & 298 & 319 & 320 & 230 & 269 \\ \text { Sep } & 44 & 90 & 137 & 193 & 91 & 113 \\ \text { Oct } & 35 & 22 & 90 & 32 & 17 & 40 \\ \text { Nov } & 30 & 20 & 35 & 26 & 19 & 26 \\ \text { Dec } & 45 & 39 & 93 & 41 & 33 & 45\end{array}$

Central Air Conditioner All Regions

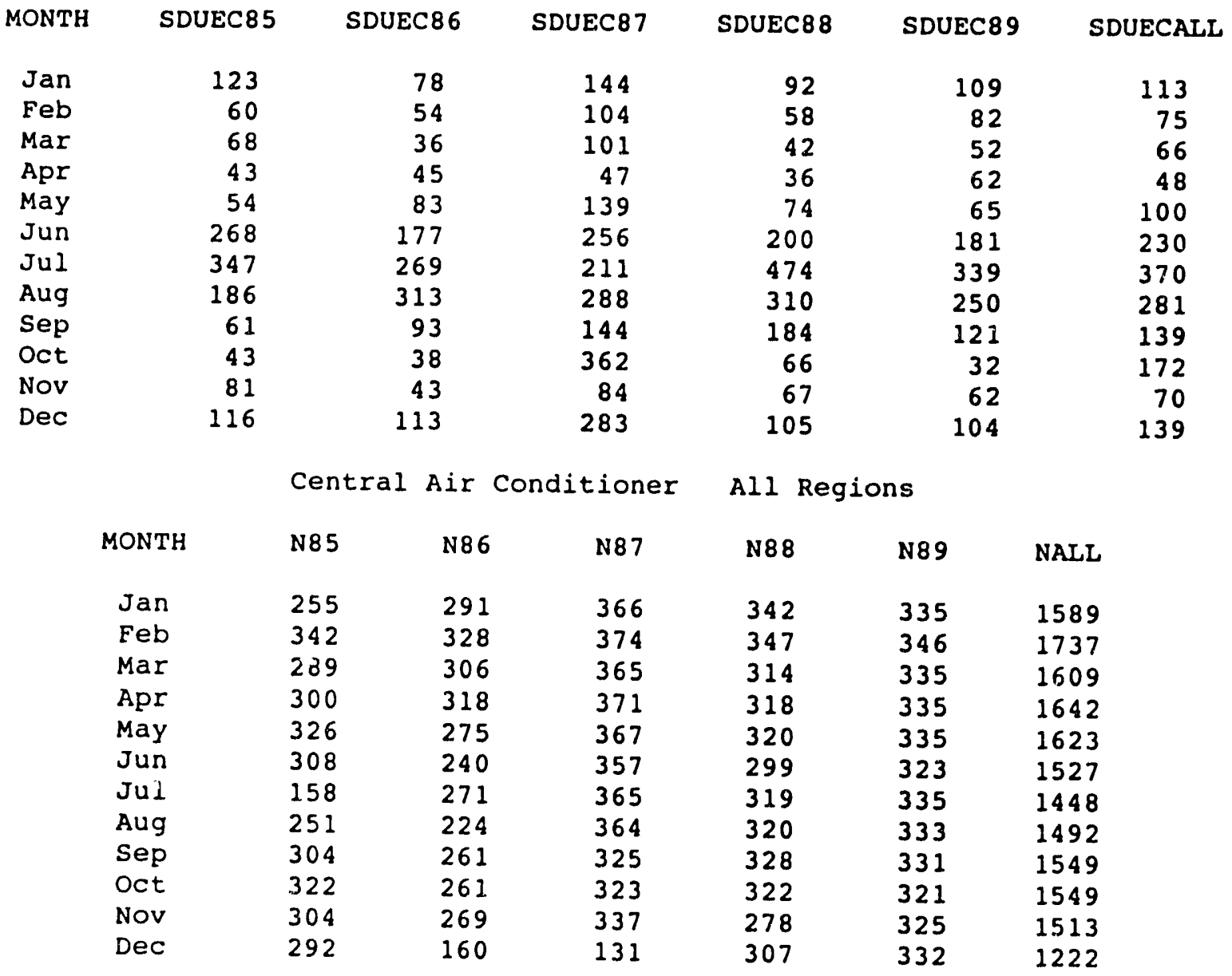




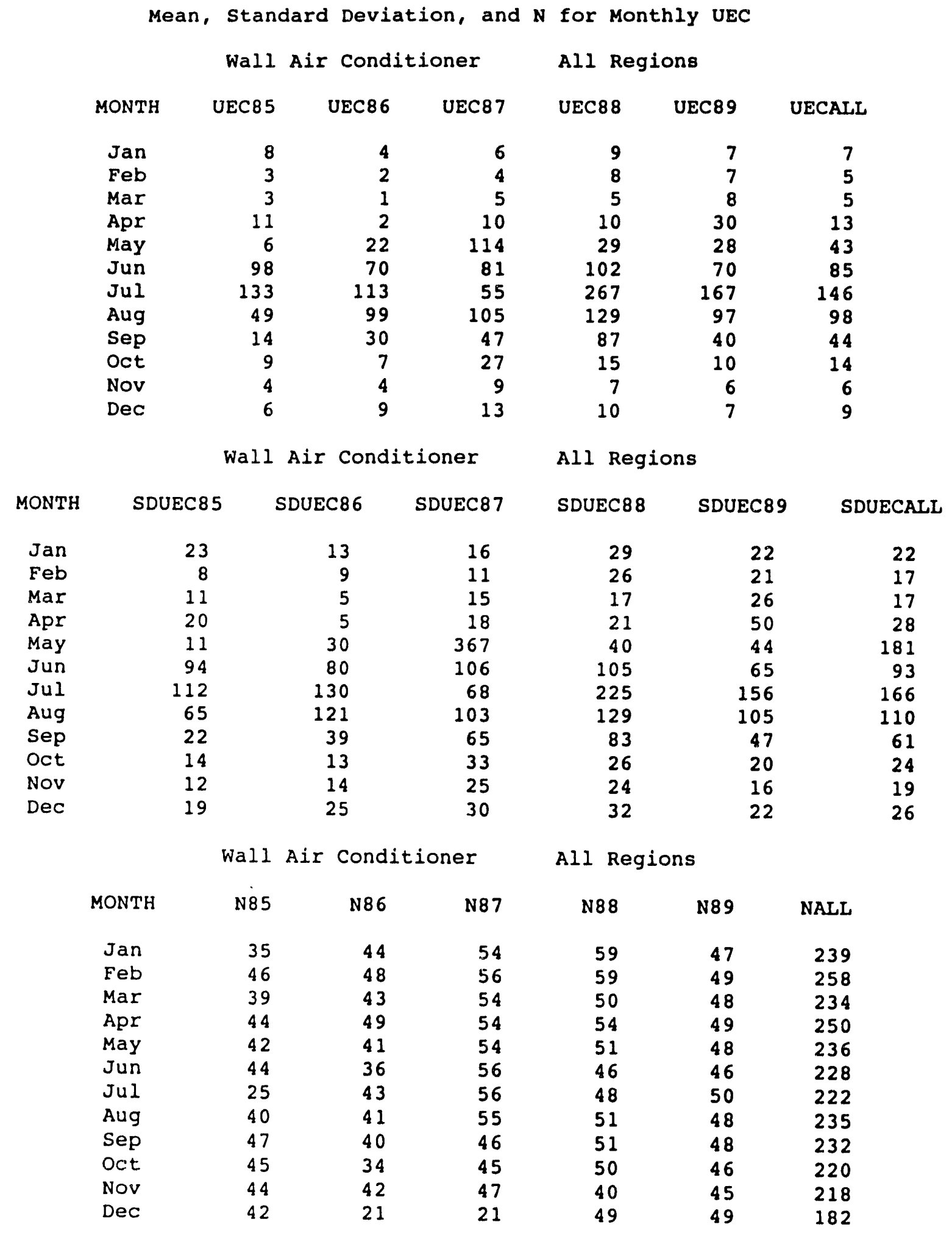


Monthly Mean, Standard Deviation, and $\mathbf{N}$ for UEC

$$
\text { Central Air Conditioner PGE zone R }
$$

$\begin{array}{lrrrrrr}\text { MONTH } & \text { UEC85 } & \text { UEC86 } & \text { UEC87 } & \text { UEC88 } & \text { UEC89 } & \text { UECALL } \\ \text { Jan } & 58 & 37 & 83 & 51 & 59 & 59 \\ \text { Feb } & 37 & 27 & 61 & 35 & 41 & 41 \\ \text { Mar } & 32 & 22 & 55 & 25 & 24 & 33 \\ \text { Apr } & 23 & 17 & 38 & 19 & 39 & 28 \\ \text { May } & 37 & 102 & 173 & 74 & 62 & 92 \\ \text { Jun } & 454 & 302 & 360 & 303 & 252 & 336 \\ \text { Jul } & 669 & 432 & 314 & 880 & 564 & 560 \\ \text { Aug } & 317 & 534 & 481 & 493 & 388 & 448 \\ \text { Sep } & 55 & 144 & 187 & 284 & 158 & 173 \\ \text { Oct } & 30 & 19 & 86 & 41 & 18 & 40 \\ \text { Nov } & 31 & 21 & 50 & 30 & 27 & 33 \\ \text { Dec } & 59 & 45 & 112 & 60 & 53 & 62\end{array}$

Central Air Conditioner PGE zone $R$

$\begin{array}{lrrrrrr}\text { MONTH } & \text { SDUEC85 } & \text { SDUEC86 } & \text { SDUEC87 } & \text { SDUEC88 } & \text { SDUEC89 } & \text { SDUECALL } \\ \text { Jan } & 51 & 32 & 143 & 70 & 72 & 89 \\ \text { Feb } & 34 & 25 & 130 & 49 & 58 & 75 \\ \text { Mar } & 28 & 20 & 134 & 39 & 42 & 73 \\ \text { Apr } & 36 & 20 & 54 & 29 & 53 & 43 \\ \text { May } & 66 & 88 & 146 & 73 & 68 & 107 \\ \text { Jun } & 292 & 202 & 342 & 220 & 231 & 277 \\ \text { Jul } & 389 & 301 & 254 & 497 & 415 & 434 \\ \text { Aug } & 250 & 374 & 347 & 355 & 297 & 336 \\ \text { Sep } & 64 & 102 & 172 & 210 & 153 & 171 \\ \text { Oct } & 33 & 27 & 86 & 64 & 26 & 60 \\ \text { Nov } & 27 & 22 & 88 & 43 & 39 & 53 \\ \text { DeC } & 64 & 44 & 300 & 74 & 65 & 119\end{array}$

Central Air Conditioner PGE zone $\mathbf{R}$

$\begin{array}{lrrrrrr}\text { MONTH } & \text { N85 } & \text { N86 } & \text { N87 } & \text { N88 } & \text { N89 } & \text { NALL } \\ \text { Jan } & 84 & 94 & 130 & 112 & 114 & 534 \\ \text { Feb } & 88 & 96 & 126 & 115 & 116 & 541 \\ \text { Mar } & 84 & 95 & 128 & 108 & 112 & 527 \\ \text { Apr } & 93 & 99 & 129 & 112 & 109 & 542 \\ \text { Mar } & 107 & 87 & 128 & 113 & 111 & 546 \\ \text { Jun } & 98 & 68 & 127 & 114 & 101 & 508 \\ \text { Jul } & 45 & 89 & 126 & 116 & 113 & 489 \\ \text { Aug } & 55 & 58 & 125 & 112 & 113 & 463 \\ \text { Sep } & 89 & 77 & 109 & 114 & 113 & 502 \\ \text { Oct } & 99 & 76 & 111 & 114 & 108 & 508 \\ \text { Nov } & 93 & 86 & 120 & 112 & 109 & 520 \\ \text { Dec } & 94 & 53 & 47 & 112 & 109 & 415\end{array}$


Monthly Mean, Standard Deviation, and $\mathbf{N}$ for UEC

Wall Air Conditioner PGE Zone $R$

$\begin{array}{lrrrrrr}\text { MONTH } & \text { UEC85 } & \text { UEC86 } & \text { UEC87 } & \text { UEC88 } & \text { UEC89 } & \text { UECALL } \\ \text { Jan } & 17 & 0 & 0 & 0 & 1 & 4 \\ \text { Feb } & 0 & 7 & 0 & 0 & 1 & 2 \\ \text { Ma } & 0 & 0 & 0 & 1 & 0 & 0 \\ \text { Apr } & 8 & 0 & 1 & 11 & 59 & 15 \\ \text { Mar } & 10 & 24 & 25 & 40 & 57 & 30 \\ \text { Jun } & 117 & 37 & 53 & 106 & 36 & 70 \\ \text { Jul } & 131 & 155 & 43 & 321 & 142 & 161 \\ \text { Aug } & 32 & 130 & 80 & 141 & 35 & 88 \\ \text { Sep } & 8 & 58 & 35 & 111 & 23 & 44 \\ \text { Oct } & 0 & 10 & 35 & 21 & 1 & 12 \\ \text { Nov } & 0 & 15 & 8 & 1 & 0 & 4 \\ \text { Dec } & 12 & 94 & 12 & 1 & 0 & 10\end{array}$

Wall Air Conditioner PGE zone $R$

$\begin{array}{lrrrrrr}\text { MONTH } & \text { SDUEC85 } & \text { SDUEC86 } & \text { SDUEC87 } & \text { SDUEC88 } & \text { SDUEC89 } & \text { SDUECALL } \\ \text { Jan } & 42 & 0 & 0 & 1 & 1 & 20 \\ \text { Feb } & 0 & 20 & 1 & 1 & 1 & 10 \\ \text { Mar } & 0 & 0 & 0 & 1 & 1 & 1 \\ \text { Apr } & 18 & 0 & 3 & 26 & 131 & 56 \\ \text { May } & 15 & 19 & 41 & 89 & 106 & 60 \\ \text { Jun } & 135 & 61 & 87 & 149 & 63 & 104 \\ \text { Jul } & 146 & 148 & 58 & 281 & 189 & 193 \\ \text { Aug } & 45 & 146 & 99 & 229 & 68 & 138 \\ \text { Sep } & 15 & 69 & 51 & 131 & 35 & 74 \\ \text { Oct } & 0 & 20 & 35 & 42 & 1 & 26 \\ \text { Nov } & 0 & 27 & 18 & 2 & 1 & 12 \\ \text { Dec } & 33 & - & 16 & 1 & 0 & 28\end{array}$

\begin{tabular}{lrrrrrr} 
& \multicolumn{3}{c}{ Wall } & Air & Conditioner & \multicolumn{2}{l}{ PGE Zone R } \\
MONTH & N85 & N86 & N87 & N88 & N89 & NALL \\
Jan & 6 & 6 & 4 & 6 & 4 & 26 \\
Feb & 2 & 7 & 5 & 6 & 5 & 25 \\
Mar & 3 & 6 & 6 & 6 & 5 & 26 \\
Apr & 7 & 6 & 5 & 6 & 5 & 29 \\
May & 6 & 7 & 5 & 6 & 5 & 29 \\
Jun & 5 & 6 & 6 & 6 & 4 & 27 \\
Jul & 4 & 6 & 6 & 6 & 5 & 27 \\
Aug & 4 & 5 & 6 & 6 & 5 & 26 \\
Sep & 7 & 5 & 4 & 5 & 5 & 26 \\
Oct & 6 & 4 & 4 & 5 & 5 & 24 \\
Nov & 6 & 3 & 5 & 5 & 5 & 24 \\
Dec & 7 & 1 & 2 & 5 & 5 & 20
\end{tabular}


Monthly Mean, Standard Deviation, and $N$ for UEC

Central Air conditioner PGE zone $\mathbf{S}$

$\begin{array}{lrrrrrr}\text { MONTH } & \text { UEC85 } & \text { UEC86 } & \text { UEC87 } & \text { UEC88 } & \text { UEC89 } & \text { UECALI } \\ \text { Jan } & 50 & 34 & 60 & 36 & 41 & 44 \\ \text { Feb } & 27 & 27 & 37 & 24 & 32 & 30 \\ \text { Mar } & 29 & 22 & 36 & 19 & 22 & 26 \\ \text { Apr } & 24 & 23 & 27 & 19 & 34 & 26 \\ \text { May } & 31 & 75 & 161 & 47 & 53 & 76 \\ \text { Jun } & 354 & 187 & 203 & 224 & 146 & 225 \\ \text { Jul } & 446 & 309 & 192 & 598 & 348 & 366 \\ \text { Aug } & 145 & 318 & 302 & 283 & 198 & 249 \\ \text { Sep } & 46 & 92 & 137 & 187 & 70 & 107 \\ \text { Oct } & 38 & 25 & 66 & 27 & 17 & 35 \\ \text { Nov } & 36 & 24 & 34 & 30 & 21 & 29 \\ \text { Dec } & 50 & 50 & 113 & 44 & 36 & 53\end{array}$

$\begin{array}{cr}\text { MONTH } & \text { SDUEC } 85 \\ \text { Jan } & 193 \\ \text { Feb } & 90 \\ \text { Mar } & 97 \\ \text { Apr } & 52 \\ \text { May } & 54 \\ \text { Jun } & 262 \\ \text { Jul } & 317 \\ \text { Aug } & 159 \\ \text { Sep } & 69 \\ \text { Oct } & 53 \\ \text { Nov } & 120 \\ \text { Dec } & 172\end{array}$

Central Air Conditioner PGE zone s

$\begin{array}{rrrrr}\text { SDUEC86 } & \text { SDUEC87 } & \text { SDUEC88 } & \text { SDUEC89 } & \text { SDUECALI } \\ 120 & 183 & 130 & 160 & 159 \\ 84 & 103 & 80 & 120 & 96 \\ 50 & 98 & 53 & 72 & 78 \\ 66 & 45 & 45 & 72 & 57 \\ 89 & 143 & 67 & 75 & 105 \\ 171 & 166 & 177 & 154 & 204 \\ 240 & 172 & 394 & 260 & 314 \\ 270 & 224 & 231 & 198 & 226 \\ 91 & 134 & 163 & 95 & 126 \\ 51 & 81 & 67 & 40 & 63 \\ 66 & 101 & 98 & 92 & 98 \\ 184 & 336 & 153 & 155 & 193\end{array}$

Central Air conditioner PGE zone s

$\begin{array}{lrrrrrr}\text { MONTH } & \text { N85 } & \text { N86 } & \text { N87 } & \text { N88 } & \text { N89 } & \text { NALL } \\ \text { Jan } & 96 & 112 & 140 & 129 & 125 & 602 \\ \text { Feb } & 122 & 122 & 142 & 129 & 127 & 642 \\ \text { Mar } & 125 & 128 & 141 & 118 & 125 & 637 \\ \text { Apr } & 124 & 131 & 145 & 119 & 126 & 645 \\ \text { May } & 130 & 99 & 143 & 119 & 124 & 615 \\ \text { Jun } & 124 & 87 & 138 & 108 & 123 & 580 \\ \text { Jul } & 72 & 104 & 143 & 117 & 120 & 556 \\ \text { Aug } & 109 & 86 & 143 & 121 & 122 & 581 \\ \text { Sep } & 129 & 102 & 129 & 123 & 120 & 603 \\ \text { Oct } & 130 & 105 & 128 & 118 & 118 & 599 \\ \text { Nov } & 124 & 93 & 136 & 102 & 122 & 577 \\ \text { Dec } & 112 & 56 & 55 & 111 & 122 & 456\end{array}$


Monthly Mean, Standard Deviation, and $\mathrm{N}$ for UEC

Wall Air Conditioner PGE zone S

$\begin{array}{lrrrrrr}\text { MONTH } & \text { UEC85 } & \text { UEC86 } & \text { UEC87 } & \text { UEC88 } & \text { UEC89 } & \text { UECALL } \\ \text { Jan } & 0 & 2 & 3 & 9 & 0 & 3 \\ \text { Feb } & 0 & 0 & 1 & 2 & 0 & 1 \\ \text { Ma } & 1 & 0 & 2 & 1 & 0 & 1 \\ \text { Apr } & 12 & 1 & 7 & 4 & 18 & 8 \\ \text { Ma } & 3 & 47 & 91 & 25 & 25 & 39 \\ \text { Jun } & 136 & 131 & 143 & 166 & 94 & 134 \\ \text { Jul } & 184 & 189 & 96 & 437 & 268 & 241 \\ \text { Aug } & 99 & 191 & 177 & 193 & 160 & 168 \\ \text { Sep } & 16 & 46 & 74 & 128 & 53 & 67 \\ \text { Oct } & 6 & 6 & 31 & 12 & 7 & 12 \\ \text { Nov } & 2 & 0 & 8 & 1 & 1 & 2 \\ \text { Dec } & 6 & 3 & 1 & 1 & 1 & 2\end{array}$

Wall Air conditioner PGE zone $\mathbf{s}$

MONTH SDUEC85

SDUEC


4
10
17
14
3
1
SDUEC87 SDUEC88

SDUEC89

SDUECALI

$\begin{array}{lr}\text { Jan } & 1 \\ \text { Feb } & 1 \\ \text { Mar } & 4 \\ \text { Apr } & 24 \\ \text { May } & 4 \\ \text { Jun } & 126 \\ \text { Jun } & 123 \\ \text { Aug } & 87 \\ \text { Sep } & 24 \\ \text { Oct } & 11 \\ \text { Nov } & 7 \\ \text { Dec } & 22\end{array}$

6
2
1
4
44
101
170
146
35
13
1
6

9
1
5
12
88
135
92
128
96
38
32
2

39
9
2
6
24
130
241
136
96
24
3
3

1
1
1
27
34
86
180
129
59
13
4
4

21

Wall Air Conditioner PGE zone s

$\begin{array}{lrrrrrr}\text { MONTH } & \text { N85 } & \text { N86 } & \text { N87 } & \text { N88 } & \text { N89 } & \text { NALL } \\ \text { Jan } & 7 & 13 & 16 & 20 & 17 & 73 \\ \text { Feb } & 12 & 13 & 15 & 20 & 17 & 77 \\ \text { Mar } & 13 & 12 & 15 & 17 & 17 & 74 \\ \text { Apr } & 13 & 15 & 16 & 19 & 17 & 80 \\ \text { May } & 12 & 10 & 16 & 18 & 17 & 73 \\ \text { Jun } & 12 & 9 & 16 & 15 & 16 & 68 \\ \text { Jul } & 8 & 12 & 16 & 15 & 18 & 69 \\ \text { Aug } & 10 & 13 & 16 & 17 & 18 & 74 \\ \text { Sep } & 13 & 12 & 12 & 18 & 18 & 73 \\ \text { Oct } & 13 & 9 & 12 & 20 & 18 & 72 \\ \text { Nov } & 13 & 13 & 15 & 20 & 18 & 79 \\ \text { Dec } & 13 & 3 & 3 & 19 & 18 & 56\end{array}$


Monthly Mean, Standard Deviation, and $N$ for UEC Central Air conditioner PGE zone $\mathbf{x}$

$\begin{array}{lrrrrrr}\text { MONTH } & \text { UEC85 } & \text { UEC86 } & \text { UEC87 } & \text { UEC88 } & \text { UEC89 } & \text { UECALI } \\ \text { Jan } & 15 & 15 & 16 & 7 & 8 & 12 \\ \text { Feb } & 12 & 13 & 14 & 7 & 7 & 10 \\ \text { Mar } & 16 & 14 & 16 & 9 & 6 & 12 \\ \text { Apr } & 24 & 16 & 24 & 16 & 38 & 24 \\ \text { May } & 20 & 33 & 116 & 49 & 30 & 50 \\ \text { Jun } & 177 & 84 & 86 & 102 & 94 & 108 \\ \text { JuI } & 238 & 133 & 66 & 314 & 181 & 178 \\ \text { Aug } & 74 & 105 & 132 & 149 & 88 & 110 \\ \text { Sep } & 31 & 34 & 73 & 89 & 38 & 53 \\ \text { Oct } & 35 & 19 & 131 & 28 & 14 & 44 \\ \text { Nov } & 19 & 13 & 15 & 11 & 6 & 13 \\ \text { Dec } & 21 & 18 & 22 & 11 & 9 & 15\end{array}$

$\begin{array}{lrrrrrr}\text { MONTH } & \text { SDUEC85 } & \text { SDUEC86 } & \text { SDUEC87 } & \text { SDUEC88 } & \text { SDUEC89 } & \text { SDUECALL } \\ \text { Jan } & 23 & 21 & 22 & 20 & 25 & 22 \\ \text { Feb } & 17 & 19 & 18 & 16 & 19 & 18 \\ \text { Mar } & 27 & 20 & 20 & 20 & 16 & 21 \\ \text { Apr } & 34 & 21 & 35 & 27 & 57 & 38 \\ \text { May } & 33 & 50 & 115 & 80 & 40 & 79 \\ \text { Jun } & 140 & 77 & 88 & 128 & 102 & 114 \\ \text { JuI } & 161 & 156 & 79 & 323 & 175 & 215 \\ \text { Aug } & 80 & 138 & 125 & 225 & 115 & 146 \\ \text { Sep } & 38 & 46 & 80 & 102 & 55 & 72 \\ \text { Oct } & 37 & 24 & 701 & 66 & 25 & 309 \\ \text { Nov } & 35 & 19 & 19 & 24 & 13 & 23 \\ \text { DeC } & 47 & 27 & 23 & 32 & 24 & 33\end{array}$

\section{Central Air Conditioner PGE zone $\mathrm{x}$}

$\begin{array}{lrrrrrr}\text { MONTH } & \text { N85 } & \text { N86 } & \text { N87 } & \text { N88 } & \text { N89 } & \text { NALL } \\ \text { Jan } & 74 & 84 & 95 & 100 & 95 & 448 \\ \text { Feb } & 75 & 75 & 96 & 102 & 98 & 446 \\ \text { Mar } & 79 & 82 & 95 & 88 & 97 & 441 \\ \text { Apr } & 82 & 87 & 96 & 86 & 99 & 450 \\ \text { May } & 88 & 88 & 95 & 87 & 99 & 457 \\ \text { Jun } & 85 & 84 & 91 & 76 & 98 & 434 \\ \text { Jul } & 40 & 77 & 95 & 85 & 101 & 398 \\ \text { Aug } & 86 & 79 & 95 & 86 & 97 & 443 \\ \text { Sep } & 86 & 81 & 86 & 90 & 97 & 440 \\ \text { Oct } & 92 & 79 & 83 & 89 & 94 & 437 \\ \text { Nov } & 86 & 89 & 80 & 64 & 93 & 412 \\ \text { Dec } & 85 & 50 & 29 & 83 & 100 & 347\end{array}$


Monthly Mean, Standard Deviation, and $\mathrm{N}$ for UEC

Wall Air Conditioner PGE zone $x$

$\begin{array}{lrrrrrr}\text { MONTH } & \text { UEC85 } & \text { UEC86 } & \text { UEC87 } & \text { UEC88 } & \text { UEC89 } & \text { UECALL } \\ \text { Jan } & 8 & 6 & 8 & 11 & 13 & 9 \\ \text { Feb } & 5 & 2 & 6 & 12 & 12 & 8 \\ \text { Mar } & 5 & 2 & 7 & 9 & 15 & 8 \\ \text { Apr } & 11 & 2 & 12 & 14 & 33 & 14 \\ \text { May } & 6 & 11 & 138 & 30 & 25 & 48 \\ \text { Jun } & 78 & 54 & 57 & 63 & 60 & 63 \\ \text { Jul } & 103 & 66 & 38 & 161 & 104 & 91 \\ \text { Aug } & 32 & 40 & 74 & 88 & 64 & 61 \\ \text { Sep } & 14 & 16 & 37 & 55 & 33 & 32 \\ \text { Oct } & 13 & 7 & 24 & 15 & 14 & 15 \\ \text { Nov } & 6 & 5 & 9 & 18 & 10 & 9 \\ \text { Dec } & 4 & 5 & 15 & 20 & 13 & 12\end{array}$

Wall Air Conditioner PGE zone $x$

$\begin{array}{lrrrrrr}\text { MONTH } & \text { SDUEC85 } & \text { SDUEC86 } & \text { SDUEC87 } & \text { SDUEC88 } & \text { SDUEC89 } & \text { SDUECALL } \\ \text { Jan } & 19 & 17 & 19 & 25 & 29 & 22 \\ \text { Feb } & 11 & 6 & 14 & 34 & 28 & 22 \\ \text { Mar } & 14 & 6 & 18 & 23 & 34 & 21 \\ \text { Apr } & 19 & 6 & 21 & 25 & 35 & 25 \\ \text { May } & 12 & 18 & 466 & 33 & 31 & 236 \\ \text { Jun } & 63 & 62 & 82 & 48 & 46 & 63 \\ \text { Jul } & 92 & 79 & 47 & 128 & 88 & 98 \\ \text { Aug } & 47 & 48 & 70 & 77 & 63 & 66 \\ \text { Sep } & 22 & 25 & 48 & 47 & 37 & 41 \\ \text { Oct } & 17 & 12 & 31 & 24 & 25 & 24 \\ \text { Nov } & 15 & 16 & 22 & 37 & 22 & 22 \\ \text { Dec } & 10 & 18 & 34 & 44 & 30 & 30\end{array}$

Wall Air Conditioner PGE zone $x$

$\begin{array}{lrrrrrr}\text { MONTH } & \text { N85 } & \text { N86 } & \text { N87 } & \text { N88 } & \text { N89 } & \text { NALL } \\ \text { Jan } & 22 & 25 & 34 & 33 & 26 & 140 \\ \text { Feb } & 22 & 23 & 34 & 33 & 27 & 139 \\ \text { Mar } & 23 & 25 & 33 & 27 & 26 & 134 \\ \text { Apr } & 24 & 28 & 33 & 29 & 27 & 141 \\ \text { May } & 24 & 24 & 33 & 27 & 26 & 134 \\ \text { Jun } & 27 & 21 & 34 & 25 & 26 & 133 \\ \text { Jul } & 13 & 25 & 34 & 27 & 27 & 126 \\ \text { Aug } & 26 & 23 & 33 & 28 & 25 & 135 \\ \text { Sep } & 27 & 23 & 30 & 28 & 25 & 133 \\ \text { Oct } & 26 & 21 & 29 & 25 & 23 & 124 \\ \text { Nov } & 25 & 26 & 27 & 15 & 22 & 115 \\ \text { Dec } & 22 & 17 & 16 & 25 & 26 & 106\end{array}$




\section{Appendix C \\ Data Tables for Chapter 5}




\begin{tabular}{|c|c|c|c|c|c|c|c|c|c|c|c|c|}
\hline & Tab & B C1: & $\begin{array}{r}\text { Centra } \\
\text { Mean }\end{array}$ & Alr & $\begin{array}{l}\text { Cond } \\
\text { in } k\end{array}$ & $\begin{array}{l}\text { oner } \\
h \text { h for }\end{array}$ & $\begin{array}{l}\text { Raw } \\
\text { all }\end{array}$ & CEC & & & Matrix & \\
\hline \multicolumn{2}{|c|}{ hour $\rightarrow 1$} & 2 & 3 & 4 & 5 & 6 & 7 & 8 & 9 & 10 & 11 & 12 \\
\hline 45 & 0.041 & 0.043 & 0.046 & 0.048 & 0.049 & 0.063 & 0.090 & 0.098 & 0.088 & 0.097 & 0.096 & 0.092 \\
\hline 46 & 0.041 & 0.040 & 0.045 & 0.045 & 0.050 & 0.061 & 0.099 & 0.100 & 0.094 & 0.078 & 0.088 & 0.099 \\
\hline 47 & 0.039 & 0.040 & 0.041 & 0.045 & 0.048 & 0.058 & 0.081 & 0.091 & 0.080 & 0.086 & 0.085 & 0.088 \\
\hline 48 & 0.034 & 0.036 & 0.038 & 0.041 & 0.041 & 0.050 & 0.073 & 0.087 & 0.093 & 0.069 & 0.079 & 0.083 \\
\hline 49 & 0.035 & 0.034 & 0.036 & 0.035 & 0.041 & 0.050 & 0.071 & 0.078 & 0.074 & 0.073 & 0.068 & 0.069 \\
\hline 50 & 0.031 & 0.034 & 0.031 & 0.036 & 0.038 & 0.049 & 0.063 & 0.074 & 0.072 & 0.080 & 0.062 & 0.074 \\
\hline 51 & 0.032 & 0.029 & 0.031 & 0.031 & 0.033 & 0.043 & 0.065 & 0.068 & 0.061 & 0.062 & 0.067 & 0.059 \\
\hline 52 & 0.027 & 0.028 & 0.029 & 0.029 & 0.032 & 0.036 & 0.061 & 0.064 & 0.057 & 0.054 & 0.058 & 0.061 \\
\hline 53 & 0.02 & 0.027 & 0.026 & 0.028 & 0.029 & 0.03 & 0.048 & 0.055 & 0.056 & 0.055 & 0.054 & 0.050 \\
\hline 54 & 0.025 & 0.023 & 0.024 & 0.02 & 0.025 & 0.028 & 0.040 & 0.045 & 0.045 & 0.051 & 0.044 & 0.051 \\
\hline 55 & 0.024 & 0.023 & 0.023 & 0.023 & 0.025 & 0.026 & 0.033 & 0.038 & 0.041 & 0.043 & 0.043 & 0.044 \\
\hline 56 & 0.021 & 0.021 & 0.019 & 0.020 & 0.020 & 0.024 & 0.035 & 0.036 & 0.037 & 0.035 & 0.039 & 0.039 \\
\hline 57 & 0.019 & 0.019 & 0.018 & 0.019 & 0.021 & 0.024 & 0.029 & 0.029 & 0.030 & 0.033 & 0.035 & 0.036 \\
\hline 58 & 0.018 & 0.019 & 0.020 & 0.021 & 0.018 & 0.019 & 0.022 & 0.027 & 0.026 & 0.033 & 0.031 & 0.032 \\
\hline 59 & 0.022 & 0.022 & 0.021 & 0.020 & 0.021 & 0.020 & 0.024 & 0.025 & 0.025 & 0.028 & 0.029 & 0.028 \\
\hline 60 & 0.026 & 0.024 & 0.020 & 0.021 & 0.018 & 0.020 & 0.026 & 0.026 & 0.026 & 0.026 & 0.027 & 0.028 \\
\hline 61 & 0.027 & 0.025 & 0.023 & 0.020 & 0.023 & 0.024 & 0.024 & 0.027 & 0.028 & 0.026 & 0.025 & 0.025 \\
\hline 62 & 0.031 & 0.028 & 0.026 & 0.030 & 0.023 & 0.025 & 0.025 & 0.027 & 0.025 & 0.023 & 0.025 & 0.024 \\
\hline 63 & 0.039 & 0.037 & 0.032 & 0.030 & 0.029 & 0.026 & 0.028 & 0.031 & 0.031 & 0.026 & 0.023 & 0.022 \\
\hline 64 & 0.047 & 0.044 & 0.039 & 0.037 & 0.032 & 0.031 & 0.028 & 0.034 & 0.032 & 0.033 & 0.022 & 0.022 \\
\hline 65 & 0.068 & 0.048 & 0.049 & 0.042 & 0.036 & 0.037 & 0.039 & 0.046 & 0.046 & 0.037 & 0.030 & 0.024 \\
\hline 66 & 0.067 & 0.068 & 0.051 & 0.049 & 0.052 & 0.050 & 0.048 & 0.057 & 0.048 & 0.047 & 0.042 & 0.026 \\
\hline 67 & 0.105 & 0.085 & 0.082 & 0.076 & 0.061 & 0.058 & 0.065 & 0.070 & 0.059 & 0.060 & 0.044 & 0.039 \\
\hline 68 & 0.114 & 0.101 & 0.091 & 0.088 & 0.085 & 0.073 & 0.078 & 0.083 & 0.079 & 0.074 & 0.067 & 0.052 \\
\hline 69 & 0.154 & 0.141 & 0.116 & 0.106 & 0.095 & 0.093 & 0.098 & 0.111 & 0.091 & 0.085 & 0.081 & 0.064 \\
\hline 70 & 0.171 & 0.137 & 0.135 & 0.139 & 0.135 & 0.126 & 0.111 & 0.139 & 0.153 & 0.113 & 0.108 & 0.089 \\
\hline 71 & 0.190 & 0.183 & 0.172 & 0.176 & 0.153 & 0.152 & 0.153 & 0.154 & 0.137 & 0.108 & 0.108 & 0.115 \\
\hline 72 & 0.251 & 0.241 & 0.240 & 0.238 & 0.197 & 0.190 & 0.195 & 0.210 & 0.193 & 0.177 & 0.129 & 0.142 \\
\hline 73 & 0.316 & 0.305 & 0.285 & 0.257 & 0.240 & 0.264 & 0.249 & 0.257 & 0.212 & 0.194 & 0.163 & 0.183 \\
\hline 74 & 0.377 & 0.383 & 0.355 & 0.368 & 0.287 & 0.239 & 0.146 & 0.323 & 0.397 & 0.268 & 0.216 & 0.191 \\
\hline 75 & 0.459 & 0.439 & 0.421 & 0.358 & 0.426 & .nd & .nd & .nd & 0.360 & 0.311 & 0.294 & 0.251 \\
\hline 76 & 0.559 & 0.516 & 0.317 & 0.368 & .nd & .nd & .nd & .nd & 0.542 & 0.382 & 0.370 & 0.347 \\
\hline 77 & 0.692 & 0.550 & 0.620 & .nd & .nd & .nd & .nd & .nd & 0.534 & 0.614 & 0.458 & 0.477 \\
\hline 78 & 0.822 & 0.844 & .nd & .nd & .nd & .nd & .nd & .nd & .nd & 0.706 & 0.554 & 0.602 \\
\hline 79 & 1.016 & 0.859 & .nd & .nd & .nd & .nd & .nd & .nd & .nd & 0.821 & 0.763 & 0.729 \\
\hline 80 & .nd & .nd & .nd & .nd & .nd & .nd & .nd & .nd & .nd & .nd & 1.007 & 0.893 \\
\hline 81 & .nd & .nd & .nd & .nd & .nd & .nd & .nd & .nd & .nd & .nd & .nd & 1.172 \\
\hline 82 & .nd & .nd & .nd & .nd & .nd & .nd & .nd & .nd & .nd & .nd & .nd & 1.097 \\
\hline 83 & .nd & .nd & .nd & .nd & .nd & .nd & .nd & .nd & .nd & .nd & .nd & 1.425 \\
\hline 84 & .nd & .nd & .nd & .nd & .nd & .nd & .nd & .nd & .nd & .nd & .nd & .nd \\
\hline 85 & .nd & .nd & .nd & .nd & .nd & .nd & .nd & .nd & .nd & .nd & .nd & .nd \\
\hline 86 & .nd & .nd & .nd & .nd & .nd & .nd & .nd & .nd & .nd & .nd & .nd & .nd \\
\hline 8 & .nd & .nd & .nd & .nd & .nd & .nd & .nd & .nd & .nd & .nd & .nd & .nd \\
\hline 88 & .nd & .nd & .nd & .nd & .nd & .nd & .nd & .nd & .nd & .nd & .nd & .nd \\
\hline 89 & .nd & .nd & .nd & .nd & .nd & .nd & .nd & .nd & .nd & .nd & .nd & .nd \\
\hline
\end{tabular}

.nd = no data available 


\begin{tabular}{|c|c|c|c|c|c|c|c|c|c|c|c|c|}
\hline \multirow{2}{*}{\multicolumn{2}{|c|}{ hour $\rightarrow 1$}} & \multirow{2}{*}{$\begin{array}{l}1 \text { cont'd } \\
2\end{array}$} & \multirow{2}{*}{\multicolumn{3}{|c|}{$\begin{array}{l}\text { d: Central Air C } \\
\text { Mean Load in } \\
3 \quad 4 \quad 5\end{array}$}} & \multirow{2}{*}{$\begin{array}{c}\text { onditione } \\
\text { kWh for } \\
6\end{array}$} & \multicolumn{2}{|c|}{$\begin{array}{l}\text { er Raw } \\
\text { all CEC }\end{array}$} & \multicolumn{2}{|c|}{$\begin{array}{l}\text { Timu-Temperature } \\
\text { Regions }\end{array}$} & \multicolumn{2}{|c|}{ Matrix } \\
\hline & & & & & & & 7 & 8 & 9 & 10 & 11 & 12 \\
\hline 45 & 0.099 & 0.084 & 0.095 & 0.083 & 0.097 & 0.098 & 0.094 & 0.100 & 0.092 & 0.076 & 0.063 & 0.047 \\
\hline 46 & 0.085 & 0.084 & 0.091 & 0.091 & 0.077 & 0.083 & 0.090 & 0.082 & 0.083 & 0.066 & 0.055 & 0.045 \\
\hline 47 & 0.089 & 0.076 & 0.063 & 0.075 & 0.085 & 0.104 & 0.089 & $0.080^{\circ}$ & 0.067 & 0.068 & 0.053 & 0.043 \\
\hline 48 & 0.070 & 0.087 & 0.079 & 0.077 & 0.093 & 0.077 & 0.085 & 0.077 & 0.067 & 0.063 & 0.052 & 0.041 \\
\hline 49 & 0.075 & 0.069 & 0.077 & 0.088 & 0.080 & 0.083 & 0.072 & 0.069 & 0.065 & 0.055 & 0.049 & 0.038 \\
\hline 50 & 0.060 & 0.063 & 0.073 & 0.068 & 0.071 & 0.076 & 0.068 & 0.065 & 0.062 & 0.054 & 0.048 & 0.036 \\
\hline 51 & 0.066 & 0.064 & 0.062 & 0.067 & 0.068 & 0.069 & 0.072 & 0.060 & 0.054 & 0.052 & 0.042 & 0.034 \\
\hline 52 & 0.057 & 0.062 & 0.054 & 0.055 & 0.065 & 0.065 & 0.063 & 0.053 & 0.053 & 0.049 & 0.040 & 0.032 \\
\hline 53 & 0.055 & 0.055 & 0.053 & 0.055 & 0.058 & 0.062 & 0.053 & 0.051 & 0.051 & 0.044 & 0.036 & 0.030 \\
\hline 54 & 0.047 & 0.048 & 0.047 & 0.047 & 0.050 & 0.059 & 0.056 & 0.050 & 0.046 & 0.037 & 0.032 & 0.027 \\
\hline 55 & 0.045 & 0.044 & 0.046 & 0.045 & 0.051 & 0.051 & 0.047 & 0.045 & 0.040 & 0.035 & 0.030 & 0.025 \\
\hline 56 & 0.040 & 0.043 & 0.040 & 0.047 & 0.045 & 0.047 & 0.051 & 0.039 & 0.037 & 0.031 & 0.028 & 0.024 \\
\hline 57 & 0.035 & 0.035 & 0.036 & 0.038 & 0.039 & 0.047 & 0.039 & 0.038 & 0.032 & 0.029 & 0.025 & 0.021 \\
\hline 58 & 0.035 & 0.033 & 0.036 & 0.033 & 0.043 & 0.040 & 0.036 & 0.030 & 0.028 & 0.025 & 0.023 & 0.020 \\
\hline 59 & 0.030 & 0.031 & 0.031 & 0.034 & 0.035 & 0.037 & 0.033 & 0.029 & 0.029 & 0.026 & 0.026 & 0.024 \\
\hline 60 & 0.026 & 0.028 & 0.030 & 0.030 & 0.034 & 0.033 & 0.033 & 0.030 & 0.029 & 0.032 & 0.025 & 0.021 \\
\hline 61 & 0.027 & 0.026 & 0.027 & 0.027 & 0.029 & 0.030 & 0.028 & 0.027 & 0.030 & 0.034 & 0.033 & 0.031 \\
\hline 62 & 0.022 & 0.025 & 0.023 & 0.024 & 0.026 & 0.032 & 0.031 & 0.031 & 0.035 & 0.038 & 0.039 & 0.032 \\
\hline 63 & 0.021 & 0.022 & 0.025 & 0.024 & 0.027 & 0.031 & 0.032 & 0.037 & 0.043 & 0.048 & 0.047 & 0.044 \\
\hline 64 & 0.022 & 0.023 & 0.022 & 0.023 & 0.030 & 0.032 & 0.037 & 0.042 & 0.050 & 0.062 & 0.063 & 0.061 \\
\hline 65 & 0.024 & 0.023 & 0.021 & 0.026 & 0.026 & 0.034 & 0.041 & 0.059 & 0.069 & 0.090 & 0.090 & 0.080 \\
\hline 66 & 0.021 & 0.024 & 0.024 & 0.028 & 0.036 & 0.044 & 0.073 & 0.065 & 0.077 & 0.115 & 0.125 & 0.100 \\
\hline 67 & 0.033 & 0.027 & 0.031 & 0.034 & 0.050 & 0.058 & 0.075 & 0.099 & 0.131 & 0.157 & 0.161 & 0.105 \\
\hline 68 & 0.040 & 0.044 & 0.044 & 0.056 & 0.061 & 0.089 & 0.122 & 0.143 & 0.182 & 0.188 & 0.170 & 0.153 \\
\hline 69 & 0.052 & 0.040 & 0.052 & 0.061 & 0.076 & 0.106 & 0.153 & 0.201 & 0.232 & 0.242 & 0.206 & 0.174 \\
\hline 70 & 0.076 & 0.072 & 0.061 & 0.066 & 0.100 & 0.173 & 0.174 & 0.256 & 0.321 & 0.276 & 0.240 & 0.223 \\
\hline 71 & 0.108 & 0.087 & 0.090 & 0.112 & 0.152 & 0.207 & 0.315 & 0.316 & 0.288 & 0.312 & 0.304 & 0.252 \\
\hline 72 & 0.112 & 0.122 & 0.154 & 0.161 & 0.245 & 0.304 & 0.330 & 0.368 & 0.402 & 0.379 & 0.356 & 0.259 \\
\hline 73 & 0.170 & 0.178 & 0.170 & 0.235 & 0.281 & 0.358 & 0.414 & 0.499 & 0.451 & 0.502 & 0.400 & 0.351 \\
\hline 74 & 0.219 & 0.191 & 0.237 & 0.285 & 0.365 & 0.452 & 0.533 & 0.450 & 0.491 & 0.573 & 0.487 & 0.413 \\
\hline 75 & 0.284 & 0.273 & 0.277 & 0.360 & 0.415 & 0.494 & 0.561 & 0.579 & 0.673 & 0.643 & 0.591 & 0.487 \\
\hline 76 & 0.303 & 0.380 & 0.374 & 0.354 & 0.490 & 0.583 & 0.614 & 0.671 & 0.685 & 0.851 & 0.757 & 0.638 \\
\hline 77 & 0.4 & 0.454 & 0.562 & 0.574 & 0.579 & 0.660 & 0.807 & 0.852 & 0.943 & 1.029 & 0.899 & 0.720 \\
\hline 78 & 0.539 & 0.585 & 0.581 & 0.696 & 0.806 & 0.876 & 0.974 & 0.956 & 1.152 & 1.182 & 1.075 & 0.847 \\
\hline 79 & 0.751 & 0.670 & 0.763 & 0.824 & 0.915 & 1.083 & 1.122 & 1.180 & 1.317 & 1.424 & 1.202 & 1.046 \\
\hline 80 & 0.881 & 0.861 & 0.896 & 1.015 & 1.154 & 1.192 & 1.339 & 1.427 & 1.449 & 1.630 & 1.414 & 1.195 \\
\hline 81 & 1.069 & 1.097 & 1.037 & 1.179 & 1.321 & 1.479 & 1.587 & 1.629 & 1.756 & 1.854 & 1.790 & .nd \\
\hline 82 & 1.344 & 1.311 & 1.353 & 1.396 & 1.490 & 1.679 & 1.811 & 1.841 & 1.985 & 2.053 & 1.709 & .nd \\
\hline 83 & 1.503 & 1.496 & 1.608 & 1.604 & 1.761 & 1.890 & 2.085 & 2.087 & 2.135 & 2.276 & .nd & .nd \\
\hline 84 & 1.770 & 1.832 & 1.756 & 1.914 & 1.965 & 2.187 & 2.343 & 2.358 & 2.495 & .nd & .nd & .nd \\
\hline 85 & 1.888 & 1.983 & 2.073 & 2.128 & 2.262 & 2.444 & 2.596 & 2.560 & 2.671 & .nd & .nd & .nd \\
\hline 86 & .nd & 2.122 & 2.397 & 2.607 & 2.541 & 2.696 & 2.793 & 2.966 & .nd & .nd & .nd & .nd \\
\hline 87 & .nd & .nd & .nd & 2.664 & 2.880 & 2.985 & 3.075 & 2.984 & .nd & .nd & .nd & .nd \\
\hline 88 & .nd & .nd & .nd & 2.474 & 2.868 & 2.973 & 2.908 & .nd & .nd & .nd & .nd & .nd \\
\hline 89 & .nd & .nd & .nd & .nd & 3.069 & 3.193 & 3.328 & .nd & .nd & .nd & .nd & .nd \\
\hline
\end{tabular}

.nd = no data available 


\begin{tabular}{|c|c|c|c|c|c|c|c|c|c|c|c|c|}
\hline & Tabl & e C2: & $\begin{array}{r}\text { Centra } \\
\text { Mea }\end{array}$ & $\begin{array}{l}\text { Air } \\
\text { Loa }\end{array}$ & & $\begin{array}{l}\text { itioner } \\
\text { kWh }\end{array}$ & for CF & & & & Matrix & \\
\hline \multicolumn{2}{|c|}{ hour $\rightarrow 1$} & 2 & 3 & 4 & 5 & 6 & 7 & 8 & 9 & 10 & 11 & 12 \\
\hline 45 & 0.031 & 0.037 & 0.038 & 0.039 & 0.043 & 0.047 & $0.0 \%$ & 0.089 & 0.085 & 0.074 & 0.081 & 0.082 \\
\hline 46 & 0.036 & 0.035 & 0.040 & 0.030 & 0.041 & 0.049 & 0.083 & 0.095 & 0.083 & 0.084 & 0.077 & 0.082 \\
\hline 47 & 0.031 & 0.029 & 0.034 & 0.042 & 0.047 & 0.052 & 0.074 & 0.079 & 0.077 & 0.078 & 0.069 & 0.084 \\
\hline 48 & 0.027 & 0.030 & 0.032 & 0.039 & 0.034 & 0.039 & 0.066 & 0.078 & 0.077 & 0.068 & 0.076 & 0.065 \\
\hline 49 & 0.028 & 0.029 & 0.031 & 0.031 & 0.032 & 0.041 & 0.055 & 0.073 & 0.069 & 0.071 & 0.065 & 0.067 \\
\hline 50 & 0.025 & 0.025 & 0.025 & 0.027 & 0.029 & 0.034 & 0.053 & 0.064 & 0.063 & 0.080 & 0.060 & 0.072 \\
\hline 51 & 0.024 & 0.025 & 0.024 & 0.025 & 0.028 & 0.034 & 0.046 & 0.062 & 0.060 & 0.064 & 0.059 & 0.056 \\
\hline 52 & 0.021 & 0.022 & 0.023 & 0.024 & 0.027 & 0.031 & 0.055 & 0.060 & 0.056 & 0.059 & 0.064 & 0.060 \\
\hline 53 & 0.024 & 0.024 & 0.021 & 0.024 & 0.025 & 0.028 & 0.038 & 0.053 & 0.053 & 0.051 & 0.053 & 0.058 \\
\hline 54 & 0.019 & 0.018 & 0.020 & 0.020 & 0.019 & 0.021 & 0.032 & 0.040 & 0.042 & 0.050 & 0.052 & 0.058 \\
\hline 55 & 0.017 & 0.019 & 0.017 & 0.019 & 0.020 & 0.022 & 0.029 & 0.035 & 0.044 & 0.042 & 0.055 & 0.050 \\
\hline 56 & 0.017 & 0.016 & 0.015 & 0.016 & 0.016 & 0.017 & 0.024 & 0.030 & 0.038 & 0.039 & 0.040 & 0.059 \\
\hline 57 & 0.016 & 0.016 & 0.015 & 0.015 & 0.019 & 0.023 & 0.028 & 0.025 & 0.031 & 0.032 & 0.037 & 0.041 \\
\hline 58 & 0.015 & 0.016 & 0.017 & 0.016 & 0.020 & 0.017 & 0.021 & 0.037 & 0.034 & 0.043 & 0.032 & 0.038 \\
\hline 59 & 0.024 & 0.020 & 0.025 & 0.025 & 0.018 & 0.018 & 0.017 & 0.021 & 0.022 & 0.029 & 0.038 & 0.030 \\
\hline 60 & 0.029 & 0.038 & 0.024 & 0.019 & 0.018 & 0.023 & 0.028 & 0.021 & 0.020 & 0.022 & 0.024 & 0.038 \\
\hline 61 & 0.034 & 0.031 & 0.026 & 0.025 & 0.023 & 0.021 & 0.023 & 0.028 & 0.027 & 0.021 & 0.023 & 0.024 \\
\hline 62 & 0.048 & 0.034 & 0.030 & 0.031 & 0.027 & 0.023 & 0.027 & 0.026 & 0.024 & 0.018 & 0.021 & 0.023 \\
\hline 63 & 0.052 & 0.043 & 0.039 & 0.035 & 0.030 & 0.033 & 0.036 & 0.035 & 0.030 & 0.025 & 0.019 & 0.021 \\
\hline 64 & 0.082 & 0.067 & 0.056 & 0.050 & 0.056 & 0.045 & 0.041 & 0.044 & 0.032 & 0.023 & 0.021 & 0.019 \\
\hline 65 & 0.097 & 0.084 & 0.079 & 0.066 & 0.061 & 0.051 & 0.073 & 0.057 & 0.037 & 0.028 & 0.022 & 0.019 \\
\hline 66 & 0.132 & 0.117 & 0.107 & 0.106 & 0.101 & 0.069 & 0.063 & 0.059 & 0.068 & 0.034 & 0.031 & 0.019 \\
\hline 67 & 0.200 & 0.171 & 0.131 & 0.133 & 0.100 & 0.056 & 0.104 & 0.142 & 0.081 & 0.052 & 0.031 & 0.020 \\
\hline 68 & 0.230 & 0.180 & 0.160 & 0.185 & 0.107 & 0.206 & 0.090 & 0.074 & 0.072 & 0.064 & 0.042 & 0.029 \\
\hline 69 & 0.311 & 0.331 & 0.316 & 0.258 & 0.162 & 0.054 & 0.501 & 0.234 & 0.146 & 0.112 & 0.063 & 0.040 \\
\hline 70 & 0.270 & 0.260 & 0.212 & 0.065 & .nd & .nd & not & .nd & 0.195 & 0.120 & 0.098 & 0.048 \\
\hline 71 & 0.488 & 0.353 & 0.107 & .nd & .nd & 0.411 & .nd & .nd & 0.157 & 0.151 & 0.149 & 0.081 \\
\hline 72 & 0.544 & .nd & .nd & .nd & 0.466 & .nd & .nd & .nd & 0.262 & 0.226 & 0.170 & 0.095 \\
\hline 73 & 0.231 & .nd & .nd & .nd & .nd & .nd & .nd & .nd & 0.435 & 0.204 & 0.224 & 0.225 \\
\hline 74 & .nd & .nd & .nd & .nd & .nd & .nd & .nd & .nd & .nd & .nd & 0.248 & 0.216 \\
\hline 75 & .nd & .nd & .nd & .nd & .nd & .nd & .nd & .nd & .nd & 0.487 & 0.427 & 0.341 \\
\hline 76 & .nd & .nd & .nd & .nd & .nd & .nd & .nd & .nd & .nd & 0.335 & 0.496 & 0.453 \\
\hline 77 & .nd & .nd & .nd & .nd & .nd & nd & .nd & .nd & .nd & .nd & 0.843 & 0.509 \\
\hline 78 & .nd & .nd & .nd & .nd & .nd & .nd & .nd & .nd & .nd & .nd & 0.864 & 0.746 \\
\hline 79 & .nd & .nd & .nd & .nd & .nd & .nd & .nd & .nd & .nd & .nd & .nd & 0.975 \\
\hline 80 & .nd & .nd & .nd & .nd & .nd & .nd & .nd & .nd & .nd & .nd & .nd & .nd \\
\hline 81 & nd & .nd & .nd & .nd & nd & .nd & .nd & .nd & .nd & .nd & .nd & .nd \\
\hline 82 & .nd & .nd & .nd & .nd & .nd & .nd & .nd & .nd & .nd & .nd & .nd & .nd \\
\hline 83 & .nd & .nd & .nd & .nd & .nd & .nd & .nd & .nd & .nd & .nd & .nd & .nd \\
\hline 84 & .nd & .nd & .nd & .nd & .nd & .nd & .nd & .nd & .nd & .nd & .nd & .nd \\
\hline 85 & .nd & .nd & .nd & .nd & .nd & .nd & nd & .nd & .nd & .nd & .nd & .nd \\
\hline 86 & .nd & .nd & .nd & .nd & .nd & .nd & .nd & .nd & .nd & .nd & .nd & .nd \\
\hline 87 & .nd & .nd & .nd & .nd & .nd & .nd & .nd & .nd & .nd & .nd & .nd & .nd \\
\hline 88 & .nd & .nid & .nd & .nd & .nd & .nd & .nd & .nd & .nd & .nd & .nd & .nd \\
\hline 89 & .nd & .nd & .nd & .nd & .nd & .nd & .nd & .nd & .nd & .nd & .nd & .nd \\
\hline
\end{tabular}

.nd = no data available 
Table C2 cont'd: Central Air Conditioner Raw TIme-Temperature Matrix Mean Load in KWh for CEC Region 2

\begin{tabular}{|c|c|c|c|c|c|c|c|c|c|c|c|c|}
\hline \multicolumn{2}{|c|}{ hour $\rightarrow 13$} & 14 & 15 & 16 & 17 & 18 & 19 & 20 & 21 & 22 & 23 & 24 \\
\hline 45 & 0.097 & 0.096 & 0.093 & 0.102 & 0.089 & 0.090 & 0.082 & 0.085 & 0.085 & 0.071 & 0.049 & 0.04 \\
\hline 46 & $0 . c$ & 0.076 & 0.096 & 0.080 & 0.082 & 0.092 & 0.069 & 0.084 & & 0.0 & 0.044 & \\
\hline 47 & 0.085 & 0.065 & 0.057 & 0.070 & 0.080 & 0.077 & 0.082 & 0.070 & 0.062 & 0.060 & 0.049 & 0.041 \\
\hline 48 & 0.078 & 0.087 & 0.073 & 0.068 & 0.080 & 0.062 & 0.071 & 0.073 & 0.060 & 0.052 & 0.041 & 0.031 \\
\hline 49 & 0.066 & 0.071 & 0.075 & 0.079 & 0.067 & 0.073 & 0.062 & 0.058 & 0.054 & 0.056 & 0.046 & 0.035 \\
\hline 50 & 0.076 & 0.058 & 0.071 & 0.067 & 0.066 & 0.065 & 0.062 & 0.057 & 0.060 & 0.047 & 0.043 & 0.030 \\
\hline 51 & 0.061 & 0.067 & 0.067 & 0.058 & C.066 & 0.065 & 0.065 & 0.054 & 0.055 & 0.053 & 0.037 & 0.028 \\
\hline 52 & 0.065 & 0.060 & 0.056 & 0.051 & 0.061 & 0.059 & 0.058 & 0.052 & 0.057 & 0.044 & 0.039 & 0.022 \\
\hline 53 & 0.058 & 0.052 & 0.047 & 0.056 & 0.052 & 0.060 & 0.052 & 0.053 & 0.052 & 0.050 & 0.033 & 0.029 \\
\hline 54 & 0.052 & 0.057 & 0.048 & 0.045 & 0.052 & 0.052 & 0.056 & 0.053 & 0.043 & 0.035 & 0.028 & 0.023 \\
\hline 55 & 0.056 & 0.053 & 0.052 & 0.046 & 0.048 & 0.050 & 0.050 & 0.045 & 0.040 & 0.035 & 0.027 & 0.020 \\
\hline 56 & 0.043 & 0.045 & 0.051 & 0.041 & 0.042 & 0.050 & 0.051 & 0.041 & 0.038 & 0.030 & 0.025 & 0.019 \\
\hline 57 & 0.039 & 0.038 & 0.037 & 0.040 & 0.041 & 0.048 & 0.043 & 0.037 & 0.032 & 0.027 & 0.021 & 0.019 \\
\hline 58 & 0.052 & 0.037 & 0.033 & 0.037 & 0.041 & 0.041 & 0.035 & 0.030 & 0.027 & 0.021 & 0.023 & 0.017 \\
\hline 59 & 0.036 & 0.044 & 0.032 & 0.032 & 0.035 & 0.047 & 0.036 & 0.029 & 0.035 & 0.026 & 0.021 & 0.025 \\
\hline 60 & 0.033 & 0.035 & 0.047 & 0.058 & 0.050 & 0.033 & 0.045 & 0.037 & 0.025 & 0.032 & 0.031 & 0.023 \\
\hline 61 & 0.035 & 0.025 & 0.026 & 0.027 & 0.027 & 0.032 & 0.027 & 0.0 & 0.0 & 0.026 & 0.032 & 0.038 \\
\hline 62 & 0.024 & 0.025 & 0.025 & 0.026 & 0.027 & 0.027 & 0.0 & 0.0 & 0.0 & 0.045 & 0.0 & 0.038 \\
\hline 63 & 0.021 & 0.027 & 0.028 & 0.020 & 0.023 & 0.034 & 0.03 & 0.0 & 0.0 & 0.0 & $0 . c$ & 0.073 \\
\hline 64 & 0.019 & 0.020 & 0.018 & 0.018 & 0.031 & 0.022 & 0.021 & 0.0 & 0.0 & 0.047 & 0.1 & 0.081 \\
\hline 65 & 0.018 & 0.018 & 0.018 & 0.025 & 0.020 & 0.018 & 0.022 & 0.028 & 0.042 & 0.079 & & \\
\hline 66 & 0.021 & 0.020 & 0.020 & 0.024 & 0.017 & 0.024 & 0.037 & 0.034 & 0.0 & 0.138 & 0.156 & 0.147 \\
\hline 67 & 0.024 & 0.019 & 0.018 & 0.018 & 10.029 & 0.033 & 0.037 & 0.063 & 0.0 & 0.176 & 0.229 & 0.212 \\
\hline 68 & 0.028 & 0.028 & 0.021 & 0.027 & 0.033 & 0.033 & 0.054 & 0.108 & 0.1 & 0.258 & 0.264 & 0.245 \\
\hline 69 & 0.028 & 0.027 & 0.033 & 0.032 & 0.035 & 0.055 & 0.050 & 0.123 & 0.220 & 0.295 & 0.363 & 0.373 \\
\hline 70 & 0.047 & 0.037 & 0.045 & 0.043 & 0.052 & 0.062 & 0.088 & 0.124 & 0.278 & 0.396 & 0.493 & 0.502 \\
\hline 71 & 0.056 & 0.054 & 0.050 & 0.058 & 0.070 & 0.087 & 0.147 & 0.255 & 0.379 & 0.526 & 0.605 & 0.407 \\
\hline 72 & 0.070 & 0.075 & 0.069 & 0.066 & 0.088 & 0.089 & 0.260 & 0.292 & 0.508 & 0.670 & 0.631 & 0.697 \\
\hline 73 & 0.113 & 0.115 & 0.123 & 0.134 & 0.155 & 0.255 & 0.332 & 0.426 & 0.646 & 0.771 & 0.736 & 0.843 \\
\hline 74 & 0.201 & 0.148 & 0.165 & 0.198 & 0.251 & 0.291 & 0.396 & 0.574 & 0.682 & 0.941 & 0.703 & .nd \\
\hline 75 & 0.300 & 0.232 & 0.224 & 0.278 & 0.333 & 0.454 & 0.513 & 0.708 & 0.883 & 0.992 & 1.120 & .nd \\
\hline 76 & 0.396 & 0.323 & 0.380 & 0.325 & 0.445 & 0.539 & 0.674 & 0.835 & 0.978 & 1.308 & 1.643 & 0.452 \\
\hline 77 & 0.498 & 0.496 & 0.427 & 0.506 & 0.625 & 0.745 & 0.982 & 1.013 & 1.240 & 1.391 & .nd & .nd \\
\hline 78 & 0.701 & 0.620 & 0.608 & 0.697 & 0.827 & 0.990 & 1.028 & 1.280 & 1.482 & 1.483 & .nd & .nd \\
\hline 79 & 0.938 & 0.879 & 0.827 & 0.916 & 1.011 & 1.200 & 1.292 & 1.429 & 1.453 & 1.253 & .nd & .nd \\
\hline 80 & 1.148 & 1.062 & 1.114 & 1.077 & 1.269 & 1.355 & 1.605 & 1.768 & 1.706 & .nd & .nd & .nd \\
\hline 81 & 1.246 & 1.275 & 1.257 & 1.421 & 1.534 & 1.681 & 1.821 & 1.796 & 1.680 & .nd & .nd & .nd \\
\hline 82 & 1.663 & 1.777 & 1.601 & 1.586 & 1.622 & 1.921 & 2.102 & 1.915 & 1.965 & .nd & .nd & .nd \\
\hline 83 & .nd & 1.780 & 1.745 & 1.807 & 1.994 & 2.213 & 2.171 & 2.085 & 1.724 & .nd & .nd & .nd \\
\hline 84 & .nd & 2.050 & 2.137 & 2.025 & 2.143 & 2.347 & 2.480 & 2.263 & 2.275 & .nd & .nd & .nd \\
\hline 85 & .nd & .nd & 2.250 & 2.128 & 2.255 & 2.444 & 2.400 & 2.421 & .nd & .nd & .nd & .nd \\
\hline 86 & .nd & .nd & .nd & 2.693 & 2.326 & 2.477 & 2.450 & 2.782 & .nd & .nd & .nd & .nd \\
\hline 87 & .nd & .nd & .nd & 2.383 & 2.654 & 2.630 & 2.679 & 2.150 & .nd & .nd & .nd & .nd \\
\hline 88 & .nd & .nd & .nd & .nd & 2.493 & 2.838 & 2.908 & .nd & .nd & .nd & .nd & .nd \\
\hline 89 & .nd & .nd & .nd & .nd & 3.069 & .nd & .nd & .nd & .nd & .nd & .nd & .nd \\
\hline
\end{tabular}

.nd = no data availablo 
Table C3: Central Air Conditioner Raw TIme-Temperature Matrix Mean Load In KWh for CEC Reglon 3

\begin{tabular}{|c|c|c|c|c|c|c|c|c|c|c|c|c|}
\hline \multicolumn{2}{|c|}{ hour $\rightarrow 1$} & 2 & 3 & 4 & 5 & 6 & 7 & 8 & 9 & 10 & 11 & 12 \\
\hline 45 & 0.043 & 0.043 & 0.048 & .051 & 0.051 & 0.080 & 0.126 & 0.125 & 0.111 & 0.115 & 0.103 & 0.098 \\
\hline 46 & 0.042 & 0.043 & 0.049 & 0.051 & 0.056 & 0.075 & 0.147 & 0.132 & 0.121 & 0.097 & 0.107 & 0.104 \\
\hline 47 & 0.039 & 0.042 & 0.044 & 0.049 & 0.053 & 0.070 & 0.106 & 0.119 & 0.108 & 0.106 & 0.100 & 0.102 \\
\hline 48 & 0.034 & 0.039 & 0.041 & 0.043 & 0.042 & 0.064 & 0.097 & 0.118 & & 0.089 & & \\
\hline 49 & 0.036 & 0.033 & 0.036 & 0.035 & 0.047 & 0.063 & 0.094 & 0.099 & 0.0 & 0.086 & 82 & \\
\hline 50 & 0.031 & 0.036 & 0.029 & 0.039 & 0.044 . & 0.063 & 0.087 & 0.098 & 0.094 & 0.104 & 0.068 & 0.084 \\
\hline 51 & 0.032 & 0.028 & 0.033 & 0.035 & 0.038 & 0.056 & 0.106 & 0.090 & 0.076 & 0.077 & 0.085 & 0.067 \\
\hline 52 & 0.027 & 0.029 & 0.031 & 0.030 & 0.034 & 0.042 & 0.083 & 0.091 & 0.072 & 0.065 & 0.0 & 0.076 \\
\hline 53 & 0.025 & 0.026 & 0.027 & 0.030 & 0.031 & 0.047 & 0.069 & 0.074 & 0.0 & 0.074 & 0.0 & 0.057 \\
\hline 54 & 0.027 & 0.023 & 0.021 & 0.022 & 0.027 & 0.031 & 0.053 & 0.058 & 0.057 & 0.065 & 0.0 & 0.066 \\
\hline 55 & 0.024 & 0.021 & 0.024 & 0.022 & 0.027 & 0.029 & 0.041 & 0.042 & 0.053 & 0.053 & 0.051 & 0.050 \\
\hline 56 & 0.022 & 0.021 & 0.019 & 0.019 & 0.018 & 0.029 & 0.048 & 0.040 & 0.038 & 0.044 & 0.047 & 0.039 \\
\hline 57 & 0.019 & 0.017 & 0.017 & 0.018 & 0.018 & 0.023 & 0.035 & 0.034 & 0.034 & 0.038 & 0.039 & 0.041 \\
\hline 58 & 0.016 & 0.015 & 0.016 & 0.015 & 0.014 & 0.020 & 0.023 & 0.023 & 0.027 & 0.035 & 0.040 & 0.036 \\
\hline 59 & 0.015 & 0.016 & 0.016 & 0.016 & 0.019 & 0.018 & 0.027 & 0.028 & 0.0 & 0.026 & & 0.032 \\
\hline 60 & 0.017 & 0.015 & 0.014 & 0.018 & 0.0 & 0.0 & 0.02 & 0.027 & 0.0 & 0.0 & & 0.028 \\
\hline 61 & 0.014 & 0.015 & 0.019 & 0.016 & 0.0 & 0.016 & 0.0 & 0.019 & & & & 0.0 \\
\hline 62 & 0.016 & 0.021 & 0.0 & 0.018 & 0.0 & 0.0 & 0.0 & 0.0 & & & & \\
\hline 63 & 0.023 & 0.018 & 0.0 & 0.02 & 0.023 & 0.020 & 0.0 & 0.023 & & 0.0 & & 0.021 \\
\hline 64 & 0.018 & 0.021 & 0.026 & 0.029 & 0.020 & 0.023 & 0.024 & 0.029 & & 0.0 & & .022 \\
\hline 65 & 0.027 & 0.026 & 0.036 & 0.032 & 0.031 & 0.034 & 0.033 & 0.034 & & & & .020 \\
\hline 66 & 0.031 & 0.046 & 0.030 & 0.041 & 0.040 & 0.041 & 0.042 & 0.047 & & 25 & & .019 \\
\hline 67 & 0.060 & 0.058 & 0.067 & 0.061 & 0.053 & 0.053 & 0.049 & 0.057 & & 0.036 & & .020 \\
\hline 68 & 0.067 & 0.082 & 0.076 & 0.079 & 0.081 & 0.055 & 0.074 & 0.073 & 0.0 & 0.043 & & 0.023 \\
\hline 69 & 0.104 & 0.106 & 0.093 & 0.092 & 0.087 & 0.091 & 0.088 & 0.098 & 0.069 & 0.051 & 0.036 & 0.031 \\
\hline 70 & 0.149 & 0.126 & 0.125 & 0.132 & 0.129 & 0.113 & 0.103 & 0.117 & 0.137 & 0.062 & 0.061 & 0.034 \\
\hline 71 & 0.164 & 0.172 & 0.165 & 0.168 & 0.142 & 0.134 & 0.145 & 0.146 & 0.127 & 0.081 & 0.071 & 0.052 \\
\hline 72 & 0.223 & 0.230 & 0.236 & 0.226 & 0.181 & 0.182 & 0.167 & 0.189 & 0.181 & 0.144 & 0.092 & 0.092 \\
\hline 73 & 0.301 & 0.297 & 0.274 & 0.248 & 0.221 & 0.232 & 0.225 & 0.238 & 0.194 & 0.171 & 0.110 & 0.119 \\
\hline 74 & 0.366 & 0.370 & 0.340 & 0.339 & 0.283 & 0.228 & 0.144 & 0.288 & 0.360 & 0.249 & 0.179 & 0.146 \\
\hline 75 & 0.443 & 0.425 & 0.404 & 0.342 & 0.343 & .nd & .nd & .nd & 0.355 & 0.288 & 0.256 & 0.204 \\
\hline 76 & 0.540 & 0.500 & 0.335 & 0.331 & .nd & .nd & .nd & .nd & 0.514 & 0.367 & 0.351 & 0.292 \\
\hline 77 & 0.675 & 0.527 & 0.567 & .nd & .nd & .nd & .nd & .nd & 0.528 & 0.579 & 0.436 & 0.413 \\
\hline 78 & 0.783 & 0.784 & .nd & .nd & .no & .no & .nd & .nd & .nd & 0.681 & 0.494 & 0.562 \\
\hline 79 & 0.937 & 0.730 & .nd & .nd & .nd & .nd & .nd & .nd & .nd & 0.712 & 0.723 & 0.675 \\
\hline 80 & .nd & .nd & .nd & .nd & .nd & .nd & .nd & .nd & .nd & .nd & 0.961 & 0.851 \\
\hline 81 &.$n d$ & .nd & .nd & .nd & .nd & .nd & .nd & .nd & .nd & .nd & .nd & 1.106 \\
\hline 82 & .nd & .nd & .nd & .nd & .nd & .nd & .nd & .nd & .nd & .nd & .nd & 1.091 \\
\hline 83 & .nd & .nd & .nd & .nd & .nd & .nd & .nd & .nd & .nd & .nd & .nd & 1.342 \\
\hline 84 & .nd & .nd & .nd & .nd & .nd & .nd & .nd & .nd & .nd & .nd & .nd & .nd \\
\hline 85 & .nd & .nd & .nd & .nd & .nd & .nd & .nd & .nd & .nd & .nd & .nd & .nd \\
\hline 86 & .nd & .nd & .nd & .nd & .nd & .nd & .nd & .nd & .nd & .nd & .nd & .nd \\
\hline 87 & .nd & .nd & .nd & .nd & .nd & .nd & .nd & .nd & .nd & .nd & .nd & .nd \\
\hline 88 & .nd & .nd & .nd & .nd & .nd & .nd & .nd & .nd & .nd & .nd & .nd & .nd \\
\hline 89 & & .nd & 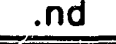 & .nd & .nd & .10 & .nd & .nd & .nd & .nd & .nd & .nd \\
\hline
\end{tabular}

.nd = no data avaiable 


\begin{tabular}{|c|c|c|c|c|c|c|c|c|c|c|c|c|}
\hline & & & $M e$ & ral & Ir & S & C & & & & & \\
\hline \multicolumn{2}{|c|}{ hour $\rightarrow 13$} & 14 & 15 & 16 & 17 & 18 & 19 & 20 & 21 & 22 & 23 & 24 \\
\hline 45 & 0.100 & 0.080 & 0.101 & 0.077 & 0.109 & 0.112 & 0.104 & 0.113 & 0.101 & 0.081 & 0.067 & 0.048 \\
\hline 46 & 0.086 & 0.086 & 0.089 & 0.098 & 0.081 & 0.081 & .100 & 0.086 & 0.089 & 0.073 & .058 & .048 \\
\hline 47 & 0.096 & 0.083 & 0.074 & 0.083 & 0.088 & 0.117 & 0.104 & 0.086 & 0.072 & 0.069 & 0.054 & 0.042 \\
\hline 48 & 0.078 & 0.088 & 0.087 & 0.082 & 0.110 & 0.090 & 0.095 & 0.090 & 0.073 & 0.071 & 0.057 & 0.042 \\
\hline 49 & 0.079 & 0.070 & 0.082 & 0.095 & 0.086 & 0.089 & 0.081 & 0.077 & 0.075 & 0.061 & 0.054 & 0.040 \\
\hline 50 & 0.062 & 0.071 & 0.080 & 0.071 & 0.077 & 0.083 & 0.079 & 0.071 & 0.072 & 0.062 & 0.054 & 0.037 \\
\hline 51 & 0.076 & 0.070 & 0.062 & 0.076 & 0.082 & 0.081 & 0.086 & 0.071 & 0.064 & 0.062 & 0.049 & 0.035 \\
\hline 52 & 0.061 & 0.075 & 0.065 & 0.062 & 0.070 & 0.075 & 0.075 & 0.066 & 0.065 & 0.060 & 0.043 & 135 \\
\hline 53 & 0.062 & 0.057 & 0.063 & 0.061 & 0.065 & 0.0 & 0.0 & 0.0 & $0 . c$ & & 0.039 & .028 \\
\hline 54 & 0.059 & 0.05 & 0.049 & 0.0 & 0.058 & 0.071 & 0.068 & 0.058 & 0.058 & 0.045 & 0.037 & 0.026 \\
\hline 55 & 0.051 & 0.051 & 0.053 & 0.049 & 0.059 & 0.062 & 0.057 & 0.060 & 0.056 & 0.041 & 0.032 & 0.027 \\
\hline 56 & 0.043 & 0.048 & 0.046 & 0.055 & 0.056 & 0.059 & 0.062 & 0.050 & 0.045 & 0.035 & 0.029 & 0.025 \\
\hline 57 & 0.041 & 0.037 & 0.040 & 0.045 & 0.047 & 0.058 & 0.048 & 0.047 & 0.0 & 0.033 & 0.030 & 0.021 \\
\hline 58 & 0.038 & 0.037 & 0.041 & 0.035 & 0.054 & 0.0 & 0.046 & 0.0 & & & & .020 \\
\hline 59 & 0.03 & 0.0 & 0.03 & 0.0 & 0.0 & 0.0 & & & & 0.0 & 25 & 018 \\
\hline 60 & 0.02 & 0.032 & 0.028 & 0.03 & 0.0 & 0.0 & & & & 0.029 & 0.017 & \\
\hline 61 & 0.028 & 0.030 & 0.031 & 0.028 & 0.033 & 0.0 & & 0.028 & & 0.021 & 0.022 & \\
\hline 62 & 0.025 & 0.023 & 0.025 & 0.0 & 0.030 & 0.034 & & 0.025 & 0.026 & 0.023 & 0.017 & 0.014 \\
\hline 63 & 0.020 & 0.021 & 0.026 & 0.026 & 0.028 & 0.032 & 0.022 & 0.023 & 0.018 & 0.017 & 0.017 & 0.019 \\
\hline 64 & 0.022 & 0.022 & 0.017 & 0.021 & 0.025 & 0.023 & 0.022 & 0.020 & 0.024 & 0.018 & 0.015 & 0.019 \\
\hline 65 & 0.019 & 0.018 & 0.019 & 0.020 & 0.022 & 0.018 & 0.018 & 0.019 & 0.020 & 0.020 & 0.023 & 0.025 \\
\hline 66 & 0.014 & 0.01 & 0.017 & 0.017 & 0.018 & 0.0 & 0.0 & 0.0 & 0.1 & 0.0 & & 31 \\
\hline 67 & 0.0 & & & 0.0 & 0.0 & & & & & & & \\
\hline 68 & & & 0.020 & 0.0 & 0.021 & 0.022 & 24 & & 0. & & & \\
\hline 69 & 0.020 & 0.020 & 0.018 & 0.018 & 0.021 & 0.02 & 0.020 & 0.033 & 0.0 & 79 & 0.083 & 0.097 \\
\hline 70 & 0.034 & 0.023 & 0.020 & 0.024 & 0.023 & 0.032 & 0.038 & 0.045 & 0.098 & 0.134 & 0.142 & 0.142 \\
\hline 71 & 0.046 & 0.029 & 0.029 & 0.032 & 0.035 & 0.036 & 0.057 & 0.081 & 0.115 & 0.173 & 0.184 & 0.202 \\
\hline 72 & 0.061 & 0.051 & 0.042 & 0.041 & 0.042 & 0.066 & 0.064 & 0.092 & 0.176 & 0.234 & 0.288 & 0.221 \\
\hline 73 & 0.078 & 0.078 & 0.058 & 0.058 & 0.075 & 0.090 & 0.114 & 0.166 & 0.264 & 0.370 & 0.342 & 0.311 \\
\hline 74 & 0.133 & 0.094 & 0.107 & 0.096 & 0.084 & 0.112 & 0.164 & 0.250 & 0.376 & 0.497 & 0.437 & 0.406 \\
\hline 75 & 0.188 & 0.164 & 0.133 & 0.160 & 0.207 & 0.240 & 0.255 & 0.386 & 0.487 & 0.566 & 0.554 & 0.467 \\
\hline 76 & 0.256 & 0.247 & 0.236 & 0.224 & 0.244 & 0.319 & 0.433 & 0.518 & 0.587 & 0.791 & 0.722 & 0.612 \\
\hline 77 & 0.368 & 0.311 & 0.395 & 0.348 & 0.381 & 0.438 & 0.595 & 0.653 & 0.876 & 0.982 & 0.879 & 0.711 \\
\hline 78 & & & & & 0. & 0.671 & 0.764 & 0.8 & & 1.1 & 1.073 & 0.816 \\
\hline $7 \mathrm{~s}$ & & & & & & & & & & & & \\
\hline 80 & 0.84 & 0.772 & 0.8 & 0.883 & 0.96 & 1.0 & 1.2 & 1.3 & 1.420 & 1.602 & 1.399 & 1.124 \\
\hline 81 & 1.010 & 1.041 & 0.928 & 1.082 & 1.228 & 1.398 & 1.529 & 1.582 & 1.738 & 1.8 & 1.716 & .nd \\
\hline 82 & 1.298 & 1.231 & 1.275 & 1.323 & 1.421 & 1.582 & 1.750 & 1.816 & 1.976 & 2.028 & 1.686 & .nd \\
\hline 83 & 1.454 & 1.441 & 1.564 & 1.546 & 1.688 & 1.826 & 2.036 & 2.079 & 2.119 & 2.226 & .nd & .nd \\
\hline 84 & 1.741 & 1.761 & 1.731 & 1.885 & 1.926 & 2.140 & 2.329 & 2.369 & 2.460 & .nd & .nd & .nd \\
\hline 85 & 1.821 & 1.925 & 2.008 & 2.116 & 2.259 & 2.433 & 2.614 & 2.538 & 2.623 & .nd & .nd & .nd \\
\hline 86 & .nd & 2.210 & 2.357 & 2.538 & 2.528 & 2.704 & 2.838 & 2.922 & .nd & .nd & .nd & .nd \\
\hline 87 & .nd & .nd & .nd & 2.638 & 2.870 & 2.985 & 3.076 & 3.026 & .nd & .nd & .nd & .nd \\
\hline 88 & .nd & .nd & .nd & 2.530 & 2.841 & 3.058 & .nd & .nd & .nd & .nd & .nd & .nd \\
\hline 89 & .nd & .nd & .nd & .nd & .nd & 3.133 & 0.2007 & .nd & .nd & .nd & .nd & .nd \\
\hline
\end{tabular}

.nd = no data available 


\begin{tabular}{|c|c|c|c|c|c|c|c|c|c|c|c|c|}
\hline \multirow{2}{*}{\multicolumn{2}{|c|}{ hour $\rightarrow 1$}} & \multirow{2}{*}{$\begin{array}{l}\text { e C4: } \\
2\end{array}$} & \multirow{2}{*}{$\begin{array}{l}\text { Central } \\
\text { Mear } \\
3\end{array}$} & \multirow{2}{*}{$\begin{array}{l}\text { Air } \\
4 \\
4 \text { Loa }\end{array}$} & \multirow{2}{*}{$\begin{array}{l}\text { Cond } \\
\text { d in } \\
5\end{array}$} & \multirow{2}{*}{$\begin{array}{c}\text { ditioner } \\
\text { kWh } \\
6\end{array}$} & \multirow{2}{*}{$\begin{array}{c}\text { Raw } \\
\text { for CEC } \\
7\end{array}$} & \multicolumn{3}{|c|}{$\begin{array}{l}\text { Time-Temperature } \\
\text { Region } 4\end{array}$} & \multicolumn{2}{|l|}{ Matrix } \\
\hline & & & & & & & & 8 & 9 & 10 & 11 & 12 \\
\hline 45 & 0.047 & 0.046 & 0.046 & 0.049 & 0.051 & 0.053 & 0.054 & 0.062 & 0.054 & 0.052 & 0.043 & 0.039 \\
\hline 46 & 0.042 & 0.042 & 0.045 & 0.046 & 0.046 & 0.048 & 0.048 & 0.066 & 0.052 & 0.047 & 0.046 & 0.039 \\
\hline 47 & 0.045 & 0.045 & 0.043 & 0.043 & 0.043 & 0.044 & 0.045 & 0.051 & 0.052 & 0.050 & 0.052 & 0.042 \\
\hline 48 & 0.039 & 0.040 & 0.038 & 0.042 & 0.043 & 0.043 & 0.046 & 0.048 & 0.044 & 0.043 & 0.052 & 0.045 \\
\hline 49 & 0.040 & 0.038 & 0.040 & 0.039 & 0.042 & 0.041 & 0.043 & 0.050 & 0.045 & 0.041 & 0.041 & 0.044 \\
\hline 50 & 0.036 & 0.037 & 0.037 & 0.040 & 0.038 & 0.038 & 0.038 & 0.040 & 0.040 & 0.044 & 0.043 & 0.048 \\
\hline 51 & 0.037 & 0.036 & 0.036 & 0.034 & 0.034 & 0.036 & 0.037 & 0.042 & 0.038 & 0.040 & 0.039 & 0.041 \\
\hline 52 & 0.034 & 0.032 & 0.031 & 0.032 & 0.033 & 0.035 & 0.038 & 0.040 & 0.037 & 0.037 & 0.040 & 0.036 \\
\hline 53 & 0.030 & 0.030 & 0.029 & 0.030 & 0.031 & 0.032 & 0.034 & 0.037 & 0.035 & 0.036 & 0.037 & 0.031 \\
\hline 54 & 0.028 & 0.027 & 0.028 & 0.027 & 0.027 & 0.030 & 0.030 & 0.034 & 0.033 & 0.034 & 0.034 & 0.033 \\
\hline 55 & 0.027 & 0.027 & 0.026 & 0.027 & 0.028 & 0.027 & 0.028 & 0.037 & 0.030 & 0.031 & 0.029 & 0.032 \\
\hline 56 & 0.026 & 0.024 & 0.024 & 0.024 & 0.024 & 0.023 & 0.029 & 0.036 & 0.035 & 0.025 & 0.028 & 0.027 \\
\hline 57 & 0.021 & 0.023 & 0.022 & 0.022 & 0.025 & 0.027 & 0.026 & 0.027 & 0.025 & 0.026 & 0.029 & 0.026 \\
\hline 58 & 0.022 & 0.024 & 0.027 & 0.029 & 0.021 & 0.022 & 0.023 & 0.027 & 0.022 & 0.026 & 0.020 & 0.022 \\
\hline 59 & 0.025 & 0.029 & 0.025 & 0.022 & 0.025 & 0.025 & 0.026 & 0.025 & 0.028 & 0.027 & 0.022 & 0.022 \\
\hline 60 & 0.033 & 0.026 & 0.024 & 0.027 & 0.021 & 0.021 & 0.025 & 0.028 & 0.026 & 0.025 & 0.025 & 0.022 \\
\hline 61 & 0.034 & 0.028 & 0.026 & 0.022 & 0.028 & 0.030 & 0.029 & 0.031 & 0.028 & 0.028 & 0.024 & 0.023 \\
\hline 62 & 0.033 & 0.032 & 0.030 & 0.037 & 0.025 & 0.026 & 0.027 & 0.031 & 0.030 & 0.025 & 0.028 & 0.025 \\
\hline 63 & 0.042 & 0.049 & 0.043 & 0.034 & 0.032 & 0.029 & 0.031 & 0.033 & 0.035 & 0.026 & 0.024 & 0.021 \\
\hline 64 & 0.060 & 0.053 & 0.045 & 0.042 & 0.041 & 0.033 & 0.026 & 0.034 & 0.041 & 0.044 & 0.025 & 0.020 \\
\hline 65 & 0.097 & 0.062 & 0.054 & 0.045 & 0.032 & 0.031 & 0.046 & 0.053 & 0.060 & 0.052 & 0.037 & 0.026 \\
\hline 66 & 0.095 & 0.074 & 0.054 & 0.038 & 0.077 & 0.076 & 0.057 & 0.084 & 0.049 & 0.073 & 0.059 & 0.031 \\
\hline 67 & 0.162 & 0.099 & 0.095 & 0.124 & 0.105 & 0.091 & 0.270 & 0.104 & 0.087 & 0.092 & 0.070 & 0.053 \\
\hline 68 & 0.177 & 0.113 & 0.154 & 0.013 & .nd & 0.281 & .nd & 0.184 & 0.149 & 0.148 & 0.120 & 0.082 \\
\hline 69 & 0.335 & 0.475 & 0.519 & 0.496 & 0.302 & .nd & .nd & 0.326 & 0.180 & 0.191 & 0.160 & 0.113 \\
\hline 70 & 0.198 & .nd & .nd & .nd & .nd & .nd & .nd & 0.311 & 0.337 & 0.170 & 0.244 & 0.175 \\
\hline 71 & 0.666 & nd & .nd & .nd & .nd & .nd & .nd & nd & 0.383 & 0.192 & 0.250 & 0.239 \\
\hline 72 & 0.928 & .nd & .nd & nd & .nd & .nd & .nd & .nd & .nd & 0.454 & 0.235 & 0.378 \\
\hline 73 & .nd & nd & .nd & .nd & .nd & .nd & .nd & .nd & .nd & 0.639 & 0.456 & 0.329 \\
\hline 74 & .nd & .nd & .nd & .nd & .nd & .nd & .nd & .nd & 0.561 & 0.470 & 0.504 & 0.461 \\
\hline 75 & .nd & .nd & .nd & nd & .nd & .nd & .nd & .nd & .nd & 0.788 & 0.919 & 0.367 \\
\hline 76 & .nd & .nd & .nd & .nd & .nd & .nd & .nd & .nd & .nd & .nd & .nd & 0.575 \\
\hline 77 & .nd & .nd & .nd & .nd & .nd & .nd & .nd & .nd & .nd & .nd & 0.559 & 1.126 \\
\hline 78 & .nd & .nd & .nd & .nd & .nd & .nd & .nd & .nd & .nd & .nd & 1.255 & 1.596 \\
\hline 79 & .nd & nd & .nd & .nd & .nd & .nd & .nd & .nd & .nd & .nd & .nd & .nd \\
\hline 80 & .nd & .nd & .nd & .nd & .nd & .nd & .nd & .nd & .nd & .nd & .nd & .nd \\
\hline 81 & .nd & .nd & .nd & .nd & .nd & .nd & .nd & .nd & .nd & .nd & .nd & .nd \\
\hline 82 & .nd & .nd & .nd & .nd & .nd & .nd & .nd & .nd & .nd & .nd & .nd & .nd \\
\hline 83 & .nd & .nd & nd & .nd & .nd & .nd & .nd & .nd & .nd & .nd & .nd & .nd \\
\hline 85 & .nd & .nd & .nd & .nd & .nd & .nd & .nd & .nd & .nd & .nd & .nd & .nd \\
\hline 86 & .nd & .nd & .nd & .nd & .nd & .nd & .nd & .nd & .nd & .nd & .nd & .nd \\
\hline 87 & .nd & .nd & .nd & .nd & .nd & .nd & .nd & .nd & .nd & .nd & .nd & .nd \\
\hline 88 & .nd & .nd & .nd & .nd & .nd & .nd & .nd & .nd & .nd & .nd & .nd & .nd \\
\hline 89 & .nd & .nd & .nd & .nd & .nd & .nd & .nd & .nd & .nd & .nd & .nd & .nd \\
\hline
\end{tabular}

.nd = no data avaitable 


\begin{tabular}{|c|c|c|c|c|c|c|c|c|c|c|c|c|}
\hline & rable & & & Loa & $\begin{array}{l}\text { Air } \\
\text { d }\end{array}$ & Wh & & & $n$ & & & \\
\hline \multicolumn{2}{|r|}{$r \rightarrow 13$} & 14 & 15 & 16 & 17 & 18 & 19 & 20 & 21 & 22 & 23 & 24 \\
\hline 45 & .nd & 0.025 & .nd & .nd & .nd & .nd & .nd & .nd & 0.045 & 0.049 & 0.046 & 0.051 \\
\hline 46 & .nd & 0.035 & .nd & .nd & .nd & .nd & 0.047 & 0.049 & 0.048 & 0.050 & 0.057 & 0.050 \\
\hline 47 & 0.030 & 0.020 & 0.026 & 0.025 & 0.024 & 0.041 & 0.040 & 0.048 & 0.051 & 0.065 & 0.052 & 0.048 \\
\hline 48 & 0.040 & .nd & .nd & 0.029 & 0.027 & 0.039 & 0.032 & 0.052 & 0.052 & 0.047 & 0.048 & 0.045 \\
\hline 49 & 0.044 & 0.036 & 0.033 & 0.024 & 0.027 & 0.038 & 0.050 & 0.050 & 0.051 & 0.045 & 0.046 & 0.041 \\
\hline 50 & 0.040 & 0.041 & 0.040 & 0.031 & 0.043 & 0.045 & 0.054 & 0.053 & 0.045 & 0.045 & 0.042 & 0.039 \\
\hline 51 & 0.038 & 0.041 & 0.039 & 0.040 & 0.041 & 0.050 & 0.044 & 0.045 & 0.044 & 0.041 & 0.040 & 0.038 \\
\hline 52 & 0.043 & 0.032 & 0.034 & 0.037 & 0.044 & 0.048 & 0.041 & 0.041 & 0.040 & 0.040 & 0.039 & 0.036 \\
\hline 53 & 0.038 & 0.043 & 0.035 & 0.036 & 0.039 & 0.046 & 0.040 & 0.039 & 0.038 & 0.0 & 0.037 & 0.034 \\
\hline 54 & 0.030 & 0.030 & 0.032 & 0.033 & 0.041 & 0.043 & 0.037 & 0.038 & 0.0 & 0.0 & 0.032 & 0.031 \\
\hline 55 & 0.033 & 0.031 & 0.032 & 0.035 & 0.038 & 0.035 & 0.036 & 0.034 & 0.0 & & 0.0 & 0.028 \\
\hline 56 & 0.028 & 0.032 & 0.028 & 0.031 & 0.029 & 0.035 & 0.0 & 0.0 & & & & 0.027 \\
\hline 57 & 0.024 & 0.026 & 0.028 & 0.027 & 0.029 & 0.033 & 0.030 & 0.029 & 0.0 & & 0.0 & 0.024 \\
\hline 58 & 0.023 & 0.023 & 0.026 & 0.024 & 0.028 & 0.029 & 0.028 & 0.026 & & & 0.0 & 0.023 \\
\hline 59 & 0.021 & 0.020 & 0.020 & 0.025 & 0.025 & 0.027 & 0.026 & 0.024 & 0.0 & & 0.030 & 0.029 \\
\hline 60 & 0.020 & 0.019 & 0.021 & 0.021 & 0.023 & 0.027 & 0.023 & 0.021 & 0.025 & 0.028 & 0.024 & 0.024 \\
\hline 61 & 0.020 & 0.019 & 0.021 & 0.021 & 0.022 & 0.024 & 0.023 & 0.022 & 0.027 & 0.042 & 0.038 & 0.036 \\
\hline 62 & 0.018 & 0.022 & 0.019 & 0.018 & 0.018 & 0.023 & 0.025 & 0.025 & 0.033 & 0.040 & 0.048 & 0.041 \\
\hline 63 & 0.020 & 0.018 & 0.020 & 0.020 & 0.021 & 0.022 & 0.026 & 0.036 & 0.052 & 0.062 & 0.061 & 0.048 \\
\hline 64 & 0.020 & 0.018 & 0.021 & 0.019 & 0.024 & 0.025 & 0.034 & 0.046 & 0.061 & 0.084 & 0.076 & 0.071 \\
\hline 65 & 0.024 & 0.022 & 0.019 & 0.025 & 0.024 & 0.036 & 0.038 & 0.082 & 0.097 & 0.120 & 0.125 & 0.119 \\
\hline 66 & 0.021 & 0.024 & 0.025 & 0.028 & 0.037 & 0.042 & 0.106 & 0.099 & 0.104 & 0.194 & 0.180 & 0.157 \\
\hline 67 & 0.040 & 0.028 & 0.033 & 0.037 & 0.066 & 0.078 & 0.109 & 0.148 & 0.208 & 0.277 & 0.283 & 0.178 \\
\hline 68 & 0.057 & 0.062 & 0.064 & 0.080 & 0.083 & 0.117 & 0.178 & 0.224 & 0.295 & 0.317 & 0.291 & 0.275 \\
\hline 69 & 0.078 & 0.055 & 0.071 & 0.079 & 0.106 & 0.169 & 0.259 & 0.318 & 0.408 & 0.549 & 0.425 & 0.325 \\
\hline 70 & 0.126 & 0.109 & 0.089 & 0.107 & 0.161 & 0.268 & 0.278 & 0.419 & 0.577 & 0.477 & 0.830 & 0.491 \\
\hline 71 & 0.187 & 0.141 & 0.154 & 0.187 & 0.259 & 0.377 & 0.530 & 0.575 & 0.745 & 0.801 & 0.661 & 0.604 \\
\hline 72 & 0.218 & 0.207 & 0.248 & 0.258 & 0.404 & 0.532 & 0.618 & 0.814 & 0.836 & 1.243 & 0.525 & .nd \\
\hline 73 & 0.354 & 0.329 & 0.318 & 0.410 & 0.526 & 0.592 & 0.755 & 1.073 & 1.094 & 1.011 & .nd & 1.187 \\
\hline 74 & 0.502 & 0.343 & 0.396 & 0.499 & 0.683 & 0.898 & 1.053 & 1.194 & 1.082 & .nd & 1.743 & .nd \\
\hline 75 & 0.576 & 0.561 & 0.525 & 0.663 & 0.779 & 0.958 & 1.287 & 1.288 & 1.672 & .nd & .nd & .nd \\
\hline 76 & 0.404 & 0.807 & 0.671 & 0.780 & 1.107 & 1.349 & 1.345 & 1.309 & 1.250 & 2.063 & .nd & .nd \\
\hline 77 & 0.806 & 0.872 & 1.066 & 1.008 & 1.052 & 1.256 & 1.496 & 1.728 & .nd & .nd & .nd & .nd \\
\hline 78 & 0.840 & 0.877 & 0.989 & 1.072 & 1.279 & 1.481 & 1.847 & 2.055 & 2.572 & .nd & .nd & .nd \\
\hline 79 & 1.822 & 0.962 & 1.298 & 1.400 & 1.330 & 1.673 & 1.999 & 1.567 & .nd & .nd & .nd & .nd \\
\hline 80 & .nd & 1.344 & 1.113 & 1.522 & 2.052 & 1.901 & 1.832 & .nd & . nd & .nd & .nd & .nd \\
\hline 81 & 2.099 & .nd & 1.488 & 2.296 & 1.906 & 2.445 & 1.785 & 2.967 & .nd & .nd & .nd & .nd \\
\hline 82 & .nd & .nd & .nd & 1.362 & 1.704 & 1.911 & .nd & .nd & .nd & .nd & .nd & .nd \\
\hline 83 & .nd & 2.644 & .nd & 1.778 & nd & .nd & 3.177 & .nd & .nd & .nd & .nd & .nd \\
\hline 85 & .nd & .nd & 2.811 & .nd & .nd & 3.118 & .nd & .nd & .nd & .nd & .nd & .nd \\
\hline 86 & .nd & .nd & .nd & 2.976 & 3.050 & .nd & .nd & .nd & .nd & .nd & .nd & .nd \\
\hline 87 & .nd & .nd & .nd & .nd & .nd & .nd & .nd & .nd & .nd & .nd & .nd & .nd \\
\hline 88 & .nd & .nd & .nd & .nd & .nd & .nd & .nd & .nd & .nd & .nd & .nd & .nd \\
\hline 89 & id & nd & .nd & .nd & .nd & .nd & .nd & .nd & .nd & .nd & .nd & .nd \\
\hline
\end{tabular}

.nd = no data available 


\begin{tabular}{|c|c|c|c|c|c|c|c|c|c|c|c|c|}
\hline \multirow[b]{2}{*}{ hour - } & \multirow[b]{2}{*}{1} & \multirow{2}{*}{$\begin{array}{r}\text { Table } \\
2 \\
2\end{array}$} & \multicolumn{2}{|c|}{$\begin{array}{l}\text { C5: Central Al } \\
\text { Number of }\end{array}$} & \multicolumn{2}{|c|}{$\begin{array}{l}\text { Conditioner } \\
\text { Observations }\end{array}$} & \multirow{2}{*}{$\begin{array}{c}\text { Raw } \\
\text { for all } \\
7\end{array}$} & \multicolumn{2}{|c|}{$\begin{array}{l}\text { Ime-Temperature } \\
\text { CEC Regions }\end{array}$} & \multicolumn{2}{|c|}{ Matrix } & \multirow[b]{2}{*}{12} \\
\hline & & & 3 & 4 & 5 & 6 & & 8 & 9 & 10 & 11 & \\
\hline 45 & 12172 & 13295 & 13543 & 14843 & 13905 & 14703 & 16538 & 15577 & 14516 & 8920 & 6179 & 4557 \\
\hline 46 & $8 C 04$ & 8718 & 8847 & 10075 & 10317 & 9848 & 10167 & 10669 & 9512 & 8182 & 3881 & 3341 \\
\hline 47 & 13402 & 15058 & 14193 & 13370 & 17839 & 18592 & 20795 & 19134 & 13121 & 11135 & 6690 & 4176 \\
\hline 48 & 10804 & 9114 & 11231 & 12092 & 12532 & 13214 & 12497 & 11571 & 11251 & 6944 & 6279 & 2954 \\
\hline 49 & 16101 & 18166 & 20649 & 21490 & 18004 & 19931 & 22971 & 20909 & 16291 & 16036 & 10983 & 7214 \\
\hline 50 & 12912 & 14741 & 13349 & 14713 & 15465 & 17758 & 15740 & 15488 & 13579 & 11023 & 7832 & 6196 \\
\hline 51 & 20939 & 19612 & 22374 & 23095 & 24017 & 26221 & 22500 & 24925 & 16828 & 15558 & 15044 & 11087 \\
\hline 52 & 12483 & 15633 & 16716 & 17034 & 18232 & 17133 & 21267 & 15562 & 14039 & 12379 & 10859 & 10057 \\
\hline 53 & 27179 & 27265 & 27391 & 29272 & 29826 & 29933 & 29016 & 29152 & 25223 & 19921 & 18505 & 16722 \\
\hline 54 & 17139 & 18688 & 18982 & 21473 & 20369 & 21247 & 21616 & 19222 & 18569 & 13576 & 12982 & 9847 \\
\hline 55 & 27088 & 29321 & 32123 & 29344 & 30041 & 31449 & 34122 & 33461 & 30961 & 24084 & 21202 & 19261 \\
\hline 56 & 21683 & 21986 & 21398 & 22434 & 23337 & 26111 & 25701 & 24762 & 20548 & 19615 & 16840 & 13493 \\
\hline 57 & 30404 & 33252 & 34293 & 35827 & 38637 & 36674 & 38804 & 40071 & 37010 & 31103 & 22875 & 24430 \\
\hline 58 & 22844 & 22781 & 22447 & 21785 & 24856 & 24072 & $2: 497$ & 30675 & 24804 & 19826 & 17046 & 13754 \\
\hline 59 & 31974 & 33369 & 33745 & 37093 & 36969 & 41700 & 4153 & 35881 & 39929 & 36864 & 30211 & 27102 \\
\hline 60 & 21844 & 23300 & 25147 & 27223 & 28145 & 28090 & 2300 & 30006 & 27339 & 27028 & 23011 & 17792 \\
\hline 61 & 40589 & 37038 & 38238 & 38214 & 36770 & 36520 & $3 / 593$ & 36475 & 42620 & 40707 & 39596 & 32957 \\
\hline 62 & 25840 & 24652 & 24088 & 24186 & 25792 & 23697 & 23121 & 23405 & 27525 & 27176 & 22423 & 19116 \\
\hline 63 & 37330 & 36884 & 36506 & 35505 & 34738 & 32412 & 31175 & 32316 & 36188 & 43539 & 42648 & 36117 \\
\hline 64 & 23584 & 21600 & 21410 & 20446 & 15880 & 15655 & 14131 & 15240 & 19950 & 25977 & 24103 & 24364 \\
\hline 65 & 26559 & 27796 & 23666 & 22710 & 20727 & 20593 & 15783 & 16265 & 22916 & 34297 & 38268 & 34692 \\
\hline 66 & 12657 & 12746 & 13333 & 10337 & 11369 & 8117 & 7583 & 9767 & 11880 & 16098 & 22770 & 26376 \\
\hline 67 & 17078 & 15922 & 13042 & 15950 & 13180 & 7870 & 6244 & 8149 & 16212 & 22968 & 33698 & 35323 \\
\hline 68 & 9726 & 10069 & 9827 & 7087 & 3584 & 4432 & 5009 & 3702 & 8737 & 11850 & 17653 & 18678 \\
\hline 69 & 12224 & 13055 & 11562 & 7236 & 7765 & 8002 & 5289 & 7032 & 8482 & 15587 & 22535 & 33843 \\
\hline 70 & 7449 & 7611 & 4298 & 4727 & 4412 & 2378 & 2488 & 3289 & 4393 & 7683 & 11396 & 17144 \\
\hline 71 & 13700 & 8296 & 8683 & 5881 & 3267 & 2945 & 2439 & 3050 & 7109 & 11511 & 16454 & 23250 \\
\hline 72 & 6911 & 5657 & 4395 & 2816 & 2764 & 2394 & 1299 & 1513 & 4102 & 4855 & 9189 & 12230 \\
\hline 73 & 7979 & 6100 & 3830 & 3682 & 2551 & 1075 & 1425 & 2108 & 4066 & 9069 & 12327 & 15946 \\
\hline 74 & 4206 & 2967 & 1946 & 1271 & 1196 & 611 & 182 & 241 & 1345 & 5355 & 6727 & 11330 \\
\hline 75 & 6396 & 3299 & 3056 & 839 & 164 & .nd & .nd & .nd & 357 & 5243 & 10640 & 13168 \\
\hline 76 & 3286 & 2472 & 271 & 346 & .nd & .nd & .nd & .nd & 491 & 2166 & 4411 & 7945 \\
\hline 77 & 2734 & 939 & 328 & .nd & .nd & .nd & .nd & .nd & 165 & 1646 & 5522 & 9823 \\
\hline 78 & 966 & 164 & .nd & .nd & .nd & .nd & .nd & .nd & .nd & 1013 & 2579 & 5149 \\
\hline 79 & 328 & 164 & .nd & .nd & .nd & .nd & nd & .nd & .nd & 165 & 3188 & 6473 \\
\hline 80 & .nd & .nd & .nd & .nd & .nd & .nd & .nd & .nd & .nd & .nd & 1340 & 2656 \\
\hline 81 & .nd & .nd & .nd & .nd & .nd & .nd & .nd & .nd & .nd & .nd & .nd & 2475 \\
\hline 82 & .nd & .nd & .nd & .nd & .nd & .nd & .nd & .nd & .nd & .nd & .nd & 1005 \\
\hline 83 & .nd & nd & .nd & .nd & .nd & .nd & .nd & .nd & .nd & .nd & .nd & 165 \\
\hline 84 & .nd & .nd & .nd & .nd & .nd & .nd & .nd & .nd & .nd & .nd & .nd & .nd \\
\hline 85 & .nd & nd & .nd & .nd & .nd & .nd & .nd & .nd & .nd & .nd & .nd & .nd \\
\hline 86 & .nd & .nd & .nd & .nd & .nd & .nd & .nd & .nd & .nd & .nd & .nd & .nd \\
\hline 87 & .nd & .nd & .nd & . & .nd & .nd & .nd & .nd & .nd & .nd & .nd & .nd \\
\hline 88 & .nd & .nd & .nd & .nd & .nd & .nd & .nd & .nd & .nd & .nd & .nd & .nd \\
\hline 89 & .nd & .nd & .nd & .nd & .nd & .nd & .nd & .nd & .nd & .nd & .nd & .nd \\
\hline
\end{tabular}

nd = no data available 


\begin{tabular}{|c|c|c|c|c|c|c|c|c|c|c|c|c|}
\hline \multirow[b]{2}{*}{ hour - } & \multicolumn{2}{|c|}{ Table } & \multicolumn{2}{|c|}{$\begin{array}{c}\text { cont'd: Central } \\
\text { Number of }\end{array}$} & \multicolumn{2}{|c|}{$\begin{array}{l}\text { Alr Conditione } \\
\text { Observatlons to }\end{array}$} & \multirow{2}{*}{$\begin{array}{c}\text { Raw } \\
\text { or all } \\
19\end{array}$} & \multicolumn{3}{|c|}{$\begin{array}{l}\text { Time-Temperature } \\
\text { CEC Reglons }\end{array}$} & \multicolumn{2}{|c|}{ Matrix } \\
\hline & 13 & 14 & 15 & 16 & 17 & 18 & & 20 & 21 & 22 & 23 & 24 \\
\hline 45 & 3618 & 3355 & 1780 & 1439 & 1333 & 2141 & 3344 & 4371 & 6078 & 7608 & 9425 & 8811 \\
\hline 46 & 3058 & 2604 & 2612 & 1577 & 1213 & 2165 & 2984 & 4119 & 4170 & 4657 & 5361 & 8857 \\
\hline 47 & 4000 & 3419 & 2938 & 3469 & 4510 & 4627 & 5297 & 5726 & 7241 & 9824 & 11648 & 12620 \\
\hline 48 & 2178 & 2777 & 1951 & 2337 & 2525 & 2760 & 3778 & 4166 & 6107 & 8291 & 9506 & 10738 \\
\hline 49 & 5023 & 3893 & 4436 & 3722 & 3721 & 4945 & 7138 & 10090 & 11210 & 13691 & 15372 & 16883 \\
\hline 50 & 4766 & 3866 & 3087 & 2919 & 2998 & 2983 & 4447 & 7451 & 9188 & 10139 & 11549 & 10828 \\
\hline 51 & 7474 & 6354 & 6466 & 6088 & 6019 & 8236 & 10160 & 14489 & 15860 & 16389 & 16285 & 18403 \\
\hline 52 & 6686 & 4758 & 4915 & 4886 & 4640 & 6374 & 10025 & 9702 & 11244 & 13011 & 13141 & 13640 \\
\hline 53 & 11964 & 10544 & 8642 & 8548 & 9134 & 11216 & 16609 & 19709 & 20545 & 20695 & 22327 & 24275 \\
\hline 54 & 10900 & 6051 & 6661 & 5912 & 6342 & 9444 & 11200 & 13351 & 15234 & 14131 & 18572 & 17804 \\
\hline 55 & 18846 & 16010 & 11181 & 11917 & 12819 & 17406 & 19922 & 19350 & 19806 & 26341 & 24903 & 25665 \\
\hline 56 & 11761 & 13316 & 13615 & 11893 & 13873 & 15157 & 15873 & 15164 & 17125 & 19409 & 19717 & 19292 \\
\hline 57 & 21917 & 19842 & 19742 & 19867 & 18725 & 19052 & 18932 & 21879 & 28156 & 26086 & 28108 & 31034 \\
\hline 58 & 12471 & 13310 & 12775 & 12938 & 13250 & 11711 & 13465 & 16462 & 17865 & 18526 & 19417 & 20273 \\
\hline 59 & 23527 & 21086 & 20273 & 21889 & 20985 & 22617 & 21066 & 26110 & 23364 & 27840 & 29968 & 32546 \\
\hline 60 & 15805 & 14411 & 13344 & 12615 & 14276 & 14211 & 16381 & 15561 & 19100 & 20953 & 20636 & 21460 \\
\hline 61 & 28892 & 25659 & 19507 & 18899 & 20189 & 20789 & 25186 & 24522 & 31237 & 30669 & 32394 & 34258 \\
\hline 62 & 16192 & 17686 & 19923 & 15038 & 14264 & 16596 & 17691 & 20254 & 16089 & 20894 & 25289 & 27398 \\
\hline 63 & 34219 & 28215 & 28203 & 28603 & 28433 & 28493 & 24459 & 27189 & 28646 & 32537 & 36132 & 37513 \\
\hline 64 & 19696 & 17415 & 17860 & 18667 & 17397 & 14603 & 16026 & 14415 & 19096 & 20715 & 22228 & 22433 \\
\hline 65 & 31740 & 31749 & 29993 & 29105 & 28376 & 26090 & 23963 & 25883 & 28759 & 31567 & 31709 & 30630 \\
\hline 66 & 20602 & 20251 & 19605 & 18716 & 17162 & 16002 & 14742 & 17273 & 18448 & 20528 & 16320 & 15148 \\
\hline 67 & 34208 & 32429 & 28056 & 27283 & 27852 & 27538 & 26023 & 25012 & 28316 & 24962 & 24764 & 18177 \\
\hline 68 & 24159 & 19697 & 18805 & 18752 & 17791 & 16029 & 14520 & 17428 & 16626 & 14753 & 10592 & 10716 \\
\hline 69 & 33408 & 29517 & 31336 & 28612 & 26582 & 26280 & 26152 & 24246 & 23567 & 20796 & 14346 & 14800 \\
\hline 70 & 16591 & 20570 & 19475 & 21079 & 19431 & 16205 & 15171 & 14811 & 13173 & 9574 & 9438 & 6982 \\
\hline 71 & 30787 & 29101 & 26372 & 27167 & 27945 & 25406 & 25687 & 21565 & 19610 & 14240 & 12711 & 12592 \\
\hline 72 & 16263 & 17605 & 17715 & 14852 & 15713 & 17138 & 13437 & 15200 & 10455 & 8332 & 8137 & $808 ?$ \\
\hline 73 & 23316 & 29296 & 26094 & 26094 & 24857 & 22067 & 22945 & 18065 & 13549 & 11887 & 13056 & 11704 \\
\hline 74 & 13049 & 15772 & 18104 & 15204 & 16494 & 17258 & 11783 & 10614 & 9321 & 9405 & 7219 & 6037 \\
\hline 75 & 14975 & 20654 & 26316 & 25531 & 22332 & 19599 & 19927 & 15331 & 9398 & 13386 & 10500 & 7429 \\
\hline 76 & 13117 & 12295 & 13935 & 17421 & 16217 & 14103 & 12970 & 8577 & 10724 & 7025 & 7399 & 3335 \\
\hline 77 & 14051 & 17407 & 16967 & 18711 & 18458 & 17407 & 15180 & 12155 & 14059 & 10612 & 6664 & 6538 \\
\hline 78 & 7917 & 9746 & 12030 & 11747 & 10851 & 11586 & 8898 & 10344 & 8169 & 5185 & 3457 & 1367 \\
\hline 79 & 11197 & 14201 & 15859 & 16853 & 18210 & 15964 & 15212 & 14002 & 9640 & 6139 & 4158 & 2733 \\
\hline 80 & 4937 & 7316 & 10586 & 10755 & 10198 & 11469 & 10889 & 7389 & 4958 & 3275 & 2697 & 816 \\
\hline 81 & 5700 & 10302 & 11975 & 14681 & 16317 & 15793 & 13485 & 11092 & 7138 & 3902 & 1142 & .nd \\
\hline 82 & 3419 & 3995 & 6119 & 6869 & 8274 & 7291 & 6205 & 4724 & 3087 & 1414 & 77 & .nd \\
\hline 83 & 1596 & 6569 & 8665 & 9636 & 8890 & 9008 & 8868 & 8149 & 4244 & 562 & .nd & .nd \\
\hline 84 & 484 & 1961 & 4092 & 5720 & 6141 & 5935 & 5363 & 4409 & 1260 & .nd & .nd & .nd \\
\hline 85 & 165 & 1352 & 3586 & 6586 & 7630 & 7034 & 6923 & 2787 & 733 & .nd & .nd & .nd \\
\hline 86 & .nd & 156 & 1382 & 1147 & 2450 & 3619 & 1483 & 1234 & .nd & .nd & .nd & .nd \\
\hline 87 & .nd & .nd & nd & 1409 & 2117 & 2189 & 1945 & 524 & .nd & .nd & .nd & .nd \\
\hline 88 & .nd & nd & .nd & 282 & 368 & 292 & 39 & .nd & .nd & .nd & .nd & .nd \\
\hline 89 & .nd & .nd & .nd & .nd & 50 & 165 & 164 & .nd & .nd & .nd & .nd & .nd \\
\hline
\end{tabular}

.nd = no data avaibable 


\begin{tabular}{|c|c|c|c|c|c|c|c|c|c|c|c|c|}
\hline \multirow[b]{2}{*}{ hour - } & \multirow[b]{2}{*}{1} & \multirow{2}{*}{$\begin{array}{c}\text { Table } \mathrm{C} \\
2\end{array}$} & \multicolumn{2}{|c|}{$\begin{array}{l}\text { Central } \\
\text { Number }\end{array}$} & \multicolumn{2}{|c|}{$\begin{array}{l}\text { Conditioner } \\
\text { Observations }\end{array}$} & \multirow{2}{*}{$\begin{array}{c}\text { Raw Tim } \\
\text { for CEC } \\
7\end{array}$} & \multicolumn{2}{|c|}{$\begin{array}{l}\text { e-Temperature } \\
\text { Region } 2\end{array}$} & \multicolumn{2}{|c|}{ Matrix } & \multirow[b]{2}{*}{12} \\
\hline & & & 3 & 4 & 5 & 6 & & 8 & 9 & 10 & 11 & \\
\hline 45 & 2492 & 1945 & 2330 & 2442 & 2745 & 2947 & 3021 & 2992 & 2347 & 1649 & 1608 & 1006 \\
\hline 46 & 1515 & 2053 & 1778 & 1986 & 1904 & 1583 & 1986 & 1709 & 1298 & 1514 & 617 & 708 \\
\hline 47 & 2305 & 2730 & 3074 & 2383 & 2585 & 2967 & 2930 & 2428 & 2155 & 2356 & 1308 & 1119 \\
\hline 48 & 1946 & 2010 & 1889 & 1656 & 2289 & 2515 & 2598 & 2830 & 2012 & 1033 & 1329 & 722 \\
\hline 49 & 3429 & 3234 & 3150 & 3924 & 3825 & 3996 & 4322 & 3749 & 2872 & 2653 & 2286 & 1244 \\
\hline 50 & 2377 & 2607 & 2351 & 2899 & 2945 & 3635 & 2726 & 2760 & 2491 & 2100 & 1481 & 1500 \\
\hline 51 & 3191 & 3141 & 4524 & 4274 & 4536 & 4225 & 4122 & 4368 & 2942 & 2324 & 2212 & 1879 \\
\hline 52 & 2606 & 3335 & 2960 & 3613 & 3010 & 2959 & 3993 & 2526 & 2350 & 2061 & 1915 & 1423 \\
\hline 53 & 4284 & 5021 & 4603 & 4578 & 4615 & 4823 & 4753 & 4694 & 4829 & 3580 & 2994 & 2505 \\
\hline 54 & 3063 & 3182 & 3098 & 2974 & 3127 & 3346 & 3277 & 3423 & 2556 & 2498 & 2028 & 1858 \\
\hline 55 & 5111 & 4750 & 5290 & 5604 & 6098 & 6114 & 6204 & 6045 & 5456 & 3660 & 3332 & 3540 \\
\hline 56 & 4310 & 4094 & 4382 & 4881 & 4415 & 4205 & 3980 & 4556 & 3304 & 3828 & 2078 & 2521 \\
\hline 57 & 5014 & 5891 & 6054 & 6252 & 7183 & 7516 & 8364 & 7692 & 6747 & 5001 & 4831 & 3414 \\
\hline 58 & 4024 & 4562 & 5078 & 4864 & 4601 & 4821 & 5945 & 5571 & 4379 & 2859 & 2982 & 1990 \\
\hline 59 & 7261 & 7140 & 6726 & 7476 & 8535 & 8858 & 8577 & 7133 & 6790 & 6380 & 4597 & 4561 \\
\hline 60 & 4165 & 4168 & 5692 & 5311 & 5008 & 4732 & 3994 & 4748 & 4371 & 4426 & 3485 & 3044 \\
\hline 61 & 6661 & 7079 & 6639 & 6559 & 5643 & 5324 & 5162 & 5589 & 6546 & 5338 & 5740 & 4512 \\
\hline 62 & 3828 & 4514 & 4139 & 3636 & 3671 & 3270 & 2398 & 3086 & 4182 & 4271 & 3924 & 2942 \\
\hline 63 & 6690 & 5358 & 4716 & 3894 & 3128 & 2475 & 2797 & 3242 & 5310 & 6249 & 5791 & 5329 \\
\hline 64 & 3579 & 2870 & 2113 & 1898 & 1848 & 2032 & 1423 & 1774 & 3244 & 4196 & 2995 & 4066 \\
\hline 65 & 3083 & 2704 & 2096 & 2467 & 2058 & 1263 & 893 & 1573 & 3142 & 5580 & 5608 & 4402 \\
\hline 66 & 2287 & 1890 & 1834 & 1053 & 704 & 639 & 361 & 488 & 1757 & 3635 & 3851 & 3724 \\
\hline 67 & 2154 & 1881 & 1196 & 731 & 510 & 343 & 322 & 555 & 1784 & 3614 & 5564 & 4667 \\
\hline 68 & 1308 & 792 & 450 & 395 & 196 & 142 & 86 & 116 & 963 & 2050 & 3322 & 3066 \\
\hline 69 & 1197 & 939 & 573 & 290 & 191 & 108 & 49 & 240 & 632 & 2420 & 4953 & 6025 \\
\hline 70 & 488 & 204 & 167 & 50 & .nd & .nd & .nd & .nd & 310 & 994 & 2296 & 3228 \\
\hline 71 & 504 & 109 & 50 & .nd & .nd & 49 & .nd & .nd & 108 & 1471 & 2338 & 4580 \\
\hline 72 & 119 & .nd & .nd & .nd & 49 & .nd & .nd & .nd & 47 & 491 & 1370 & 2403 \\
\hline 73 & 50 & .nd & .nd & .nd & .nd & .nd & .nd & .nd & 108 & 288 & 1997 & 3437 \\
\hline 74 & .nd & nd & .nd & .nd & .nd & .nd & .nd & .nd & .nd & .nd & 717 & 1139 \\
\hline 75 & .nd & .nd & .nd & .nd & .nd & .nd & .nd & .nd & .nd & 216 & 874 & 2142 \\
\hline 76 & .r.d & .nd & .nd & .nd & .nd & .nd & nd & .nd & .nd & 47 & 115 & 1353 \\
\hline 77 & .nd & .nd & .nd & .nd & .nd & .nd & .nd & .nd & .nd & .nd & 99 & 988 \\
\hline 78 & nd & .nd & .nd & .nd & .nd & .nd & .nd & .nd & .nd & .nd & 106 & 263 \\
\hline 79 & .nd & nd & .nd & .nd & .nd & .nd & .nd & .nd & .nd & .nd & .nd & 567 \\
\hline 80 & .nd & .nd & nd & .nd & .nd & .nd & .nd & .nd & .nd & .nd & .nd & .nd \\
\hline 81 & .nd & .nd & .nd & .nd & .nd & .nd & .nd & .nd & .nd & .nd & .nd & .nd \\
\hline 82 & .nd & nd & .nd & .nd & .nd & .nd & .nd & .nd & .nd & .nd & .nd & .nd \\
\hline 83 & .nd & .nd & .nd & .nd & .nd & .nd & .nd & .nd & .nd & .nd & .nd & .nd \\
\hline 84 & .nd & .nd & .nd & .nd & .nd & .nd & .nd & .nd & .nd & .nd & .nd & .nd \\
\hline 85 & .nd & .nd & .nd & .nd & .nd & .nd & .nd & .nd & .nd & .nd & .nd & .nd \\
\hline 86 & .nd & .nd & nd & .nd & .nd & .nd & .nd & .nd & .nd & .nd & .nd & .nd \\
\hline 87 & nd & .nd & nd & .nd & .nd & .nd & nd & .nd & .nd & .nd & .nd & .nd \\
\hline 88 & .nd & .nd & .nd & .nd & nd & .nd & .nd & .nd & nd & .nd & .nd & .nd \\
\hline 89 & .nd & .nd & .nd & .nd & .nd & nd & .nd & .nd & nd & nd & nd & .nd \\
\hline
\end{tabular}




\begin{tabular}{|c|c|c|c|c|c|c|c|c|c|c|c|c|}
\hline \multirow[b]{2}{*}{ hour -} & \multirow{2}{*}{$\begin{array}{l}\text { Table } \\
13\end{array}$} & \multicolumn{3}{|c|}{$\begin{array}{r}\text { e cont'd: Central } \\
\text { Number of }\end{array}$} & \multicolumn{3}{|c|}{$\begin{array}{l}\text { Air Conditioner Raw } \\
\text { Observations for CEC }\end{array}$} & \multicolumn{4}{|c|}{$\begin{array}{l}\text { Time-Temperature Matrix } \\
\text { Region } 2\end{array}$} & \multirow[b]{2}{*}{24} \\
\hline & & 14 & 15 & 16 & 17 & 18 & 19 & 20 & 21 & 22 & 23 & \\
\hline 45 & 742 & 966 & 586 & 426 & 430 & 803 & 1115 & 1377 & 1807 & 1831 & 1493 & 1783 \\
\hline 46 & 649 & 433 & 581 & 427 & 526 & 512 & 775 & 976 & 703 & 1014 & 1214 & 1984 \\
\hline 47 & 1209 & 828 & 774 & 990 & 848 & 953 & 1228 & 1163 & 1483 & 1541 & 2147 & 2128 \\
\hline 48 & 282 & 597 & 522 & 446 & 536 & 732 & 737 & 845 & 1624 & 1830 & 1696 & 1840 \\
\hline 49 & 1150 & 729 & 795 & 865 & 766 & 978 & 1125 & 1819 & 2559 & 3109 & 3357 & 3568 \\
\hline 50 & 1000 & 932 & 450 & 443 & 620 & 463 & 1208 & 1522 & 1491 & 1564 & 1965 & 1992 \\
\hline 51 & 1518 & 1396 & $130 i$ & 935 & 1236 & 1837 & 1790 & 3074 & 2816 & 2993 & 3223 & 3390 \\
\hline 52 & 1053 & 933 & 1104 & 1518 & 998 & 1140 & 1950 & 1586 & 1775 & 1871 & 2109 & 2350 \\
\hline 53 & 2151 & 1812 & 1430 & 1315 & 1684 & 1987 & 2841 & 3015 & 3366 & 3042 & 3544 & 3302 \\
\hline 54 & 1903 & 1436 & 1464 & 1327 & 1359 & 1489 & 1461 & 1791 & 2196 & 3123 & 2900 & 3374 \\
\hline 55 & 2317 & 2136 & 2289 & 2292 & 2180 & 2912 & 3131 & 3318 & 3514 & 3946 & 4507 & 5180 \\
\hline 56 & 2874 & 1558 & 1620 & 1412 & 1668 & 1781 & 2269 & 2536 & 2381 & 3141 & 3375 & 3435 \\
\hline 57 & 3087 & 3846 & 3351 & 3115 & 2969 & 3594 & 3366 & 3801 & 4320 & 4915 & 5111 & 4916 \\
\hline 58 & 2036 & 2261 & 1933 & 2285 & 2165 & 1291 & 2424 & 1750 & 3378 & 2500 & 2735 & 3114 \\
\hline 59 & 3725 & 3206 & 3245 & 3739 & 3576 & 4124 & 3055 & 4273 & 3948 & 5063 & 5621 & 6902 \\
\hline 60 & 1840 & 2372 & 2165 & 1416 & 1983 & 1770 & 2314 & 2698 & 2724 & 3776 & 4008 & 4958 \\
\hline 61 & 4264 & 3531 & 3440 & 2892 & 3467 & 4024 & 3487 & 4000 & 4704 & 4814 & 5756 & 5780 \\
\hline 62 & 3224 & 2530 & 2564 & 2799 & 1845 & 2439 & 2959 & 2324 & 3589 & 3384 & 3878 & 4261 \\
\hline 63 & 5238 & 5082 & 4635 & 3753 & 4509 & 3379 & 3438 & 4041 & 2999 & 4740 & 6440 & 6007 \\
\hline 64 & 2977 & 2785 & 3239 & 3226 & 2727 & 2598 & 2163 & 2450 & 3086 & 3794 & 3349 & 4161 \\
\hline 65 & 4585 & 4123 & 3266 & 4026 & 3281 & 2991 & 2803 & 3352 & 3894 & 4816 & 5254 & 4271 \\
\hline 66 & 3221 & 2775 & 2957 & 2580 & 2742 & 2464 & 2404 & 2745 & 2969 & 3665 & 3046 & 2635 \\
\hline 67 & 4674 & 4631 & 3745 & 3976 & 3661 & 3765 & 3498 & 2453 & 4041 & 4042 & 4294 & 2556 \\
\hline 68 & 3156 & 2694 & 2693 & 2410 & 2478 & 2226 & 1736 & 2451 & 3019 & 2871 & 1882 & 1964 \\
\hline 69 & 4766 & 4366 & 3999 & 3664 & 3674 & 3243 & 3061 & 3548 & 4062 & 4094 & 2372 & 1963 \\
\hline 70 & 2738 & 2623 & 2828 & 2776 & 2387 & 1834 & 1857 & 2589 & 2430 & 2011 & 1223 & 815 \\
\hline 71 & 5444 & 4525 & 3928 & 3186 & 3647 & 3338 & 3929 & 3366 & 3679 & 1960 & 1866 & 922 \\
\hline 72 & 2795 & 3141 & 2356 & 2365 & 2110 & 2037 & 2648 & 2217 & 2008 & 1378 & 834 & 257 \\
\hline 73 & 4114 & 4903 & 4977 & 4363 & 3655 & 3758 & 3794 & 4365 & 3041 & 1662 & 822 & 207 \\
\hline 74 & 2076 & 2511 & 3045 & 2994 & 2969 & 3587 & 2453 & 1968 & 1280 & 917 & 160 & .nd \\
\hline 75 & 4025 & 3703 & 4246 & 4058 & 4804 & 4014 & 3604 & 2891 & 1729 & 1330 & 203 & .nd \\
\hline 76 & 2093 & 2566 & 2216 & 3122 & 2250 & 2076 & 2648 & 1815 & 1203 & 143 & 49 & 50 \\
\hline 77 & 1882 & 3449 & 2810 & 2895 & 3160 & 3163 & 2830 & 2818 & 1747 & 210 & .nd & .nd \\
\hline 78 & 1358 & 2130 & 3084 & 2716 & 2182 & 2497 & 2124 & 1276 & 733 & 145 & .nd & .nd \\
\hline 79 & 1346 & 2261 & 3343 & 3433 & 3693 & 3631 & 2902 & 2121 & 997 & 50 & nd & .nd \\
\hline 80 & 440 & 904 & 1415 & 2021 & 2184 & 1908 & 1772 & 942 & 255 & .nd & .nd & .nd \\
\hline 81 & 438 & 1316 & 1950 & 2225 & 2575 & 2276 & 1721 & 1196 & 254 & .nd & .nd & .nd \\
\hline 82 & 97 & 360 & 1049 & 1379 & 1113 & 1508 & 821 & 570 & 58 & .nd & .nd & .nd \\
\hline 83 & .nd & 472 & 1079 & 1359 & 1906 & 1078 & 1813 & 983 & 49 & .nd & .nd & .nd \\
\hline 84 & .nd & 97 & 361 & 932 & 757 & 1234 & 657 & 185 & 49 & .nd & .nd & .nd \\
\hline 85 & .nd & .nd & 190 & 648 & 1027 & 797 & 413 & 97 & .nd & .nd & .nd & .nd \\
\hline 86 & .nd & .nd & .nd & 99 & 224 & 385 & 212 & 49 & nd & .nd & .nd & .nd \\
\hline 87 & .nd & .nd & .nd & 175 & 316 & 232 & 188 & 39 & .nd & .nd & .nd & .nd \\
\hline 88 & .nd & .nd & .nd & .nd & 39 & 128 & 39 & .nd & .nd & nd & .nd & .nd \\
\hline 89 & .nd & .nd & .nd & .nd & 50 & .nd & .nd & .nd & .nd & nd & .nd & .nd \\
\hline
\end{tabular}


Table C7: Central Air Conditioner Raw Time-Temperature Matrix Number of Observations for CEC Region 3

\begin{tabular}{|c|c|c|c|c|c|c|c|c|c|c|c|c|}
\hline & 1 & 2 & 3 & 4 & 5 & 6 & 7 & 8 & 9 & 10 & 11 & 12 \\
\hline 45 & 6902 & 7625 & 6976 & 6808 & 5767 & 5823 & 6716 & 6328 & 6195 & 4975 & 3664 & 2857 \\
\hline 46 & 4253 & 3339 & 3037 & 4207 & 4707 & 4384 & 4157 & 4023 & 4397 & 3517 & 2063 & 2170 \\
\hline 47 & 6224 & 6700 & 5969 & 5623 & 8204 & 8394 & 9283 & 8629 & 4969 & 5153 & 3747 & 2200 \\
\hline 48 & 4203 & 3552 & 5376 & 5737 & 5104 & 5201 & 4893 & 4521 & 5255 & 2860 & 3210 & 1462 \\
\hline 49 & 6973 & 8279 & 8367 & 9311 & 6952 & 7414 & 9898 & 8672 & 6723 & 7853 & 5134 & 3855 \\
\hline 50 & 5428 & 5227 & 5454 & 5830 & 6057 & 7984 & 6171 & 6838 & 5912 & 4693 & 3650 & 2840 \\
\hline 51 & 8857 & 8875 & 9316 & 8481 & 8803 & 9900 & 7739 & 10219 & 7277 & 6279 & 7066 & 5606 \\
\hline 52 & 4531 & 5622 & 5197 & 4806 & 5738 & 5498 & 8980 & 5531 & 5804 & 5252 & 4343 & 4543 \\
\hline 53 & 9813 & 8477 & 8744 & 11066 & 11772 & 11831 & 10295 & 11031 & 9818 & 7009 & 7892 & 7455 \\
\hline 54 & 5359 & 5559 & 5594 & 7654 & 6876 & 8246 & 8510 & 7320 & 7502 & 5100 & 4594 & 3332 \\
\hline 55 & 7492 & 9385 & 12235 & 10572 & 11260 & 10731 & 12664 & 12656 & 10265 & 9407 & 7724 & 7985 \\
\hline 56 & 6793 & 7971 & 8073 & 6326 & 7663 & 9675 & 936 & $85 s$ & 8648 & & & 4380 \\
\hline 57 & 11184 & 12361 & 12245 & 14347 & 14508 & 13640 & 14091 & 14788 & 13641 & & & 9537 \\
\hline 58 & 8865 & $65 €$ & 6732 & 6538 & 8745 & 7172 & 862 & & & & & 5143 \\
\hline 59 & 8807 & 10089 & 10243 & 11691 & 10951 & 14022 & 14461 & 105 & 13482 & 12529 & 111 & 8285 \\
\hline 60 & 6616 & 739 & 7572 & 9239 & & 10585 & 894 & 1 & & & & 5898 \\
\hline 61 & 11702 & 10147 & 115 & 1243 & 123 & 10920 & 119 & 10 & 12366 & 12 & & 10469 \\
\hline 62 & 5849 & 7372 & 80 & 73 & & 8586 & 7929 & & 9074 & 44 & 163 & 5921 \\
\hline 63 & 8877 & 12593 & 12783 & 13550 & 13660 & 14321 & 14980 & 137 & 11863 & 14547 & 14319 & 13224 \\
\hline 64 & 8615 & 6670 & 7920 & 8485 & 7507 & 6646 & 7132 & 7647 & 7995 & 8164 & 7319 & 7775 \\
\hline 65 & 10362 & 11932 & 11984 & 11618 & 10280 & 12663 & 10435 & 9864 & 10763 & 13383 & 11610 & 11078 \\
\hline 66 & 6550 & 6413 & 6489 & 5958 & 8220 & 5736 & 5484 & 6804 & 7108 & 6042 & 7501 & 9530 \\
\hline 67 & 10236 & 9962 & 9017 & 12005 & 10301 & 6172 & 5187 & 6438 & 10359 & 10761 & 13989 & 10304 \\
\hline 68 & 6394 & 7341 & 7808 & 5925 & 3065 & 3796 & 4435 & 3118 & 6298 & 6651 & 7242 & 6805 \\
\hline 69 & 9067 & 10569 & 9757 & 6219 & 6781 & 7131 & 4724 & 6074 & 6178 & 10114 & 9946 & 13893 \\
\hline 70 & 6171 & 6703 & 3742 & 4212 & 3974 & 2161 & 2264 & 2781 & 3579 & 5594 & 6240 & 7210 \\
\hline 71 & 11867 & 7419 & 7840 & 5336 & 2953 & 2613 & 2187 & 2761 & 6235 & 8305 & 11286 & 10833 \\
\hline 72 & 6071 & 5104 & 3963 & 2524 & 2450 & 2144 & 1163 & 1363 & 3666 & 3749 & 6092 & 7240 \\
\hline 73 & 7170 & 5539 & 3454 & 3318 & 2281 & 957 & 1280 & 1885 & 3560 & 7779 & 8577 & 8978 \\
\hline 74 & 3827 & 2676 & 1758 & 1136 & 1073 & 549 & 163 & 220 & 1123 & 4730 & 5219 & 8307 \\
\hline 75 & 5770 & 2962 & 2745 & 769 & 145 & .nd & .nd & .nd & 861 & 4482 & 8704 & 9156 \\
\hline 76 & 2956 & 2235 & 250 & 308 & .nd & .nd & .nd & .nd & 434 & 1895 & 3888 & 5744 \\
\hline 77 & 2476 & 842 & 290 & .nd & .nd & .nd & .nd & .nd & 146 & 1470 & 4786 & 7608 \\
\hline 78 & 867 & 145 & .nd & .nd & .nd & .nd & .nd & .nd & .nd & 903 & 2178 & 4382 \\
\hline 79 & 290 & 145 & .nd & .nd & .nd & .nd & .nd & .nd & .nd & 146 & 2850 & 5337 \\
\hline 80 & .nd & .nd & .nd & .nd & .nd & .nd & .nd & .nd & .nd & .nd & 1192 & 2386 \\
\hline 81 & .nd & .nd & .nd & .nd & .nd & .nd & .no & .nd & .nd & .nd & .nd & 2222 \\
\hline 82 & .nd & .nd & .nd & .nd & .nd & .nd & .no & .nd & .nd & .nd & .nd & 902 \\
\hline 83 & .nd & .nd & .nd & .nd & .nd & .nd &.$n$ & .nd & .nd & .nd & .nd & 146 \\
\hline 84 & .nd & .nd & .nd & .nd & .nd & .nd &.$n$ & .nd & .nd & .nd & .nd & .nd \\
\hline 55 & .nd & .nd & .nd & .nd & .nd & .nd &.$n$ &.$n$ & .nd & .nd & .nd & .nd \\
\hline 86 & .nd & .nd & .nd & .nd & .nd & .nd & .nc & .nd & .nd & .nd & .nd & .nd \\
\hline 87 & .nd & .nd & .nd & .nd & .nd & .nd & .nd & .nd & .nd & .nd & .nd & .nd \\
\hline 88 & .nd & .nd & .nd & .nd & .nd & .nd & .nd & .nd & .nd & .nd & .nd & .nd \\
\hline 89 & .nd & .nd & .nd & .nd & .nd & .nd & .nd & .nd & .nd & .nd & .nd & .nd \\
\hline
\end{tabular}




\begin{tabular}{|c|c|c|c|c|c|c|c|c|c|c|c|c|}
\hline \multirow[b]{2}{*}{ hour $\rightarrow$} & \multicolumn{2}{|c|}{ Table } & \multicolumn{2}{|c|}{$\begin{array}{l}\text { ont'd: Central } \\
\text { Number of }\end{array}$} & \multicolumn{2}{|c|}{$\begin{array}{l}\text { Alr Conditione } \\
\text { Observations }\end{array}$} & \multirow{2}{*}{$\begin{array}{c}\text { er Raw } \\
\text { for CEC } \\
19\end{array}$} & \multicolumn{3}{|c|}{$\begin{array}{l}\text { Time-Temperature } \\
=\text { Region } 3\end{array}$} & \multicolumn{2}{|c|}{ Matrix } \\
\hline & 13 & 14 & 15 & 16 & 17 & 18 & & 20 & 21 & 22 & 23 & 24 \\
\hline 45 & 2473 & 1938 & 981 & 833 & 720 & 1080 & 1857 & 2519 & 3432 & 4417 & 6443 & 5319 \\
\hline 46 & 2071 & 1770 & 1754 & 971 & 543 & 1378 & 1795 & 2383 & 2879 & 2604 & 2963 & 4938 \\
\hline 47 & 2159 & 2108 & 1510 & 1891 & 3052 & 3038 & 2941 & 3746 & 4163 & 6529 & 6844 & 5966 \\
\hline 48 & 1197 & 1849 & 1189 & 1494 & 1451 & 1502 & 2404 & 2090 & 3195 & 4360 & 4744 & 5189 \\
\hline 49 & 2965 & 2299 & 2713 & 2320 & 2418 & 3194 & 3811 & 5787 & 5695 & 5999 & 6037 & 6838 \\
\hline 50 & 2242 & 1906 & 2021 & 1873 & 1783 & 1789 & 1917 & 3919 & 4755 & 4556 & 5550 & 5069 \\
\hline 51 & 3799 & 3157 & 3857 & 3560 & 2779 & 3818 & 5246 & 6353 & 6437 & 6868 & 6129 & 7223 \\
\hline 52 & 3147 & 2317 & 2020 & 2039 & 2366 & 2809 & 4748 & 3342 & 4355 & 5285 & 5499 & 5532 \\
\hline 53 & 5319 & 5599 & 4278 & 4530 & 4971 & 4926 & 6005 & 8221 & 9824 & 8265 & 8568 & 9016 \\
\hline 54 & 4180 & 1815 & 2978 & 1972 & 1970 & 4196 & 5229 & 5896 & 5656 & 3859 & 5782 & 4938 \\
\hline 55 & 7834 & 6145 & 3958 & 4650 & 6203 & 7265 & 7120 & 6246 & 5408 & 9129 & 7875 & 8369 \\
\hline 56 & 4525 & 5892 & 5965 & 6126 & 6386 & 5693 & 7356 & 5351 & 5851 & 6067 & 5638 & 5788 \\
\hline 57 & 8942 & 7376 & 7443 & 7895 & 6819 & 7050 & 6122 & 8147 & 9794 & 8085 & 8954 & 10743 \\
\hline 58 & 5231 & 5500 & 5232 & 5208 & 5292 & 4973 & 4505 & 5372 & 5323 & 5421 & 6596 & 5649 \\
\hline 59 & 7989 & 8488 & 8567 & 8490 & 7606 & 7639 & 6712 & 9130 & 6785 & 8697 & 9042 & 10547 \\
\hline 60 & 5055 & 4968 & 4251 & 3701 & 5352 & 4760 & 6124 & 4959 & 7058 & 6141 & 6705 & 6210 \\
\hline 61 & 9121 & 8140 & 5491 & 6868 & 5935 & 5887 & 7966 & 6526 & 7530 & 8474 & 7235 & 8016 \\
\hline 62 & 3932 & 6103 & 7391 & 3871 & 4227 & 6243 & 5366 & 6288 & 4213 & 5255 & 68 & 7737 \\
\hline 63 & 12658 & 8552 & 8785 & 9665 & 10248 & 10340 & 7899 & 8102 & 8920 & 8885 & 9129 & 9919 \\
\hline 64 & 6254 & 5,402 & 5231 & 6863 & 6159 & 3643 & 5095 & 4210 & 5765 & 4836 & 5725 & 4730 \\
\hline 65 & 10952 & 11135 & 11357 & 9083 & 8564 & 7983 & 7165 & 8181 & 7528 & 6909 & 9700 & 11555 \\
\hline 66 & 6289 & 8066 & 7118 & 7014 & 5711 & 5225 & 4746 & 5486 & 5048 & 7448 & 5308 & 6133 \\
\hline 67 & 10580 & 9635 & 8265 & 8967 & 8855 & 9964 & 8423 & 7526 & 8706 & 9849 & 10731 & 10128 \\
\hline 68 & 8684 & 6121 & 7064 & 6482 & 6029 & 4301 & 3899 & 5315 & 5059 & 5860 & 5377 & 6251 \\
\hline 69 & 10966 & 10283 & 10116 & 7905 & 7684 & 8636 & 8388 & 6939 & 8648 & 10621 & 8298 & 10005 \\
\hline 70 & 6585 & 6710 & 6393 & 8134 & 6717 & 4528 & 5089 & 4034 & 5129 & 4927 & 7009 & 5159 \\
\hline 71 & 11566 & 10100 & 9746 & 10151 & 9475 & 9016 & 7690 & 8325 & 11173 & 9603 & 8783 & 10148 \\
\hline 72 & 7746 & 6690 & 5513 & 4202 & 4635 & 5934 & 4786 & 7174 & 5452 & 5874 & 6350 & 7123 \\
\hline 73 & 11153 & 12531 & 10472 & 8841 & 9661 & 7177 & 8899 & 7605 & 8201 & 8428 & 11074 & 10330 \\
\hline 74 & 7711 & 7193 & 7024 & 5495 & 6122 & 6368 & 4630 & 6506 & 6625 & 7643 & 6305 & 5458 \\
\hline 75 & 7924 & 11352 & 12560 & 11385 & 9612 & 8930 & 10299 & 9436 & 6289 & 10927 & 9333 & 6723 \\
\hline 76 & 9356 & 6672 & 7526 & 9932 & 8966 & 8089 & 7726 & 5375 & 8153 & 6110 & 6640 & 2974 \\
\hline 77 & 9884 & 9967 & 9371 & 9434 & 10150 & 9810 & 9264 & 7426 & 11125 & 9404 & 6063 & 5917 \\
\hline 78 & 5490 & 6076 & 6559 & 6304 & 5816 & 6646 & 5121 & 7896 & 6628 & 4613 & 3114 & 1230 \\
\hline 79 & 8825 & 10344 & 9826 & 10473 & 10836 & 9562 & 10275 & 10470 & 7798 & 5512 & 3750 & 2440 \\
\hline 80 & 4098 & 5456 & 7758 & 6756 & 6293 & 7924 & 8013 & 5830 & 4295 & 2945 & 2438 & 736 \\
\hline 81 & 4672 & 8191 & 8551 & 10942 & 11809 & 11783 & 10505 & 8887 & 6219 & 3520 & 1012 & .nd \\
\hline 82 & 2985 & 3314 & 4611 & 4657 & 6048 & 4935 & 4896 & 3780 & 2754 & 1267 & 75 & .nd \\
\hline 83 & 1426 & 5383 & 6898 & 7454 & 6390 & 7246 & 6334 & 6500 & 3782 & 506 & .nd & .nd \\
\hline 84 & 430 & 1687 & 3352 & 4334 & 4893 & 4285 & 4257 & 3824 & 1083 & .nd & .nd & .nd \\
\hline 85 & 146 & 1199 & 2952 & 5361 & 5950 & 5508 & 5885 & 2417 & 655 & .nd & nd & .nd \\
\hline 86 & .nd & 140 & 1231 & 833 & 1918 & 2921 & 1151 & 1054 & .nd & .nd & .nd & .nd \\
\hline 87 & .nd & .nd & .nd & 1090 & 1598 & 1737 & 1555 & 431 & .nd & .nd & .nd & .nd \\
\hline 88 & .nd & .nd & .nd & 250 & 291 & 145 & .nd & .nd & .nd & nd & .nd & .nd \\
\hline 89 & .nd & .nd & .nd & nd & .nd & 146 & 145 & .nd & .nd & .nd & .nd & .nd \\
\hline
\end{tabular}




\begin{tabular}{|c|c|c|c|c|c|c|c|c|c|c|c|c|}
\hline \multirow[b]{2}{*}{ hour $\rightarrow$} & \multirow[b]{2}{*}{1} & \multirow{2}{*}{$\begin{array}{c}\text { Table } C 8 \\
2\end{array}$} & \multicolumn{2}{|c|}{$\begin{array}{l}\text { 8: Central } \\
\text { Number }\end{array}$} & \multicolumn{2}{|c|}{$\begin{array}{l}\text { Conditioner } \\
\text { Observations }\end{array}$} & \multicolumn{3}{|c|}{$\begin{array}{l}\text { Raw Time-Temperature } \\
\text { for CEC Region } 4\end{array}$} & \multicolumn{2}{|c|}{ Matrix } & \multirow[b]{2}{*}{12} \\
\hline & & & 3 & 4 & 5 & 6 & 7 & 8 & 9 & 10 & 11 & \\
\hline 45 & 1733 & 2643 & 3219 & 4534 & 4429 & 4960 & 5742 & 5183 & 4996 & 1575 & 343 & 223 \\
\hline 46 & 2393 & 2755 & 3468 & 3158 & 2923 & 3117 & 3228 & 4198 & 3090 & 2554 & 861 & 119 \\
\hline 47 & 3842 & 4414 & 4023 & 4243 & 5517 & 5687 & 6949 & 6580 & 5026 & 2769 & 972 & 463 \\
\hline 48 & 3855 & 2779 & 2986 & 3701 & 4182 & 4528 & 4083 & 3392 & 3042 & 2486 & 1190 & 443 \\
\hline 49 & 4406 & 5261 & 7601 & 6600 & 5864 & 7126 & 7031 & 6913 & 5450 & 4271 & 2669 & 1446 \\
\hline 50 & 4155 & 5951 & 4602 & 4971 & 5442 & 4749 & 5670 & 4645 & 4115 & 3390 & 2069 & 1339 \\
\hline 51 & 7260 & 5954 & 6799 & 8619 & 8875 & 10224 & 9115 & 8484 & 5232 & 5713 & 4549 & 2629 \\
\hline 52 & 4353 & 5568 & 7447 & 7572 & 8309 & 7488 & 6618 & 6268 & 4818 & 4133 & 3782 & 3255 \\
\hline 53 & 11150 & 11916 & 12174 & 11416 & 11185 & 10975 & 11770 & 11300 & 8719 & 7863 & 6127 & 5395 \\
\hline 54 & 7447 & 8653 & 9016 & 9305 & 8856 & 8031 & 8249 & 7114 & 7196 & 4952 & 5434 & 3901 \\
\hline 55 & 12586 & 12952 & 12005 & 10860 & 10375 & 12340 & 12832 & 12288 & 13234 & 9257 & 8641 & 6292 \\
\hline 56 & 8856 & 8241 & 7223 & 9565 & 9578 & 10238 & 10404 & 9856 & 6859 & 7970 & 6801 & 5610 \\
\hline 57 & 11450 & 12101 & 13098 & 12207 & 13749 & 12556 & 13232 & 14410 & 13825 & 11025 & 9263 & 9662 \\
\hline 58 & 8061 & 9960 & 8941 & 8704 & 9654 & 10359 & 10035 & 10770 & 9924 & 8403 & 6962 & 5511 \\
\hline 59 & 13482 & 13587 & 14264 & 15215 & 14936 & 15892 & 17207 & 15617 & 16691 & 15241 & 12058 & 12346 \\
\hline 60 & 9368 & 10045 & 10254 & 10949 & 11711 & 10937 & 11767 & 12950 & 11406 & 11700 & 9625 & 7402 \\
\hline 61 & 19984 & 17849 & 17945 & 17097 & 16661 & 18434 & 18535 & 18242 & 21203 & 20159 & 19010 & 15680 \\
\hline 62 & 15067 & 11491 & 10625 & 12145 & 12390 & 10676 & 11799 & 11009 & 12799 & 13092 & 9609 & 8873 \\
\hline 63 & 20393 & 17270 & 17370 & 16310 & 16308 & 13997 & 11614 & 13717 & 17242 & 19997 & 19672 & 14684 \\
\hline 64 & 10327 & 11158 & 10388 & 9095 & 5647 & 6163 & 4742 & 4923 & 7719 & 12295 & 12212 & 10818 \\
\hline 65 & 11828 & 11785 & 8288 & 7370 & 7267 & 5305 & 3318 & 3723 & 7748 & 13532 & 19007 & 16944 \\
\hline 66 & 3035 & 3724 & 4220 & 2658 & 1584 & 1134 & 1202 & 1735 & 2146 & 5681 & 10232 & 11454 \\
\hline 67 & 3517 & 2977 & 1910 & 1938 & 1277 & 710 & 187 & 444 & 2897 & 7294 & 12365 & 18596 \\
\hline 68 & 1375 & 1186 & 747 & 119 & nd & 110 & .nd & 114 & 804 & 2315 & 6128 & 7812 \\
\hline 69 & 997 & 429 & 197 & 110 & 110 & .nd & .nd & 77 & 1021 & 1899 & 6440 & 12194 \\
\hline 70 & 120 & .nd & .nd & .nd & .nd & .nd & .nd & 199 & 112 & 496 & 2079 & 5796 \\
\hline 71 & 87 & .nd & .nd & .nd & .nd & .nd & .nd & .nd & 114 & 819 & 1556 & 6619 \\
\hline 72 & 110 & nd & .nd & .nd & .nd & .nd & .nd & .nd & .nd & 220 & 1070 & 1704 \\
\hline 73 & .nd & .nd & .nd & .nd & .nd & .nd & .nd & .nd & .nd & 197 & 787 & 2498 \\
\hline 74 & .nd & .nd & .nd & .nd & .nd & .nd & nd & .nd & 87 & 114 & 215 & 932 \\
\hline 75 & .nd & .nd & .nd & .nd & .nd & .nd & .nd & .nd & .nd & 87 & 197 & 888 \\
\hline 76 & .nd & .nd & .nd & .nd & .nd & .nd & .nd & .nd & .nd & .nd & .nd & 207 \\
\hline 77 & .nd & nd & .nd & .nd & .nd & .nd & .nd & .nd & .nd & .nd & 114 & 433 \\
\hline 78 & .nd & .nd & .nd & .nd & .nd & .nd & .nd & .nd & .nd & .nd & 87 & 110 \\
\hline 79 & .nd & .nd & .nd & .nd & .nd & .nd & nd & .nd & .nd & .nd & .nd & no \\
\hline 80 & .nd & .nd & .nd & .nd & .nd & .nd & .nd & .nd & .nd & .nd & .nd & no \\
\hline 81 & .nd & nd & .nd & .nd & .nd & .nd & .nd & .nd & .nd & .nd & .nd & no \\
\hline 82 & nd & .nd & .nd & .nd & .nd & .nd & .nd & .nd & .nd & .nd & .nd & no \\
\hline 83 & nd & nd & .nd & .nd & .nd & .nd & .nd & .nd & .nd & .nd & .nd & no \\
\hline 85 & .nd & .nd & .nd & .nd & .nd & .nd & .nd & .nd & .nd & .nd & .nd & no \\
\hline 86 & nd & .nd & .nd & .nd & .nd & .nd & .nd & .nd & .nd & .nd & .nd & no \\
\hline 87 & .nd & .nd & .nd & .nd & .nd & .nd & .nd & .nd & .nd & .nd & .nd & no \\
\hline 88 & nd & .nd & .nd & .nd & .nd & .nd & .nd & nd & .nd & .nd & .nd & no \\
\hline 89 & .nd & .nd & .nd & .nd & .nd & .nd & .nd & .nd & .nd & .nd & .nd & no \\
\hline
\end{tabular}

nd $=$ no data avalable 


\begin{tabular}{|c|c|c|c|c|c|c|c|c|c|c|c|c|}
\hline \multirow[b]{2}{*}{ hour } & Table & C8 & \multicolumn{2}{|c|}{$\begin{array}{c}\text { cont'd: Central } \\
\text { Number of }\end{array}$} & \multicolumn{2}{|c|}{$\begin{array}{l}\text { Air Conditione } \\
\text { Observations }\end{array}$} & $\begin{array}{l}\text { Raw } \\
\text { or CEC }\end{array}$ & \multicolumn{3}{|c|}{$\begin{array}{l}\text { Time-Temperature } \\
\text { Region } 4\end{array}$} & \multicolumn{2}{|l|}{ Matrix } \\
\hline & 13 & 14 & 15 & 16 & 17 & 18 & 19 & 20 & 21 & 22 & 23 & 24 \\
\hline 45 & .nd & 118 & .nd & .nd & .nd & .nd & .nd & .nd & 269 & 683 & 567 & 891 \\
\hline 46 & .nd & 118 & .nd & nd & .nd & .nd & 118 & 374 & 120 & 589 & 720 & 1194 \\
\hline 47 & 238 & 119 & 355 & 236 & 118 & 118 & 595 & 170 & 907 & 764 & 1595 & 3538 \\
\hline 48 & 456 & .nd & .nd & 119 & 237 & 269 & 238 & 855 & 783 & 1430 & 2297 & 2864 \\
\hline 49 & 344 & 446 & 455 & 118 & 118 & 222 & 1514 & 1566 & 1986 & 3545 & 4856 & 5200 \\
\hline 50 & 1107 & 668 & 255 & 255 & 240 & 364 & 932 & 1369 & 2107 & 3185 & 3068 & 2861 \\
\hline 51 & 1506 & 1180 & 647 & 950 & 1449 & 1841 & 2192 & 3889 & 5359 & 5236 & 5691 & 6373 \\
\hline 52 & 1830 & 1015 & 1349 & 917 & 786 & 1870 & 2500 & 3996 & 4244 & 4809 & 4517 & 4694 \\
\hline 53 & 3460 & 2089 & 2053 & 1841 & 1609 & 3336 & 6446 & 6899 & 5557 & 7731 & 8500 & 10147 \\
\hline 54 & 3944 & 2298 & 1614 & 2143 & 2444 & 2833 & 3487 & 4545 & 6199 & 6186 & 8563 & 8295 \\
\hline 55 & 7362 & 6551 & 4006 & 3925 & 3243 & 5863 & 8226 & 8346 & 9397 & 11245 & 10703 & 10173 \\
\hline 56 & 3387 & 4820 & 5007 & 3284 & 4654 & 6573 & 4863 & 5993 & 7543 & 8735 & 9192 & 8456 \\
\hline 57 & 8126 & 7098 & 7480 & 7318 & 7506 & 6922 & 7891 & 8007 & 11717 & 10761 & 11740 & 12782 \\
\hline 58 & 4165 & 4456 & 4586 & 4437 & 4737 & 4269 & 5400 & 8055 & 7710 & 9190 & 8423 & 9914 \\
\hline 59 & 1009 & 77731 & 6755 & 7943 & 8161 & 9096 & 9636 & 10541 & 10634 & 11687 & 12881 & 12466 \\
\hline 60 & 7619 & 5859 & 5893 & 6516 & 5705 & 6481 & 6565 & 6563 & 7634 & 9308 & 8000 & 8595 \\
\hline 61 & 13516 & 12080 & 9008 & 7427 & 9092 & 9264 & 11759 & 12041 & 16781 & 15096 & 17390 & 18527 \\
\hline 62 & 7921 & 7685 & 8413 & 7230 & 7163 & 6493 & 8033 & 10150 & 6920 & 10923 & 13179 & 14065 \\
\hline 63 & 13655 & 12613 & 12754 & 13052 & 11400 & 12464 & 11082 & 12991 & 14903 & 17317 & 19026 & 19995 \\
\hline 64 & 8904 & 7924 & 8077 & 7010 & 6961 & 7187 & $74 \Delta .2$ & 6666 & 9129 & 11339 & 12323 & 12862 \\
\hline 65 & 13876 & 14120 & 13035 & 13984 & 14602 & 13191 & $12 \approx 76$ & 12772 & 16.264 & 18838 & 15461 & 13383 \\
\hline 66 & 9680 & 7652 & 8069 & 7579 & 7259 & 7084 & 6574 & 8107 & 9718 & 8483 & 7313 & 5622 \\
\hline 67 & 16864 & 16087 & 13937 & 12333 & 13456 & 11928 & 12566 & 13975 & 14451 & 9910 & 8466 & 4325 \\
\hline 68 & 10913 & 9619 & 7661 & 8530 & 8112 & 8544 & 8169 & 8942 & 7918 & 5279 & 2699 & 1797 \\
\hline 69 & 16088 & 13161 & 15425 & 15487 & 13789 & 13034 & 13562 & 12842 & 9755 & 4883 & 2771 & 1725 \\
\hline 70 & 6388 & 10244 & 9238 & 8982 & 9261 & 9171 & 7568 & 7636 & 5031 & 2088 & 435 & 453 \\
\hline 71 & 12326 & 13075 & 11276 & 12297 & 13481 & 11887 & 13097 & 8885 & 3515 & 1608 & 1093 & 415 \\
\hline 72 & 4820 & 6979 & 9094 & 7713 & 8291 & 8394 & 5374 & 5033 & 2391 & 419 & 234 & .nd \\
\hline 73 & 6705 & 10337 & 9394 & 11721 & 10380 & 10292 & 9228 & 5240 & 1379 & 895 & .nd & 110 \\
\hline 74 & 2334 & 5208 & 7163 & 6077 & 6674 & 6571 & 4149 & 1358 & 677 & .nd & 110 & .nd \\
\hline 75 & 2133 & 4239 & 8019 & 8725 & 6772 & 5589 & 4852 & 1944 & 729 & .nd & .nd & .nd \\
\hline 76 & 653 & 2246 & 3276 & 3196 & 3963 & 3011 & 1702 & 765 & 467 & 110 & .nd & .nd \\
\hline 77 & 1191 & 2919 & 3712 & 5287 & 3975 & 3311 & 2077 & 1118 & .nd & .nd & .nd & .nd \\
\hline 78 & 470 & 876 & 1663 & 2000 & 2227 & 1699 & 1086 & 321 & 110 & .nd & .nd & .nd \\
\hline 79 & 110 & 455 & 1631 & 1821 & 2461 & 1718 & 907 & 240 & .nd & .nd & .nd & .nd \\
\hline 80 & .nd & 350 & 547 & 1213 & 1034 & 787 & 203 & .nd & .nd & .nd & .nd & .nd \\
\hline 81 & 110 & .nd & 588 & 296 & 603 & 395 & 120 & 110 & .nd & .nd & .nd & .nd \\
\hline 82 & .nd & .nd & .nd & 349 & 469 & 360 & .nd & .nd & .nd & .nd & .nd & .nd \\
\hline 83 & .nd & 110 & .nd & 120 & .nd & .nd & 110 & .nd & .nd & .nd & .nd & .nd \\
\hline 85 & nd & .nd & 110 & nd & .nd & 110 & .nd & .nd & .nd & .nd & .nd & .nd \\
\hline 86 & .nd & .nd & .nd & 110 & 110 & .nd & .nd & .nd & .nd & .nd & .nd & .nd \\
\hline 87 & .nd & .nd & .nd & .nd & .nd & .nd & .nd & .nd & .nd & .nd & .nd & .nd \\
\hline 88 & .nd & .nd & .nd & .nd & .nd & .nd & .nd & .nd & .nd & .nd & .nd & .nd \\
\hline 89 & .nd & .nd & .nd & .nd & .nd & .nd & .nd & .nd & .nd & .nd & .nd & .nd \\
\hline
\end{tabular}

nd = no data available 
Table C9: Central Air Conditioner Raw Time-Temperature Matrix Standard Deviation of Load for all CEC Regions

\begin{tabular}{|c|c|c|c|c|c|c|c|c|c|c|c|c|}
\hline \multicolumn{2}{|c|}{ hour $\rightarrow 1$} & 2 & 3 & 4 & 5 & 6 & 7 & 8 & 9 & 10 & 11 & 12 \\
\hline 45 & 0.205 & 0.207 & 0.226 & 0.239 & 0.235 & 0.304 & 0.399 & 0.368 & 0.332 & 0.346 & 299 & \\
\hline 46 & 0.207 & 0.238 & 0.257 & 0.234 & 0.224 & 0.255 & 0.504 & & & & & \\
\hline 47 & 0.198 & 0.201 & 0.213 & 0.227 & 0.238 & 0.281 & 0.3 & & & & & 357 \\
\hline 48 & 0.179 & 0.197 & 0.189 & 0.2 & 0.1 & & & & & & & 354 \\
\hline 49 & 0.185 & 0.183 & 0.15 & 0.18 & 0.2 & & & & & & & .277 \\
\hline 50 & 0.166 & 0.15 & 0.1 & 0.1 & & & & & 0.288 & & & \\
\hline 51 & & 0.1 & & 0.1 & & 0.234 & 0.3 & 0.306 & 0.243 & 45 & 0.308 & .251 \\
\hline 52 & 0.1 & 0.1 & 0.1 & 0. & 0.183 & 0.183 & 0.3 & 0.278 & 0.232 & 28 & 0.223 & .231 \\
\hline 53 & 0.1 & 0. & & 0.156 & 0.168 & 0.206 & 0.2 & 0.291 & 0.240 & 0.266 & 0.234 & .222 \\
\hline 54 & 0.133 & 0.127 & 0.124 & 0.125 & 0.138 & 0.145 & 0.228 & 0.212 & 0.194 & 0.223 & 0.191 & .254 \\
\hline 55 & 0.119 & 0.118 & 0.122 & 0.123 & 0.154 & 0.149 & 0.207 & 0.191 & 0.200 & 0.176 & 0.244 & 0.174 \\
\hline 56 & 0.105 & 0.103 & 0.085 & 0.095 & 0.098 & 0.158 & 0.280 & 0.293 & 0.304 & 0.157 & 0.169 & .330 \\
\hline 57 & 0.088 & 0.094 & 0.090 & 0.089 & 0.210 & 0.272 & 0.317 & 0.160 & 0.180 & 0.212 & & .146 \\
\hline 58 & 0.078 & 0.099 & 0.212 & 0.25 & 0.183 & 0.226 & 0.1 & & 0.2 & & & .143 \\
\hline 59 & 0.259 & 0.262 & 0.233 & 0.2 & 0.2 & 0.23 & 0.2 & & 0.2 & & & .187 \\
\hline 60 & & 0.3 & 0.2 & 0.3 & 0.1 & 0.2 & 0.2 & & 0.1 & & & .305 \\
\hline 61 & & 0.2 & 0.2 & 0.1 & 0.3 & 0.27 & 0.2 & 0 & 0.380 & & & .239 \\
\hline 62 & 0.2( & 0.28 & 0.2 & 0.3 & 0.1 & 0.15 & & & 0.175 & & & .274 \\
\hline 63 & 0.27 & 0.3 & 0.2 & 0.1 & 0.2 & 0.211 & 0.2 & 0.2 & 0.2 & & & 130 \\
\hline 64 & 0.2 & 0.24 & 0.2 & 0.2 & 0.2 & 0.227 & 0.1 & 0.2 & 0.2 & & & 0.172 \\
\hline 65 & 0.3 & 0.26 & 0.290 & 0.2 & 0.201 & 0.210 & 0.2 & & 96 & 0.2 & & 0.199 \\
\hline 66 & 0.330 & 0.38 & 0.265 & 0.23 & 0.278 & 0.266 & 0.2 & & 0.273 & 86 & & .178 \\
\hline 67 & 0.470 & 0.383 & 0.355 & 0.356 & 0.303 & 0.293 & 0.309 & 0.317 & 0.294 & 0.354 & 0.270 & 0.256 \\
\hline 68 & 0.460 & 0.410 & 0.387 & 0.375 & 0.401 & 0.352 & 0.352 & 0.344 & 0.334 & 0.382 & 0.365 & 0.303 \\
\hline 69 & 0.550 & 0.549 & 0.500 & 0.450 & 0.398 & 0.360 & 0.401 & 0.429 & 0.401 & 0.410 & 0.420 & 0.391 \\
\hline 70 & 0.570 & 0.512 & 0.473 & 0.475 & 0.422 & 0.420 & 0.361 & 0.490 & 0.553 & 2.721 & 0.483 & 0.446 \\
\hline 71 & 0.634 & 0.579 & 0.534 & 0.509 & 0.475 & 0.454 & 0.454 & 0.491 & 0.476 & 0.468 & 0.502 & 0.525 \\
\hline 72 & 0.715 & 0.666 & 0.607 & 0.588 & 0.575 & 0.554 & 0.579 & 0.593 & 0.591 & 0.607 & 0.500 & 0.562 \\
\hline 73 & 0.788 & 0.718 & 0.711 & 0.597 & 0.555 & 0.602 & 0.611 & 0.671 & 0.635 & 0.623 & 0.607 & 0.667 \\
\hline 74 & 0.835 & 0.833 & 0.740 & 0.749 & 0.659 & 0.542 & 0.470 & 0.807 & 0.855 & 0.732 & 0.687 & 0.671 \\
\hline 75 & 0.918 & 0.868 & 0.810 & 0.741 & 0.857 & .nd & .nd &.$n d$ & 0.778 & 0.825 & 0.812 & 0.758 \\
\hline 76 & 1.013 & 0.964 & 0.714 & 0.812 & .nd & .nd & .nc & .nc & 1.040 & 0.892 & 0.896 & 0.914 \\
\hline 77 & 1.171 & 0.936 & 1.102 & .nd & .ne & .nd & .nc & .no & 1.040 & 1.154 & 1.006 & 1.067 \\
\hline 78 & 1.235 & 1.308 & .nd & .nd & .nc & .nd & .nc & .no & .nd & 1.228 & 1.111 & 1.172 \\
\hline 79 & 1.486 & 1.413 & .nd & .nd & .nd & .nd & .no & .no & .nd & 1.331 & 1.315 & 1.309 \\
\hline 80 & .nd & .nd & .nd & .nd & .nd & .nd & .no & .no & .nd & .nd & 1.413 & 1.446 \\
\hline 81 & .nd & .nd & .nd & .nd & .nd & .nd & .nc & .no & .nd & .nd & .nd & 1.622 \\
\hline 82 & .nd & .nd & .nd & .nd & .nd & .nd & no & .no & .nd & .nd & .nd & 1.517 \\
\hline 83 & .nd & .nd & .nd & .nd & .nd & .nd & .no & .nd & .nd & .nd & .nd & 1.676 \\
\hline 84 & .nd & .nd & .nd & .nd & .nd & .nd & .nc & .no & .nd & .nd & .nd & .nd \\
\hline 85 & .nd & .nd & .nd & .nd & .no & .nd & .nc & .nc & .nd & .nd & .nd & .nd \\
\hline 86 & .nd & .nd & .nd & .nd & .nd & no & .nc & .no & .no & .nd & .nd & .nd \\
\hline 87 & .nd & .nd & .nd & .nd & .no & nd & nd & .nd & no & .nd & .nd & .nd \\
\hline 88 & .no & .nd & .nd & no & nd & ndd & no & .nd & .nd & .nd & .nd & .nd \\
\hline 89 & & & & & 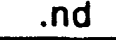 & 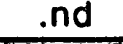 & 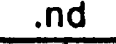 & . & .nd & .nd & .nd & .nd \\
\hline
\end{tabular}

.nd $=$ no data available 


\begin{tabular}{|c|c|c|c|c|c|c|c|c|c|c|c|c|}
\hline \multirow{2}{*}{\multicolumn{2}{|c|}{$\begin{array}{c}\text { Table } \\
\text { hour } \rightarrow 13\end{array}$}} & \multirow{2}{*}{$\begin{array}{cc}59 & c \\
5 & \\
1\end{array}$} & $\begin{array}{l}\text { Sont'd: C } \\
\text { Standard }\end{array}$ & \multirow{2}{*}{$\begin{array}{c}\text { Central } \\
\text { Devlat } \\
16\end{array}$} & \multirow{2}{*}{$\begin{array}{c}\text { Air C } \\
\text { ion of } \\
17\end{array}$} & \multirow{2}{*}{$\begin{array}{c}\text { Conditio } \\
\text { foad } \\
18\end{array}$} & \multirow{2}{*}{$\begin{array}{c}\underset{\text { ner }}{f} \\
19\end{array}$} & \multirow{2}{*}{$\begin{array}{rr}\text { Raw } & T \\
\text { all } & C \\
20\end{array}$} & \multicolumn{2}{|c|}{$\begin{array}{l}\text { ime-Temperatur } \\
\text { EC Regions }\end{array}$} & \multicolumn{2}{|c|}{ Matrix } \\
\hline & & & 15 & & & & & & 21 & 22 & 23 & 24 \\
\hline 45 & 0.359 & & & & & & & & & & & \\
\hline 46 & & 0.265 & 0.296 & & & .188 & & & & & 0.188 & \\
\hline 47 & & 0.2 & & & & & & & & & & \\
\hline 48 & 0.225 & 0.2 & 0.353 & 0.225 & 0.336 & & 0.327 & 70.240 & & 0.189 & 0.198 & .192 \\
\hline 49 & 0.284 & 0.222 & 0.279 & 0.305 & 0.229 & 0.268 & 0.271 & 0.224 & 0.209 & 0.191 & 0.218 & 0.187 \\
\hline 50 & 13 & 0.2 & 0.256 & 0.2 & 0.2 & 0.208 & 0.2 & 40.215 & & 0.187 & 99 & .175 \\
\hline 51 & 0.266 & 0.260 & 0.191 & 0.237 & 0.260 & 0.2 & 0.31 & 30.206 & 0.1 & 0.200 & 0.182 & .174 \\
\hline 52 & 0.241 & 0.266 & 0.220 & 0.187 & 0.207 & 0.237 & 0.236 & 0.210 & 0.200 & 0.194 & 0.174 & 0.150 \\
\hline 53 & 0.216 & 0.207 & 0.252 & 0.244 & 0.270 & 0.236 & 0.192 & 0.190 & 0.202 & 0.175 & 0.172 & \\
\hline 54 & & 0.204 & 0.157 & 0.193 & 0.188 & 0.2 & 0.198 & 0.179 & 0.200 & 0.156 & & \\
\hline 55 & 0.2 & 0.210 & 0.209 & 0.16 & 0.1 & & 0.1 & 0.195 & & & & 0.1 \\
\hline 56 & 0.1 & & & 0.2 & 0.2 & & 0.2 & 0.1 & & & & \\
\hline 57 & 0.1 & 0.1 & 0.14 & 0.1 & 0.1 & & & & & & & \\
\hline 58 & 0.32 & 0.134 & 0.177 & 0.1 & 0.1 & 9 & 0.1 & 50.1 & & & & \\
\hline 59 & 0.128 & 0.248 & 0.155 & 0.1 & 0.1 & 0.2 & 0.1 & 0.142 & & & & \\
\hline 60 & .115 & 0.129 & 0.312 & 0.323 & 0.310 & 0.1 & 0.2 & 0.284 & & & & \\
\hline 61 & 0.239 & 0.139 & 0.129 & 0.121 & 0.145 & .157 & 0.14 & 0.141 & 0.175 & & & \\
\hline 62 & & 0.181 & 0.118 & 0.106 & 0.129 & .149 & 0.155 & 0.291 & 0.290 & 0.3 & 0.364 & \\
\hline 63 & & & 0.246 & 133 & 0.145 & 0.264 & 0.28 & 0.306 & 0.397 & 0.285 & 0.247 & 0.2 \\
\hline 64 & & & & & & & 0.3 & 0.361 & 0.3 & 0.3 & 0.376 & \\
\hline 65 & & & 0.1 & 0.2 & 0.2 & 6 & 0.2 & 0.3 & & 0.407 & 0.383 & \\
\hline 66 & & & 0.1 & 0.2 & 0.2 & & 0.4 & 0.372 & & 0.4 & 0.4 & \\
\hline 67 & & & 0.2 & 0 & 0.3 & & 0.4 & 70.4 & & & 0.572 & 0.449 \\
\hline 68 & & & & & & & & 40.5 & & & 79 & 0.5 \\
\hline 69 & & & & & & & & & & & & \\
\hline 70 & 0.464 & 0.379 & & & & & & $\begin{array}{ll}30.7 \\
0.7\end{array}$ & & & 24 & 0. \\
\hline 71 & 0.500 & 0.433 & 0.443 & 0 & & & & & & & & \\
\hline 72 & 0.513 & 0.538 & 0.622 & 0.630 & 0 & & & & & & & \\
\hline 73 & 0.630 & 0.694 & 0.670 & 0.783 & 0.875 & 0.976 & 1.0 & 21.1 & & & & \\
\hline 74 & 0.736 & 0.694 & 0.807 & 0 & 1.00 & 17 & 1.204 & 1.044 & 1.0 & 1.089 & & \\
\hline 75 & 0. & 0.841 & 0.857 & & 1.0 & & 1.2 & 31.172 & & 1.138 & 1.113 & 0.578 \\
\hline 76 & 0. & 0.97 & 0.983 & 5 & 1.193 & 1.2 & 1.2 & 1.250 & 1.2 & 1.302 & 1.231 & 1.120 \\
\hline 77 & 1.023 & 1.078 & 1.222 & 1.246 & 1.254 & 1.332 & 1.450 & 1.404 & 1.365 & 1.417 & 1.311 & 1.182 \\
\hline 78 & & 1.206 & 1.231 & 1.34 & 1.449 & 1.505 & 1.557 & 71.478 & & & 1.404 & 1.8 \\
\hline 79 & & 1.290 & 1.394 & 1.45 & 1.5 & 1.637 & 1.633 & 31.593 & 1.586 & 1.606 & 1.469 & \\
\hline 80 & & 1.467 & 1.500 & 16 & 1.707 & 1.708 & 1.739 & 91.713 & 1.657 & 1.671 & 1.601 & 1.557 \\
\hline 81 & & 1.618 & 1.595 & 1.703 & 1.782 & 1.862 & 1.877 & 71.811 & 1.769 & 1.767 & 1.770 & .nd \\
\hline 82 & & 1.744 & 1.772 & 18 & 1.868 & 1.914 & 1.9 & 1.900 & 1.842 & 1.854 & 1.622 & \\
\hline 83 & & & 1.907 & 1.923 & 1.965 & 2.016 & 2.025 & 51.962 & 1.932 & 1.889 & & .nd \\
\hline 84 & 1.883 & 1.965 & 56 & & & & 21 & 2.055 & 1.980 &.$n$ &.$n$ & .nd \\
\hline 85 & 1.899 & 2.043 & 2.104 & 2.107 & 2.143 & 2.156 & 2.155 & 52.064 & 2.062 &.$n$ & & .nd \\
\hline 86 & .nd & 1.934 & 2.153 & 2.263 & 2.193 & 2.205 & 2.192 & 2.194 & .nd & .nd & .nd & .nd \\
\hline 87 & &.$n c$ &. ne & & & 2.257 & 2.214 & 2.152 & .nd & .nd & .nd & .nd \\
\hline 88 &.$n c$ & .no &.$n$ & 2.160 & 2.2 & & 1.9 & .nd &.$n c$ & .nd & .nd & .nd \\
\hline 89 & & .na & .nd & $\cdots$ & 1.972 & 2.427 & $2 .-2$ & .nd & .nd & .nd & .nd & .nd \\
\hline
\end{tabular}

.nd = no data avalable 


\begin{tabular}{|c|c|c|c|c|c|c|c|c|c|c|c|c|}
\hline \multirow{2}{*}{\multicolumn{2}{|c|}{ hour $\rightarrow 1$}} & \multicolumn{2}{|c|}{$\begin{array}{l}\text { C10: Centra } \\
\text { Standard }\end{array}$} & $\begin{array}{l}\text { al Air } \\
\text { Devia }\end{array}$ & \multicolumn{2}{|c|}{$\begin{array}{l}\text { Conditioner } \\
\text { ation of Loa }\end{array}$} & Raw & \multicolumn{3}{|c|}{$\begin{array}{l}\text { Time-Temperature } \\
\text { CEC Region } 2\end{array}$} & \multicolumn{2}{|l|}{ Matrix } \\
\hline & & 2 & 3 & 4 & 5 & 6 & 7 & 8 & 9 & 10 & 11 & 12 \\
\hline 45 & 0.109 & 0.153 & 0.136 & 0.136 & 0.178 & 0.161 & 0.209 & 0.242 & 0.236 & 0.199 & 0.264 & 0.227 \\
\hline 46 & 0.165 & 0.132 & 0.184 & 0.080 & 0.161 & 0.177 & 0.283 & 0.298 & 0.215 & 0.270 & 0.257 & 0.325 \\
\hline 47 & 0.113 & 0.099 & 0.162 & 0.191 & 0.219 & 0.204 & 0.261 & 0.233 & 0.203 & 0.252 & 0.184 & 0.285 \\
\hline 48 & 0.103 & 0.120 & 0.126 & 0.162 & 0.107 & 0.101 & 0.181 & 0.215 & 0.205 & 0.142 & 0.244 & 0.170 \\
\hline 49 & 0.138 & 0.151 & 0.135 & 0.133 & 0.134 & 0.167 & 0.150 & 0.188 & 0.201 & 0.223 & 0.171 & 0.182 \\
\hline 50 & 0.112 & 0.126 & 0.112 & 0.078 & 0.106 & 0.113 & 0.134 & 0.172 & 0.161 & 0.296 & 0.177 & 0.263 \\
\hline 51 & 0.089 & 0.097 & 0.085 & 0.079 & 0.106 & 0.136 & 0.131 & 0.177 & 0.166 & 0.215 & 0.185 & 0.135 \\
\hline 52 & 0.099 & 0.106 & 0.090 & 0.102 & 0.129 & 0.109 & 0.183 & 0.178 & 0.165 & 0.156 & 0.210 & 0.189 \\
\hline 53 & 0.140 & 0.170 & 0.140 & 0.201 & 0.219 & 0.153 & 0.204 & 0.226 & 0.166 & 0.151 & 0.143 & 0.215 \\
\hline 54 & 0.054 & 0.066 & 0.074 & 0.062 & 0.071 & 0.062 & 0.117 & 0.130 & 0.126 & 0.133 & 0.138 & 0.212 \\
\hline 55 & 0.054 & 0.080 & 0.066 & 0.071 & 0.094 & 0.095 & 0.100 & 0.139 & 0.150 & 0.119 & 0.458 & 0.189 \\
\hline 56 & 0.061 & 0.043 & 0.036 & 0.057 & 0.064 & 0.050 & 0.081 & 0.092 & 0.123 & 0.122 & 0.106 & 0.687 \\
\hline 57 & 0.048 & 0.071 & 0.069 & 0.056 & 0.191 & 0.372 & 0.380 & 0.108 & 0.134 & 0.096 & 0.124 & 0.151 \\
\hline 58 & 0.037 & 0.094 & 0.084 & 0.093 & 0.384 & 0.070 & 0.215 & 0.607 & 0.495 & 0.639 & 0.096 & 0.144 \\
\hline 59 & 0.356 & 0.259 & 0.395 & 0.419 & 0.214 & 0.191 & 0.075 & 0.083 & 0.072 & 0.097 & 0.492 & 0.086 \\
\hline 60 & 0.512 & 0.604 & 0.300 & 0.148 & 0.219 & 0.324 & 0.360 & 0.097 & 0.097 & 0.058 & 0.062 & 0.578 \\
\hline 61 & 0.361 & 0.294 & 0.284 & 0.288 & 0.231 & 0.123 & 0.127 & 0.335 & 0.526 & 0.086 & 0.072 & 0.089 \\
\hline 62 & 0.319 & 0.146 & 0.144 & 0.165 & 0.156 & 0.123 & 0.147 & 0.143 & 0.157 & 0.087 & 0.090 & 0.079 \\
\hline 63 & 0.258 & 0.199 & 0.181 & 0.155 & 0.129 & 0.188 & 0.213 & 0.200 & 0.337 & 0.473 & 0.076 & 0.079 \\
\hline 64 & 0.341 & 0.272 & 0.233 & 0.238 & 0.296 & 0.232 & 0.200 & 0.205 & 0.228 & 0.192 & 0.113 & 0.066 \\
\hline 65 & 0.386 & 0.322 & 0.335 & 0.293 & 0.273 & 0.375 & 0.391 & 0.245 & 0.213 & 0.251 & 0.227 & 0.091 \\
\hline 66 & 0.470 & 0.412 & 0.403 & 0.369 & 0.533 & 0.283 & 0.231 & 0.249 & 0.372 & 0.285 & 0.352 & 0.098 \\
\hline 67 & 0.584 & 0.533 & 0.405 & 0.513 & 0.360 & 0.251 & 0.689 & 0.608 & 0.368 & 0.358 & 0.216 & 0.115 \\
\hline 68 & 0.678 & 0.562 & 0.539 & 0.747 & 0.381 & 1.257 & 0.252 & 0.256 & 0.307 & 0.379 & 0.235 & 0.181 \\
\hline 69 & 0.826 & 1.073 & 1.266 & 1.207 & 1.240 & 0.158 & 1.519 & 0.723 & 0.670 & 0.501 & 0.399 & 0.259 \\
\hline 70 & 0.691 & 1.187 & 0.543 & 0.246 & .nd & .nd & .nd & .nd & 0.633 & 0.507 & 0.522 & 0.249 \\
\hline 71 & 1.442 & 0.831 & 0.310 & .nd & .nd & 1.244 & .nd & .nd & 0.441 & 0.557 & 0.717 & 0.430 \\
\hline 72 & 1.054 & .nd & .nd & .nd & 1.782 & .nd & .nd & .nd & 0.694 & 0.669 & 0.557 & 0.469 \\
\hline 73 & 0.706 & .nd & .nd & .nd & .nd & .nd & .nd & .nd & 1.108 & 0.637 & 0.661 & 0.817 \\
\hline 74 & .nd & .nd & .nd & .nd & .nd & .nd & .nd & .nd & .nd & .nd & 0.738 & 0.700 \\
\hline 75 & .nd & .nd & .nd & .nd & .nd & .nd & .nd & .nd & .nd & 0.952 & 0.954 & 0.884 \\
\hline 76 & .nd & .nd & .nd & .nd & .nd & .nd & .nd & .nd & .nd & 0.796 & 1.025 & 1.138 \\
\hline 77 & .nd & .nd & .nd & .nd & .nd & .nd & .nd & .nd & .nd & .nd & 1.314 & 1.023 \\
\hline 78 & .nd & .nd & .nd & .nd & .nd & .nd & .nd & .nd & .nd & .nd & 1.295 & 1.176 \\
\hline 79 & .nd & .nd & .nd & .nd & .nd & .nd & .nd & .nd & .nd & .nd & .nd & 1.400 \\
\hline 80 & .nd & .nd & .nd & .nd & .nd & .nd & .nd & .nd & .nd & .nd & .nd & .nd \\
\hline 81 & .nd & .nd & .nd & .nd & .nd & .nd & .nd & .nd & .nd & .nd & .nd & .nd \\
\hline 82 & .nd & .nd & .nd & .nd & .nd & .nd & .nd & .nd & .nd & .nd & .nd & .nd \\
\hline 83 & .nd & .nd & .nd & .nd & .nd & .nd & .nd & .nd & .nd & .nd & .nd & .nd \\
\hline 84 & .nd & .nd & .nd & .nd & .nd & .nd & .nd & .nd & .nd & .nd & .nd & .nd \\
\hline 85 & .nd & .nd & .nd & .nd & .nd & .nd & .nd & .nd & .nd & .nd & .nd & .nd \\
\hline 86 & .nd & .nd & .nd & .nd & .nd & .nd & .nd & .nd & .nd & .nd & .nd & .nd \\
\hline 87 & .nd & .nd & .nd & .nd & .nd & .nd & .nd & .nd & .nd & .nd & .nd & .nd \\
\hline 88 & .nd & .nd & .nd & .nd & .nd & .nd & .nd & .nd & .nd & .nd & .nd & .nd \\
\hline 89 & .nd & .nd & .nd & .nd & .nd & .nd & .nd & .nd & .nd & .nd & .nd & .nd \\
\hline
\end{tabular}

.nd = no data avalable 


\begin{tabular}{|c|c|c|c|c|c|c|c|c|c|c|c|c|}
\hline \multirow{2}{*}{\multicolumn{2}{|c|}{$\begin{array}{l}\text { Table } \\
\text { hour } \rightarrow 13\end{array}$}} & \multicolumn{2}{|c|}{$\begin{array}{l}10 \text { colli'd: C } \\
\text { Standard }\end{array}$} & \multirow{2}{*}{$\begin{array}{c}\text { Dentral } \\
16\end{array}$} & \multirow{2}{*}{$\begin{array}{r}\text { Air } \\
\text { ation } \\
17\end{array}$} & \multirow{2}{*}{\multicolumn{2}{|c|}{$\begin{array}{c}\text { Conditioner } R \\
\text { of Load for } \\
\begin{array}{cc}18 & 19\end{array}\end{array}$}} & \multirow{2}{*}{$\begin{array}{c}\text { Raw TI } \\
\text { CEC } \\
20\end{array}$} & \multirow{2}{*}{\multicolumn{2}{|c|}{$\begin{array}{l}\text { Ime-Temperatur } \\
\text { Region } 2 \\
21 \quad 22\end{array}$}} & \multicolumn{2}{|c|}{ Matrix } \\
\hline & & 14 & 15 & & & & & & & & 23 & 24 \\
\hline 45 & 0.365 & 0.355 & 0.335 & 0.418 & 0.298 & 0.261 & 0.213 & 0.263 & 0.284 & 0.235 & 0.126 & 0.213 \\
\hline 46 & 0.166 & 0.304 & 0.339 & 0.251 & 0.228 & 0.291 & 0.165 & 0.296 & 0.200 & 0.189 & 0.141 & 0.121 \\
\hline 47 & 0.293 & 0.220 & 0.184 & 0.229 & 0.282 & 0.233 & 0.296 & 0.239 & 0.183 & 0.168 & 0.174 & 0.201 \\
\hline 48 & 0.304 & 0.317 & 0.227 & 0.196 & 0.289 & 0.161 & 0.225 & 0.230 & 0.196 & 0.135 & 0.116 & 0.091 \\
\hline 49 & 0.182 & 0.206 & 0.295 & 0.286 & 0.157 & 0.214 & 0.171 & 0.171 & 0.136 & 0.193 & 0.168 & 0.165 \\
\hline 50 & 0.269 & 0.150 & 0.211 & 0.204 & 0.241 & 0.159 & 0.155 & 0.157 & 0.182 & 0.103 & 0.186 & 0.148 \\
\hline 51 & 0.170 & 0.208 & 0.233 & 0.127 & 0.214 & 0.179 & 0.220 & 0.154 & 0.176 & 0.182 & 0.123 & 34 \\
\hline 52 & 0.211 & 0.216 & 0.198 & 0.158 & 0.149 & 0.150 & 0.177 & 0.132 & 0.189 & 0.153 & 0.174 & 69 \\
\hline 53 & 0.202 & 0.176 & 0.123 & 0.159 & 0.128 & 0.183 & 0.149 & 0.162 & 0.176 & 0.196 & 0.179 & 97 \\
\hline 54 & 0.136 & 0.237 & 0.133 & 0.146 & 0.119 & 0.116 & 0.166 & 0.180 & 0.096 & 0.115 & 0.135 & 0.113 \\
\hline 55 & 0.228 & 0.214 & 0.234 & 0.136 & 0.128 & 0.133 & 0.120 & 0.139 & 0.134 & 0.107 & 0.085 & 0.057 \\
\hline 56 & 0.106 & 0.116 & 0.207 & 0.125 & 0.116 & 0.148 & 0.196 & 0.130 & 0.120 & 0.112 & 0.081 & 0.072 \\
\hline 57 & 0.100 & 0.107 & 0.111 & 0.132 & 0.113 & 0.149 & 0.125 & 0.112 & 0.113 & 0.093 & 0.058 & 0.085 \\
\hline 58 & 0.730 & 0.151 & 0.077 & 0.129 & 0.138 & 0.100 & 0.109 & 0.069 & 0.082 & 0.049 & 0.111 & 0.081 \\
\hline 59 & 0.141 & 0.561 & 0.105 & 0.109 & 0.101 & 0.527 & 0.114 & 0.096 & 0.487 & 0.137 & 0.081 & 0.398 \\
\hline 60 & 0.124 & 0.161 & 0.721 & 0.907 & 0.763 & 0.079 & 0.660 & 0.588 & 0.075 & 0.518 & 0.538 & 0.122 \\
\hline 61 & 0.493 & 0.077 & 0.081 & 0.105 & 0.068 & 0.113 & 0.071 & 0.080 & 0.077 & 0.144 & 0.150 & 0.470 \\
\hline 62 & 0.089 & 0.114 & 0.090 & 0.099 & 0.128 & 0.065 & 0.088 & 0.714 & 0.147 & 0.597 & 0.583 & \\
\hline 63 & 0.066 & 0.397 & 0.407 & 0.071 & 0.062 & 0.591 & 0.584 & 0.10 & 0.6 & & 0.280 & 0. \\
\hline 64 & 0.057 & 0.091 & 0.059 & 0.061 & 0.591 & 0.092 & 0.097 & 0.136 & 0.2 & 0.227 & 0.492 & 0.332 \\
\hline 65 & 0.100 & 0.078 & 0.087 & 0.438 & 0.075 & 0.056 & 0.104 & 0.147 & 0.2 & 0.338 & 0.432 & 0.426 \\
\hline 66 & 0.117 & 0.129 & 0.102 & 0.165 & 0.086 & ; 0.133 & 0.214 & 0.179 & 0.343 & 0.505 & 0.487 & 0.528 \\
\hline 67 & 0.158 & 0.121 & 0.084 & 0.079 & 0.197 & 0.210 & 0.209 & 0.294 & 0.3 & 0.564 & 0.629 & 0.627 \\
\hline 68 & 0.183 & 0.192 & 0.129 & 0.197 & 0.2 & 0.203 & 0.284 & 0.5 & 0.5 & 0.652 & 0.711 & 0. \\
\hline 69 & 0.162 & 0.167 & 0.221 & & 0.2 & 0.2 & 0.2 & 0.5 & & & 94 & 0.867 \\
\hline 70 & 0.281 & 0.264 & 0.289 & 0.270 & 0.295 & 0.313 & 0.390 & 0.482 & 0.679 & 0.793 & 0.960 & 1.116 \\
\hline 71 & 0.313 & 0.288 & 0.316 & 0.336 & 0.364 & 0.425 & 0.556 & 0.757 & 0.825 & 0.980 & 1.048 & 0.879 \\
\hline 72 & 0.357 & 0.388 & 0.347 & 0.35 & 0.423 & $\begin{array}{ll}3 & 0.399\end{array}$ & 0.793 & 0.7 & 0.937 & 1.078 & 1.057 & 1.428 \\
\hline 73 & 0.459 & 0.518 & 0.512 & 0.5 & 0.598 & 30.763 & 0.933 & 0.9 & 1.082 & 1.157 & 1.246 & 1.924 \\
\hline 74 & 0.754 & 0.535 & 0.602 & 0.689 & 0.774 & 0.827 & 0.951 & 1.057 & 1.135 & 1.267 & 1.176 & .nd \\
\hline 75 & 0.840 & 0.734 & 0.716 & 0.8 & 0.910 & 1.047 & 1.086 & 1.169 & 1.263 & 1.334 & 1.831 & .nd \\
\hline 76 & 0.960 & 0.862 & 0.948 & 0.893 & 1.020 & 1.1 & 1.200 & 1.276 & 1.333 & 1.4 & 2.539 & 0.981 \\
\hline 77 & 1.035 & 1.068 & 1.012 & 1.117 & 1.264 & 1.318 & 1.472 & 1.377 & 1.446 & 1.513 & .nd & .nd \\
\hline 78 & 1.253 & 1.197 & 1.201 & 1.307 & 1.386 & 1.504 & 1.459 & 1.512 & 1.562 & 1.896 & .nd & .nd \\
\hline 79 & 1.558 & 1.391 & 1.345 & 1.433 & 1.554 & 1.621 & 1.621 & 1.623 & 1.576 & 1.335 & .nd & .nd \\
\hline 80 & 1.465 & 1.500 & 1.580 & 1.534 & 1.669 & 1.676 & 1.726 & 1.731 & 1.655 & .nd & .nd & .nd \\
\hline 81 & 1.523 & 1.613 & 1.599 & 1.707 & 1.769 & 1.802 & 1.837 & 1.751 & 1.726 & .nd & .nd & .nd \\
\hline 82 & 1.629 & 1.836 & 1.744 & 1.777 & 1.805 & 1.885 & 1.937 & 1.802 & 1.592 & .nd & .nd & .nd \\
\hline 83 & .nd & 1.850 & 1.824 & 1.869 & 1.924 & 1.972 & 1.909 & 1.813 & 1.672 & .nd & .nd & .nd \\
\hline 84 & .nd & 1.903 & 1.879 & 1.930 & 2.004 & 2.002 & 2.001 & 1.929 & 1.766 & .nd & .nd & .nd \\
\hline 85 & .nd & .nd & 1.985 & 1.956 & 1.994 & 2.028 & 2.033 & 1.753 & .nd & .nd & .nd & .nd \\
\hline 86 & .nd & .nd & .nd & 2.062 & 2.109 & 2.046 & 1.879 & 1.852 & .nd & .nd & .nd & .nd \\
\hline 87 & .nd & .nd & .nd & 1.888 & 2.064 & 2.020 & 1.979 & 1.852 & .nd & .nd & .nd & .nd \\
\hline 88 & .nd & .nd & .nd & .nd & 1.811 & 1.985 & 1.950 & .nd & .nd & .nd & .nd & .nd \\
\hline 89 & .nd & .nd & .nd & .nd & 1.972 & .nd & .nd & .nd & .nd & .nd & .nd & .nd \\
\hline
\end{tabular}

.nd = no data available 
Table C11: Central Alr Conditioner Raw Time-Temperature Matrix Standard Deviation of Load for CEC Region 3

\begin{tabular}{|c|c|c|c|c|c|c|c|c|c|c|c|c|}
\hline \multicolumn{2}{|c|}{ hour $\rightarrow 1$} & 2 & 3 & 4 & 5 & 6 & 7 & 8 & 9 & 10 & 11 & 12 \\
\hline 45 & 0.204 & 0.177 & 0.202 & 0.198 & 0.142 & 0.323 & 0.504 & 0.396 & 0.356 & 0.391 & 0.320 & 0.338 \\
\hline 46 & 0.165 & 0.225 & 0.223 & 0.215 & 0.181 & 0.229 & 0.700 & 0.517 & 0.407 & 0.309 & 0.376 & 0.310 \\
\hline 47 & 0.137 & 0.168 & 0.182 & 0.171 & 0.205 & 0.304 & 0.456 & 0.424 & 0.317 & 0.385 & 0.380 & 0.424 \\
\hline 48 & 0.109 & 0.160 & 0.145 & 0.165 & 0.123 & 0.320 & 0.413 & 0.442 & 0.482 & 0.311 & 0.325 & 0.421 \\
\hline 49 & 0.144 & 0.117 & 0.124 & 0.126 & 0.209 & 0.266 & 0.389 & 0.354 & 0.327 & 0.258 & 0.301 & 0.312 \\
\hline 50 & 0.112 & 0.155 & 0.087 & 0.164 & 0.166 & 0.329 & 0.376 & 0.410 & 0.355 & 0.418 & 0.173 & 0.450 \\
\hline 51 & 0.125 & 0.085 & 0.144 & 0.139 & 0.143 & 0.284 & 0.544 & 0.388 & 0.279 & 0.242 & 0.381 & 0.285 \\
\hline 52 & 0.085 & 0.098 & 0.089 & 0.098 & 0.175 & 0.179 & 0.480 & 0.355 & 0.253 & 0.254 & 0.221 & 0.258 \\
\hline 53 & 0.089 & 0.082 & 0.082 & 0.094 & 0.119 & 0.244 & 0.343 & 0.377 & 0.296 & 0.348 & 0.258 & 0.242 \\
\hline 54 & 0.109 & 0.079 & 0.053 & 0.072 & 0.134 & 0.127 & 0.297 & 0.241 & 0.223 & 0.279 & 0.192 & 0.303 \\
\hline 55 & 0.091 & 0.065 & 0.106 & 0.093 & 0.176 & 0.175 & 0.289 & 0.185 & 0.252 & 0.191 & 0.176 & 0.163 \\
\hline 56 & 0.076 & 0.073 & 0.056 & 0.059 & 0.054 & 0.217 & 0.332 & 0.186 & 0.129 & 0.188 & 0.184 & 0.122 \\
\hline 57 & 0.078 & 0.073 & 0.056 & 0.074 & 0.071 & 0.152 & 0.370 & 0.193 & 0.155 & 0.159 & 0.152 & 0.123 \\
\hline 58 & 0.049 & 0.040 & 0.084 & 0.065 & 0.080 & 0.387 & 0.151 & 0.313 & 0.094 & 0.156 & 0.187 & 0.127 \\
\hline 59 & 0.084 & 0.083 & 0.071 & 0.093 & 0.319 & 0.156 & 0.321 & 0.292 & 0.097 & 0.116 & 0.104 & 0.095 \\
\hline 60 & 0.063 & 0.060 & 0.060 & 0.348 & 0.076 & 0.274 & 0.263 & 0.279 & 0.118 & 0.152 & 0.110 & 0.097 \\
\hline 61 & 0.056 & 0.074 & 0.330 & 0.152 & 0.255 & 0.080 & 0.127 & 0.113 & 0.389 & 0.101 & 0.128 & 0.109 \\
\hline 62 & 0.100 & 0.405 & 0.231 & 0.245 & 0.112 & 0.150 & 0.107 & 0.138 & 0.074 & 0.062 & 0.093 & 0.175 \\
\hline 63 & 0.385 & 0.191 & 0.130 & 0.153 & 0.247 & 0.231 & 0.251 & 0.172 & 0.253 & 0.314 & 0.109 & 0.114 \\
\hline 64 & 0.108 & 0.181 & 0.260 & 0.280 & 0.126 & 0.130 & 0.145 & 0.323 & 0.135 & 0.360 & 0.054 & 0.146 \\
\hline 65 & 0.229 & 0.220 & 0.243 & 0.200 & 0.190 & 0.190 & 0.194 & 0.213 & 0.312 & 0.224 & 0.100 & 0.141 \\
\hline 66 & 0.224 & 0.308 & 0.171 & 0.218 & 0.227 & 0.245 & 0.214 & 0.291 & 0.207 & 0.170 & 0.398 & 0.118 \\
\hline 67 & 0.368 & 0.315 & 0.330 & 0.314 & 0.280 & 0.283 & 0.213 & 0.272 & 0.239 & 0.284 & 0.214 & 0.115 \\
\hline 68 & 0.327 & 0.369 & 0.350 & 0.346 & 0.415 & 0.238 & 0.359 & 0.299 & 0.287 & 0.269 & 0.209 & 0.179 \\
\hline 69 & 0.421 & 0.438 & 0.391 & 0.369 & 0.343 & 0.368 & 0.364 & 0.395 & 0.324 & 0.281 & 0.253 & 0.357 \\
\hline 70 & 0.541 & 0.478 & 0.457 & 0.473 & 0.422 & 0.390 & 0.355 & 0.435 & 0.514 & 0.330 & 0.324 & 0.301 \\
\hline 71 & 0.547 & 0.566 & 0.529 & 0.503 & 0.442 & 0.396 & 0.447 & 0.454 & 0.449 & 0.361 & 0.365 & 0.292 \\
\hline 72 & 0.664 & 0.652 & 0.609 & 0.578 & 0.522 & 0.561 & 0.494 & 0.549 & 0.554 & 0.523 & 0.398 & 0.411 \\
\hline 73 & 0.770 & 0.717 & 0.705 & 0.597 & 0.537 & 0.566 & 0.543 & 0.630 & 0.580 & 0.562 & 0.464 & 0.488 \\
\hline 74 & 0.822 & 0.828 & 0.734 & 0.725 & 0.672 & 0.545 & 0.489 & 0.781 & 0.799 & 0.694 & 0.593 & 0.574 \\
\hline 75 & 0.888 & 0.853 & 0.792 & 0.720 & 0.710 & .nd & .nd & .nd & 0.780 & 0.771 & 0.741 & 0.658 \\
\hline 76 & 0.986 & 0.945 & 0.738 & 0.699 & .nd & .nd & .nd & .nd & 1.000 & 0.854 & 0.858 & 0.794 \\
\hline 77 & 1.136 & 0.900 & 1.030 & .nd & .nd & .nd & .nd & .nd & 1.075 & 1.109 & 0.965 & 0.963 \\
\hline 78 & 1.184 & 1.255 & .nd & .nd & .nd & .nd & .nd & .nd & .nd & 1.2 .29 & 1.004 & 1.130 \\
\hline 79 & 1.426 & 1.192 & .nd & .nd & .nd & .nd & .nd & .nd & .nd & 1.196 & 1.256 & 1.233 \\
\hline 80 & .nd & .nd & .nd & .nd & .nd & .nd & .nd & .nd & .nd & .nd & 1.364 & 1.368 \\
\hline 81 & .nd & .nd & .nd & .nd & .nd & .nd & .nd & .nd & .nd & .nd & .nd & 1.522 \\
\hline 82 & .nd & .nd & .nd & .nd & .nd & .nd & .nd & .nd & .nd & .nd & .nd & 1.520 \\
\hline 83 & .nd & .nd & .nd & .nd & .nd & .nd & .nd & .nd & .nd & .nd & .nd & 1.655 \\
\hline 84 & .nd & .nd & .nd & .nd & .nd & .nd & .nd & .nd & .nd & .nd & .nd & .nd \\
\hline 85 & .nd & .nd & .nd & .nd & .nd & .nd & .nd & .nd & .nd & .nd & .nd & .nd \\
\hline 86 & .nd & .nd & .nd & .nd & .nd & .nd & .nd & .nd & .nd & .nd & .nd & .nd \\
\hline 87 & .nd & .nd & .nd & .nd & .nd & .nd & .nd & .nd & .nd & .nd & .nd & .nd \\
\hline 88 & .nd & .nd & .nd & .nd & .nd & .nd & .nd & .nd & .nd & .nd & .nd & .nd \\
\hline 89 & .nd & .nd & .nd & .nd & .nd & .nd & .nd & .nd & .nd & .nd & .nd & .nd \\
\hline
\end{tabular}

.nd = no data avaiable 


\begin{tabular}{|c|c|c|c|c|c|c|c|c|c|c|c|c|}
\hline \multirow{2}{*}{\multicolumn{2}{|c|}{$\begin{array}{l}\text { Table C11 } \\
\text { hour } \rightarrow 13\end{array}$}} & \multicolumn{2}{|c|}{$\begin{array}{l}\text { cont'd: C } \\
\text { Standarc }\end{array}$} & \multirow{2}{*}{$\begin{array}{l}\text { Dentral } \\
16\end{array}$} & \multirow{2}{*}{$\begin{array}{l}\text { Air } \\
\text { atton } \\
17\end{array}$} & \multirow{2}{*}{\multicolumn{2}{|c|}{$\begin{array}{c}\text { Conditioner } R \\
\text { of Load for } \\
18 \quad 19\end{array}$}} & \multirow{2}{*}{$\begin{array}{c}\text { Raw T } \\
\text { CEC } \\
20\end{array}$} & \multirow{2}{*}{\multicolumn{2}{|c|}{$\begin{array}{c}\text { Time-Temperatur } \\
\begin{array}{cc}\text { Region } & 3 \\
21 & 22\end{array}\end{array}$}} & \multicolumn{2}{|c|}{ Matrix } \\
\hline & & 14 & 15 & & & & & & & & 23 & 24 \\
\hline & 0.379 & 0.186 & 0.378 & 0.138 & 0.363 & 0.328 & 0.327 & 0.398 & 30.290 & 0.241 & 0.216 & 0.184 \\
\hline 46 & 0.363 & 0.262 & 0.295 & 0.384 & 0.160 & 0.146 & 0.291 & 0.208 & 0.328 & 0.193 & 0.158 & 0.170 \\
\hline 47 & 0.324 & 0.321 & 0.185 & 0.231 & 0.241 & 0.379 & 0.346 & 0.217 & 0.152 & 0.164 & 0.128 & 0.120 \\
\hline 48 & 0.192 & 0.279 & 0.424 & 0.245 & 0.387 & 0.283 & 0.381 & 0.239 & 0.192 & 0.191 & 0.180 & 0.149 \\
\hline 49 & 0.327 & 0.195 & 0.280 & 0.328 & 0.256 & 0.297 & 0.306 & 0.233 & 0.205 & 0.160 & 0.215 & 0.131 \\
\hline 50 & 0.146 & 0.335 & 0.282 & 0.204 & 0.191 & 0.213 & 0.287 & 0.203 & 30.290 & 0.158 & 0.176 & 0.146 \\
\hline 51 & 0.324 & 0.299 & 0.177 & 0.270 & 0.303 & 0.297 & 0.394 & 0.220 & 0.158 & 0.182 & 0.161 & .135 \\
\hline 52 & 0.242 & 0.320 & 0.247 & 0.177 & 0.194 & 0.266 & 0.278 & 0.242 & 0.192 & 0.184 & 0.135 & .121 \\
\hline 53 & 0.218 & 0.206 & 0.311 & 0.288 & 0.336 & 0.262 & 0.200 & 0.191 & 0.214 & 0.155 & 0.137 & \\
\hline 54 & 0.275 & 0.168 & 0.136 & 0.211 & 0.184 & 0.274 & 0.213 & 0.165 & 0.222 & 0.119 & 0.092 & 0.069 \\
\hline 55 & 0.215 & 0.226 & 0.214 & 0.144 & 0.221 & 0.215 & 0.167 & 0.254 & 40.234 & 0.119 & 0.091 & 0.104 \\
\hline 56 & 0.204 & 0.208 & 0.193 & 0.253 & 0.255 & 0.235 & 0.248 & 0.176 & 0.180 & 0.092 & 0.098 & 0.101 \\
\hline 57 & 0.130 & 0.109 & 0.126 & 0.194 & 0.225 & 0.198 & 0.147 & 0.200 & 0.133 & 0.086 & 0.126 & 0.065 \\
\hline 58 & 0.172 & 0.111 & 0.206 & 0.090 & 0.200 & 0.130 & 0.187 & 0.113 & 0.099 & 0.139 & 0.155 & 0.071 \\
\hline 59 & 0.112 & 0.133 & 0.179 & 0.212 & 0.183 & 0.144 & 0.157 & 0.188 & 30.187 & 0.113 & 0.119 & 0.073 \\
\hline 60 & 0.106 & 0.107 & 0.075 & 0.091 & 0.082 & 0.136 & 0.145 & 0.172 & 0.138 & 0.169 & 0.056 & 0.053 \\
\hline 61 & 0.115 & 0.160 & 0.140 & 0.104 & 0.179 & 0.198 & 0.159 & 0.110 & 0.112 & 0.084 & 0.148 & 0.057 \\
\hline $6:$ & $\therefore 111$ & 0.103 & 0.111 & 0.098 & 0.120 & 0.149 & 0.143 & 0.134 & 40.152 & 0.113 & 0.074 & 54 \\
\hline 63 & 0.079 & 0.096 & 0.159 & 0.137 & 0.142 & 0.189 & 0.089 & 0.0 & 40.067 & 0.071 & 0.091 & 25 \\
\hline 64 & 0.132 & 0.090 & 0.053 & 0.085 & 0.150 & 0.104 & 0.088 & 0.105 & 5 0.152 & 0.094 & 0.084 & 0.148 \\
\hline 65 & 0.095 & 0.099 & 0.096 & 0.099 & 0.138 & 30.084 & 0.074 & 0.096 & 0.108 & 0.125 & 0.166 & 0.351 \\
\hline 66 & 0.055 & 0.121 & 0.087 & 0.078 & 0.073 & 0.160 & 0.175 & 0.172 & $? 0.083$ & 0.099 & 0.199 & 0.218 \\
\hline 67 & 0.103 & 0.109 & 0.067 & 0.093 & 0.095 & 0.117 & 0.103 & 0.099 & 9.142 & 0.210 & 0.259 & 0.288 \\
\hline 68 & 0.087 & 0.093 & 0.140 & 0.156 & 0.147 & 0.155 & 0.164 & 0.141 & 0.226 & 0.289 & 0.602 & 0.436 \\
\hline (.: & 0.135 & 0.133 & 0.111 & 0.122 & 0.151 & 0.155 & 0.123 & 0.218 & 30.314 & 0.388 & 0.369 & 0.395 \\
\hline 70 & 0.406 & 0.150 & 0.15 & 0.173 & 0.171 & 0.236 & 0.241 & 0.290 & 0.444 & 0.696 & 0.559 & 0.513 \\
\hline 71 & 0.3 & 0.195 & 0.1 & 0.2 & 0.233 & 46 & 0.343 & 0.409 & 0.499 & 04 & 0.597 & 0.624 \\
\hline 72 & 0.3 & 0.344 & 0.280 & 0.2 & 0.2 & 0.3 & 0.3 & 0.4 & 50.7 & 03 & 75 & 0.651 \\
\hline 73 & 0.372 & 0.524 & 0.437 & 0.3 & & 0.440 & $0.4 \subseteq$ & 0.752 & 20.7 & 0.906 & 0.801 & 0.781 \\
\hline 14 & 0.515 & 0.458 & 0.600 & 0.618 & 0.434 & 0.578 & 0.699 & 0.759 & 9 0.919 & 1.014 & 0.935 & 0.891 \\
\hline 75 & 0.652 & 0.618 & 0.563 & 0.644 & 0.8 & 0.838 & 0.8 & 0.9 & 51.0 & 1.056 & 1.048 & 0.950 \\
\hline 76 & 0.773 & 0.747 & 0.746 & 0.806 & 0.849 & 0.909 & 1.045 & 1.110 & 1.131 & 1.251 & 1.178 & 1.073 \\
\hline 77 & 0.924 & 0.884 & 0.988 & 0.948 & 0.996 & 1.095 & 1.258 & 1.266 & 1.323 & 1.374 & 1.282 & 1.166 \\
\hline 78 & 1.034 & 1.103 & 1.080 & 1.211 & 1.266 & 1.336 & 1.409 & 1.411 & 1.469 & 1.480 & 1.384 & 1.241 \\
\hline 79 & 1.256 & 1.208 & 1.293 & 1.320 & 1.430 & 1.533 & 1.554 & 1.559 & 1.567 & 1.591 & 1.431 & 1.408 \\
\hline 80 & 1.401 & 1.400 & 1.429 & 1.518 & 1.577 & 1.636 & 1.721 & 1.683 & 1.650 & 1.636 & 1.568 & 1.483 \\
\hline 81 & 1.504 & 1.578 & 1.526 & 1.647 & 1.741 & 1.835 & 1.859 & 1.790 & 1.746 & 1.721 & 1.710 & .nd \\
\hline 82 & 1.687 & 1.671 & 1.736 & 1.786 & 1.833 & 1.891 & 1.935 & 1.896 & 1.828 & 1.846 & 1.637 & .nd \\
\hline 83 & 1.773 & 1.795 & 1.879 & 1.897 & 1.952 & 1.998 & 2.033 & 1.965 & 1.899 & 1.852 & .nd & .nd \\
\hline 84 & 1.846 & 1.877 & 1.938 & 2.021 & 2.047 & 2.095 & 2.111 & 2.045 & 1.923 & .nd & .nd & .nd \\
\hline 85 & 1.775 & 1.976 & 2.028 & 2.077 & 2.138 & 2.138 & 2.137 & 2.031 & 12.061 & .nd & .nd & .nd \\
\hline 86 & .nd & 1.931 & 2.082 & 2.228 & 2.152 & 2.190 & 2.217 & 2.171 & 1 .nd & .nd & .nd & .nd \\
\hline 87 & .nd & .nd & .nd & 2.184 & 2.253 & 2.219 & 2.178 & 2.082 & .nd & .nd & .nd & .nd \\
\hline 88 & .nd & .nd & .nd & 2.119 & 2.218 & 2.204 & .na & .nd & .nd & .nd & .nd & .nd \\
\hline 89 & .nd & .nd & .nd & .nd & .nd & 2.356 & 2.182 & .nd & .nd & .nd & .nd & .nd \\
\hline
\end{tabular}




\begin{tabular}{|c|c|c|c|c|c|c|c|c|c|c|c|c|}
\hline \multirow{2}{*}{\multicolumn{2}{|c|}{ hour $\rightarrow 1$}} & \multicolumn{2}{|c|}{$\begin{array}{l}\text { C12: Centra } \\
\text { Standard }\end{array}$} & $\begin{array}{l}\text { al Air } \\
\text { Devia }\end{array}$ & \multicolumn{2}{|c|}{$\begin{array}{l}\text { Conditioner } \\
\text { tion of Loac }\end{array}$} & Raw & \multicolumn{3}{|c|}{$\begin{array}{l}\text { Time-Temperature } \\
\text { CEC Region } 4\end{array}$} & \multicolumn{2}{|c|}{ Matrix } \\
\hline & & 2 & 3 & 4 & 5 & 6 & 7 & 8 & 9 & 10 & 11 & 12 \\
\hline 45 & 0.325 & 0.322 & 0.329 & 0.340 & 0.352 & 0.362 & 0.356 & 0.411 & 0.353 & 0.353 & 0.296 & 0.310 \\
\hline 46 & 0.299 & 0.322 & 0.327 & 0.328 & 0.324 & 0.336 & 0.325 & 0.456 & 0.339 & 0.310 & 0.299 & 0.307 \\
\hline 47 & 0.311 & 0.302 & 0.297 & 0.317 & 0.309 & 0.307 & 0.308 & 0.342 & 0.333 & 0.322 & 0.301 & 0.272 \\
\hline 48 & 0.264 & 0.288 & 0.292 & 0.297 & 0.300 & 0.289 & 0.300 & 0.316 & 0.289 & 0.295 & 0.369 & 0.257 \\
\hline 49 & 0.275 & 0.282 & 0.278 & 0.271 & 0.279 & 0.272 & 0.269 & 0.335 & 0.285 & 0.271 & 0.269 & 0.242 \\
\hline 50 & 0.248 & 0.251 & 0.265 & 0.270 & 0.260 & 0.252 & 0.235 & 0.255 & 0.251 & 0.266 & 0.278 & 0.297 \\
\hline 51 & 0.240 & 0.243 & 0.237 & 0.227 & 0.223 & 0.231 & 0.226 & 0.262 & 0.232 & 0.269 & 0.251 & 0.269 \\
\hline 52 & 0.213 & 0.210 & 0.208 & 0.205 & 0.213 & 0.219 & 0.233 & 0.248 & 0.243 & 0.229 & 0.231 & 0.208 \\
\hline 53 & 0.189 & 0.195 & 0.189 & 0.193 & 0.199 & 0.200 & 0.206 & 0.229 & 0.212 & 0.222 & 0.232 & 0.191 \\
\hline 54 & 0.176 & 0.171 & 0.169 & 0.174 & 0.168 & 0.193 & 0.190 & 0.217 & 0.190 & 0.195 & 0.203 & 0.230 \\
\hline 55 & 0.156 & 0.161 & 0.162 & 0.172 & 0.172 & 0.158 & 0.158 & 0.228 & 0.172 & 0.184 & 0.176 & 0.182 \\
\hline 56 & 0.144 & 0.148 & 0.129 & 0.131 & 0.137 & 0.132 & 0.300 & 0.420 & 0.490 & 0.134 & 0.158 & 0.162 \\
\hline 57 & 0.116 & 0.127 & 0.124 & 0.121 & 0.314 & 0.328 & 0.238 & 0.154 & 0.214 & 0.279 & 0.310 & 0.135 \\
\hline 58 & 0.112 & 0.127 & 0.322 & 0.398 & 0.099 & 0.111 & 0.189 & 0.285 & 0.104 & 0.291 & 0.103 & 0.112 \\
\hline 59 & 0.289 & 0.355 & 0.226 & 0.190 & 0.337 & 0.325 & 0.332 & 0.268 & 0.342 & 0.365 & 0.243 & 0.237 \\
\hline $6 ?$ & 0.437 & 0.247 & 0.238 & 0.355 & 0.139 & 0.203 & 0.232 & 0.278 & 0.261 & 0.347 & 0.383 & 0.266 \\
\hline$\epsilon$ & 0.393 & 0.298 & 0.297 & 0.122 & 0.387 & 0.377 & 0.344 & 0.336 & 0.334 & 0.389 & 0.346 & 0.320 \\
\hline$t$ & 0.198 & 0.233 & 0.250 & 0.445 & 0.143 & 0.151 & 0.197 & 0.199 & 0.221 & 0.196 & 0.415 & 0.367 \\
\hline $6:$ & 0.227 & 0.412 & 0.387 & 0.210 & 0.207 & 0.201 & 0.258 & 0.271 & 0.224 & 0.162 & 0.255 & 0.133 \\
\hline 64 & 0.322 & 0.273 & 0.261 & 0.251 & 0.335 & 0.303 & 0.152 & 0.185 & 0.299 & 0.309 & 0.155 & 0.189 \\
\hline 65 & 0.398 & 0.304 & 0.331 & 0.315 & 0.189 & 0.176 & 0.229 & 0.267 & 0.303 & 0.301 & 0.248 & 0.241 \\
\hline $6 t$ & 0.387 & 0.465 & 0.298 & 0.189 & 0.333 & 0.345 & 0.288 & 0.349 & 0.218 & 0.359 & 0.315 & 0.221 \\
\hline 67 & 0.580 & 0.419 & 0.382 & 0.495 & 0.473 & 0.428 & 0.706 & 0.403 & 0.372 & 0.424 & 0.330 & 0.325 \\
\hline 68 & 0.596 & 0.471 & 0.598 & 0.075 & .nd & 0.644 & .nd & 0.682 & 0.555 & 0.548 & 0.517 & 0.394 \\
\hline iU & $\therefore 856$ & 1.091 & 1.062 & 1.006 & 0.715 & .nd & .nd & 0.767 & 0.579 & 0.662 & 0.597 & 0.477 \\
\hline 70 & 0.616 & .nd & .nd & .nd & .nd & .nd & .nd & 0.788 & 0.821 & 0.595 & 0.737 & 0.621 \\
\hline 71 & 1.272 & .nd & .nd & .nd & .nd & .nd & .nd & .nd & 1.009 & 0.716 & 0.730 & 0.783 \\
\hline 72 & 1.506 & .nd & .nd & .nd & .nd & .nd & .nd & .nd & .nd & 1.066 & 0.754 & 0.954 \\
\hline $7 ?$ & .nd & .nd & .nd & .nd & .nd & .nd & .nd & .nd & .nd & 1.264 & 1.108 & 0.881 \\
\hline 74 & .nd & .nd & .nd & .nd & .nd & .nd & .nd & .nd & 1.077 & 1.021 & 1.113 & 1.079 \\
\hline 75 & .nd & .nd & .nd & .nd & .nd & .nd & .nd & .nd & .nd & 1.407 & 1.481 & 0.969 \\
\hline 76 & .nd & .nd & .nd & .nd & .nd & .nd & .nd & .nd & .nd & .nd & .nd & 1.197 \\
\hline 77 & .nd & .nd & .nd & .nd & .nd & .nd & .nd & .nd & .nd & .nd & 1.107 & 1.585 \\
\hline 78 & .nd & .nd & .nd & .nd & .nd & .nd & .nd & .nd & .nd & .nd & 1.685 & 1.756 \\
\hline 79 & .nd & .nd & .nd & .nd & .nd & .nd & .nd & .nd & .nd & .nd & .nd & no \\
\hline 80 & .nd & .nd & .nd & .nd & .nd & .nd & .nd & .nd & .nd & .nd & .nd & .nd \\
\hline 81 & nd & .nd & .nd & .nd & .nd & .nd & .nd & .nd & .nd & .nd & .nd & .nd \\
\hline 82 & .nd & .nd & .nd & .nd & .nd & .nd & .nd & .nd & .nd & .nd & .nd & .nd \\
\hline 83 & .nd & .nd & .nd & .nd & .nd & .nd & .nd & .nd & .nd & .nd & .nd & .nd \\
\hline 85 & .nd & .nd & .nd & .nd & .nd & .nd & .nd & .nd & .nd & .nd & .nd & .nd \\
\hline 86 & .nd & .nd & .nd & .nd & .nd & nd & .nd & .nd & .nd & .nd & .nd & .nd \\
\hline 87 & .nd & .nd & .nd & .nd & .nd & .nd & .nd & .nd & .nd & .nd & .nd & .nd \\
\hline 88 & nd & .nd & .nd & .nd & .nd & nd & .nd & .nd & .nd & .nd & .nd & .nd \\
\hline 89 & .nd & .nd & .nd & .nd & .nd & .nd & .nd & .nd & .nd & .nd & .nd & .nd \\
\hline
\end{tabular}

.nd = no data available 


\begin{tabular}{|c|c|c|c|c|c|c|c|c|c|c|c|c|}
\hline \multirow{2}{*}{\multicolumn{2}{|c|}{$\begin{array}{c}\text { Table } C \\
\text { hour } \rightarrow 13\end{array}$}} & \multirow{2}{*}{$\begin{array}{r}12 c \\
14\end{array}$} & $\begin{array}{l}\text { ont'd: } \\
\text { Standar }\end{array}$ & \multirow{2}{*}{$\begin{array}{c}\text { Central } \\
\text { d Devis } \\
16\end{array}$} & \multirow{2}{*}{$\begin{array}{l}\text { Air } \\
\text { ation } \\
17\end{array}$} & \multirow{2}{*}{$\begin{array}{c}\text { Conditiol } \\
\text { of Load } \\
18 \\
\end{array}$} & \multirow{2}{*}{$\begin{array}{c}\text { ner } \\
19\end{array}$} & \multirow{2}{*}{$\begin{array}{c}\text { Raw } \\
\text { CEC } \\
20\end{array}$} & \multirow{2}{*}{$\begin{array}{c}\text { Time-Ten } \\
\text { Region } \\
21\end{array}$} & \multicolumn{2}{|c|}{$\begin{array}{l}\text { nperature } \\
4\end{array}$} & Matrix \\
\hline & & & 15 & & & & & & & 22 & 23 & 24 \\
\hline 45 & .nd & 0.207 & .nd & .nd & .nd & .nd & .nd & .nd & 0.303 & 0.320 & 0.292 & 0.350 \\
\hline 46 & .nd & 0.293 & .nd & .nd & .nd & .nd & 0.298 & 8.277 & 0.224 & 0.343 & 0.348 & 0.327 \\
\hline 47 & 0.231 & 0.151 & 0.214 & 0.209 & 0.176 & 60.275 & 0.251 & 0.243 & 0.278 & 0.342 & 0.294 & 0.300 \\
\hline 48 & 0.258 & .nd & .nd & 0.199 & 0.213 & 0.225 & 0.214 & 40.282 & 0.301 & 0.255 & 0.288 & 0.300 \\
\hline 49 & 0.241 & 0.264 & 0.239 & 0.205 & 0.240 & 0.272 & 0.257 & 70.284 & 0.307 & 0.252 & 0.268 & 0.266 \\
\hline 50 & 0.235 & 0.223 & 0.260 & 0.186 & 0.219 & 0.235 & 0.274 & 40.300 & 0.232 & 0.259 & 0.263 & 0.248 \\
\hline 51 & 0.2 & 0.229 & 0.169 & 0.220 & 0.219 & 0.256 & 0.221 & 0.234 & 0.235 & 0.240 & 0.240 & 0.238 \\
\hline 52 & 0.253 & 0.182 & 0.201 & 0.190 & 0.266 & 0.235 & 0.206 & 0.208 & 0.224 & 0.227 & 0.225 & 0.210 \\
\hline 53 & 0.227 & 0.240 & 0.181 & 0.196 & 0.173 & 30.241 & 0.200 & 0.206 & 0.215 & 0.199 & 0.211 & 0.210 \\
\hline 54 & 0.181 & 0.166 & 0.152 & 0.173 & 0.209 & 0.213 & 0.191 & 0.203 & 0.215 & 0.199 & 0.179 & 0.185 \\
\hline 55 & 0.185 & 0.171 & 0.167 & 0.180 & 0.191 & 0.177 & 0.186 & 0.169 & 0.172 & 0.164 & 0.154 & 0.154 \\
\hline 56 & 0.167 & 0.185 & 0.158 & 0.158 & 0.155 & 0.173 & 0.155 & 50.143 & 0.150 & 0.150 & 0.151 & 0.140 \\
\hline 57 & 0.131 & 0.149 & 0.155 & 0.143 & 0.149 & 0.154 & 0.135 & 0.138 & 0.135 & 0.137 & 0.121 & 0.129 \\
\hline 58 & 0.128 & 0.130 & 0.133 & 0.120 & 0.158 & 0.134 & 0.123 & 0.114 & 0.112 & 0.112 & 0.104 & 0.115 \\
\hline 59 & 0.103 & 0.082 & 0.115 & 0.145 & 0.132 & 0.131 & 0.124 & 40.102 & 0.100 & 0.112 & 0.229 & 0.317 \\
\hline 60 & 0.096 & 0.091 & 0.087 & 0.093 & 0.103 & 0.120 & 0.122 & 0.104 & 0.124 & 0.155 & 0.110 & 0.116 \\
\hline 61 & 0.158 & 0.092 & 0.095 & 0.089 & 0.087 & 0.110 & 0.116 & 0.105 & 0.172 & 0.410 & 0.420 & 0.370 \\
\hline 62 & 0.118 & 0.2 & 0.0 & 0.079 & 0.074 & 0.109 & 0.132 & 0.124 & 0.369 & 0.374 & 0.381 & 0.414 \\
\hline 63 & 0.1 & 0.097 & 0.2 & 0.112 & 0.111 & 0.121 & 0.142 & 0.373 & 0.437 & 0.349 & 0.284 & 0.245 \\
\hline 64 & 0.147 & 0.093 & 0.1 & 0.099 & 0.153 & 0.153 & 0.361 & 0.462 & 0.385 & 0.418 & 0.423 & 0.352 \\
\hline 65 & 0.231 & 0.153 & 0.109 & & 0.252 & 0.307 & 0.272 & 0.433 & 0.431 & 0.483 & 0.458 & 0.442 \\
\hline 66 & 0.10 & 0.141 & 0.253 & 0.210 & & 0.305 & 0.526 & 0.472 & 0.412 & 0.615 & 0.568 & 0.534 \\
\hline 67 & 0.241 & 0.178 & 0.211 & 0.237 & 0.416 & 0.414 & 0.526 & 0.542 & 0.670 & 0.752 & 0.768 & 0.574 \\
\hline 68 & 0.336 & 0.341 & 0.367 & 0.433 & 0.525 & 0.538 & 0.652 & 0.701 & 0.793 & 0.809 & 0.782 & 0.774 \\
\hline 69 & 0.393 & 0.315 & 0.3 & 0.2 & 0.529 & 0.657 & 0.792 & 0.883 & 0.953 & 1.083 & 0.942 & 0.831 \\
\hline 70 & 0.553 & 0.476 & 0.4 & & 0.643 & 0.814 & 0.833 & 0.998 & 1.120 & 1.005 & 1.281 & 1.016 \\
\hline 71 & 0.652 & 0.570 & 0.5 & 0.673 & 0.812 & 1.012 & 1.179 & 1.135 & 1.269 & 1.278 & 1.173 & 1.144 \\
\hline 72 & 0.717 & 0.704 & 0.7 & & 1.046 & 1.210 & 1.250 & 1.384 & 1.363 & 1.531 & 1.038 & .nd \\
\hline 73 & 0.942 & 0.906 & 0.8 & 1.0 & 1.180 & 1.242 & 1.373 & 1.538 & 1.487 & 1.426 & .nd & 1.615 \\
\hline 74 & 1.150 & 0.954 & 1.013 & 1.1 & 1.326 & 1.483 & 1.577 & 1.610 & 1.487 & .nd & 1.799 & .nd \\
\hline 75 & 1.196 & 1.208 & 1.180 & 1.325 & 1.438 & 1.592 & 1.721 & 1.666 & 1.729 & .nd & .nd & .no \\
\hline 76 & 0.994 & 1.416 & 1.333 & 1.447 & 1.683 & 1.764 & 1.825 & 1.720 & $\begin{array}{ll}0 & 1.583\end{array}$ & 1.880 & .nd & .nd \\
\hline 77 & 1.436 & 1.491 & 1.648 & 1.599 & 1.648 & 1.757 & 1.861 & 1.855 & 5 .nd & .nd & .nd & .nd \\
\hline 78 & 1.450 & 1.496 & 1.583 & 1.665 & 1.793 & 1.855 & 1.993 & 1.942 & 21.980 & .nd & .nd & .nd \\
\hline 79 & 1.799 & 1.577 & 1.761 & 1.843 & 1.820 & 1.965 & 2.050 & 1.777 & 7 .nd & .nd & .nd & .nd \\
\hline 80 & .nd & 1.778 & 1.688 & 1.915 & 2.073 & 2.068 & 1.916 & .nd & .nd & .nd & .nd & .nd \\
\hline 81 & 1.992 & .nd & 1.891 & 2.075 & 1.986 & 2.026 & 1.916 & 2.117 & .nd & .nd & .nd & .nd \\
\hline 82 & .nd & . na & .nd & 1.820 & 1.955 & 2.040 & .nd & .nd & .nd & .nd & .nd & .nd \\
\hline 83 &.$n c$ & 2.182 & .nd & 1.934 & .nd & .nd & 2.185 & .nd & .nd & .nd & .nd & .nd \\
\hline 85 &.$n$ & .nd & 2.287 & .nd & .nd & 2.226 & .nd & .nd & .nd & .nd & .nd & .nd \\
\hline $8 \epsilon$ &. nc & .170 & .nd & 2.365 & 2.370 & .nd & .nd & .nd & .nd & .nd & .nd & .nd \\
\hline 87 &.$n c$ & . no & .nd & 2.365 & 2.370 & .nd & .nd & .nd & .nd & .nd & .nd & .nd \\
\hline 88 &.$n$ & .na & .nd & 2.365 & 2.370 & .nd & .nd & .nd & .nd & .nd & .nd & .nd \\
\hline 89 & .nd & .nd & .nd & 2.365 & 2.370 & .nd & .nd & .nd & .nd & .nd & .nd & .nd \\
\hline
\end{tabular}

.nd = no data available 


\begin{tabular}{|c|c|c|c|c|c|c|c|c|c|c|c|c|}
\hline \multicolumn{3}{|c|}{ Table C13: } & \multirow{2}{*}{$\begin{array}{l}\text { Central } \\
\text { Mean } \\
3\end{array}$} & \multirow{2}{*}{$\begin{array}{c}\text { Air C } \\
4\end{array}$} & \multirow{2}{*}{\multicolumn{2}{|c|}{$\begin{array}{l}\text { Conditioner } \\
\text { d in kWh fo } \\
\qquad \begin{array}{r}5 \\
6\end{array}\end{array}$}} & \multirow{2}{*}{\multicolumn{2}{|c|}{$\begin{array}{rr}\text { Smoothed } & T \\
\text { or all } & \text { CEC } \\
7 & 8\end{array}$}} & \multicolumn{2}{|c|}{$\begin{array}{l}\text { ime-Temperature } \\
\text { Reglons }\end{array}$} & \multicolumn{2}{|c|}{ Matrix } \\
\hline & & 2 & & & & & & & 9 & 10 & 11 & 12 \\
\hline 45 & 0.000 & 0.000 & 0.000 & 0.000 & 0.000 & 0.000 & 0.000 & 0.000 & 0.000 & 0.000 & 0.000 & 0.000 \\
\hline 46 & 0.000 & 0.000 & 0.000 & 0.000 & 0.000 & 0.000 & 0.000 & 0.000 & 0.000 & 0.000 & 0.000 & 0.000 \\
\hline 47 & 0.000 & 0.000 & 0.000 & 0.000 & 0.000 & 0.000 & 0.000 & 0.000 & 0.000 & 0.000 & 0.000 & 0.000 \\
\hline 48 & 0.000 & 0.000 & 0.000 & 0.000 & 0.000 & 0.000 & 0.000 & 0.000 & 0.000 & 0.000 & 0.000 & 0.000 \\
\hline 49 & 0.000 & 0.000 & 0.000 & 0.000 & 0.000 & 0.000 & 0.000 & 0.000 & 0.000 & 0.000 & 0.000 & 0.000 \\
\hline 50 & 0.000 & 0.000 & 0.000 & 0.000 & 0.000 & 0.000 & 0.000 & 0.000 & 0.000 & 0.000 & 0.000 & 0.000 \\
\hline 51 & 0.000 & 0.000 & 0.000 & 0.000 & 0.000 & 0.000 & 0.000 & 0.000 & 0.000 & 0.000 & 0.000 & 0.000 \\
\hline 52 & 0.000 & 0.000 & 0.000 & 0.000 & 0.000 & 0.000 & 0.000 & 0.000 & 0.000 & 0.000 & 0.000 & 0.000 \\
\hline 53 & 0.000 & 0.000 & 0.000 & 0.000 & 0.000 & 0.000 & 0.000 & 0.000 & 0.000 & 0.000 & 0.000 & 0.000 \\
\hline 54 & 0.000 & 0.000 & 0.000 & 0.000 & 0.000 & 0.000 & 0.000 & 0.000 & 0.000 & 0.000 & 0.000 & 0.000 \\
\hline 55 & 0.000 & 0.000 & 0.000 & 0.000 & 0.000 & 0.000 & 0.000 & 0.000 & 0.001 & 0.001 & 0.000 & 0.000 \\
\hline 56 & 0.001 & 0.000 & 0.000 & 0.000 & 0.000 & 0.000 & 0.001 & 0.001 & 0.001 & 0.001 & 0.001 & 0.001 \\
\hline 57 & 0.001 & 0.001 & 0.001 & 0.001 & 0.001 & 0.001 & 0.001 & 0.001 & 0.001 & 0.001 & 0.001 & 0.001 \\
\hline 58 & 0.002 & 0.001 & 0.001 & 0.001 & 0.001 & 0.001 & 0.002 & 0.002 & 0.002 & 0.002 & 0.002 & 0.001 \\
\hline 59 & 0.003 & 0.002 & 0.002 & 0.002 & 0.002 & 0.002 & 0.003 & 0.003 & 0.003 & 0.003 & 0.003 & 0.002 \\
\hline 60 & 0.005 & 0.003 & 0.003 & 0.002 & 0.003 & 0.003 & 0.004 & 0.005 & 0.005 & 0.005 & 0.004 & 0.003 \\
\hline 61 & 0.007 & 0.005 & 0.004 & 0.004 & 0.004 & 0.005 & 0.006 & 0.007 & 0.007 & 0.007 & 0.006 & 0.005 \\
\hline 62 & 0.011 & 0.008 & 0.006 & 0.006 & 0.006 & 0.007 & 0.008 & 0.010 & 0.011 & 0.010 & 0.009 & 0.008 \\
\hline 63 & 0.015 & 0.011 & 0.009 & 0.008 & 0.009 & 0.010 & 0.012 & 0.014 & 0.015 & 0.015 & 0.013 & 0.011 \\
\hline 64 & 0.022 & 0.016 & 0.013 & 0.012 & 0.013 & 0.014 & 0.017 & 0.020 & 0.021 & 0.020 & 0.018 & 0.015 \\
\hline 65 & 0.031 & 0.024 & 0.019 & 0.018 & 0.018 & 0.020 & 0.024 & 0.027 & 0.029 & 0.028 & 0.025 & 0.021 \\
\hline 66 & 0.043 & 0.033 & 0.028 & 0.025 & 0.026 & 0.029 & 0.033 & 0.037 & 0.039 & 0.038 & 0.034 & 0.029 \\
\hline 67 & 0.059 & 0.046 & 0.039 & 0.036 & 0.036 & 0.039 & 0.044 & 0.049 & 0.052 & 0.050 & 0.046 & 0.040 \\
\hline 68 & 0.080 & 0.064 & 0.054 & 0.050 & 0.050 & 0.054 & 0.060 & 0.066 & 0.068 & 0.067 & 0.061 & 0.054 \\
\hline 69 & 0.107 & 0.086 & 0.074 & 0.068 & 0.068 & 0.072 & 0.080 & 0.086 & 0.090 & 0.087 & 0.080 & 0.071 \\
\hline 70 & 0.141 & 0.116 & 0.100 & 0.092 & 0.091 & 0.096 & 05 & & 0.116 & 0.113 & 0.104 & 0.094 \\
\hline 71 & 0.185 & 0.154 & 0.133 & 0.123 & 0.122 & 0.127 & 0.137 & 0.146 & 0.149 & 0.145 & 0.134 & 0.122 \\
\hline 72 & 0.240 & 0.202 & 0.176 & 0.163 & 0.160 & 0.166 & 0.176 & 0.186 & 0.190 & 0.185 & 0.172 & 0.157 \\
\hline 73 & 0.308 & 0.263 & 0.231 & 0.214 & 0.209 & 0.215 & 0.226 & 0.236 & 0.239 & 0.233 & 0.218 & 0.201 \\
\hline 74 & 0.391 & 0.338 & 0.300 & 0.278 & 0.270 & 0.275 & 0.286 & 0.297 & 0.300 & 0.291 & 0.274 & 0.254 \\
\hline 75 & 0.493 & 0.431 & 0.385 & 0.357 & 0.346 & 0.349 & 0.359 & 0.370 & 0.372 & 0.361 & 0.342 & 0.320 \\
\hline 76 & 0.614 & 0.544 & 0.489 & 0.455 & 0.439 & 0.439 & 0.448 & 0.457 & 0.457 & 0.445 & 0.422 & 0.398 \\
\hline 77 & 0.758 & 0.679 & 0.616 & 0.573 & 0.551 & 0.547 & 0.553 & 0.559 & 0.558 & 0.543 & 0.518 & 0.491 \\
\hline 78 & 0.926 & 0.840 & 0.767 & 0.715 & 0.685 & 0.675 & 0.677 & 0.680 & 0.675 & 0.658 & 0.630 & 0.602 \\
\hline 79 & 1.119 & 1.027 & 0.945 & 0.883 & 0.844 & 0.825 & 0.821 & 0.819 & 0.810 & 0.790 & 0.760 & 0.731 \\
\hline 80 & 1.338 & 1.241 & 1.151 & 1.078 & 1.028 & 0.999 & 0.986 & 0.978 & 0.964 & 0.940 & 0.909 & 0.879 \\
\hline 81 & 1.581 & 1.482 & 1.385 & 1.301 & 1.238 & 1.198 & 1.174 & 1.157 & 1.137 & 1.110 & 1.077 & 1.049 \\
\hline 82 & 1.845 & 1.748 & 1.645 & 1.551 & 1.474 & 1.420 & 1.383 & 1.356 & 1.330 & 1.299 & 1.266 & 1.239 \\
\hline 83 & 2.125 & 2.034 & 1.929 & 1.825 & 1.735 & 1.664 & 1.613 & 1.575 & 1.541 & 1.506 & 1.473 & 1.450 \\
\hline 84 & 2.416 & 2.333 & 2.229 & 2.118 & 2.014 & 1.928 & 1.861 & 1.810 & 1.768 & 1.730 & 1.699 & 1.680 \\
\hline 85 & 2.708 & 2.637 & 2.538 & 2.423 & 2.308 & 2.206 & 2.123 & 2.059 & 2.008 & 1.968 & 1.939 & 1.927 \\
\hline 86 & 2.993 & 2.936 & 2.845 & 2.730 & 2.607 & 2.491 & 2.394 & 2.317 & 2.259 & 2.216 & 2.190 & 2.185 \\
\hline 87 & 3.259 & 3.218 & 3.139 & 3.028 & 2.902 & 2.777 & 2.666 & 2.578 & 2.513 & 2.469 & 2.448 & 2.451 \\
\hline 88 & 3.499 & 3.472 & 3.407 & 3.306 & 3.182 & 3.052 & 2.933 & 2.837 & 2.766 & 2.722 & 2.705 & 2.716 \\
\hline 89 & 3.704 & 3.690 & 3.639 & 3.552 & 3.436 & 3.308 & 3.187 & 3.085 & 3.012 & 2.969 & 2.957 & 2.975 \\
\hline
\end{tabular}




\begin{tabular}{|c|c|c|c|c|c|c|c|c|c|c|c|c|}
\hline & & & t'd: & Load & $\begin{array}{l}\text { Air } \\
\text { in }\end{array}$ & is & a & $C$ & gio & & & \\
\hline \multicolumn{2}{|c|}{ hour $\rightarrow 13$} & 14 & 15 & 16 & 17 & 18 & 19 & 20 & 21 & 22 & 23 & 24 \\
\hline 45 & 0.000 & 0.000 & 0.000 & 0.000 & 0.000 & 0.000 & 0.000 & & & 0.000 & .000 & 0.000 \\
\hline 46 & & & & & & & & & & & & \\
\hline 47 & 000 & 0.00 & 0.000 & 0.0 & 0.000 & 0.000 & 0.000 & 0.0 & 0.000 & 0.000 & & \\
\hline 48 & 0.000 & 0.000 & 0.000 & 0.000 & 0.000 & 0.000 & 0.000 & 0.0 & 0.000 & 0.000 & 0.000 & \\
\hline 49 & 0.000 & 0.000 & 0.000 & 0.000 & 0.000 & 0.000 & 0.000 & 0.000 & 0.000 & 0.000 & 0.000 & 0.000 \\
\hline 50 & 0.000 & 0.000 & 0.000 & 0.000 & 0.000 & 0.000 & 0.000 & 0.000 & 0.000 & 0.000 & 0.000 & 0.000 \\
\hline 51 & 0.000 & 0.000 & 0.000 & 0.0 & 0.000 & 0.000 & 0.000 & 0.0 & 0.000 & 0.000 & & 0.000 \\
\hline 52 & 0.000 & 0.06 & 0.000 & 0.0 & 0.000 & 0.000 & & & 0.0 & & & \\
\hline 53 & 0.0 & 0.0 & 0.0 & & 0.0 & 0.0 & & & & & & \\
\hline 54 & & 0.0 & 0.0 & 0.0 & 0. & 0.0 & & & & & & \\
\hline 55 & & 0.0 & 0.0 & 0.0 & 0.000 & 0.0 & & & & & & \\
\hline 56 & & & & & & 0 & & & & & & \\
\hline 57 & 0.001 & 0.001 & 0.001 & 0.001 & 0.001 & & & & & & & \\
\hline 58 & 0.001 & 0.001 & 0.001 & 0.001 & 0.002 & 0.003 & 0.004 & 0.006 & 0.007 & 0.006 & 0.005 & 0.003 \\
\hline 59 & 0.002 & 0.002 & 0.002 & 0.002 & 0.003 & 0.005 & 0.007 & 0.009 & 0.010 & 0.009 & 0.007 & 0.005 \\
\hline 60 & & 0.003 & & & & 0.007 & 0.0 & & $0 . c$ & 13 & 0.010 & 007 \\
\hline 61 & & 0.0 & & & & & & & 0.0 & & & \\
\hline 62 & & & & & & & & & & & & \\
\hline 63 & & & & & & & & & & & & \\
\hline 64 & & 0.0 & & & & 0.0 & & & & & & \\
\hline 65 & 0.019 & 0.017 & 0.018 & & & 0.0 & & & 38 & & & \\
\hline 66 & 0.026 & 0.024 & 0.026 & 0.030 & 0.038 & 0.0 & 0.0 & & 0.0 & & & \\
\hline 67 & 0.036 & 0.034 & 0.035 & 0.041 & 0.052 & 0.068 & 0.089 & & & & & \\
\hline 68 & 0.048 & 0.04 & 0.048 & 0.056 & 0.070 & 0.091 & 0.115 & 0.138 & 0.149 & 0.1 & 0.125 & \\
\hline 69 & & 0.06 & 0.065 & 0.075 & 0.093 & 0.118 & 0.149 & 0.176 & 0.190 & 0.184 & 0.162 & 0.133 \\
\hline 70 & & 0.08 & 0.087 & & 0.121 & 0.153 & $0.1 \mathrm{~s}$ & 0.223 & 0.239 & 0.233 & 0.208 & 0.174 \\
\hline 71 & & 0.109 & 0.114 & 0.130 & 0.158 & 0.197 & 0.241 & 0.279 & 0.299 & 0.293 & 0.264 & 0.224 \\
\hline 72 & & 0.1 & 0.1 & 0.1 & 0.203 & 0.250 & 0.302 & 0.347 & 0.370 & 0.364 & 0.332 & 0.286 \\
\hline 73 & & & & & 0.259 & 0.314 & 0.375 & 0.428 & 0.455 & 0.449 & 0.414 & 0.362 \\
\hline 74 & & 0.2 & 0.2 & & 0.328 & 0.392 & 0.463 & 0.522 & 0.554 & 0.549 & 0.511 & 0.453 \\
\hline 75 & & & & & & 0.485 & 0.5 & 0.6 & 0.669 & 0.665 & 0.625 & 0.562 \\
\hline 76 & & & & & 0.5 & 0.5 & & & 0.8 & 0.799 & 0.758 & 0.691 \\
\hline 77 & & & & & & & & & & 0.8 & 11 & 0.841 \\
\hline 78 & 0.584 & 0.587 & 0.616 & & & & & & & & & 1.013 \\
\hline 79 & 0.714 & 0.719 & 0.755 & 0.824 & & & & & & & & \\
\hline 80 & 0.864 & 0.874 & 0.917 & 0.995 & 1.103 & 1.227 & 1.3 & 1.4 & 1.5 & 22 & & \\
\hline 81 & 1.037 & 1.052 & 1.103 & 1.190 & 1.305 & 1.436 & 1.561 & 1.662 & & & 24 & \\
\hline 82 & 1.232 & 1.254 & 1.313 & 1.408 & 1.530 & 1.663 & 1.789 & 1.890 & 1.956 & & 1.970 & 1.922 \\
\hline 83 & 1.449 & 1.479 & 1.546 & 1.647 & 1.774 & 1.907 & 2.030 & 2.129 & 2.196 & 2.2 & 2.227 & 2.192 \\
\hline 84 & 1.686 & 1.724 & 1.799 & 1.906 & 2.033 & 2.163 & 2.281 & 2.375 & 2.441 & 2.4 & 2.490 & 2.469 \\
\hline 85 & 1.941 & 1.988 & 2.069 & 2.179 & 2.303 & 2.426 & 2.534 & 2.621 & 2.686 & & & 2.745 \\
\hline 86 & 2.208 & 2.264 & 2.350 & 2.459 & 2.577 & 2.689 & 2.786 & 2.864 & 2.925 & 2.973 & 3.004 & 3.01 .3 \\
\hline 87 & 2.483 & 2.545 & 2.635 & 2.741 & 2.848 & 2.947 & 3.029 & & 3.153 & 3.202 & 3.242 & 3.265 \\
\hline 88 & .757 & 2.825 & 2.915 & & & & & & & & 3.459 & 3.491 \\
\hline 00 & & & & 3.269 & 3.349 & 3.414 & 3.465 & 3.509 & 3.553 & 3.601 & 3.649 & 3.687 \\
\hline
\end{tabular}




\section{Appendix D \\ Data Tables for Chapter 6}




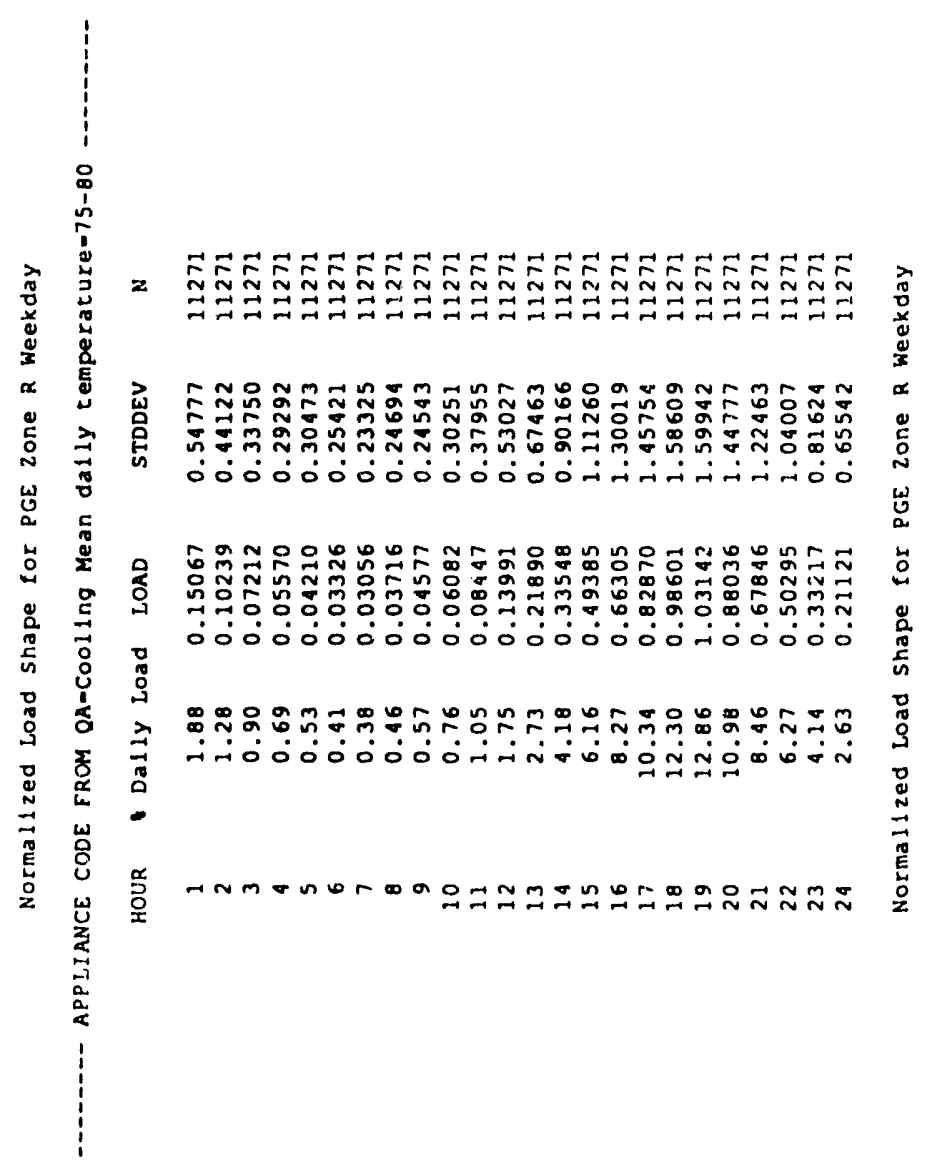

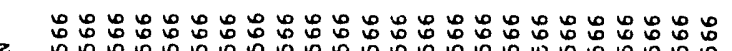

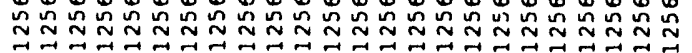

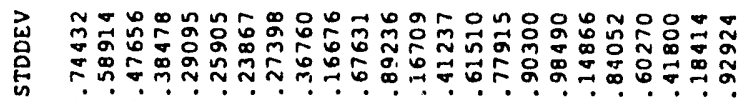

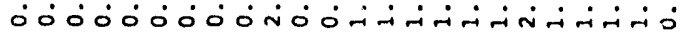

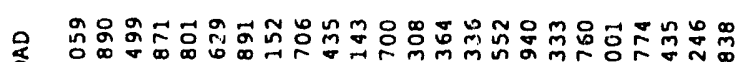

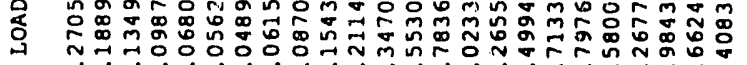

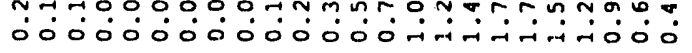
$\stackrel{8}{9}$

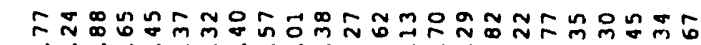

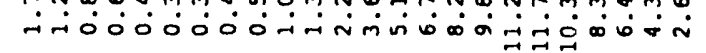

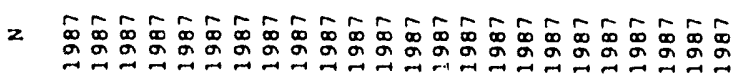

己

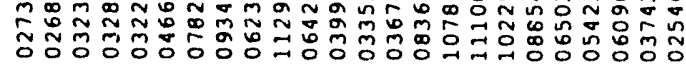

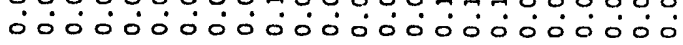

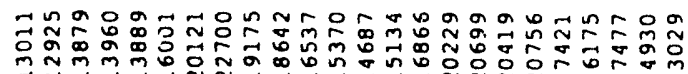

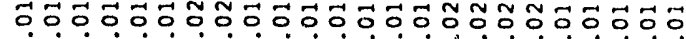

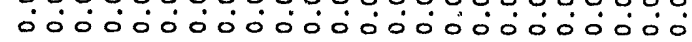

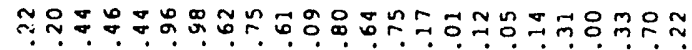

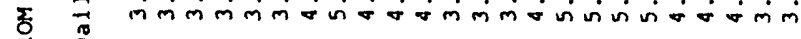

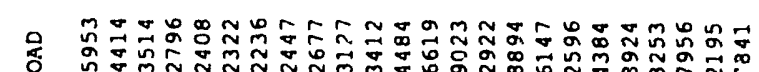

实

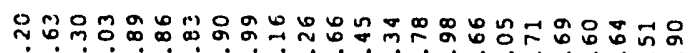

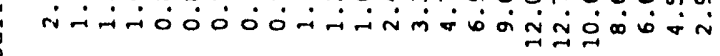


z

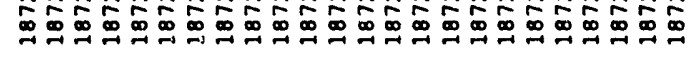

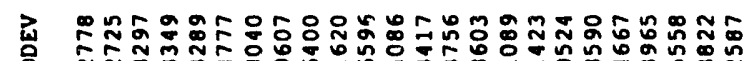

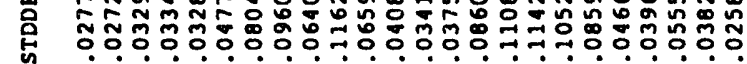

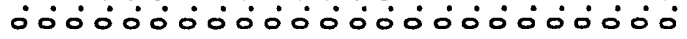

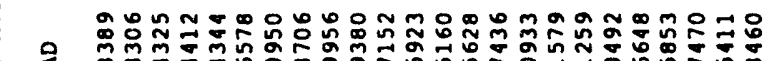
mm

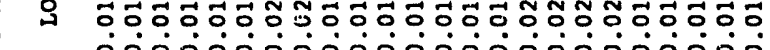
\$. 000000000000000000000000

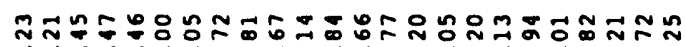

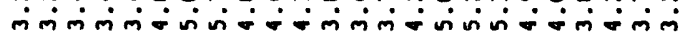

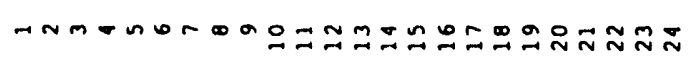

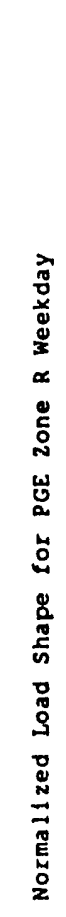

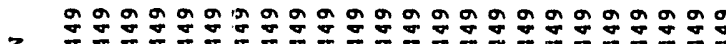

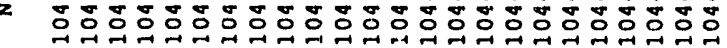

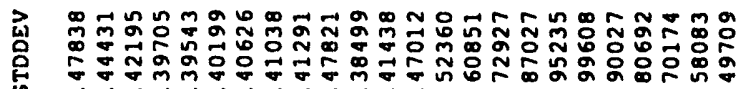

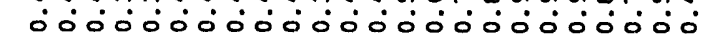

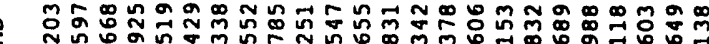

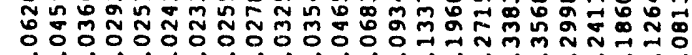
ó00000000000000000. :

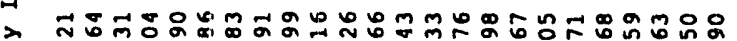

त

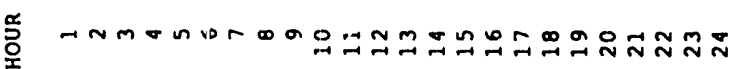
晒

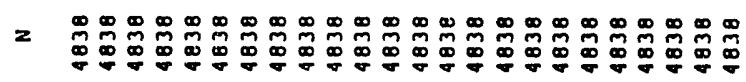

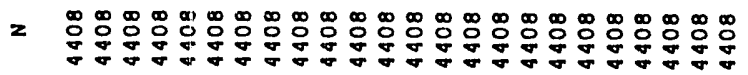

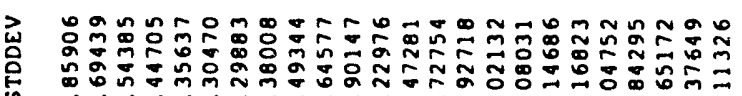

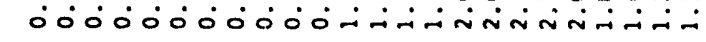

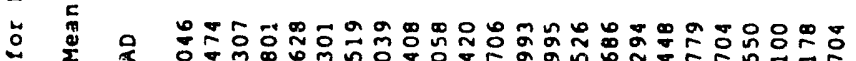
व

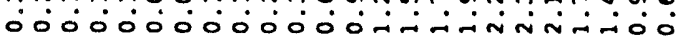

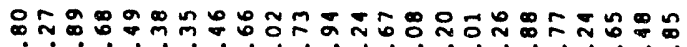

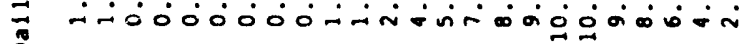

\section{г} 莕 옹

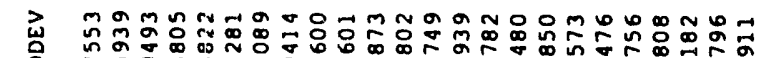

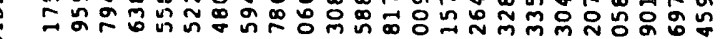

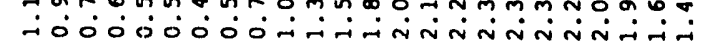

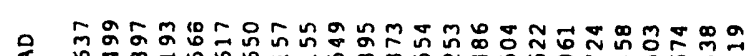

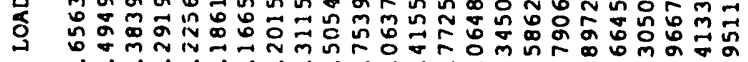

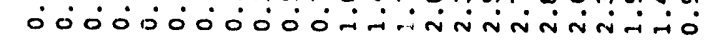
(2)

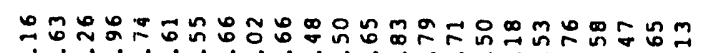

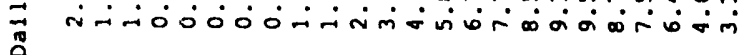




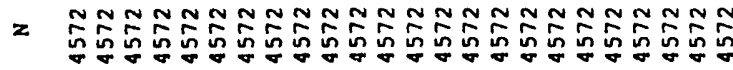

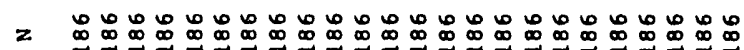

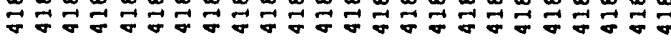

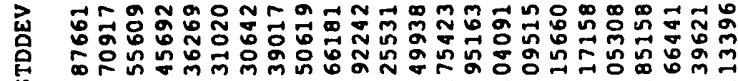

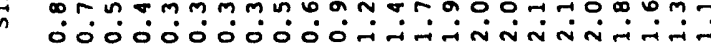

西

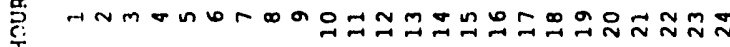

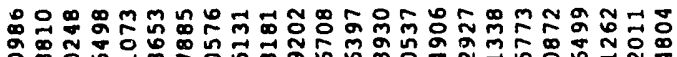

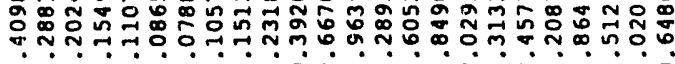

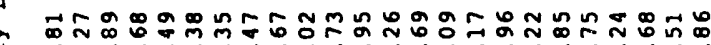

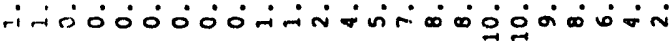
出

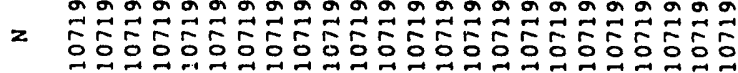

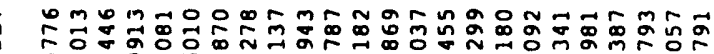

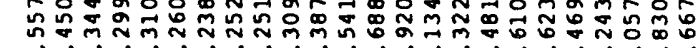

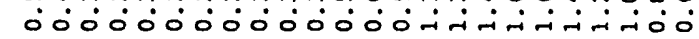

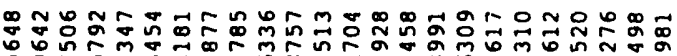

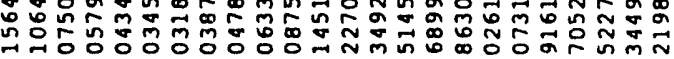
000000000000000 :

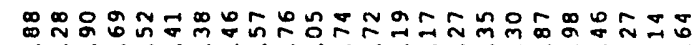
-

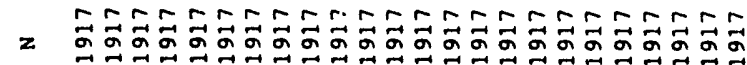

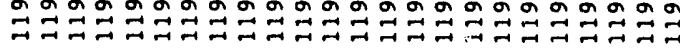

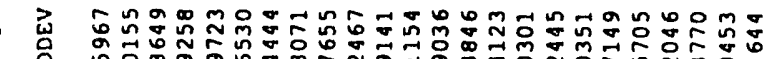

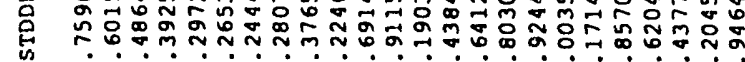
w

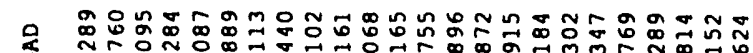

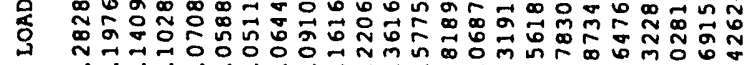
:

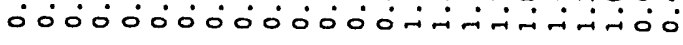

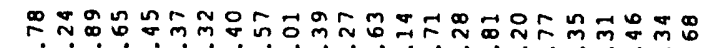

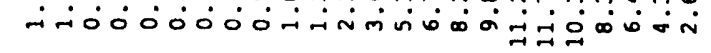

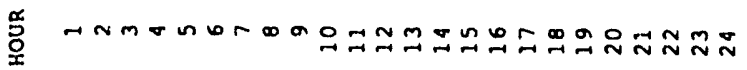




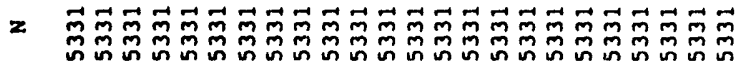

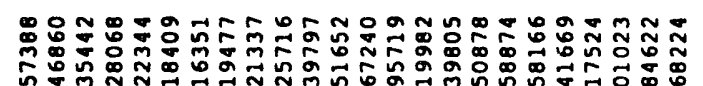

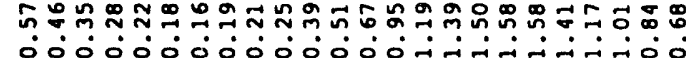

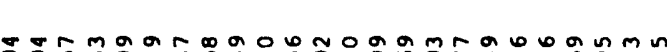

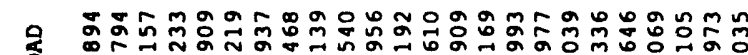

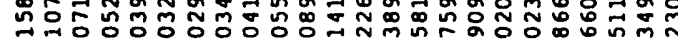

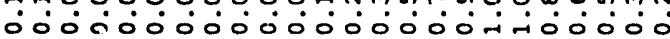
$\stackrel{0}{9}$

ดำฝัธ์

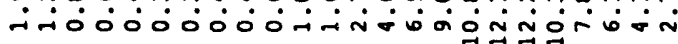

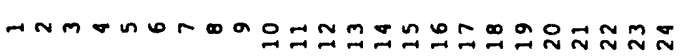

$z$

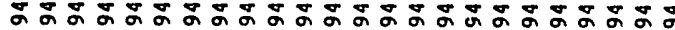

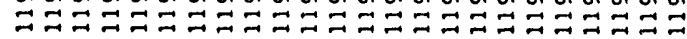

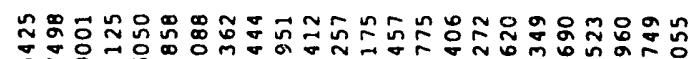

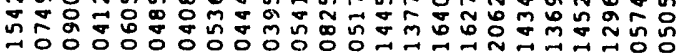

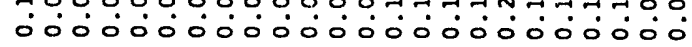

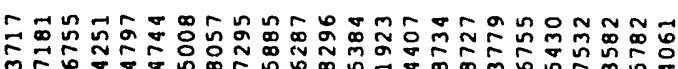

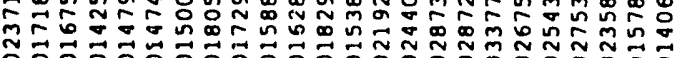

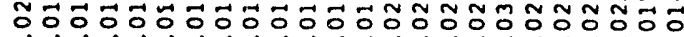
o00000000000000000000000

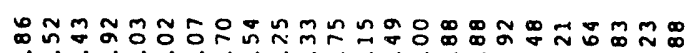

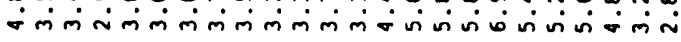

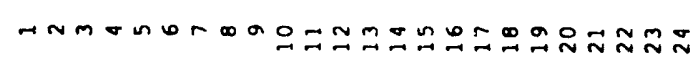

$$
\text { 管 }
$$$$
\text { ח }
$$

乙

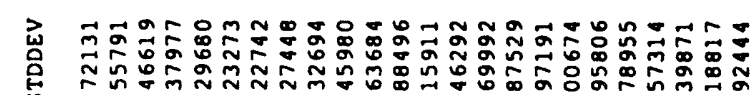
000000000000

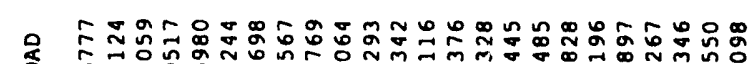

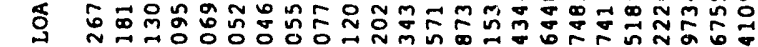
: 00000000000000 $\lambda$

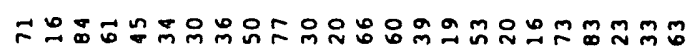

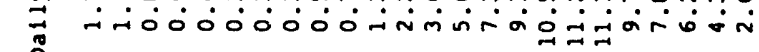

웅 
$z \tilde{m} \tilde{m} \tilde{m} \tilde{m} \tilde{m} \tilde{m} \tilde{m} \tilde{m} \tilde{m} \tilde{m} \tilde{m} \tilde{m} \tilde{m} \tilde{m} \tilde{m} \tilde{m} \tilde{m} \tilde{m}$

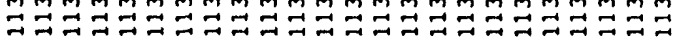

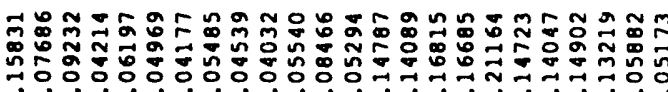

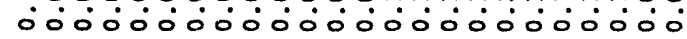

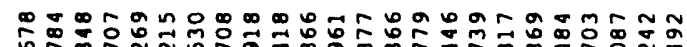

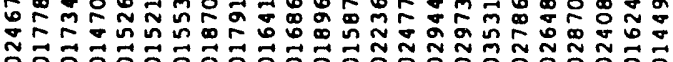

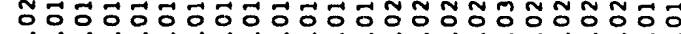
000000000000000000000000

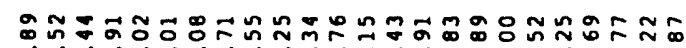

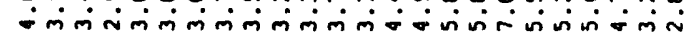

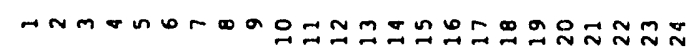
온

2

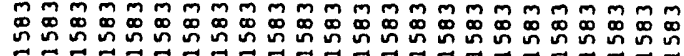

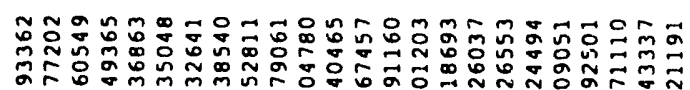
000000000ன்

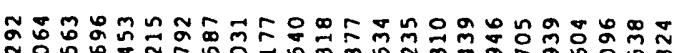

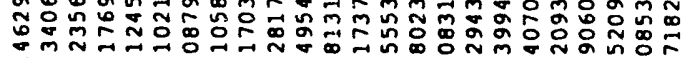

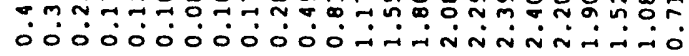
i

ดิ

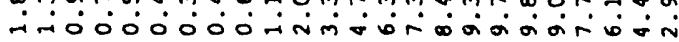

ํㅗㅇ

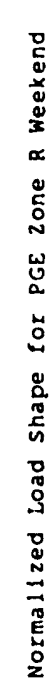

$z$

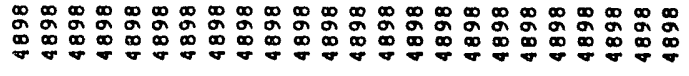

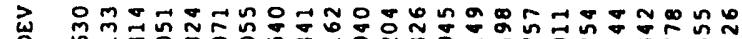

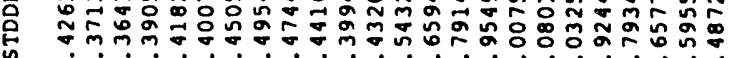

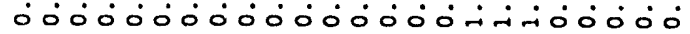

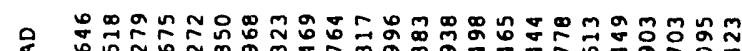

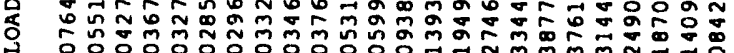

:

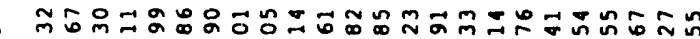

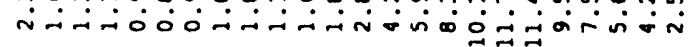

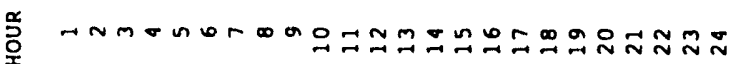

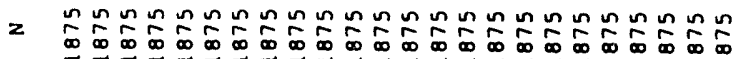

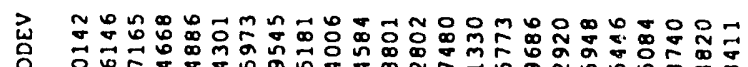

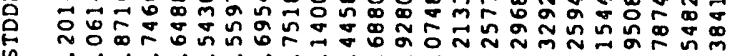

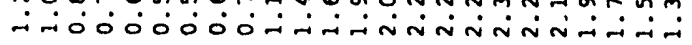

㟧

s.

离

$\stackrel{\pi}{\circ}$

D

110

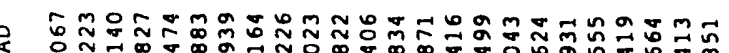

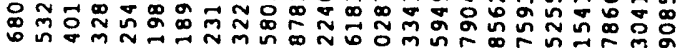

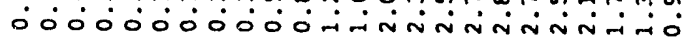

:

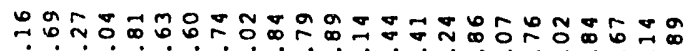

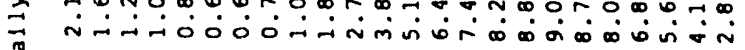

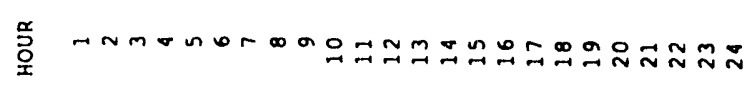




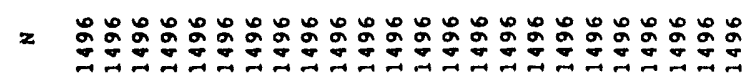

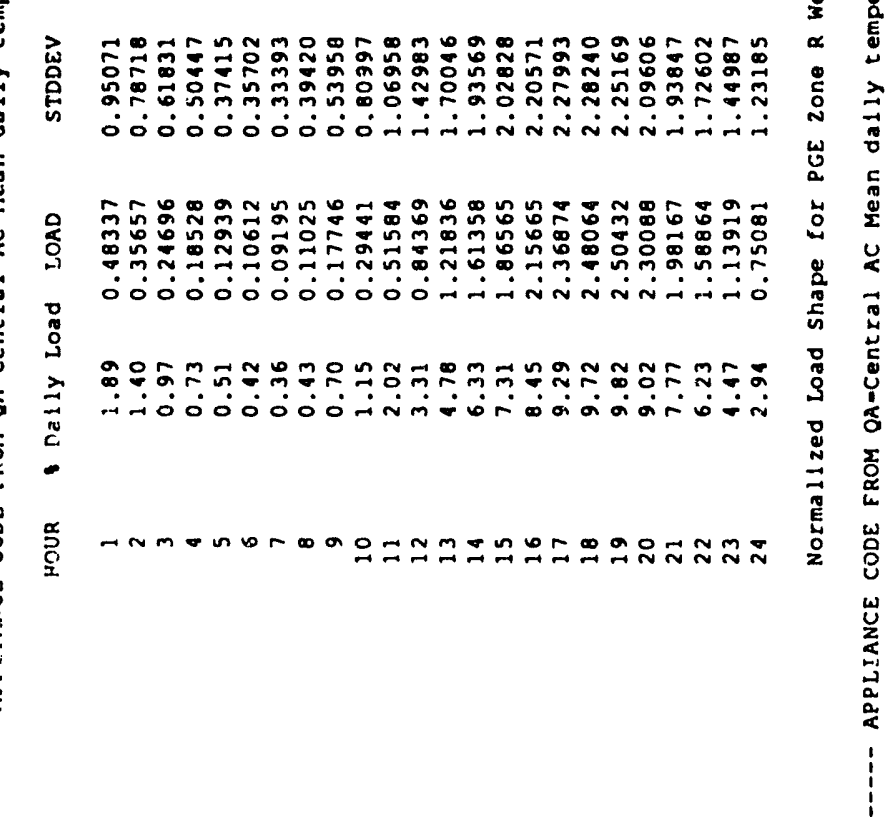

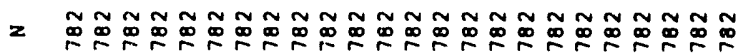

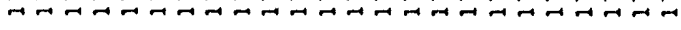

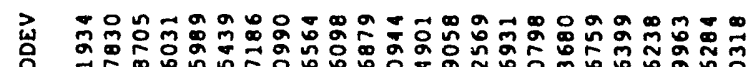

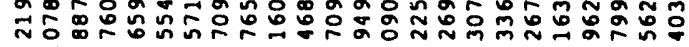

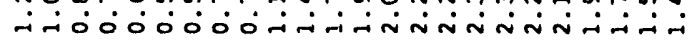

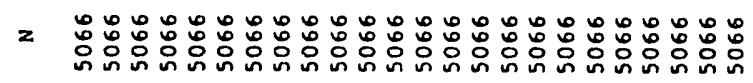

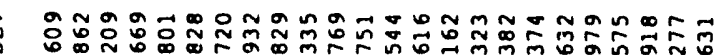

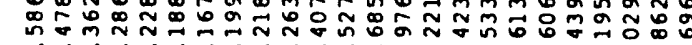

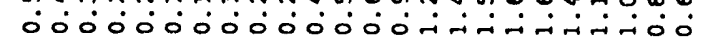

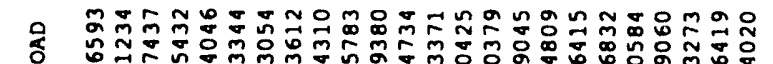

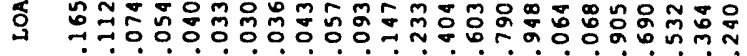
:

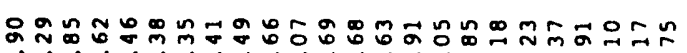
I

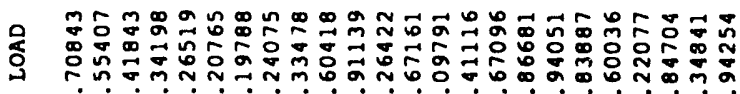

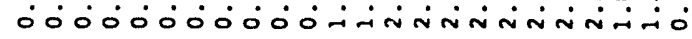

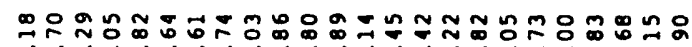

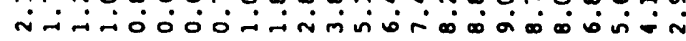

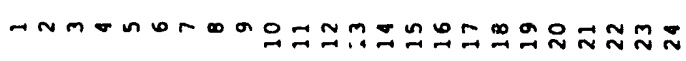

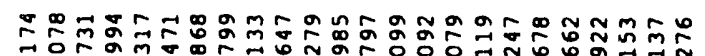

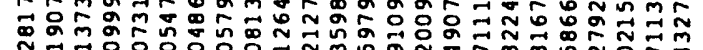

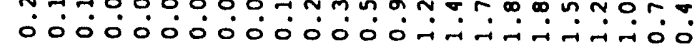
范

入

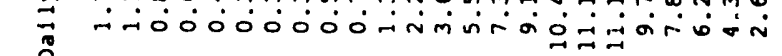

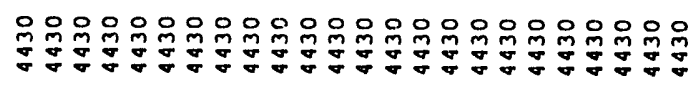

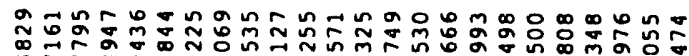

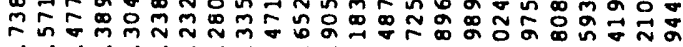
00000

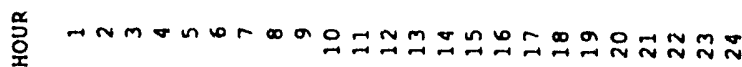




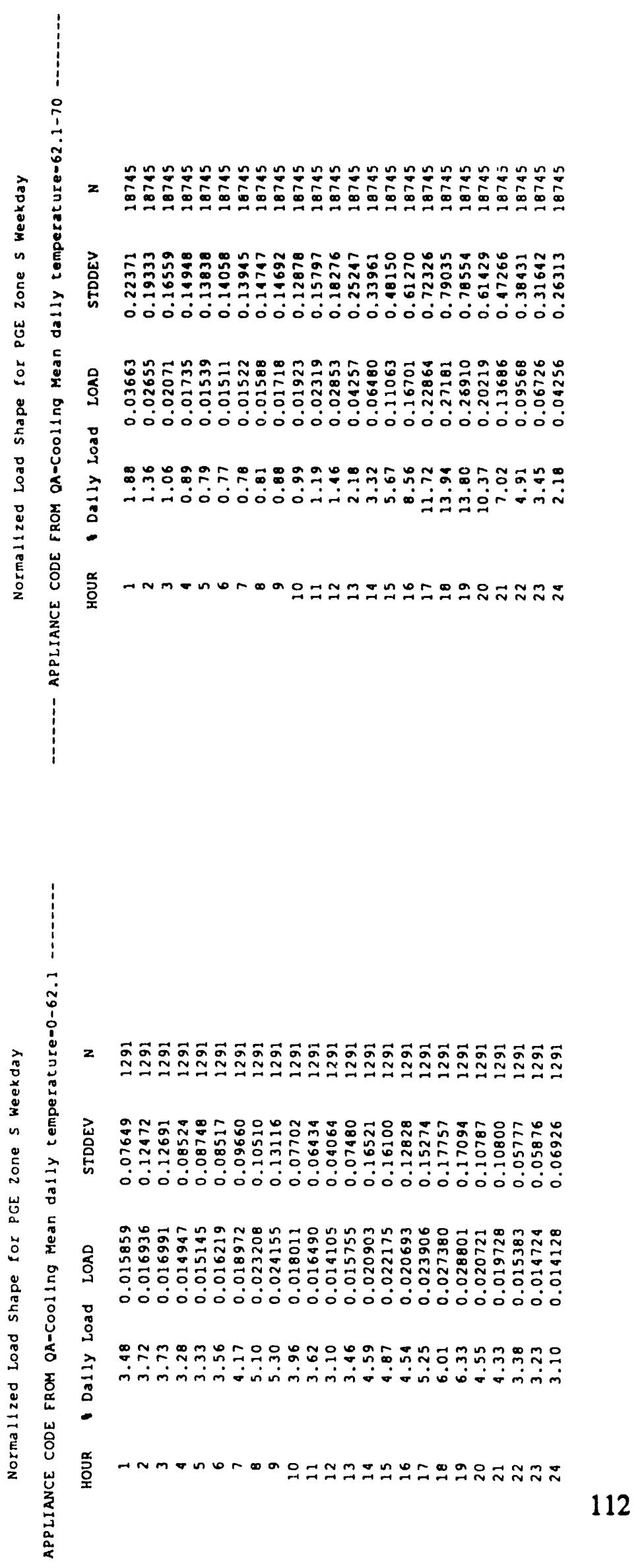




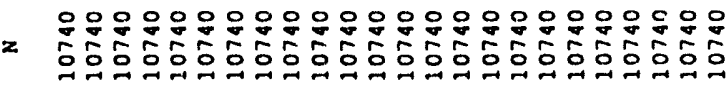

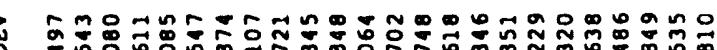

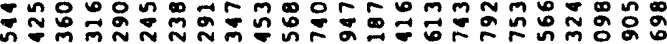
000000000000

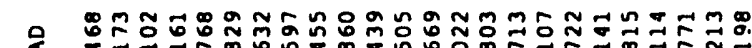

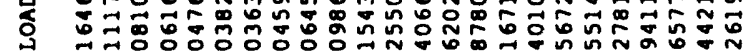

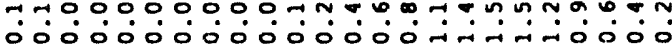
i

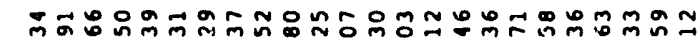

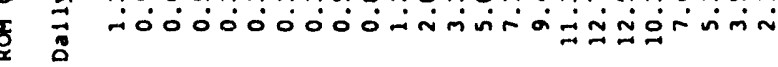

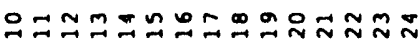

$z$ ด์

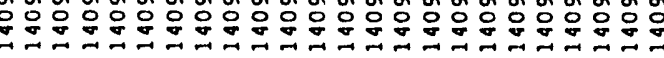

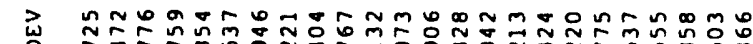

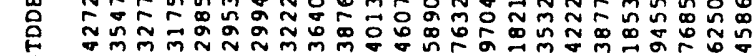
क

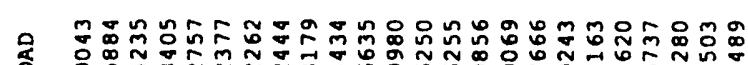

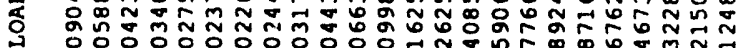

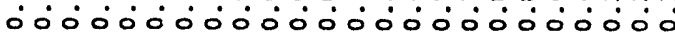
\%

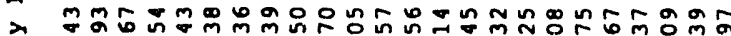

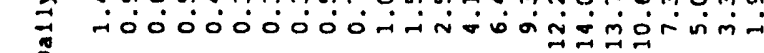
क्ष

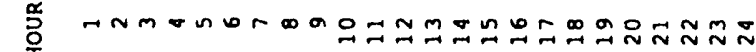




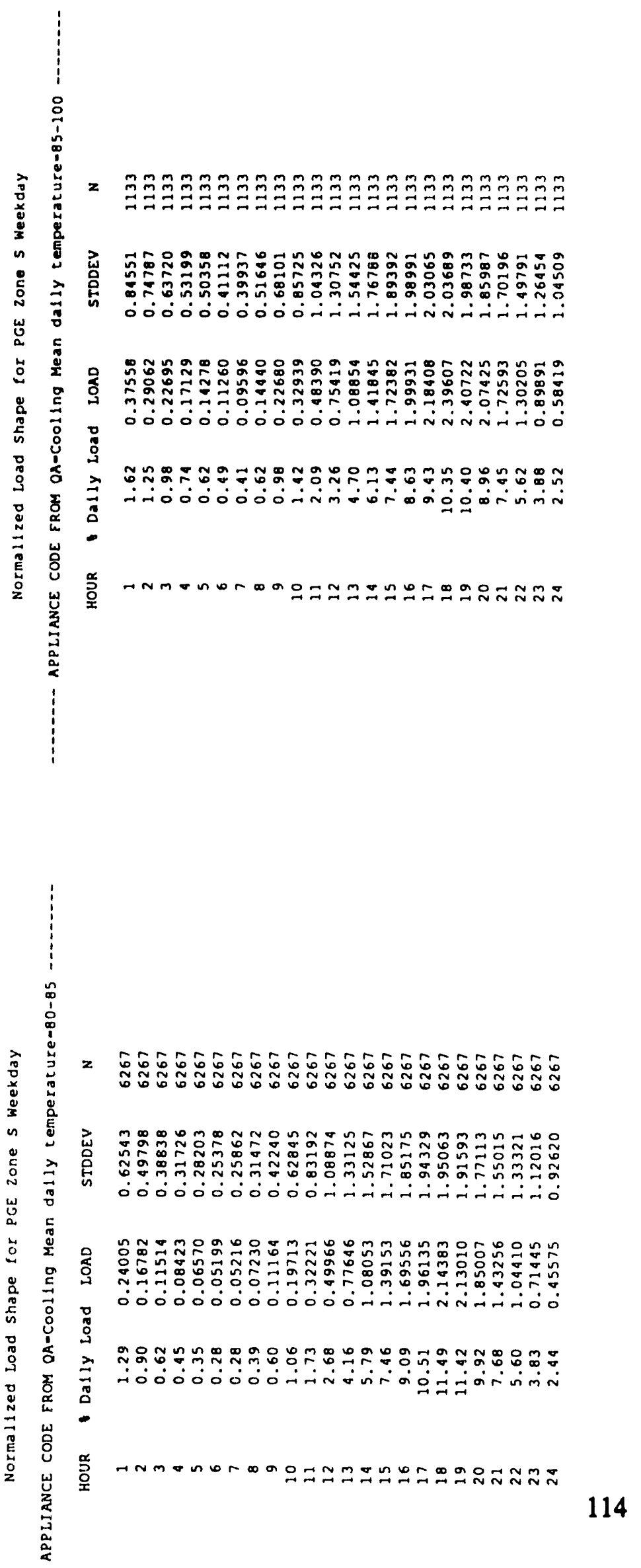




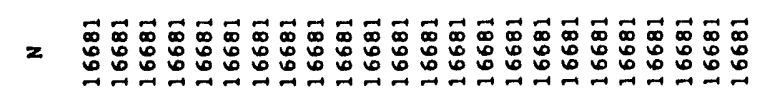

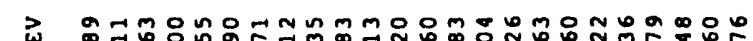

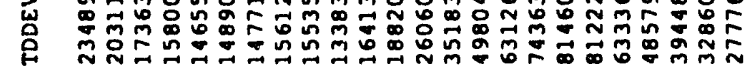
o00000000000000000000

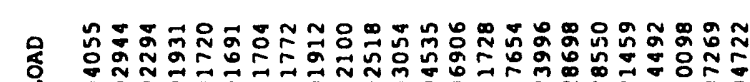

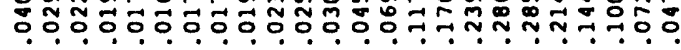
000000000000000000000000 :

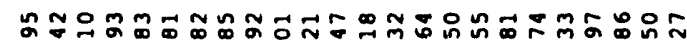

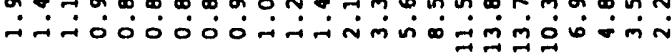

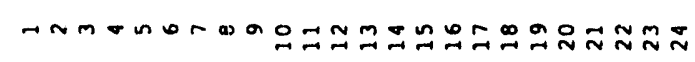

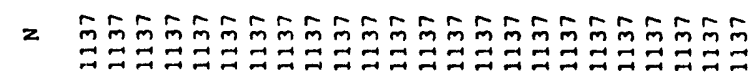

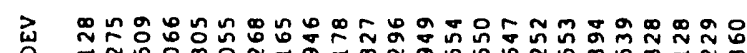

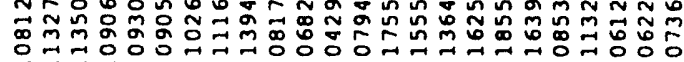

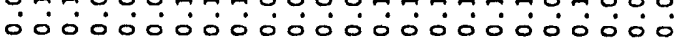

岁

ชึ

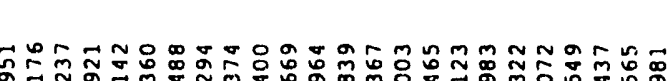

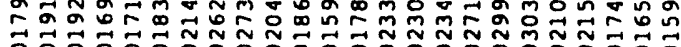

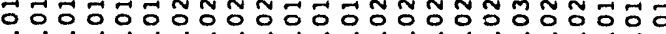
-00000000000000000000

ธำ

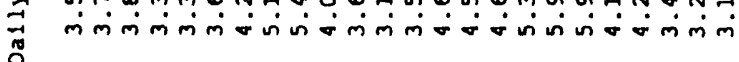

$\Sigma$

잉

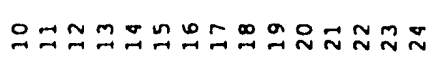




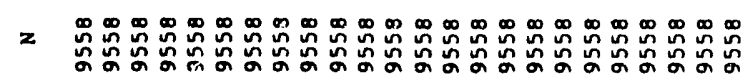

药

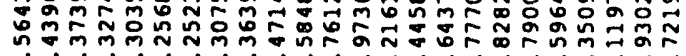

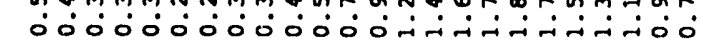

岁

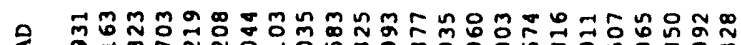

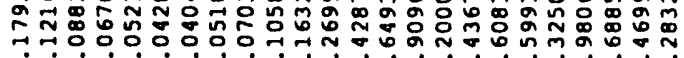

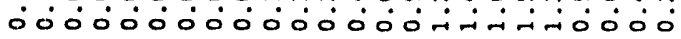
:

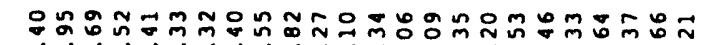

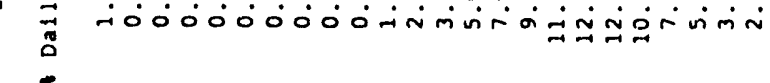

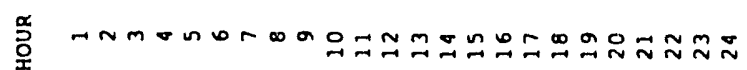

พ

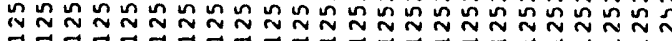

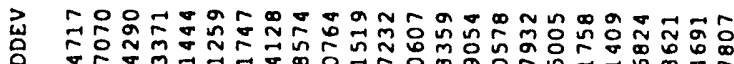

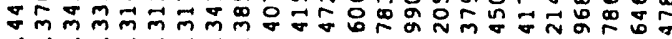

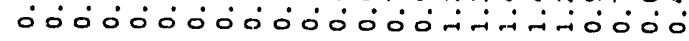

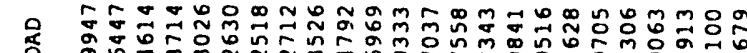

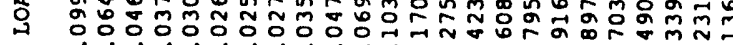
000000000000000000000000 o

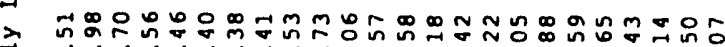

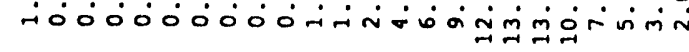



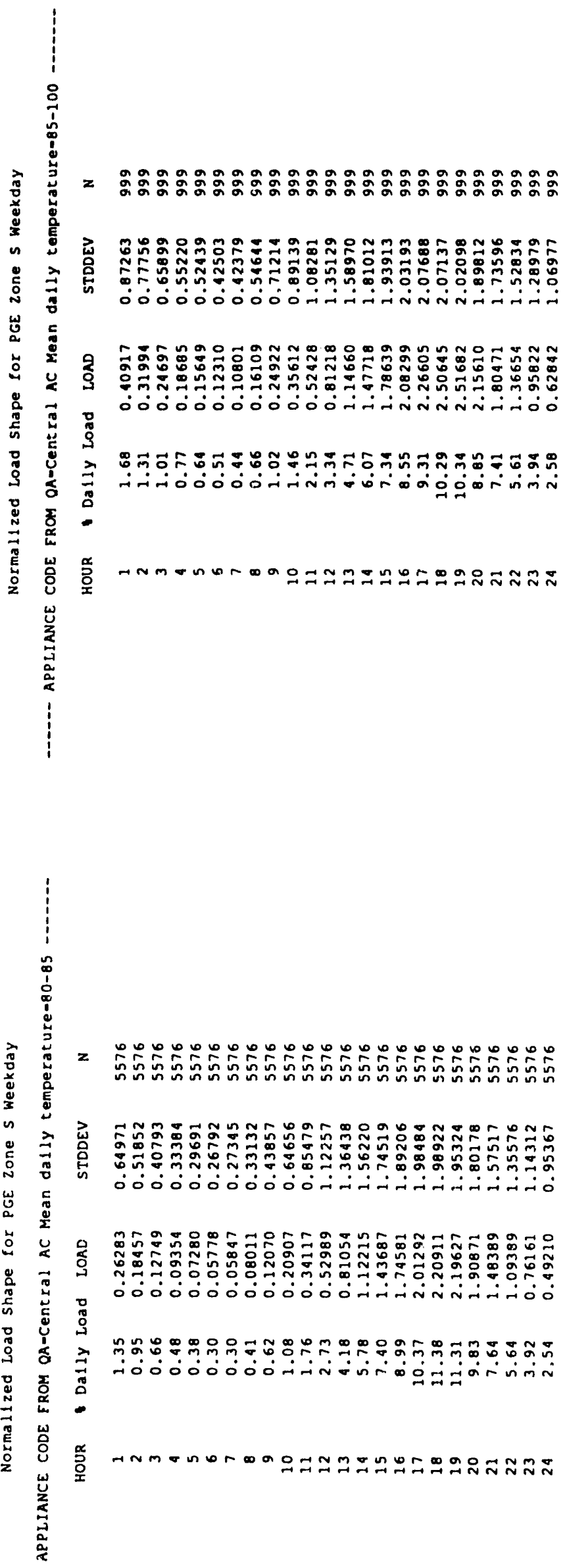
$=000000000000000000000000$

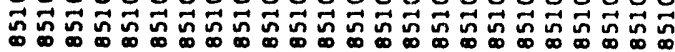

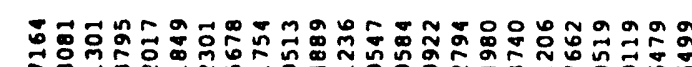

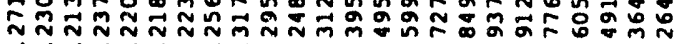

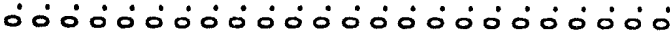

ํㅗำ

2

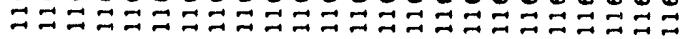

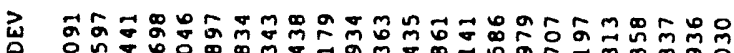

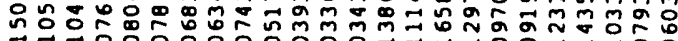

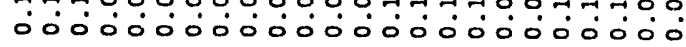

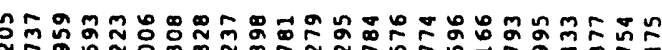

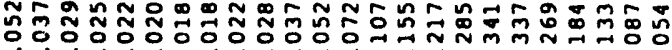
-00000000000000000000000

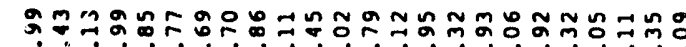
AN

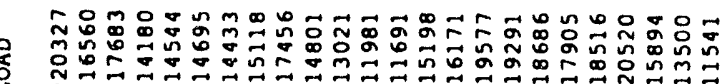

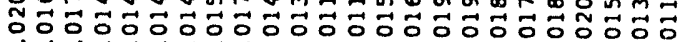

:

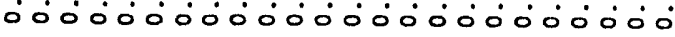

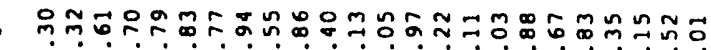

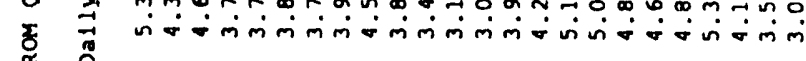




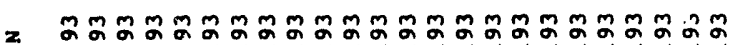

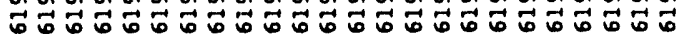

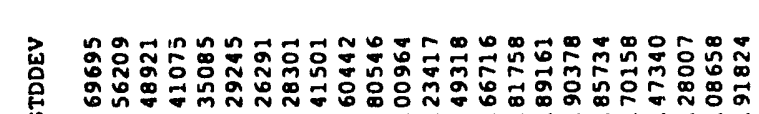
ํํำ

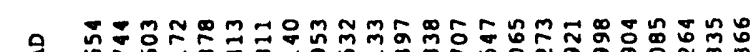

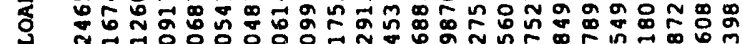
:

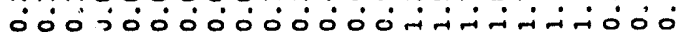

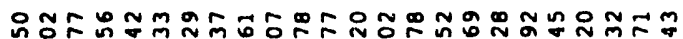

=

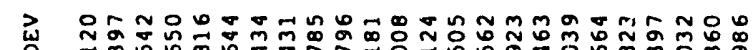

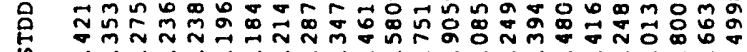

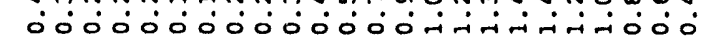

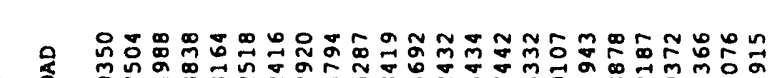

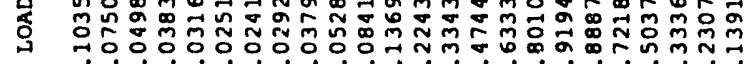

: 000000000000000000050000

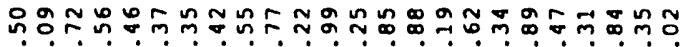

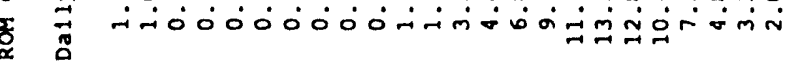

岁

옹 


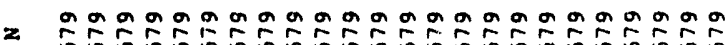

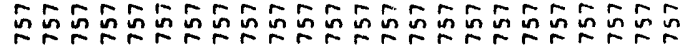

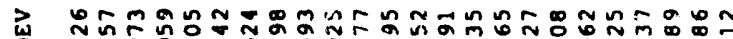

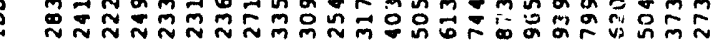
000000000000000000000

岁

จ

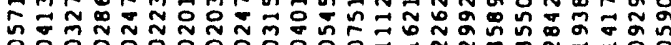
ó0000000000000000 $\stackrel{8}{3}$

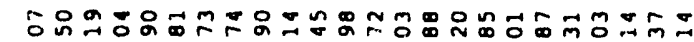

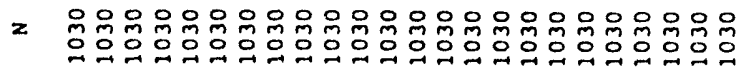

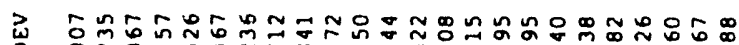

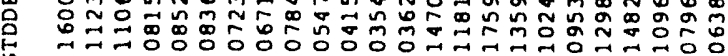

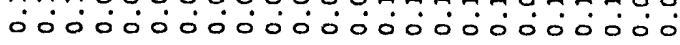

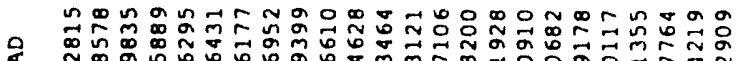
స

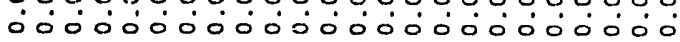
:

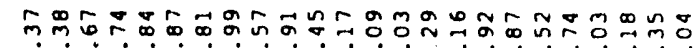

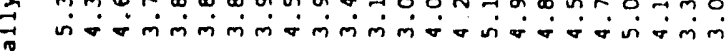

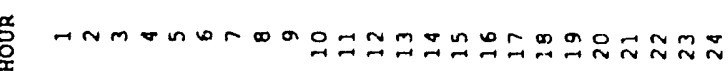




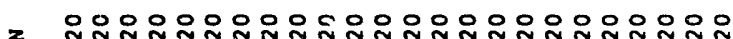
ถิ๊

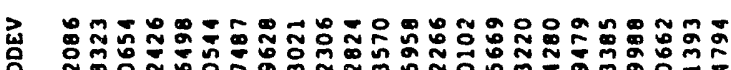

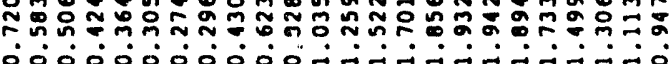

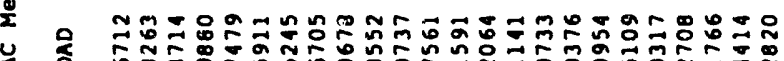

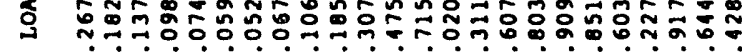

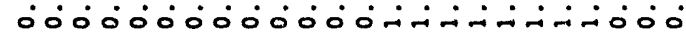

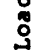

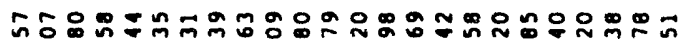

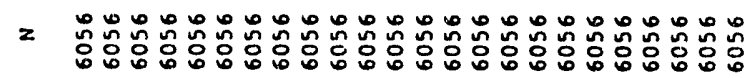

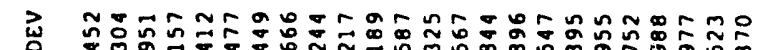

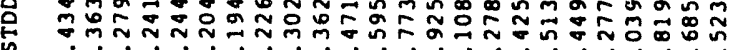

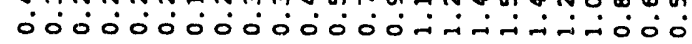

范

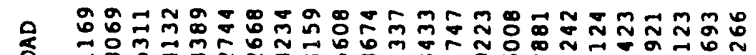

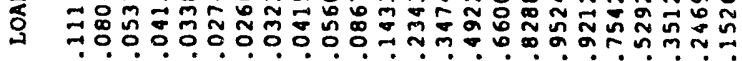

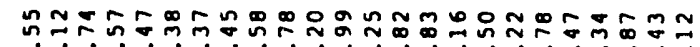

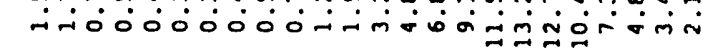

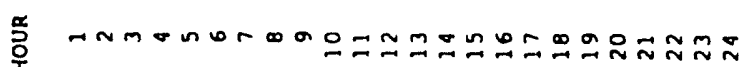




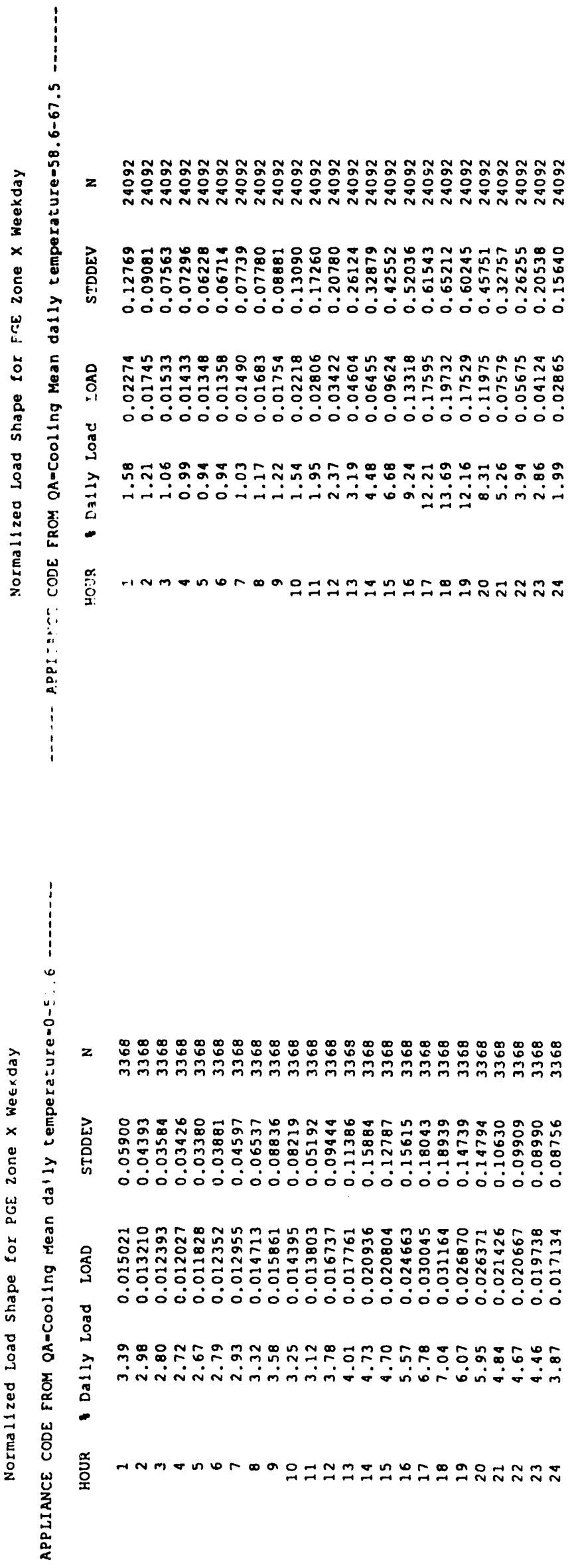



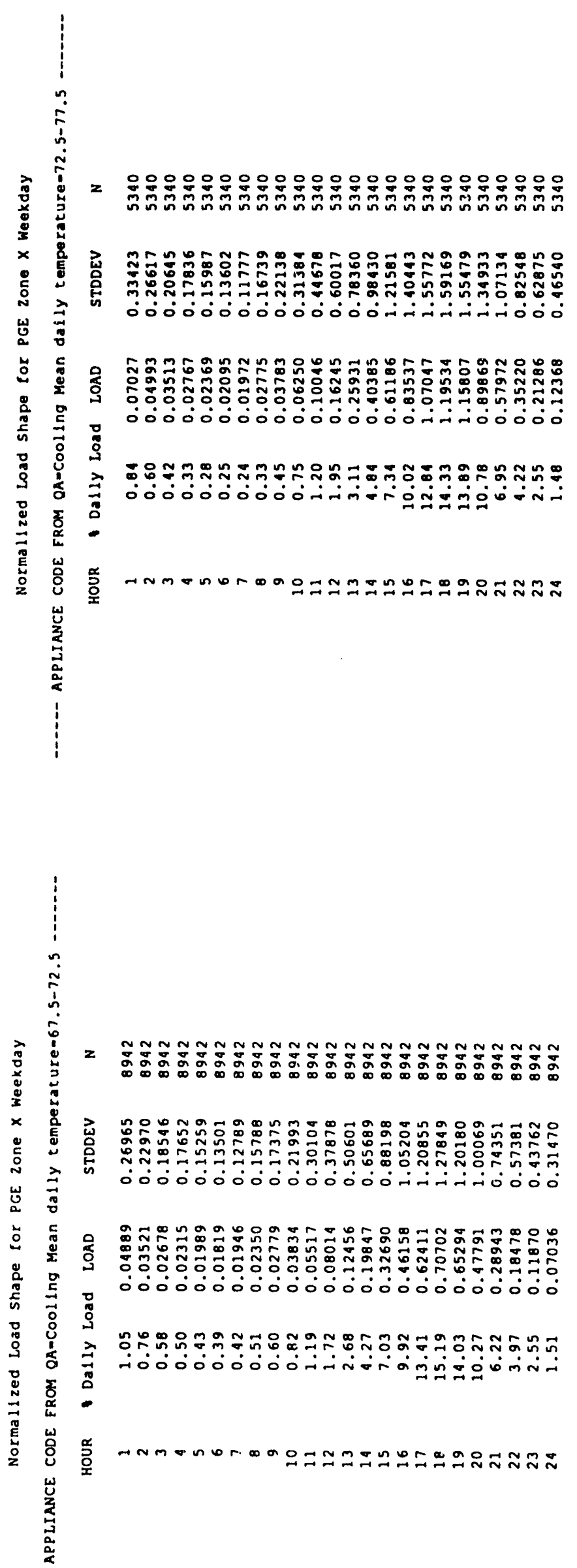


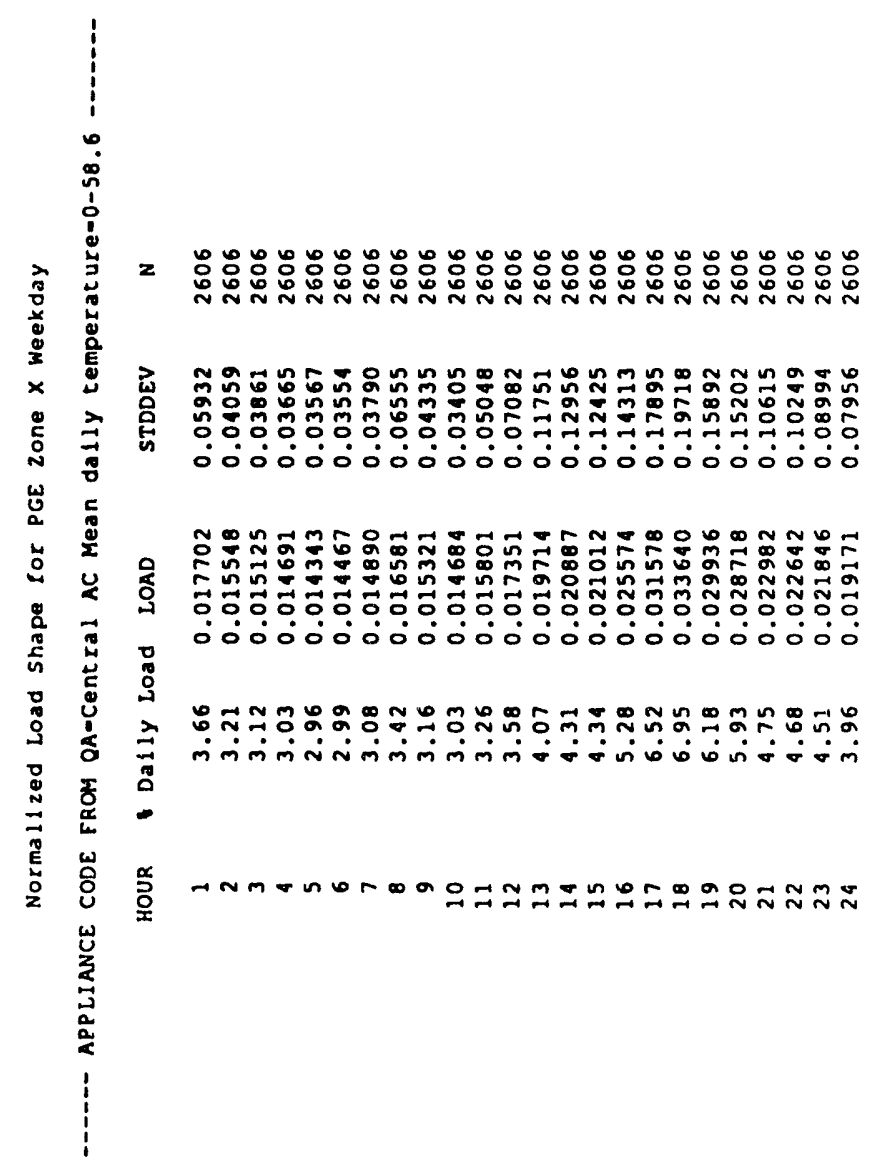

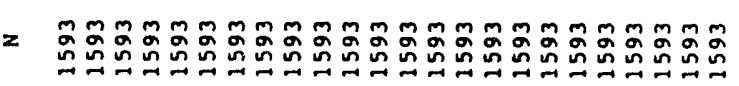



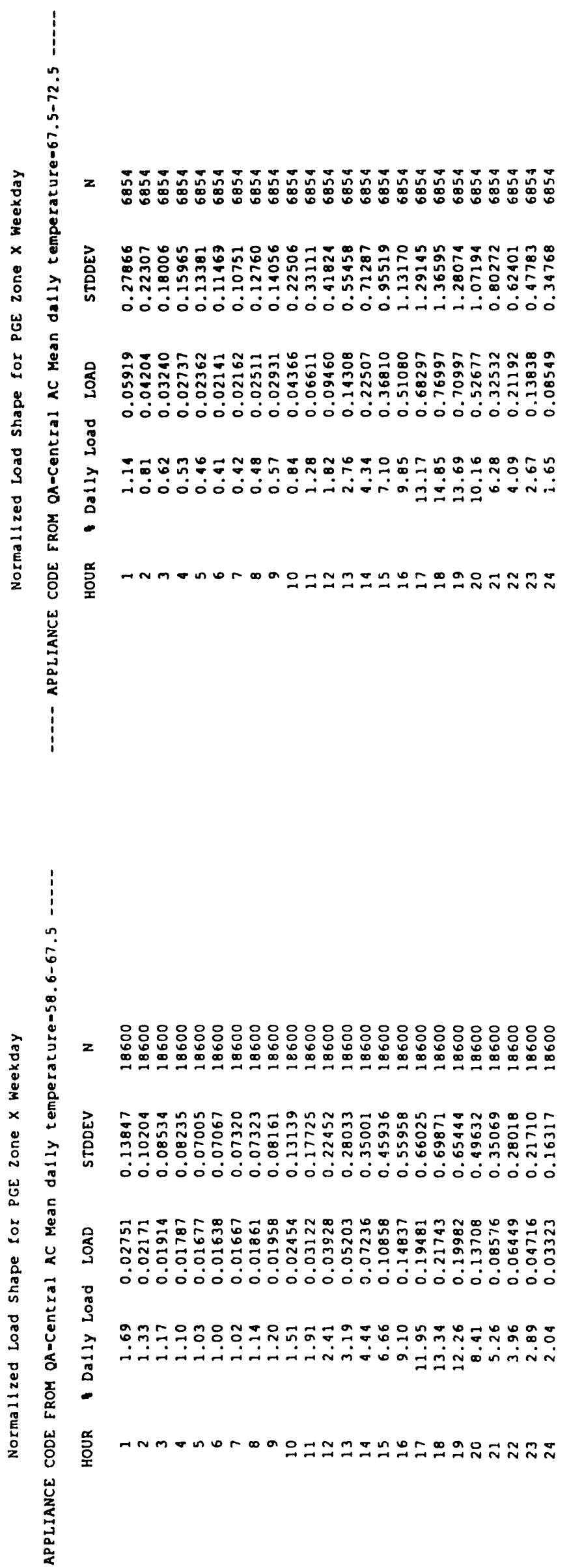


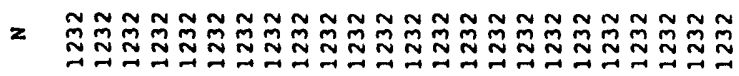

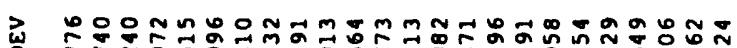

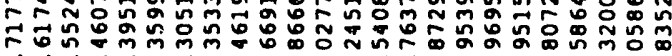

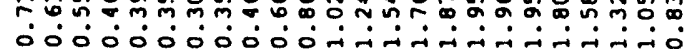

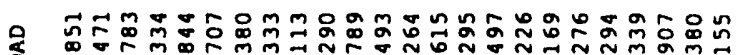

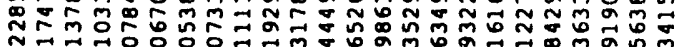

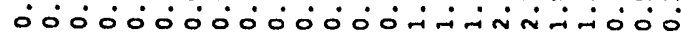

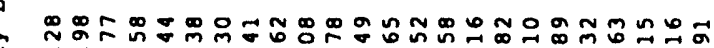

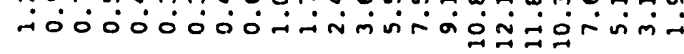

尊

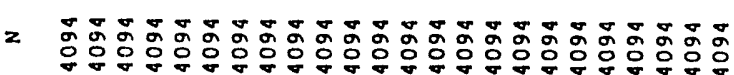

认

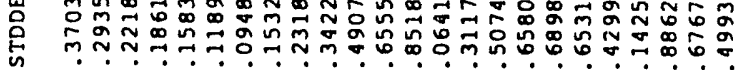

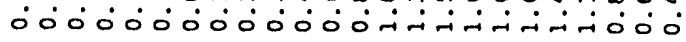

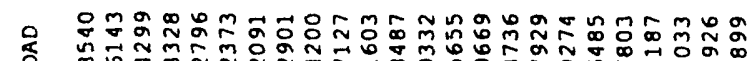

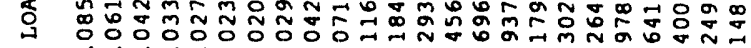

:

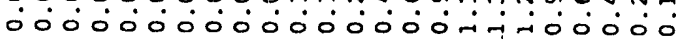

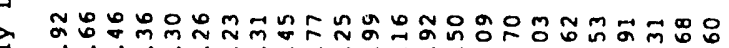

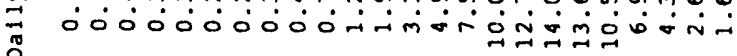

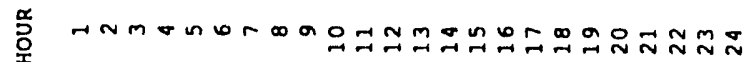




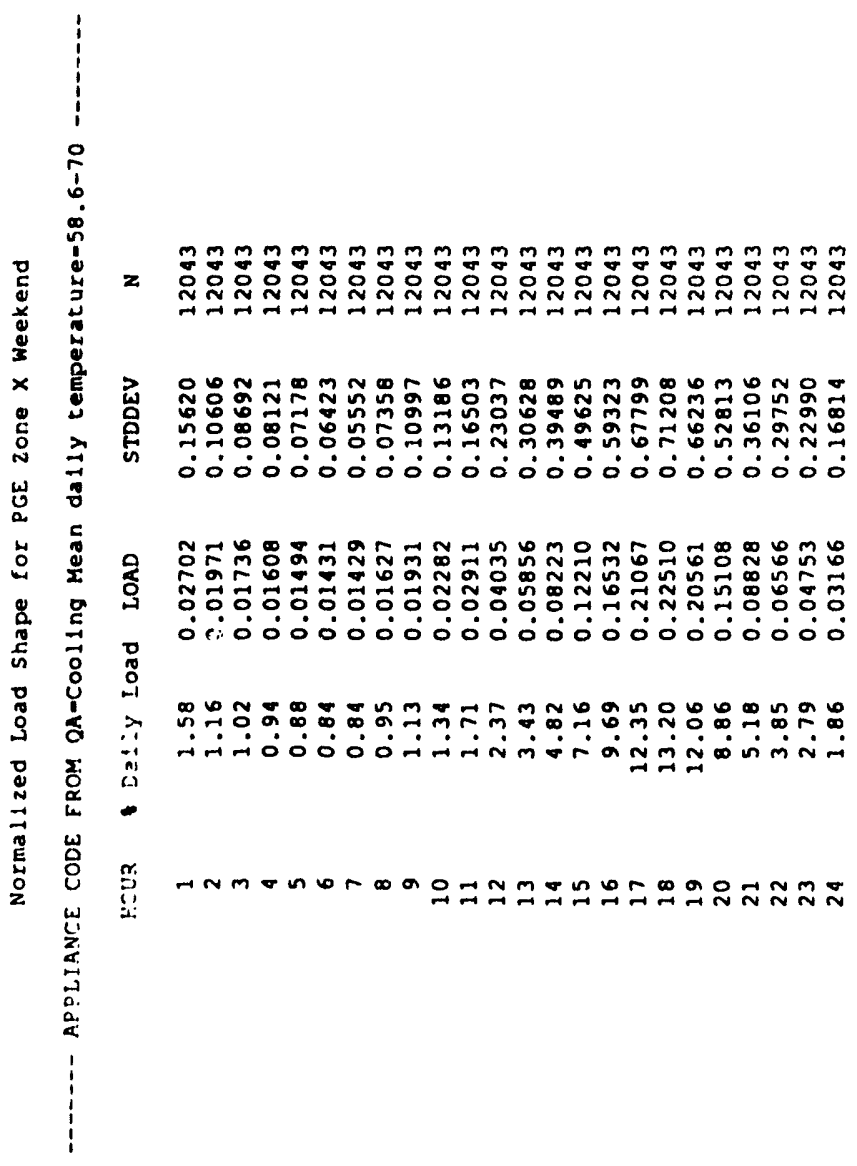

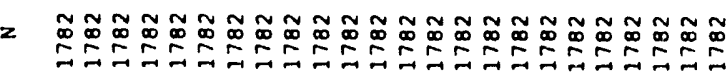

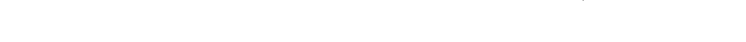

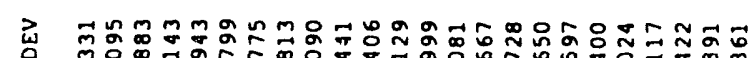

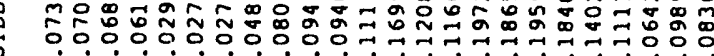

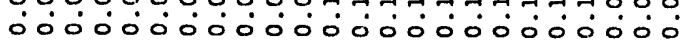

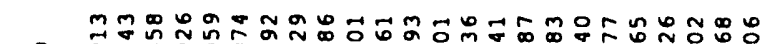
๙

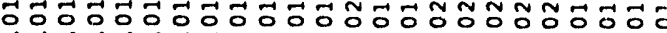
óo00000000000000000000 $\stackrel{0}{9}$

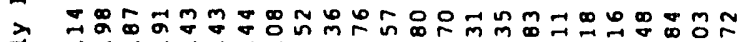

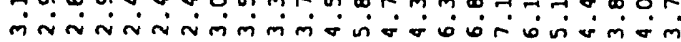




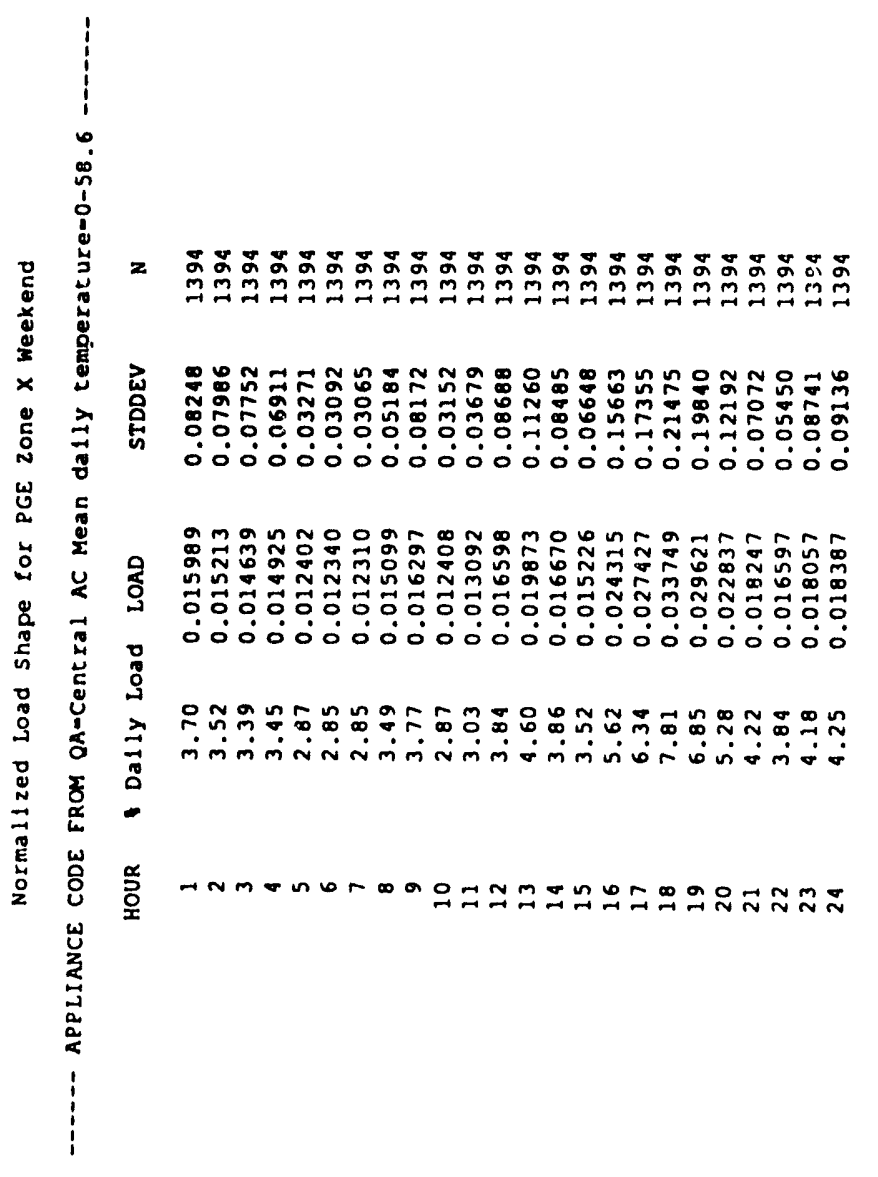

工

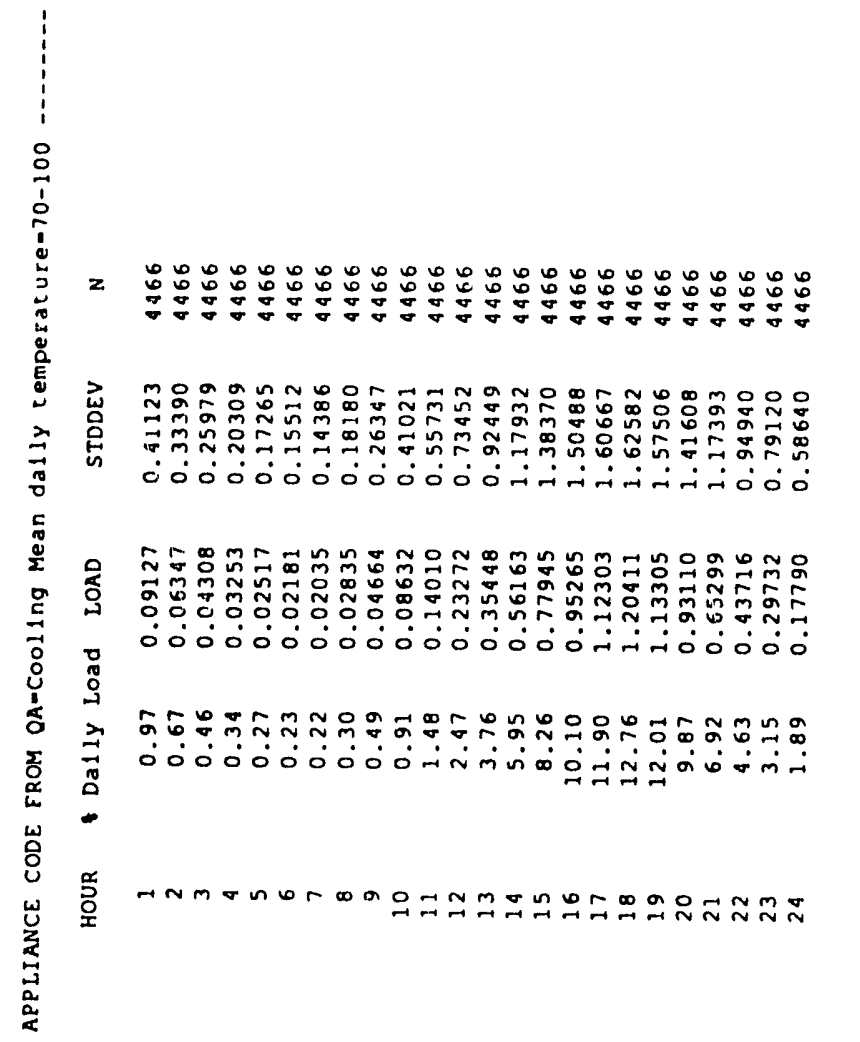




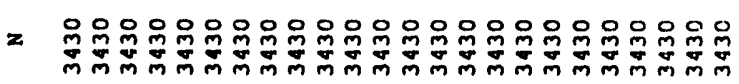

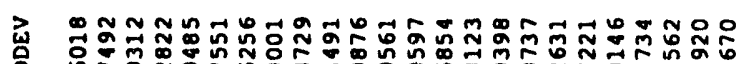

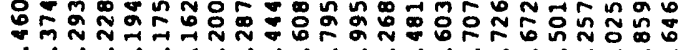

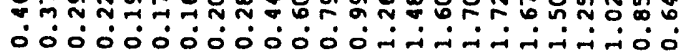

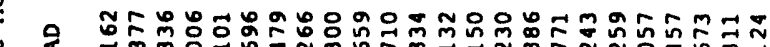

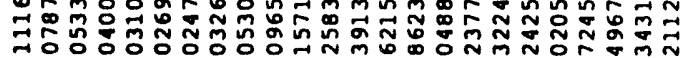

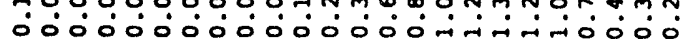

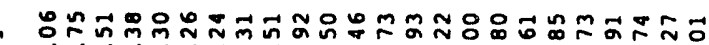
$\exists$ - 000000000 -

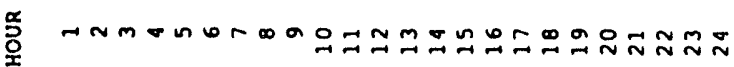

势

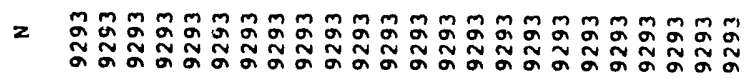

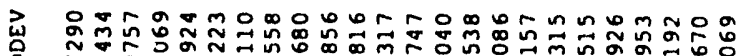

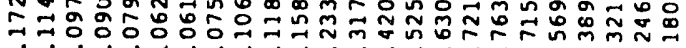
- ó0ं0́丶0

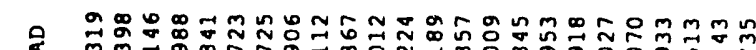
MN

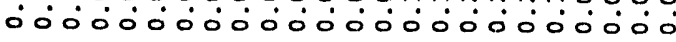
:

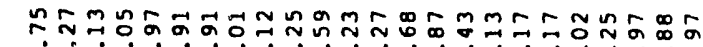

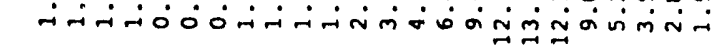




\section{Appendix E \\ Data Tables for Chapter 7}


Table E-1

Monthly Allocation Factors Non-Conditioning End Uses

\begin{tabular}{|c|c|c|c|c|}
\hline SEASON & WEEKDAY & WEEKEND & ALL DAYS & WEEKDA YIWEEKEND \\
\hline 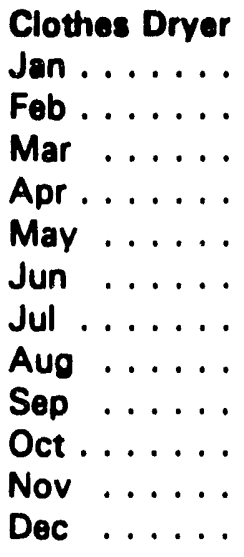 & $\begin{array}{l}1.101 \\
1.022 \\
0.996 \\
0.900 \\
0.876 \\
0.873 \\
0.815 \\
0.810 \\
0.836 \\
0.882 \\
0.972 \\
1.088\end{array}$ & $\begin{array}{l}1.410 \\
1.369 \\
1.302 \\
1.164 \\
1.082 \\
0.978 \\
0.901 \\
0.937 \\
1.105 \\
1.167 \\
1.207 \\
1.323\end{array}$ & $\begin{array}{l}1.191 \\
1.134 \\
1.088 \\
0.977 \\
0.937 \\
0.882 \\
0.842 \\
0.847 \\
0.923 \\
0.958 \\
1.028 \\
1.163\end{array}$ & $\begin{array}{l}0.781 \\
0.746 \\
0.765 \\
0.774 \\
0.809 \\
0.848 \\
0.905 \\
0.864 \\
0.757 \\
0.756 \\
0.805 \\
0.823\end{array}$ \\
\hline $\begin{array}{l}\text { Cooking } \\
\text { Jan } \ldots \ldots \\
\text { Feb } \ldots \ldots \\
\text { Mar } \ldots \ldots \\
\text { Apr } \ldots \ldots \\
\text { May } \ldots \ldots \\
\text { Jun } \ldots \ldots \\
\text { Jul } \ldots \ldots \\
\text { Aug } \ldots \ldots \\
\text { Sep } \ldots \ldots \\
\text { Oct } \ldots \ldots \\
\text { Nov } \ldots \ldots \\
\text { Dec } \ldots \ldots \\
\end{array}$ & $\begin{array}{l}1.052 \\
0.994 \\
1.010 \\
0.930 \\
0.880 \\
0.829 \\
0.865 \\
0.907 \\
0.918 \\
0.947 \\
1.015 \\
1.058\end{array}$ & $\begin{array}{l}1.230 \\
1.171 \\
1.205 \\
1.063 \\
0.984 \\
0.922 \\
0.923 \\
0.950 \\
1.061 \\
1.104 \\
1.310 \\
1.356\end{array}$ & $\begin{array}{l}1.103 \\
1.051 \\
1.068 \\
0.968 \\
0.911 \\
0.857 \\
0.883 \\
0.919 \\
0.964 \\
0.989 \\
1.124 \\
1.153\end{array}$ & $\begin{array}{l}0.855 \\
0.849 \\
0.838 \\
0.875 \\
0.894 \\
0.898 \\
0.938 \\
0.955 \\
0.865 \\
0.857 \\
0.775 \\
0.780\end{array}$ \\
\hline
\end{tabular}


Table E-1 continued

\begin{tabular}{|c|c|c|c|c|}
\hline SEASON & WEEKDAY & WEEKEND & ALL DAYS & WEEKDAYYWEEKEND \\
\hline $\begin{array}{l}\text { Kitchen Circuit } \\
\text { Jan } \ldots \ldots \\
\text { Fob } \ldots \ldots \\
\text { Mar } \ldots \ldots \\
\text { Apr } \ldots \ldots \\
\text { May } \ldots \ldots \\
\text { Jun } \ldots \ldots \\
\text { Jul } \ldots \ldots \\
\text { Aug } \ldots \ldots \\
\text { Sep } \ldots \ldots \\
\text { Oct } \ldots \ldots \\
\text { Nov } \ldots \ldots \\
\text { Dec } \ldots \ldots \\
\end{array}$ & $\begin{array}{l}0.975 \\
0.966 \\
0.953 \\
0.985 \\
0.971 \\
1.050 \\
1.092 \\
1.052 \\
1.031 \\
0.985 \\
0.943 \\
0.931\end{array}$ & $\begin{array}{l}1.001 \\
0.983 \\
0.981 \\
1.008 \\
0.998 \\
1.056 \\
1.087 \\
1.066 \\
1.051 \\
1.017 \\
0.976 \\
0.950\end{array}$ & $\begin{array}{l}0.982 \\
0.972 \\
0.962 \\
0.991 \\
0.979 \\
1.052 \\
1.091 \\
1.056 \\
1.038 \\
0.994 \\
0.956 \\
0.937\end{array}$ & $\begin{array}{l}0.974 \\
0.982 \\
0.972 \\
0.977 \\
0.973 \\
0.995 \\
1.005 \\
0.987 \\
0.981 \\
0.969 \\
0.966 \\
0.980\end{array}$ \\
\hline $\begin{array}{l}\text { Refrigerator } \\
\text { Jan } \ldots \ldots \\
\text { Feb } \ldots \ldots \\
\text { Mar } \ldots \ldots \\
\text { Apr } \ldots \ldots \\
\text { May } \ldots \ldots \\
\text { Jun } \ldots \ldots \\
\text { Jul } \ldots \ldots \\
\text { Aug } \ldots \ldots \\
\text { Sep } \ldots \ldots \\
\text { Oct } \ldots \ldots \\
\text { Nov } \ldots \ldots \\
\text { Dec } \ldots \ldots \\
\end{array}$ & $\begin{array}{l}0.846 \\
0.862 \\
0.900 \\
0.971 \\
0.985 \\
1.133 \\
1.117 \\
1.130 \\
1.066 \\
1.014 \\
0.932 \\
0.926\end{array}$ & $\begin{array}{l}0.868 \\
0.883 \\
0.944 \\
1.002 \\
1.013 \\
1.117 \\
1.122 \\
1.160 \\
1.118 \\
1.029 \\
0.976 \\
0.939\end{array}$ & $\begin{array}{l}0.852 \\
0.869 \\
0.913 \\
0.980 \\
0.994 \\
1.128 \\
1.119 \\
1.139 \\
1.082 \\
1.018 \\
0.948 \\
0.930\end{array}$ & $\begin{array}{l}0.975 \\
0.977 \\
0.954 \\
0.969 \\
0.972 \\
1.015 \\
0.996 \\
0.974 \\
0.954 \\
0.985 \\
0.955 \\
0.987\end{array}$ \\
\hline $\begin{array}{l}\text { Water Heater } \\
\text { Jan } \ldots \ldots \\
\text { Feb } \ldots \ldots \\
\text { Mar } \ldots \ldots \\
\text { Apr } \ldots \ldots \\
\text { May } \ldots \ldots \\
\text { Jun } \ldots \ldots \\
\text { Jul } \ldots \ldots \\
\text { Aug } \ldots \ldots \\
\text { Sep } \ldots \ldots \\
\text { Oct } \ldots \ldots \\
\text { Nov } \ldots \ldots \\
\text { Dec } \ldots \ldots \\
\end{array}$ & $\begin{array}{l}1.258 \\
1.208 \\
1.139 \\
1.015 \\
0.944 \\
0.819 \\
0.745 \\
0.749 \\
0.857 \\
0.943 \\
1.077 \\
1.174\end{array}$ & $\begin{array}{l}1.287 \\
1.243 \\
1.181 \\
1.037 \\
0.941 \\
0.817 \\
0.772 \\
0.753 \\
0.854 \\
0.956 \\
1.114 \\
1.199\end{array}$ & $\begin{array}{l}1.267 \\
1.220 \\
1.151 \\
1.021 \\
0.943 \\
0.819 \\
0.754 \\
0.750 \\
0.856 \\
0.947 \\
1.090 \\
1.182\end{array}$ & $\begin{array}{l}0.977 \\
0.972 \\
0.964 \\
0.979 \\
1.003 \\
1.002 \\
0.966 \\
0.995 \\
1.004 \\
0.986 \\
0.967 \\
0.979\end{array}$ \\
\hline
\end{tabular}


Average Daily Load Shapes by Season and Day Type

Percent of Total Daily Energy

APPLIANCE CODE FROM QA=Clothes Dryer

$\begin{array}{rrrrr}\text { Hour } & \begin{array}{l}\text { Winter } \\ \text { Weekend }\end{array} & \begin{array}{l}\text { Winter } \\ \text { Weekday }\end{array} & \begin{array}{c}\text { Summer } \\ \text { Weekend }\end{array} & \begin{array}{c}\text { Summer } \\ \text { Weekday }\end{array} \\ 1 & 0.71 & 0.93 & 0.87 & 0.99 \\ 2 & 0.38 & 0.41 & 0.42 & 0.42 \\ 3 & 0.21 & 0.25 & 0.24 & 0.25 \\ 4 & 0.13 & 0.16 & 0.17 & 0.20 \\ 5 & 0.12 & 0.20 & 0.15 & 0.24 \\ 6 & 0.21 & 0.59 & 0.27 & 0.57 \\ 7 & 0.51 & 2.08 & 0.57 & 1.94 \\ 8 & 1.52 & 3.89 & 1.73 & 3.87 \\ 9 & 3.49 & 5.48 & 3.84 & 5.69 \\ 10 & 5.92 & 7.08 & 6.11 & 7.19 \\ 11 & 7.83 & 7.88 & 7.99 & 8.22 \\ 12 & 8.92 & 7.91 & 8.90 & 8.27 \\ 13 & 8.93 & 7.10 & 8.84 & 7.09 \\ 14 & 8.21 & 6.03 & 8.10 & 5.96 \\ 15 & 7.59 & 5.57 & 6.99 & 5.29 \\ 16 & 7.05 & 5.61 & 6.26 & 5.19 \\ 17 & 6.76 & 5.67 & 6.07 & 5.32 \\ 18 & 6.50 & 5.73 & 5.95 & 5.40 \\ 19 & 5.78 & 5.68 & 5.66 & 5.49 \\ 20 & 5.37 & 5.47 & 5.33 & 5.28 \\ 21 & 4.90 & 5.45 & 5.28 & 5.44 \\ 22 & 4.19 & 5.14 & 4.85 & 5.29 \\ 23 & 3.00 & 3.66 & 3.47 & 4.08 \\ 24 & 1.76 & 2.02 & 1.95 & 2.31\end{array}$

Summer is June through October. winter is November through May. 
Average Daily Load Shapes by Season and Day Type

Percent of Total Daily Energy

APPLIANCE CODE FROM QA=Refrigerator

$\begin{array}{rrrrr}\text { Hour } & \begin{array}{l}\text { Winter } \\ \text { Weekend }\end{array} & \begin{array}{l}\text { Winter } \\ \text { Weekday }\end{array} & \begin{array}{c}\text { Summer } \\ \text { Weekend }\end{array} & \begin{array}{c}\text { Summer } \\ \text { Weekday }\end{array} \\ 1 & 3.81 & 3.80 & 4.04 & 4.01 \\ 2 & 3.65 & 3.65 & 3.84 & 3.80 \\ 3 & 3.56 & 3.60 & 3.67 & 3.66 \\ 4 & 3.56 & 3.58 & 3.59 & 3.60 \\ 5 & 3.43 & 3.47 & 3.60 & 3.65 \\ 6 & 3.41 & 3.54 & 3.52 & 3.58 \\ 7 & 3.45 & 3.88 & 3.53 & 3.80 \\ 8 & 3.64 & 4.12 & 3.71 & 3.96 \\ 9 & 4.04 & 4.14 & 3.87 & 3.98 \\ 10 & 4.23 & 4.01 & 4.06 & 3.88 \\ 11 & 4.23 & 3.94 & 4.16 & 3.98 \\ 12 & 4.32 & 4.02 & 4.18 & 3.98 \\ 13 & 4.41 & 4.19 & 4.35 & 4.23 \\ 14 & 4.40 & 4.09 & 4.30 & 4.17 \\ 15 & 4.41 & 4.16 & 4.38 & 4.23 \\ 16 & 4.47 & 4.38 & 4.44 & 4.36 \\ 17 & 4.52 & 4.52 & 4.54 & 4.51 \\ 18 & 4.81 & 4.78 & 4.71 & 4.68 \\ 19 & 4.96 & 5.09 & 4.81 & 4.89 \\ 20 & 4.90 & 5.03 & 4.80 & 4.84 \\ 21 & 4.73 & 4.85 & 4.70 & 4.80 \\ 22 & 4.61 & 4.68 & 4.57 & 4.66 \\ 23 & 4.36 & 4.38 & 4.44 & 4.53 \\ 24 & 4.10 & 4.10 & 4.22 & 4.23 \\ & & & & \end{array}$

Summer is June through October.

winter is November through May. 
Average Daily Load Shapes by Season and Day Type

Percent of Total Daily Energy

APPLIANCE CODE FROM QA=water Heater

$\begin{array}{rrrrr}\text { Hour } & \begin{array}{l}\text { Winter } \\ \text { Weekend }\end{array} & \begin{array}{l}\text { Winter } \\ \text { Weekday }\end{array} & \begin{array}{c}\text { Summer } \\ \text { Weekend }\end{array} & \begin{array}{c}\text { Summer } \\ \text { Weekday }\end{array} \\ 1 & 1.57 & 1.43 & 1.64 & 1.46 \\ 2 & 1.14 & 1.06 & 1.15 & 1.06 \\ 3 & 0.98 & 0.95 & 0.97 & 1.02 \\ 4 & 1.04 & 1.11 & 1.06 & 1.18 \\ 5 & 1.74 & 1.99 & 1.64 & 1.91 \\ 6 & 2.96 & 4.21 & 3.04 & 4.10 \\ 7 & 3.49 & 7.72 & 3.85 & 7.78 \\ 8 & 5.28 & 9.26 & 5.22 & 8.46 \\ 9 & 7.19 & 8.07 & 7.22 & 8.00 \\ 10 & 7.34 & 6.03 & 7.53 & 6.55 \\ 11 & 6.37 & 4.71 & 6.44 & 5.09 \\ 12 & 5.42 & 3.68 & 5.39 & 4.00 \\ 13 & 4.75 & 3.32 & 4.72 & 3.50 \\ 14 & 4.26 & 3.17 & 4.47 & 3.47 \\ 15 & 3.98 & 3.01 & 3.99 & 2.99 \\ 16 & 4.05 & 2.96 & 3.63 & 2.80 \\ 17 & 4.95 & 4.12 & 4.81 & 4.11 \\ 18 & 5.84 & 5.32 & 5.77 & 5.37 \\ 19 & 6.68 & 6.57 & 6.00 & 5.99 \\ 20 & 6.31 & 6.52 & 5.64 & 5.64 \\ 21 & 5.14 & 5.22 & 5.41 & 5.19 \\ 22 & 3.95 & 4.04 & 4.63 & 4.62 \\ 23 & 3.09 & 3.13 & 3.30 & 3.35 \\ 24 & 2.48 & 2.43 & 2.51 & 2.35\end{array}$

Summer is June through October.

winter is November through May. 
Average Daily Load Shapes by Season and Day Type

Percent of Total Daily Energy

APPLIANCE CODE FROM QA=Kitchen circuit

$\begin{array}{rrrrr}\text { Hour } & \begin{array}{l}\text { Winter } \\ \text { Weekend }\end{array} & \begin{array}{l}\text { winter } \\ \text { Weekday }\end{array} & \begin{array}{c}\text { Summer } \\ \text { Weekend }\end{array} & \begin{array}{l}\text { Summer } \\ \text { Weekday }\end{array} \\ 1 & 3.72 & 3.71 & 3.85 & 3.84 \\ 2 & 3.52 & 3.50 & 3.67 & 3.63 \\ 3 & 3.36 & 3.36 & 3.52 & 3.52 \\ 4 & 3.22 & 3.25 & 3.38 & 3.40 \\ 5 & 3.20 & 3.26 & 3.33 & 3.36 \\ 6 & 3.20 & 3.41 & 3.32 & 3.48 \\ 7 & 3.40 & 3.90 & 3.46 & 3.82 \\ 8 & 3.89 & 4.31 & 3.75 & 4.04 \\ 9 & 4.24 & 4.08 & 4.09 & 3.93 \\ 10 & 4.31 & 3.91 & 4.22 & 3.88 \\ 11 & 4.21 & 3.81 & 4.13 & 3.87 \\ 12 & 4.22 & 3.85 & 4.12 & 3.90 \\ 13 & 4.28 & 4.01 & 4.23 & 4.06 \\ 14 & 4.27 & 3.92 & 4.29 & 4.03 \\ 15 & 4.26 & 3.99 & 4.31 & 4.11 \\ 16 & 4.34 & 4.21 & 4.39 & 4.31 \\ 17 & 4.55 & 4.49 & 4.60 & 4.58 \\ 18 & 5.10 & 5.21 & 4.91 & 5.02 \\ 19 & 5.28 & 5.52 & 5.08 & 5.24 \\ 20 & 5.17 & 5.40 & 5.03 & 5.19 \\ 21 & 5.05 & 5.27 & 4.91 & 5.08 \\ 22 & 4.77 & 4.96 & 4.80 & 4.92 \\ 23 & 4.42 & 4.57 & 4.52 & 4.61 \\ 24 & 4.03 & 4.11 & 4.11 & 4.16\end{array}$

Sumier is June through October. winter is November through May. 
Average Daily Load Shapes by Season and Day Type

Percent of Total Daily Energy

APPLIANCE CODE FROM QA=COOking

$\begin{array}{lllll}\text { Hour } & \text { Winter } & \text { Winter } & \text { Summer } & \text { Summer } \\ \text { Weekend } & \text { Weekday } & \text { Weekend } & \text { Weekday }\end{array}$

$\begin{array}{rrr}1 & 0.33 & 0.28 \\ 2 & 0.22 & 0.20 \\ 3 & 0.19 & 0.18 \\ 4 & 0.20 & 0.22 \\ 5 & 0.31 & 0.54 \\ 6 & 0.66 & 1.58 \\ 7 & 1.80 & 3.82 \\ 8 & 4.00 & 4.89 \\ 9 & 5.66 & 3.72 \\ 10 & 6.03 & 3.19 \\ 11 & 5.53 & 3.23 \\ 12 & 5.91 & 4.34 \\ 13 & 6.30 & 4.51 \\ 14 & 5.42 & 3.48 \\ 15 & 5.15 & 3.32 \\ 16 & 6.00 & 4.94 \\ 17 & 9.04 & 9.21 \\ 18 & 13.47 & 17.37 \\ 19 & 11.73 & 15.80 \\ 20 & 5.94 & 7.51 \\ 21 & 3.04 & 3.92 \\ 22 & 1.67 & 2.16 \\ 23 & 0.91 & 1.09 \\ 24 & 0.48 & 0.50 \\ 12 & & \end{array}$

0.38

0.27

0.23

0.24

0.37

0.70

1.67

3.69

5.67

6.21

5.86

6.03

6.13

5.10

4.71

5.33

7.84

12.29

12.32

7.12

3.95

2.20

1.08

0.59
0.33

0.24

0.22

0.27

0.56

1.57

3.45

4.38

3. 78

3.49

3.40

4.38

4.67

3.75

3.38

4.69

8.29

15.85

16.07

8.43

4.49

2.47

1.28

0.60

dre through october.

isule, is November through May. 


\section{Appendix F \\ Exploratory Analysis for CEC Space Conditioning THI-Matrix}

\section{Introduction}

In the exploratory analyses presented in this appendix we begin to address two issues of interest in forecasting residential cooling loads: (1) estimating the incremental value of additional metered data, and (2) deciding on appropriate aggregation schemes for metered load data collected across possibly disparate (in terms of characterizing load response)geographic regions and over seasons and years. Answers depend on what particular features of energy use are important (for example, the peak hour of the year or the load pattern on a typical summer weekday, etc.) and on the degree of accuracy or precision required, or, more practically, on the cost of increased accuracy and precision relative to benefits achieved. We address these issues within the framework of the time-temperature matrix representation of central air conditioner loads used in the CEC model. As in Chapter 5, we compare backcast load shapes to sample data to evaluate the time-temperature matrices developed in these exploratory analyses. A limitation to our analyses is that, while the ultimate evaluation of the usefulness of model inputs is their performance as a component in estimation of residential class demand, we do not have system level residential data to which to compare our sample data.

We first discuss motivations for disaggregation of the AMP central air conditioner data by region, season, and day type. We show the data suggest that disaggregation by these factors may be appropriate, and develop smoothed time-temperature matrices from regional subsets of the AMP data. We then compare these representations to those based on the full set of 1985-1989 AMP central air conditioning data. We also address the issue of the value of additional years of sample data by comparing a time-temperature matrix based on a single year of data to one based on four years of data. Finally, we comment on the strategy used to evaluate the backcasts. The analyses described in this appendix were conducted without using analysis weights (see Chapter 3 and Appendix A).

\section{Aggregation Issues}

The time-temperature matrix used for backcast comparisons in Chapter 5 was developed using all central air conditioner data reported in the 1985-1989 AMP data sets. Backcast results presented in that chapter indicate the all-regions 1985-1989 time-temperature matrix performs reasonably well, at least for Region 3, in "predicting" the sample loads from which the matrix was derived. It is likely, however, that average air conditioning demand response to a given set of weather conditions (here as measured by THI on a given hour) varies by geographic region, season, day type, and even from year to year. Thus, developing separate time-temperature matrices for relevant subsets of the sample data set - which may form the basis for future enhancements to the CEC model - could lead to better estimates of demand although at the 
expense of reduced sample size. Another advantage of computing matrices based on subsets of the data is that subset-specific matrices may be used for model cross-validation, so that the data used to evaluate model fit are different than those used to construct the time-temperature matrix. For example, one could test how well a time-temperature matrix based on Region 3 data works for predicting load shape characteristics of Region 2 sample data. We do not present results from such cross-validations.

The aggregation issue for the time-temperature matrix may be viewed as one of balancing accuracy with precision: while in general more data is better than less, combining too much data may decrease accuracy, if the data combined are too disparate. The more disaggregated sample data become, however, the less data there are within a classification; consequently precision may be lowered. For example, a matrix based on only Region 2 central air conditioner data uses metered data from only 65 residences, while over 400 central air conditioners were metered between 1985-1989 in the AMP sample as a whole.

We examined the extent to which response does vary according to region, day type, and "season" (as defined below), first by comparing load distributions for several fixed set of weather conditions according to various factor aggregations. As an illustration of the typical levels of load variation observed, in CEC Region 2 there were 44 days over the five-year sample period with THI 81 at 6 p.m., and in CEC Region 3 there were 79 such days. We computed the average central air conditioner load across the regional sample for each of the 44 (Region 2) and 79 (Region 3) hours, respectively. The mean of the Region 3 distribution is approximately $0.3 \mathrm{kWh}$ lower than the $1.7 \mathrm{kWh}$ mean load for Region 2. A statistical test confirms that the means are different $(p<0.05)$, although an issue of at least equal importance is "how much different?" We also note that the sets of hours compared are not the same hours of the year, so there may be other confounding factors. ${ }^{4}$ At these higher levels of disaggregation there are typically insufficient data to detect statistically significant differences for any but the grossest disparities.

We used the statistical technique analysis of variance (ANOVA) to make these comparisons for a broader portion of the sample, and to judge the importance of the differences. Considering only hours with THI 68 or greater (by an assumption of the CEC model, hours that contribute to air conditioning loads) and in the months April through October, we modeled regional mean central air conditioner load for a selected hour of the day (once for 4 p.m., once for 6 p.m.) as a function of THI and the first-order factors region, season, day type, and two second-order factor terms:region crossed with season, and region crossed with day type. We used only CEC Regions 2, 3, and 4, in these comparisons since only these three regions have sufficient data for reasonably reliable estimation of regional mean loads. The season factor had two values, Spring (April and May) and Summer (June through October). The day type factor had two values, Weekend and Weekday.

\footnotetext{
4 One might also compare distributions by day type and season in addition to region.
} 
Table F-1 lists coefficients and statistical significance (from an F-test) for these two ANOVAs. In the ANOVA for 6 p.m. load, the region and season were significant $(p=0.0001)$, but day type was not $(p=0.8002)$, nor were season crossed with region $(p=0.2379)$ or day type crossed with region $(p=0.4834)$. The coefficient estimates indicate that, for a given level of THI, central air conditioner demand is about $0.35 \mathrm{kWh}$ higher in the relatively mild Region 4 than in Region 2 and about $0.46 \mathrm{kWh}$ higher in Region 4 than in the warmest region, Region $3 .^{5}$ The coefficient estimates for seasonal effect suggest that for a given level of THI, central air conditioner demand is 0.185 higher in midsummer than in April and May. The ANOVA for 4 p.m. also indicated that region and season were important factors $(p=0.0001)$, and that day type was important as well $(p=0.004)$. That day type is important at $4 \mathrm{p} . \mathrm{m}$. seems reasonable, since residents are more likely to at home at 4 p.m. on weekends than at 4 p.m. on weekdays.

This evidence suggests that greater disaggregation of the sample data in the construction of time-temperature matrices may result in increased model accuracy. For example, if midsummer forecasts are of interest, on the basis of the ANOVAs discussed above it seems reasonable to construct separate matrices for each region and to exclude early season data from the construction of the matrices. That is, the ANOVAs indicate that the level of demand to a given value of THI varies according to region, day type, and season, yet the time-temperature matrix used to generate normalized load curves is developed on an energy scale and is therefore influenced by the levels of absolute demand for loads contributing to its development.

To provide an indication of how much different the region-specific matrices are from an all-regions matrix, we computed separate time-temperature matrices (including the smoothing procedure described in Chapter 5) for the three CEC Regions with the most metered data for central air conditioners: Region 2 (Sacramento weather station, 65 residences reporting metered central air conditioner data), Region 3 (Fresno weather station, 186 residences), and the relatively mild Region 4 (San Jose weather station, 133 residences). We compared the actual region-specific matrices to the all-region matrix, and then compared backcasts based on each region-specific matrix to backcasts based on the all-regions matrix.

Figure F-1 shows the difference between the all-regions matrix and the matrix developed for Region 2 only. Only cells for which some data were observed over the five-year period are depicted. The surface is not flat; that is, the regional matrix does not represent a constant shift of loads. This lack of flatness suggests that the normalized load shapes generated from the two matrices will differ. The matrices are in good agreement for mild weather, with differences near zero for THI less than 70 , but differ considerably for cells involving little data or with extrapolated loads.

We compared the performance of the region-specific time-temperature matrix relative to the all-regions time-tcmperature matrix. As in Chapter 5, we developed backcast load shapes for each day and compared the backcasts to the observed average load shapes from the sample data

\footnotetext{
5 That residents respond to relative changes in THI is not surprising, although these effects might be at least in part due to how representative weather at the weather station is of weather at the metered residences.
} 
in the region. For example, we compared backcasts based on the Region 2 time-temperature matrix to Region 2 sample data, using the measures described in Chapter 4. Tables F-2, F-3, and F-4 summarize the performance of the backcasts from the region-specific matrices, as compared to backcasts based on the all-region matrix, for Regions 2, 3, and 4 respectively. These summaries are based on days in the hottest five percentile of THI-DD between 1985 and 1989 at the NOAA station assigned to the region. Of course, the difficulty we noted in Chapter 5 of using the same data to develop the matrix as to evaluate the matrix is even more pronounced when using a region-specific matrix to backcast load shapes for the same region, as we do here.

Table F-2 shows that the Region 2 (Sacramento) matrix results are noticeably different than the all-regions matrix results: Region 2 matrix backcasts are worse than all-regions matrix backcasts in predicting the timing of the peak hour (17 percent correct as opposed to 23 percent correct for the all-regions backcast), but do somewhat better in predicting the level of the peak and that of the 4 p.m. load, and achieve a slightly lower mean RMSE. Similarly, Table F-4 shows the Region 4 matrix does worse in timing but better in the other three measures than the all-regions matrix. Table F-3 shows little difference between the performance of Region 3 and all-regions matrices. Note that Region 3 data makes a relatively large contribution to the all regions matrix, since it has the hottest weather and the most central air conditioners metered.

In summary, the ANOVAs described above indicate that central air conditioner load at a given hour depend not only on THI but also on region, season, and sometimes day type, and our backcast comparisons suggest that these differences may be large enough to warrant using region-specific time-temperature matrices within CEC modeling framework. However we cannot quantify the forecasting improvement that may be achieved.

\section{Value of Additional Years of Data}

Another issue in collecting metered end-use load data is estimating the value of additional data, both in terms of increased sample size and in the length of the period over which metered data is collected. In our exploratory analyses we begin to address the latter issue, again within the framework of the CEC model for residential air conditioning. In particular, we compared a time-temperature matrix developed from a single year (1988) of data alone to a matrix developed from four years of data (1985-1988) and compared backcasts from each of these two matrices to the sample data for 1989. Thus, sample data for the testing the matrices were not used in the development of the matrices, although most of the central air conditioners metered in 1989 were also metered in earlier years (that is, the 1989 sample is not "independent" of the 1985-1988 sample). We selected 1989 as the test year since it is the most recent year of sample data we have available, and selected 1988 for development of the one-year data set since it is the year closest to 1989 . More importantly, 1988 was a relatively hot year in the service territory, while 1989 was a relatively mild year; this difference in weather may affect results. 
Figure F-2 shows the difference between the time-temperature matrix developed from 1988 data only and that developed from 1985-1988 data. Again, only time-temperature cells for which some data were observed are depicted. The matrices are in close agreement for low and moderate THI portions of the matrix, but in poorer agreement in the high THI portion of the matrix, where less data are observed.

We developed backcasts for 1989 from the 1988 and from the 1985-1988 time-temperature matrices. Tables F-5 and F-6 summarize the results of the backcast-to-sample comparisons for Region 2, for all summer days and for days in the hottest ten percentile of THI-DD, respectively. (Both matrices are based on data from all regions, but separate backcasts are developed for Regions 2, 3, and 4 based on weather reported at the regional NOAA weather stations.) Definitions used for these summaries are discussed in Chapter 4. Over all summer days (Table F-5), the 1985-1988 matrix performs somewhat better than the 1988 matrix in predicting the level of load shape peaks in the 1989 Region 2 data, with the 1988 matrix generally underestimating the level of the peak. A similar but more moderate pattern holds for the hottest days (Table F-6). There is little difference between the performance of 1985-1988 and 1988 matrices for the other measures summarized in Tables F-5 and F-6.

Tables F-7 and F-8 summarize backcast results from using the 1988 and 1985-1988 matrices to predict 1989 load shapes for Region 3 for all summer days (Table F-7) and the hottest days (Table F-8). The 1985-1988 matrix predicts peak leads better than does the 1988 matrix for both all summer days and the hottest days. Both matrices predict 4 p.m. load on the hottest days well.

Tables F-9 and F-10 summarize backcasts from the 1985-1988 matrices for 1989 Region 4. While the 1985-1988 matrix does considerable better than the 1988 matrix in predicting peak loads over all summer days (Table F-9), the 1988 matrix in general predicts peak load better than does the 1985-1988 matrix for the hottest days (Table F-10).

Our analyses do not provide a general test of the question "how well does a matrix developed from any one year of data perform as compared to a matrix developed from multiple years of data?", due to the possible influence of confounding factors (which could be present in any pair of matrices compared). Among these confounding factors are the possibility of temporal trends and possible differences in response to a given set of weather variables between mild years (1989) and hot years (1988). Even with such factors, studies similar to these analyses may be useful in determining when to stop metering.

In summary, the four-year matrix predicted the level of the Region 2 sample data load shape peak better than did the one-year matrix, and both matrices performed about equally well for the other measures. That more data works better than less, assuming uniform data quality, is not a surprising result. That the performance difference betweeil the four-year and one-year matrix lies almost entirely in predicting peak level suggests specifying more precisely the items to be forecast, and the implications of that choice for accuracy in forecasting other items. Finally, on the basis of these exploratory analyses, we do not have enough information to 
estimate the extent to which accuracy in forecasting systemwide residential cooling loads can be improved by additional years of data. For example, the degree to which additional data yields improved forecasts also depends on the method used to develop the smoothed load surface: a good smoothing algorithm might make up for a sparsely filled raw data matrix.

\section{Comments on the Representation of Air Conditioning Loads}

In Chapter 5, we commented on some shortcomings of the backcast-to-sample format used for matrix evaluation. We noted that, for a given set of weather conditions, the sample data shows considerable variation. Below we briefly address this inherent sample variability and the implications this variability has for our evaluation scheme.

As an illustration of the variation over which the averaging to compute a time-temperature matrix has taken place, consider all days over the five year period in CEC Region 2 weather data THI 81 at 6 p.m. There were 44 such days. For these 44 days, average daily central air conditioner energy use in the region ranged from $0.65 \mathrm{kWh}$ to $1.93 \mathrm{kWh}$, which represents nearly a three-fold variation in load for the identical (in terms of model inputs) conditions.

To examine this variation from another perspective, we selected several days with similar THI profiles and compared the sample load shapes for these days. For example, we selected the 1986 system peak day (7/31/86, a Thursday), determined the hourly CEC Region 2 (Sacramento) THI profile for that day, and then examined historical weather data to find a second day with a similar load profile ( $9 / 5 / 88$, a Monday) with THI profile from 3 p.m. to 9 p.m. identical to that recorded for $7 / 31 / 86$. Figure F-3 shows the sample load profiles for this comparison on an energy-normalized basis. On an energy scale, the sample load shapes have nearly identical peak load levels $(2.87 \mathrm{kWh}$ at 7 p.m. on $7 / 31 / 86,2.84 \mathrm{kWh}$ at $5 \mathrm{p} . \mathrm{m}$. on $9 / 5 / 88$.) The two Region 2 energy-normalized load shapes shown in the figure are dramatically different, with peak load hour accounting for over 14 percent of total daily load on 7/31/86 but only 10.5 percent of total daily load, and two hours earlier, for $9 / 5 / 88$. Since the THI profiles for the two days are nearly the same, so would be the backcast load shapes from a time-temperature matrix; the model can not capture this sample variability. Thus, in our backcast summaries, we consider average performance rather than performance for any single day. We examined such matched pairs for each of the five system peak days, all of which showed notable differences, although somewhat less dramatically than the energy-normalized comparison described above.

In the CEC model, load data for all days contribute to the raw time-temperature matrix and hence influence the smoothed load surface. Furthermore, the contribution of a day's load shape to the matrix backcast load shape for a day with the same THI profile is not straightforward, although data for all days are used in constructing the matrix, forecasting loads for particular days (such as hottest or peak load days) or forecasting particular aspects of the load shape (such as the peak hour of the day) have historically been of most interest. This distinction is important, since peak demand is different in nature than average demand. Statistical theory reflects this: peak loads are extreme values, which as statistical entities, do not have the nice 
properties of other distributional parameters such as the mean and other moments. For these reasons, it may be appropriate to examine additional or alternative load representations to the time-temperature matrix.

\section{Conclusion}

These exploratory analyses indicate that time-temperature matrices developed from data disaggregated data according to region, day type, and season, may provide better load forecasts than a single time-temperature matrix derived from all data combined. However, our results on the value of additional years of sample data, while consistent with the expectation that more data works better than less, do not provide a complete basis upon which to estimate the value of such additional data. 


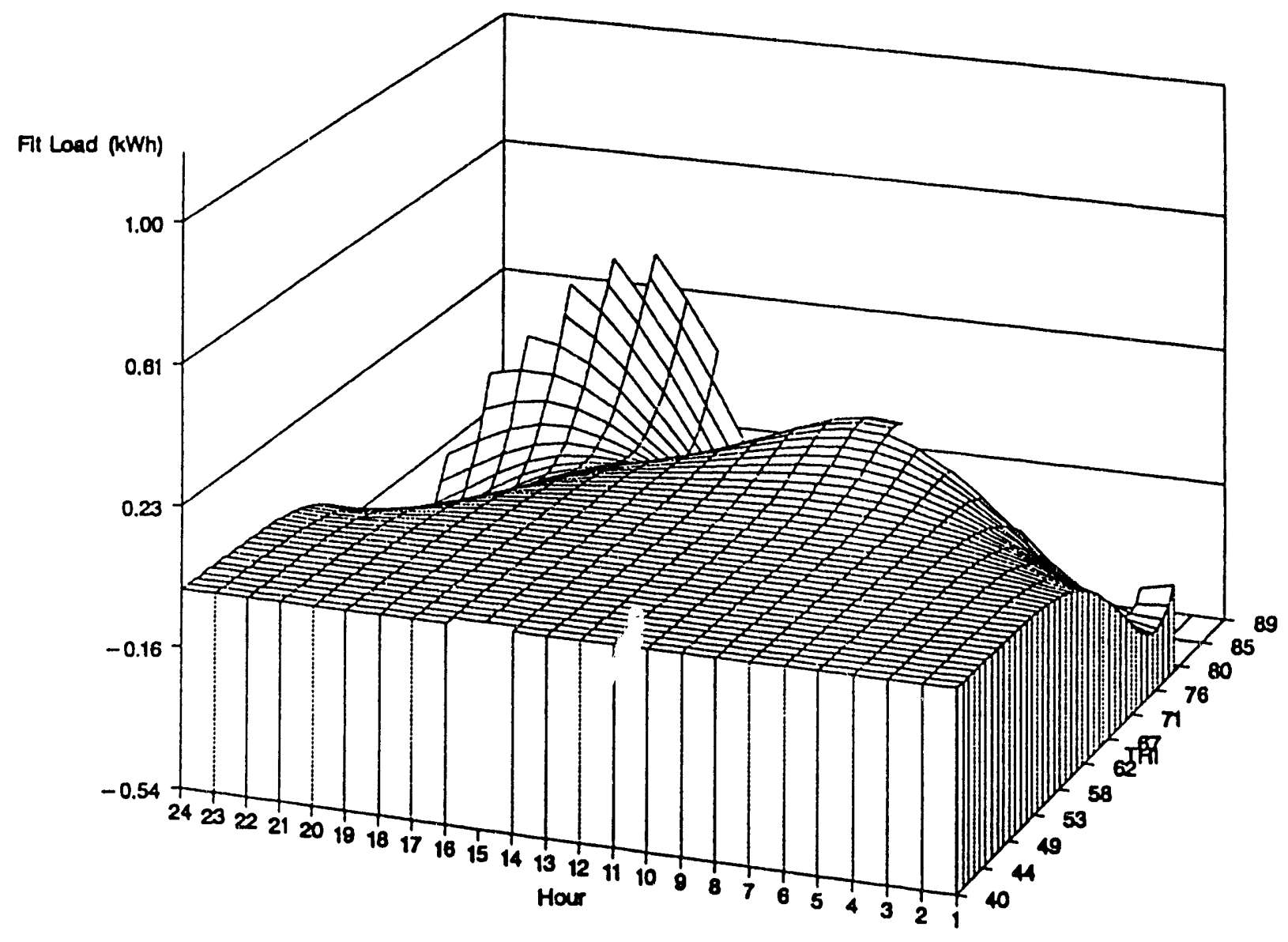

Figure F-1

Difference Between All Regions Time-Temperature Matrix and Region 2 TimeTemperature Matrix 


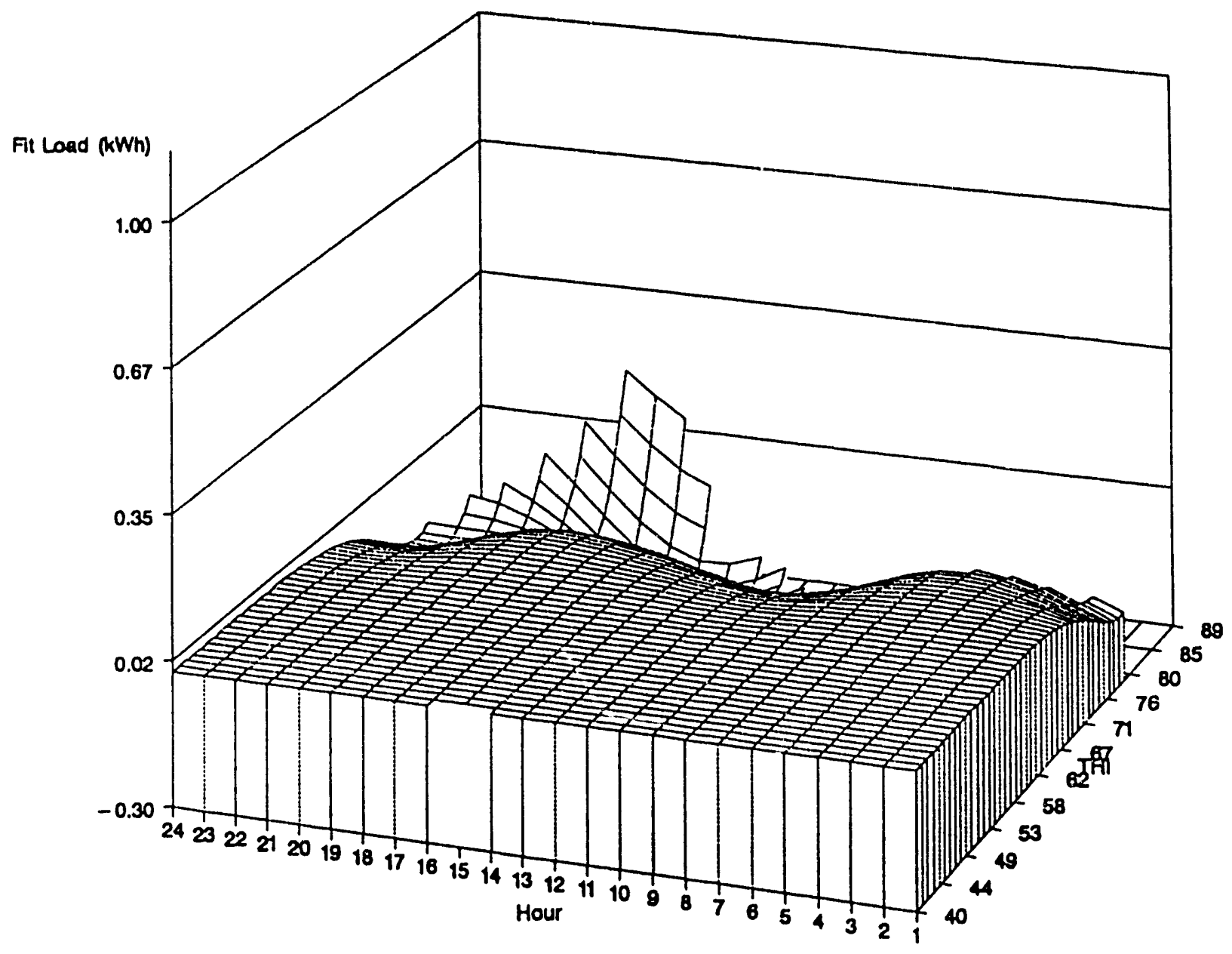

Figure F-2

Difference Between 1985-1988 Time-Temperature Matrix and 1988 TimeTemperature Matrix 


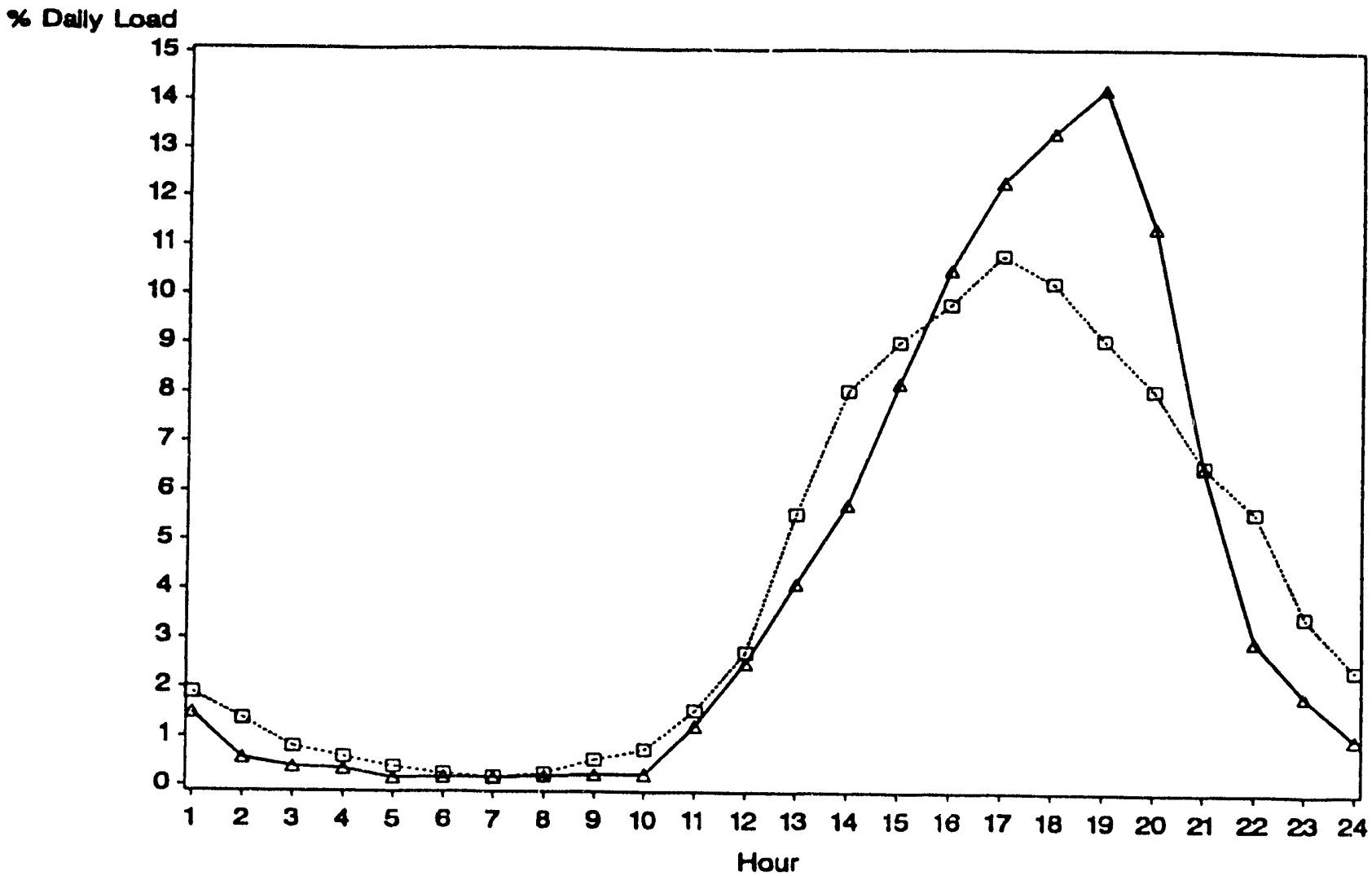

Figure F-3

CEC Region 2 Average Load Profiles for 7/31/86 (solid line) and 9/5/88 (dotted line) 
Table F-1

ANOVA Results for 4 p.m. and 6 p.m. Regional Mean Loads

ANOVA for 4 p.m. Load

\begin{tabular}{|c|c|c|c|c|c|c|}
\hline Paramoter * & Estiruate & $\begin{array}{c}\text { Stendard } \\
\text { Error }\end{array}$ & p-value* & Estimate & $\begin{array}{l}\text { Standard } \\
\text { Error }\end{array}$ & p-value* \\
\hline Intercept & -8.51 & 0.12 & 0 & -10.33 & 0.13 & 0 \\
\hline THI & 0.12 & 0 & 0 & 0.15 & 0 & 0 \\
\hline $\begin{array}{l}\text { CEC Region } \\
2 \\
3 \\
4\end{array}$ & $\begin{array}{r}-0.21 \\
-0.27 \\
0\end{array}$ & $\begin{array}{r}0.03 \\
0.03 \\
n / a\end{array}$ & $\begin{array}{r}0.0001 \\
0.0001 \\
0.00 .11 \\
\text { n/a }\end{array}$ & $\begin{array}{r}-0.33 \\
-0.46 \\
0\end{array}$ & $\begin{array}{r}0.04 \\
0.04 \\
n / a\end{array}$ & $\begin{array}{r}0.0001 \\
0.0001 \\
0.0001 \\
n / a\end{array}$ \\
\hline $\begin{array}{l}\text { Season } \\
\text { Spring } \\
\text { Summer }\end{array}$ & $\begin{array}{r}-0.09 \\
0\end{array}$ & $\begin{array}{r}0.03 \\
n / a\end{array}$ & $\begin{array}{r}0.0001 \\
0.0066 \\
\mathrm{n} / \mathrm{a}\end{array}$ & $\begin{array}{r}-0.18 \\
0\end{array}$ & $\begin{array}{r}0.04 \\
n / a\end{array}$ & $\begin{array}{r}0.0001 \\
0.0001 \\
n / a\end{array}$ \\
\hline $\begin{array}{l}\text { Day Type } \\
\text { Weekday } \\
\text { Weekend }\end{array}$ & $\begin{array}{r}-0.02 \\
0\end{array}$ & $\begin{array}{r}0.03 \\
n / a\end{array}$ & $\begin{array}{r}0.0041 \\
0.0289 \\
n / a\end{array}$ & $\begin{array}{r}0.02 \\
0\end{array}$ & $\begin{array}{r}0.03 \\
n / a\end{array}$ & $\begin{array}{r}0.8002 \\
0.4848 \\
n / a\end{array}$ \\
\hline $\begin{array}{l}\text { Season } \times \text { Region } \\
\text { Spring } \times \text { Region } 2 \\
\text { Spring } \times \text { Region } 3 \\
\text { Spring } \times \text { Region } 4 \\
\text { Summer } \times \text { Region } 2 \\
\text { Summer } \times \text { Region } 3 \\
\text { Summer } \times \text { Region } 4\end{array}$ & $\begin{array}{r}0.05 \\
-0.01 \\
0 \\
0 \\
0 \\
0\end{array}$ & $\begin{array}{r}0.04 \\
0.04 \\
n / a \\
n / a \\
n / a \\
n / a\end{array}$ & $\begin{array}{r}0.2150 \\
0.2115 \\
0.8554 \\
\mathrm{n} / \mathrm{a} \\
\mathrm{n} / \mathrm{a} \\
\mathrm{n} / \mathrm{a} \\
\mathrm{n} / \mathrm{a}\end{array}$ & $\begin{array}{r}0.09 \\
0.05 \\
0 \\
0 \\
0 \\
0\end{array}$ & $\begin{array}{r}0.05 \\
0.05 \\
n / a \\
n / a \\
n / a \\
n / a\end{array}$ & $\begin{array}{r}0.2379 \\
0.0921 \\
0.3494 \\
\mathrm{n} / \mathrm{a} \\
\mathrm{n} / \mathrm{a} \\
\mathrm{n} / \mathrm{a} \\
\mathrm{n} / \mathrm{a}\end{array}$ \\
\hline $\begin{array}{l}\text { Daytype } \times \text { Region } \\
\text { Weekend } \times \text { Region } 2 \\
\text { Weekend } \times \text { Region } 3 \\
\text { Weekend } \times \text { Region } 4 \\
\text { Weekday } \times \text { Region } 2 \\
\text { Weekday } \times \text { Region } 3 \\
\text { Weekday } \times \text { Region } 4\end{array}$ & $\begin{array}{r}0 \\
-0.05 \\
0 \\
0 \\
0 \\
0\end{array}$ & $\begin{array}{r}0.04 \\
0.04 \\
n / a \\
n / a \\
n / a \\
n / a\end{array}$ & $\begin{array}{r}0.2909 \\
0.9473 \\
0.1876 \\
\mathrm{n} / \mathrm{a} \\
\mathrm{n} / \mathrm{a} \\
\mathrm{n} / \mathrm{a} \\
\mathrm{n} / \mathrm{a}\end{array}$ & $\begin{array}{r}0 \\
-0.04 \\
0 \\
0 \\
0 \\
0\end{array}$ & $\begin{array}{r}0.04 \\
0.04 \\
n / a \\
n / a \\
n / a \\
n / a\end{array}$ & $\begin{array}{r}0.4834 \\
0.9125 \\
0.3022 \\
n / a \\
n / a \\
n / a \\
n / a\end{array}$ \\
\hline
\end{tabular}

- p-values are from F-test for factors (THI, CEC Region, Season, Day TYpo, Season x Region, and Daytype x Region) and from t-test for coefficiont estimates.

- the dimensionality of the factor subspaces requires model constraints: coefficients for some levels of each factor are set to 0 , with corresponding stendard orror estimates and p-values irrolevant. Coofficients for the other lovels of the factor show relative offects. This practice is called aliasing, and does not affect the model itself, but only model expression. 
Table F-2

Summary of Backcast Performance of All-Regions and Region-Specific Matrix for CEC Region 2

Days in Top 5 Percent of THI-DD

Timing of Pask Hour

\% same $\ldots \ldots \ldots \ldots \ldots \ldots \ldots \ldots \ldots \ldots \ldots$

\% 1 hour late .....................

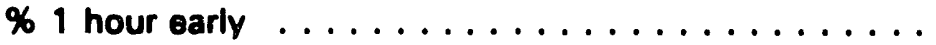

$\%>2$ hours off

$\begin{array}{cc}\text { All Region } & \begin{array}{c}\text { Region } 2 \\ \text { Matrix }\end{array} \\ \text { Matrix } \\ 23 & 17 \\ 28 & 15 \\ 32 & 34 \\ 4 & 8\end{array}$

Magnitude of Paek (samplo-backcast)

Normalized:

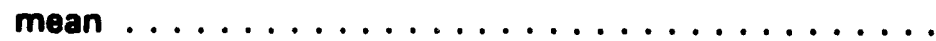

mean absolute .....................

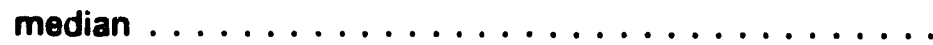

standard deviation

$-0.022$

$-0.008$

0.022

$-0.020$

0.011

0.013

$-0.006$

0.013

Magnitude of 4 p.m. Lasd (sample-backeast)

Normalized:

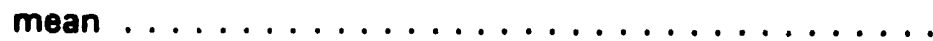

mean absolute ....................

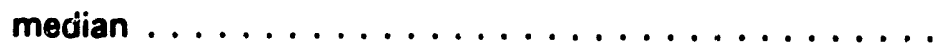

standard deviation

$-0.014$

$-0.016$

0.017

0.018

$-0.014$

$-0.016$

0.015

0.014

RMSE

Normalized:

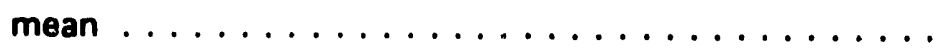

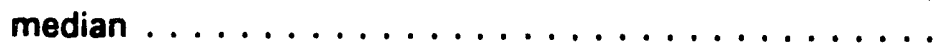

standard deviation

0.013

0.010

0.013

0.010

0.003

0.003

Number of day pairs

47

47

backcast rolativo to samplo ". in terms of THI-DD (see text) 
Table F-3

Summary of Backcast Performance of All-Regions and Region-Specific Matrix for CEC Region 3

Summer Days in Top 5 Percent of THI-DD

Timing of Pask Hour

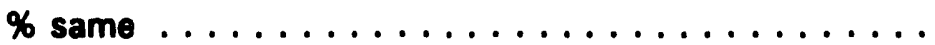

\% 1 hour late $\ldots \ldots \ldots \ldots \ldots \ldots \ldots \ldots \ldots$

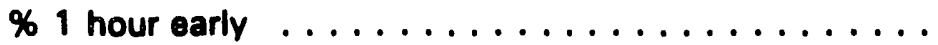

$\%>2$ hours off

Magnitude of Peak (samplo-backcast)

Normalized:

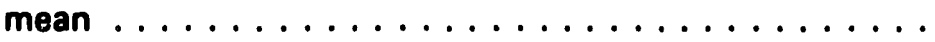

mean absolute $\ldots \ldots \ldots \ldots \ldots \ldots \ldots \ldots$

median . . . . . . . . . . . . . . . .

standard deviation $\ldots \ldots \ldots \ldots \ldots \ldots \ldots$

Magnitude of 4 p.m. Load (samplo-backcast)

Normalized:

mean $\ldots \ldots \ldots \ldots \ldots \ldots \ldots \ldots \ldots \ldots \ldots$

mean absolute $\ldots \ldots \ldots \ldots \ldots \ldots \ldots \ldots \ldots$

median . . . . . . . . . . . . . . . . . .

standard deviation

RMSE

Normalized:

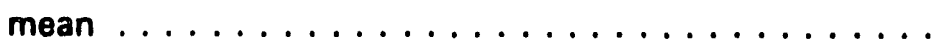

$\operatorname{median} \ldots \ldots \ldots \ldots \ldots \ldots \ldots \ldots \ldots$

standard deviation

Number of day pairs

$\begin{array}{cc}\begin{array}{c}\text { All Rogion } \\ \text { Matrix }\end{array} & \begin{array}{c}\text { Region 3 } \\ \text { Matrix }\end{array} \\ 27 & 27 \\ 25 & 25 \\ 23 & 25 \\ 10 & 8\end{array}$

$-0.001 \quad-0.004$

$0.006 \quad 0.007$

$0.002 \quad-0.004$

$0.008 \quad 0.007$

$\begin{array}{lr}0.001 & -0.001 \\ 0.006 & 0.007 \\ 0.001 & -0.001 \\ 0.008 & 0.008\end{array}$

$0.007 \quad 0.007$

$0.006 \quad 0.007$

$0.002 \quad 0.002$

48

48

backcest rolative to sample " in torms of THI-DD (see text) 
Table F-4

Summary of Backcast Performance of All-Regions and Region-Specific Matrix for CEC Region 4

\section{Days in Top 5 Percent of THI-DD}

Timing of Peak Hour

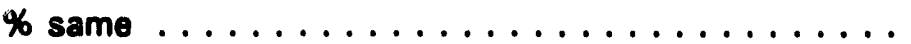

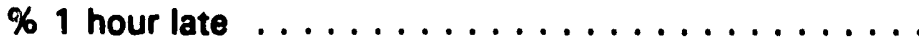

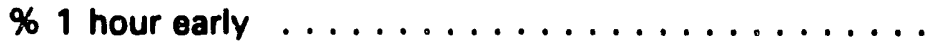

$\%>2$ hours off $\ldots \ldots \ldots \ldots \ldots \ldots \ldots \ldots \ldots$

Magnitude of Pask (samplo-backcast)

Normalized:

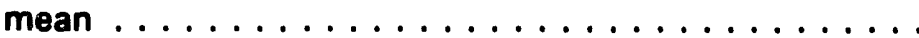

mean absolute ....................

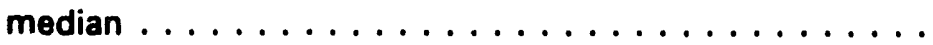

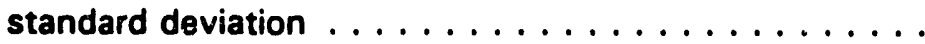

Magnitude of 4 p.m. Laad (samplo-backcast)

Normalized:

$\operatorname{mean} \ldots \ldots \ldots \ldots \ldots \ldots \ldots \ldots \ldots \ldots \ldots$

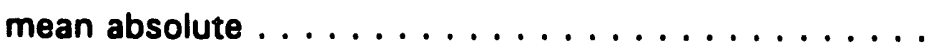

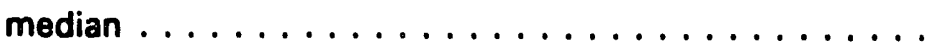

standard deviation

$\begin{array}{cc}\text { All Region } & \begin{array}{c}\text { Region 4 } \\ \text { Matrix }\end{array} \\ \text { Matrix } \\ 30 & 18 \\ 10 & 25 \\ 40 & 38 \\ 3 & 0\end{array}$

$\begin{array}{rr}-0.016 & 0.000 \\ 0.021 & 0.013 \\ -0.018 & 0.002 \\ 0.021 & 0.018\end{array}$

$-0.020 \quad-0.006$

$0.022 \quad 0.012$

$-0.018 \quad-0.006$

$0.018 \quad 0.015$

RMSE

Normalized:

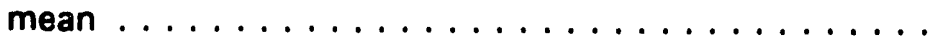

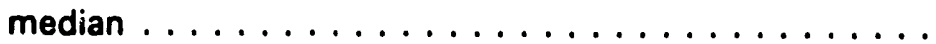

standard deviation

0.014

0.011

0.014

0.010

0.004

0.003

Number of day pairs 
Table F-5

Summary of Backcast Performance of 1988 and 1985-1988 Matrices for CEC Region 2

\section{Summer Days}

Timing of Peak Hour

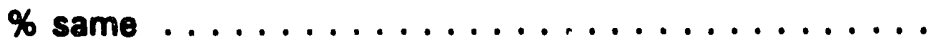

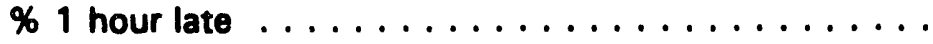

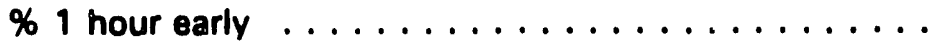

$\%>2$ hours off

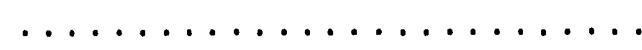

Magnitude of Paak (samplo-backcast)

Normalized:

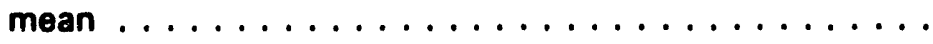

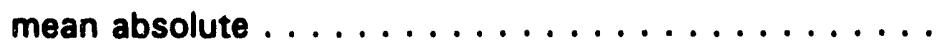

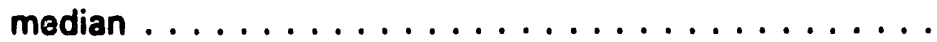

standard deviation

$\begin{array}{cc}\begin{array}{c}1985-1988 \\ \text { Matrix }\end{array} & \begin{array}{c}1988 \\ \text { Matrix }\end{array} \\ 27 & 28 \\ 17 & 16 \\ 23 & 24 \\ 18 & 19\end{array}$

Magnitude of 4 p.m. Losd (sample-backcast)

Normalized:

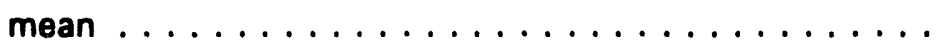

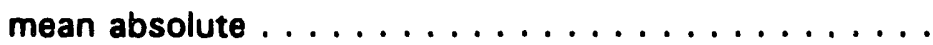

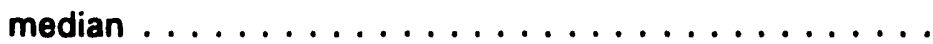

standard deviation

$\begin{array}{rr}-0.001 & 0.014 \\ 0.037 & 0.038 \\ 0.002 & 0.014 \\ 0.052 & 0.049\end{array}$

RMSE

Normalized:

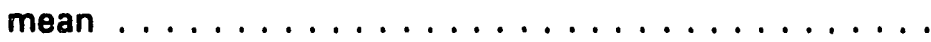

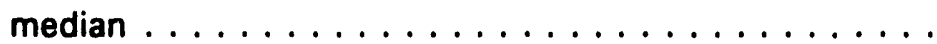

standard deviation

0.030

0.029

0.023

0.025

$0.017 \quad 0.015$

Number of day pairs 
Table F-6

Summary of Backcast Performance of 1988 and 1985-1988 Matrices for CEC

Region 2

1989 Summer Days in Top 10\% of 1989 THI-DD

Timing of Pask Howr

\% same $\ldots \ldots \ldots \ldots \ldots \ldots \ldots \ldots \ldots \ldots \ldots$

$\% 1$ hour late

\% 1 hour early

$\%>2$ hours off

\begin{tabular}{|c|}
\hline $\begin{array}{c}1985-1988 \\
\text { Matrix } \\
21 \\
32 \\
26 \\
0\end{array}$ \\
\hline
\end{tabular}

Magnitudo of Poak (samplo-backcast)

Normalized:

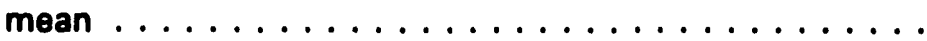

mean absolute $\ldots \ldots \ldots \ldots \ldots \ldots \ldots \ldots$

median . . . . . . . . . . . . . . . . .

standard deviation

$\begin{array}{rr}-0.003 & 0.006 \\ 0.018 & 0.018 \\ -0.006 & 0.002 \\ 0.023 & 0.023\end{array}$

$-0.002$

$-0.002$

0.018

$-0.006$

0.022

0.017

$-0.005$

0.021

RMSE

Normalized:

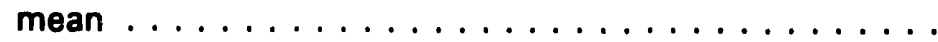

median . . . . . . . . . . . . . . .

standard deviation

0.013

0.014

0.012

0.012

$0.004 \quad 0.005$

Number of day pairs 
Table F-7

Summary of Backcast Performance of 1988 and 1985-1988 Matrices for CEC

Region 3

1989 Summer Days

Timing of Pask Hour

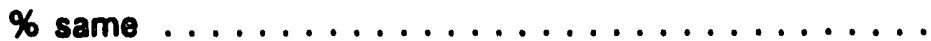

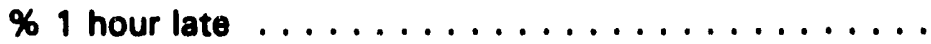

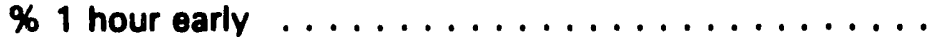

$\%>2$ hours off $\ldots \ldots \ldots \ldots \ldots \ldots \ldots \ldots \ldots \ldots$

Magnitude of Peak (sample-backcast)

Normalized:

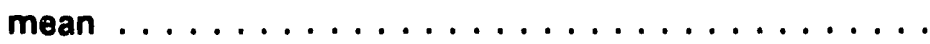

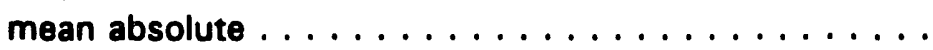

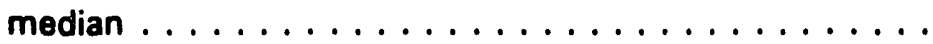

standard deviation

$\begin{array}{cc}\begin{array}{c}1985-1988 \\ \text { Maưrix }\end{array} & \begin{array}{c}1988 \\ \text { Matrix }\end{array} \\ 35 & 41 \\ 21 & 19 \\ 21 & 21 \\ 14 & 14\end{array}$

Magnitude of 4 p.m. Load (sample-backcast)

Normalized:

$\operatorname{mean} \ldots \ldots \ldots \ldots \ldots \ldots \ldots \ldots \ldots \ldots$

$-0.012-0.003$

mean absolute ....................

0.023

0.018

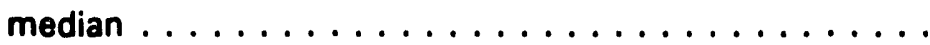

$-0.008$

0.002

standard deviation

0.030

0.025

RMSE

Normalized:

$\operatorname{mean} \ldots \ldots \ldots \ldots \ldots \ldots \ldots \ldots \ldots$

$0.021 \quad 0.028$

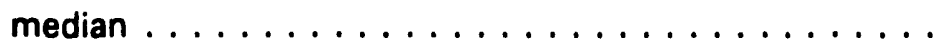

$0.015 \quad 0.018$

standard deviation $\ldots \ldots \ldots \ldots \ldots \ldots$

$0.017 \quad 0.023$

Number of day pairs . . . . . . . . . . . . . . . . . . . 184 
Table F-8

Summary of Backcast Performance of 1988 and 1985-1988 Matrices for CEC Region 3

1989 Summer Days in Top 10\% of 1989 THI-DD

Timing of Pask Hour

\% same $\ldots \ldots \ldots \ldots \ldots \ldots \ldots \ldots \ldots \ldots \ldots \ldots$

\% 1 hour late

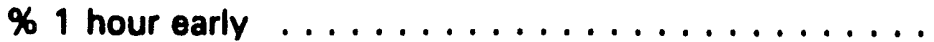

$\%>2$ hours off

$\begin{array}{cc}\begin{array}{c}1985-1988 \\ \text { Matrix }\end{array} & \begin{array}{c}1988 \\ \text { Matrix }\end{array} \\ 41 & 41 \\ 18 & 18 \\ 27 & 32 \\ 0 & 0\end{array}$

Magnitude of Paak (sample-backcast)

Normalized:

$\operatorname{moan} \ldots \ldots \ldots \ldots \ldots \ldots \ldots \ldots \ldots \ldots$

mean absolute $\ldots \ldots \ldots \ldots \ldots \ldots \ldots \ldots$

median . . . . . . . . . . . . . . . . .

standard deviation

Magnitude of 4 p.m. Load (samplo-backcast)

Normalized: mean $\ldots \ldots \ldots \ldots \ldots \ldots \ldots \ldots \ldots \ldots \ldots$

mean absolute $\ldots \ldots \ldots \ldots \ldots \ldots \ldots \ldots \ldots$

$\operatorname{median} \ldots \ldots \ldots \ldots \ldots \ldots \ldots \ldots \ldots \ldots$

standard deviation

$\begin{array}{ll}0.000 & 0.000 \\ 0.007 & 0.007 \\ 0.001 & 0.000 \\ 0.009 & 0.009\end{array}$

RMSE

Normalized:

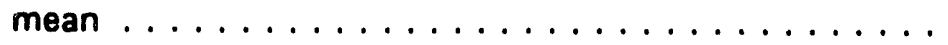

median . . . . . . . . . . . . . . . .

standard deviation

Number of day pairs.
0.007

0.007

0.001

22

backcast rolative to semplo in torms of THI-DD (se0 text) 
Table F-9

Summary of Backcast Performance of 1988 and 1985-1988 Matrices for CEC Region 4

\section{Summer Days}

Timing of Peak Hour

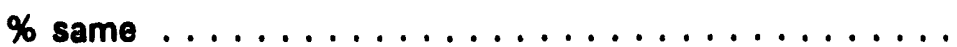

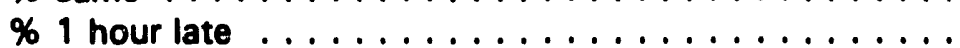

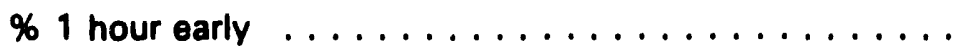

$\%>2$ hours off

$\begin{array}{cc}1985-1988 & 1988 \\ \text { Matrix } & \text { Matrix } \\ 25 & 29 \\ 17 & 21 \\ 29 & 23 \\ 16 & 16\end{array}$

Magnitude of Pask (samplo-backcast)

Normalized:

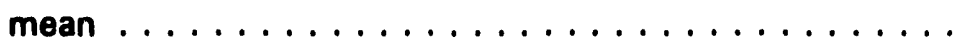

$0.001 \quad-0.030$

mean absolute $\ldots \ldots \ldots \ldots \ldots \ldots \ldots \ldots \ldots \ldots$

0.029

0.049

median . . . . . . . . . . . . . . . . . .

$0.003 \quad-0.003$

standard deviation

0.040

0.073

Magnitude of 4 p.m. Load (sample-backcast)

Normalized:

$\begin{array}{lrr}\text { mean } \ldots \ldots \ldots \ldots \ldots \ldots \ldots \ldots & -0.019 & -0.003 \\ \text { mean absolute } \ldots \ldots \ldots \ldots \ldots \ldots \ldots \ldots \ldots \ldots \ldots \ldots \ldots \ldots & 0.023 & 0.024 \\ \text { median } \ldots \ldots \ldots \ldots \ldots \ldots \ldots \ldots \ldots \ldots \ldots \ldots \ldots & -0.018 & -0.001 \\ \text { standard deviation } \ldots \ldots \ldots \ldots \ldots \ldots \ldots \ldots \ldots \ldots \ldots \ldots \ldots & 0.032 & 0.033\end{array}$

RMSE

Normalized:

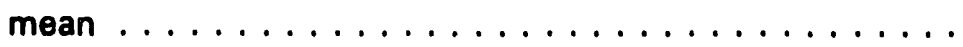

median . . . . . . . . . . . . . . . . .

0.026

0.032

standard deviation

0.022

0.015

0.024

Number of day pairs 
Table F-10

Summary of Backcast Performance of 1988 and 1985-1988 Matrices for CEC Region 4

1989 Summer Days in Top 10\% of 1989 THI-DD

Timing of Pask Hour

\% same

\% 1 hour late

\% 1 hour early

$\%>2$ hours off

$\begin{array}{cc}\begin{array}{c}1985-1988 \\ \text { Matrix }\end{array} & \begin{array}{c}1988 \\ \text { Matrix }\end{array} \\ 30 & 25 \\ 15 & 15 \\ 40 & 40 \\ 0 & 0\end{array}$

Magnitudo of Peak (samplo-backcast)

Normalized:

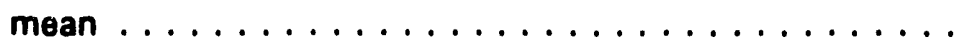

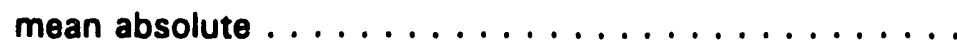

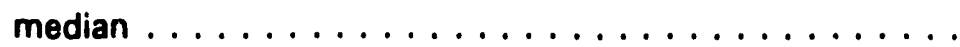

standard deviation

$-0.009$

0.018

$-0.009$

0.023

0.001

0.016

0.003

0.023

Magnitude of 4 p.m. Load (samp/e-backcast)

Normalized:

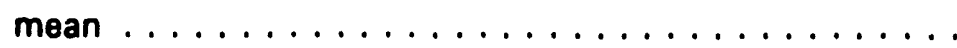

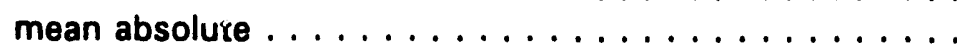

median ........................

standard deviation
$-0.010$

0.018

$-0.013$

0.018
$-0.007$

0.017

$-0.011$

0.018

RMSE

Normalized:

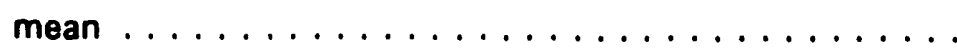

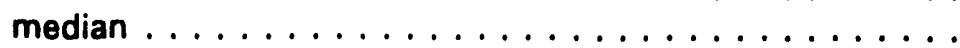

standard deviation

0.015

0.017

0.015

0.018

0.004

0.005

Number of day pairs 

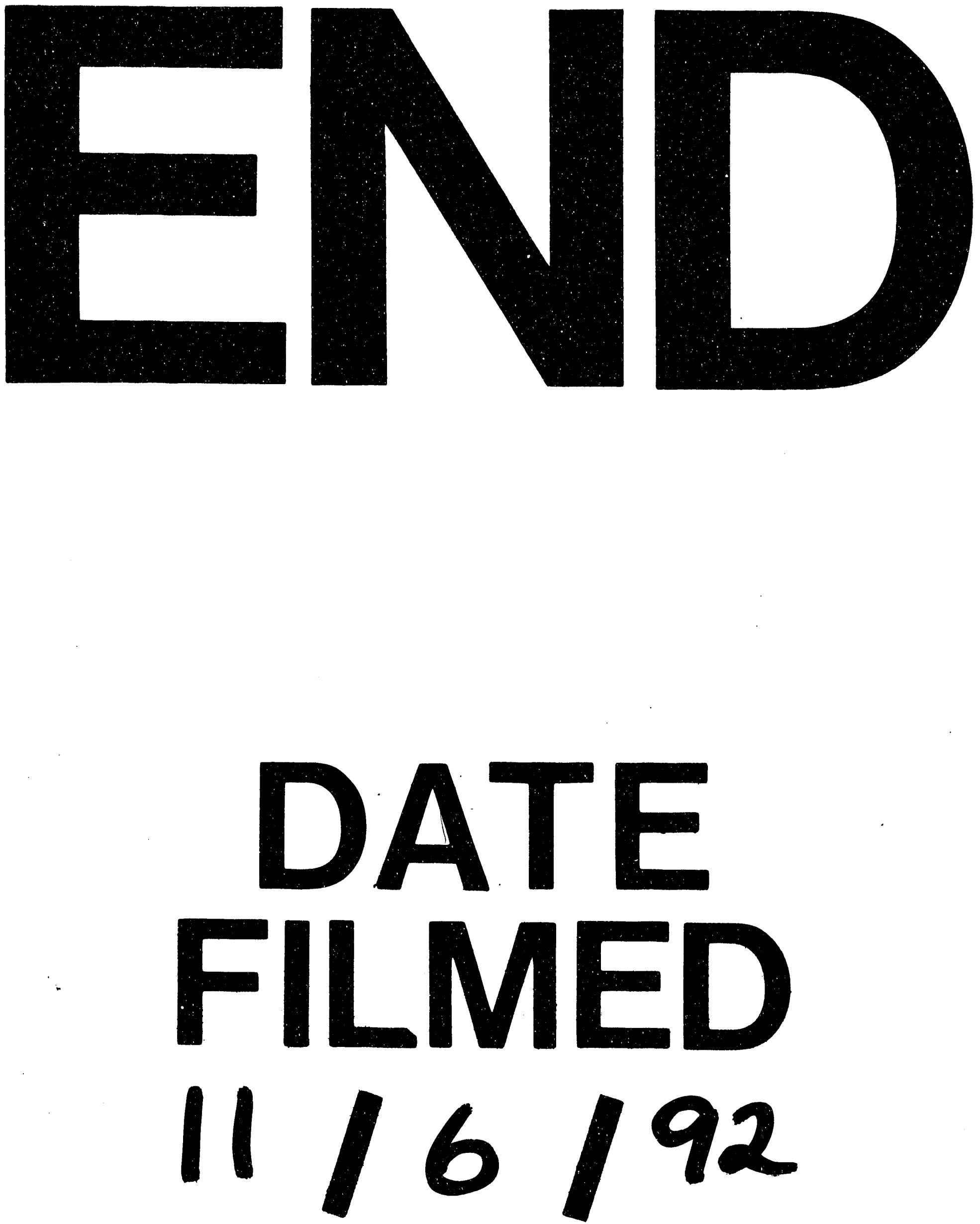

1 
